\title{
The Viability
}

of Human Security

Monica den Boer \& Jaap de Wilde (eds.)

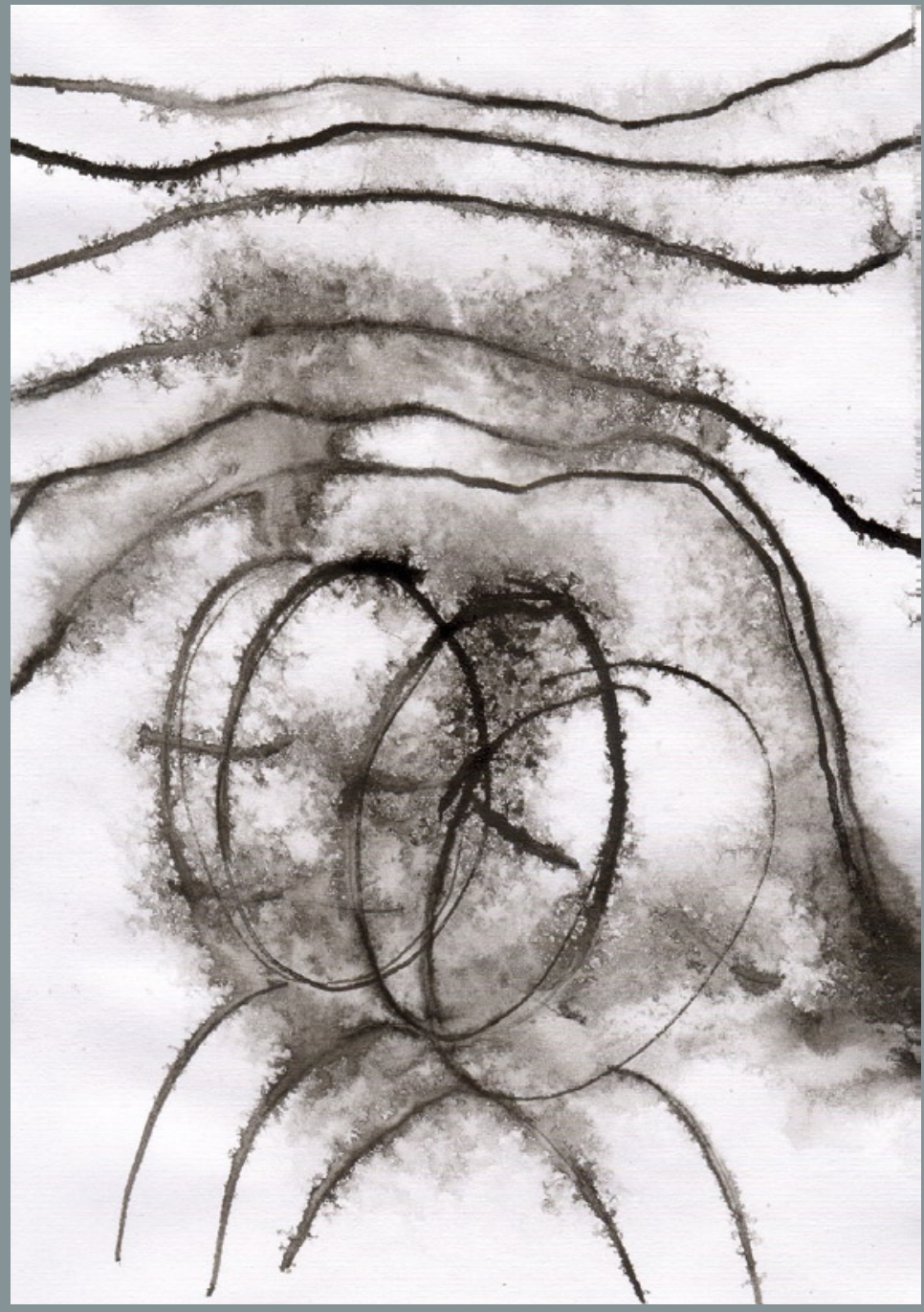


The Viability of Human Security 



\section{The Viability of Human Security}

Monica den Boer and Jaap de Wilde (eds.) 
Cover: Geert de Koning, Ten Post

Cover drawing: D. Oudshoorn

Lay-out: Adriaan de Jonge, Amsterdam

ISBN 9789053567968

NUR 74I

(C) Monica den Boer and Jaap de Wilde / Amsterdam University Press, Amsterdam, 2008

All rights reserved. Without limiting the rights under copyright reserved above, no part of this book may be reproduced, stored in or introduced into a retrieval system, or transmitted, in any form or by any means (electronic, mechanical, photocopying, recording or otherwise) without the written permission of both the copyright owner and the author of the book. 


\section{Table of Contents}

I Introduction

1 Top-Down and Bottom-Up Approaches to Human Security 9 Monica den Boer and Jaap de Wilde

II Top-Down Human Security Policies

$2 \quad$ From Just War to Just Peace 21

Mary Kaldor

3 Failing Global Justice and Human Security 47

Willy Bruggeman

4 Governing Transnational Law Enforcement in the EU:

Accountability after Fusing Internal and External Security 71

Monica den Boer

5 The Lack of Coherence between Internal and External Security

Policies of the European Union 97

Cyrille Fijnaut

6 Ambidextrous Military:

Coping with Contradictions of New Security Policies 109

Joseph L. Soeters

III Human Security Policies from Below

7 Human Security, the Military and the (Israeli) State:

'In-Between Organisations' at Checkpoints 127

Eyal Ben-Ari 
8 Human Security from Below:

Freedom from Fear and Lifeline Operations 149

Mient Jan Faber

9 Human Security from Below:

Palestinian Citizens Protection Strategies, 1988-2005 179 Walid Salem

10 Human Security from Below:

Local Security Networks in the Netherlands 203

Jan Terpstra

IV Conclusion

$11 \quad$ Speaking or Doing Human Security? 225

Jaap de Wilde

About the Authors 255

Index $\mathbf{2 5 7}$ 


\section{PART I}

Introduction 



\title{
1 Top-Down and Bottom-Up Approaches to Human Security
}

\author{
Monica den Boer and Jaap de Wilde
}

It is incredible how 'national states' structure the mind - not just the minds of academics who study state sovereignty and national identity, and not just the minds of politicians whose actions are simultaneously shaped and constrained by state and nation - but the mind of every individual or group willing and able to be political. People in most parts of the world are so state- and ethnocentric. Despite globalisation, every newspaper has separate pages for domestic and foreign news. Even the pages about globalised economics work with distinctions such as local, national, regional and world markets. We are inclined to think in terms of internal and external. We have learned to value the lives of domestic individuals differently than the lives of foreign individuals. Even though most violence occurs in private settings, we love those close to us more than people we have never met. And we have found ways to define who is in the inner circle: In addition to family ties, nationalism, ideological 'isms', myths about ethnicity, and religions shape collective identities that set 'us' apart from 'them', creating gaps between our close ones and the remote ones, the 'others' - even if they live next door. The human security discourse intends to break this spell. But can it? Can its conceptual universal'ism' be translated into practical policies that overcome the statecentric and ethnocentric 'isms' that so far have helped to shape and execute security policies worldwide? This book shows some remarkable forms of local human security policies (called human security from below), that have not yet been discussed in the wider literature on the subject. This book further elaborates the ongoing debate about top-down initiatives to transform traditional state security policies into human security policies. 
The human security discourse as such dates back to the Human Development Report 1994 published by the United Nations Development Programme ( UNDP), subtitled: New Dimensions of Human Security. A year later the Commission on Global Governance (I995) elaborated the distinction between the security of states and the security of peoples (see also Lodgaard, 2004). The UN and its institutions have often been successful 'trendsetters' in international discourse in the past, and over the years, the term 'human security' has achieved a status close to concepts such as 'sustainability' (coined by the World Commission on Environment and Development (WCED) in I987) and 'good governance' (coined by the World Bank in I989). In some countries human security has led to reforms in military strategy (particularly in Canada and Norway), while in other countries it has yet to even trigger a public debate [in the Netherlands, for example, so far only a few articles in the journal Vrede \& Veiligheid and two books (Muller and De Gaay Fortman, 2004; Frerks and Klein Goldewijk, 2007) have appeared on the subject]. We think it should stir more discussion.

Both in theory and in practice, the concept of human security indicates a shift in the main referent object of security. It is no longer the state we are concerned about (national or state security), nor traditional warfare (military security). Security has to be about humanity at every level, on every scale: individuals, (small) groups, and the global population. Security has to be focused on 'freedom from want and freedom from fear', as it was originally described in the I 994 UNDP report, and on 'the freedom of future generations to inherit a healthy environment,' as UN Secretary-General Kofi Annan (200I) added. 'Human security can no longer be understood in purely military terms. Rather, it must encompass economic development, social justice, environmental protection, democratisation, disarmament, and respect for human rights and the rule of law' (Annan, 2005). Is the shift inevitable? Do we have to change the way we study security concerns? Is the shift desirable? Do we want to change the way we practise security policies? It is important to find out whether human security will be a political buzzword or a paradigm shift in the global approach to conflict management. If the concept takes root, there are implications for international law (see chapters 2 and 3 ), for policy making and strategic thinking for the military and the police (chapters 4-6), and for reinterpreting security initiatives by existentially threatened local groups of people in conflict-ridden circumstances 
(chapters 7-IO). Last but not least, there are implications for the way we study security (chapter I I).

We analyse human security from two perspectives: its quality as a concept in Security Studies (its theoretical value), and its quality as a policy device (its practical value). Opinions about its theoretical value depend on one's understanding of the international system. Have the combined effects of globalisation and the end of the Cold War rendered the traditional distinction between internal and external security agendas obsolete to such an extent that traditional security agendas have lost their meaning? Advocates of the concept argue that state-centric analyses of 'international' security fall short of understanding the contemporary dynamics of existential threats. Sceptics argue that the sovereign state nevertheless remains the focus of attention: states or intergovernmental organisations, like the United Nations, are requested to adapt their policies. In contrast with this (often implicit) top-down approach, various chapters in this volume explore non-governmental human security policies. It can be hypothesised that these practices are symptoms of government failure or of government retraction in situations where the neo-liberal state imposes a strategy of 'responsibilisation': apparently, people have to take care of themselves in order to survive. If the scope and frequency of these initiatives increase, it can be hypothesised that structural change is taking place indeed.

This so-called 'bottom-up' approach (referred to as 'human security from below') also provides examples of human security as a policy device, implying a redirection of traditional security policies. Opinions about its value as a policy device depend on one's general position on the role of the military, the police and intelligence forces in society. Can we 'humanise' coercive power? Can we effectively intervene in failed or repressive states on behalf of the suffering population? The human security discourse expresses the urge to focus security policies on people rather than on institutions. Advocates of the concept argue that peacekeeping, peace enforcement and peacebuilding cannot be successful without a human security perspective. Sceptics argue that contemporary politics overestimates the margins for change, which brings human security policies into the sphere of either utopianism or traditional power politics in disguise. 


\section{The Barcelona Report}

In parts II and III of this book, existing insights in human security are refined especially by elaborating on strategies for human security from below, and discussing operational consequences for the military and police of switching from state to human security. Part II discusses the top-down context of applying human security policies. Mary Kaldor (chapter 2) opens the debate by building further on her work for the Study Group on Europe's Security Capabilities. In 2003 this international team of experts, chaired by Kaldor, presented the Barcelona Report: A Human Security Doctrine for Europe: Report of the Barcelona Study Group on Europe's Security Capabilities (referred to hereafter as the Barcelona Report). The report was written in the context of the European Security and Defence Policy (ESPD) of the EU and includes recommendations to the EU's High Representative for the Common Foreign and Security Policy (CFSP), Javier Solana.

One of the interesting aspects of the Barcelona Report is that it highlights the operational consequences of adopting a human security policy. It was well timed: in a period when the EU wants to create a military potential of its own (the ESPD) chances for institutional design are optimal. Moreover, news of the scandals of the Us military in Iraq (the torture and other in the Abu Ghraib prison in April and May 2004; the repeated random killings of civilians and rapes by US soldiers reported in May-July 2006 by, among others, The Washington Post) show that soldiers tend to be ill-equipped and wrongly trained for peace-building activities. Problems like these are not limited to us soldiers: Canadian soldiers seriously misbehaved in Somalia in 1993 (analysed well in a broader context by Razack (2004)), and in April 2005, Secretary-General Kofi Annan's special adviser on sexual exploitation and abuse by un peacekeepers, Prince Zeid Ra'ad Al-Hussein, recommended a range of measures to improve group discipline and individual responsibility of both military and civilian peacekeepers. ${ }^{\mathrm{I}}$ The mere need for such a special adviser is itself an indicator of the problems.

The Barcelona Report pleads in favour of a human security doctrine that consists of seven operational measures: 'the primacy of human rights, clear political authority, multilateralism, a bottom-up approach, regional focus, the use of legal instruments, and the appropriate use of force' (Barcelona Report, 2003: 5 ). In chapter 2, Kaldor 
elaborates in particular the international legal and ethical context. Accepting a human security perspective has had a major impact on the classic distinction between military and civilians, and on views about the right to wage war (jus ad bellum) and rights and obligations during war (jus in bello). The role of the military needs to be organised more in line with how the police are organised in societies. In practice, police and military work gets blurred in various ways, while the human security approach also implies closer civil-military (CIMIC) cooperation. Therefore, the rights and duties of the military have to be defined in terms of peacetime logic rather than the logic of exceptional wartime circumstances (which normally implies suspension of various civil and human rights).

In line with this goal, Willy Bruggeman (chapter 3 ) discusses the options for using human security policies to enhance the role of the International Criminal Court, as well as other legal instruments to curb aggressive interpretations of traditional state security. By emphasising how (the combat of) terrorism and organised crime are intertwined, he strengthens Kaldor's case by suggesting we stop looking at wartime as a condition clearly distinct from peacetime and start recognising the need to merge criminal law with jus in bello. Monica den Boer (chapter 4 ) links this debate to the already ongoing fusion between internal and external security within the EU. This fusion implies a redefinition of the roles (and hence training and armament) of the military, the police and intelligence services. These changes in the division of labour between defence and security organisations and law and order organisations again point to the blurring of traditional distinctions between extraordinary and normal politics. This demands not merely new operational policies, but also a new system of democratic checks and balances to guard this process. Cyrille Fijnaut (chapter 5) emphasises the impotence of sticking to traditional security notions. By analysing the European Security Strategy report (2003), he reveals the political stalemate rooted in nationalism and traditional sovereignty concerns that still dominates the attempts to merge internal and external security policies into a coherent whole. Through these chapters, we lower the level of abstraction from legal principles to policy practices, to finally arrive at the level of practical implementation.

To achieve the operational objectives, the Barcelona Report suggests the creation of a Human Security Response Force 'composed of I 5,000 men and women, of whom at least one-third would be civil- 
ian (police, human rights monitors, development and humanitarian specialists, administrators, etcetera) ...' (Barcelona Report, 2003: 5). 'Dedicated' troops need to be accompanied by 'civilian capabilities'. These capabilities are hardly specified, but include 'police, court officials, prosecutors and judges' (Barcelona Report, 2003: 19), 'police, tax and customs officers, judges, administrators, providers of aid and human rights specialists' (Barcelona Report, 2003: 2I). The 'dedication' of the troops requires a 'considerable cultural shift for the military and civilians,' the Barcelona Report (2003: 23) says. The traditional military spirit should be combined with the 'civilian spirit of listening, individual responsibility, empathy and enabling others; respect for and knowledge of law ...; awareness of gender dimensions of conflict and intervention' (Barcelona Report, 2003: 2I).

Joseph Soeters (chapter 6) addresses the difficulties of creating such a team spirit. Both the multilateral nature of deployment (the difficulty to integrate forces from different armies) and the contradictory demands of the operations (how to distinguish the needy civilian from the suicide bomber?) require what he calls 'ambidextrous behaviour'. The growing number of studies on civilian-military cooperation (CIMIC) also show how much needs to be done before troops are sufficiently skilful to meet the requirements of the Human Security Doctrine (Holm \& Eide, 2000; Winslow, 2002; Brocades Zaalberg, 2005; Rietjens, 2006).

Nevertheless, the learning process in humanitarian interventions, peacekeeping and peace-building spans a mere decade. Experience in the context of the UN is growing (from I945 to I990 the UN organised I 8 peacekeeping operations; during the I990s they organised 34 missions; Bellamy, Williams and Griffin, 2004: 276-279) and many European states take part in that process. Some states already deploy human security policies, notably Norway and Canada who, in I998, set up the Human Security Network. ${ }^{2}$ Such think-tanks are pivotal in the construction of a global 'epistemic community' that promotes both the study and the practice of issues raised by the human security debate. Among the achievements of the Network is the development of the Human Security Index (HSI), which it hopes will compete with the Human Development Index (HDI) and, probably with more success, traditional state-centric indexes like national economic growth figures or gross national products.

The EU may try to follow their example, and is in a special position to adopt a human security policy. As analysed in the chapters by Den 
Boer (chapter 4) and Fijnaut (chapter 5), the quasi-domestic realm of the EU forces the governments of its member states to merge traditional foreign policy concerns (focused on state security in mainly or ultimately military terms) with Europeanisation of domestic security policies (focused on a combination of state and human security in terms of law enforcement by police, the judiciary and penitentiary systems). Den Boer discusses the consequences for the governance of policing within the EU.

In fact, the Third Pillar of the Eu, which concerns Police and Judicial Cooperation in Criminal Matters (PJCC) as well as the broader range of Justice and Home Affairs (JHA), is more relevant for its immediate security concerns than the Second Pillar about the CFSP and the ESPD. Including the EUFOR mission on Bosnia Herzegovina, the Second Pillar focuses mainly on interventions in conflicts out of area (also NATO's main operational focus is out of area, i.e., on the soil of non-member states). The difficulties of establishing European police cooperation while guaranteeing checks and balances on the results provide a test ground for the kind of difficulties the 'smart manpower' (Barcelona Report, 2003: 23) of a human security response force may encounter in the countries it has to police. Especially when the presence of a third party will be long term (as can be expected, e.g., of EUFOR's presence in Bosnia Herzegovina and NATO's presence in Afghanistan) the 'third' party becomes part of the society where it works and lives. The quality of relationships with the local population and civil society then becomes crucial. Hence, internal Eu developments may help to evaluate the global developments towards human security operations.

\section{Security for the People by the People}

Part II highlights the role of society in human security policies. The incentives come from the NGO sphere: the world of non-governmental non-profit organisations and networks, often called civil society, which work transnationally with or without the consent of governments, and essentially beyond their control, just like their commercial counterparts, transnational corporations (TNCs). Part II I discusses various practices of human security initiatives at the local level.

In cases of a failing government or a repressive government, the public sector has lost its protective functions. A retracting govern- 
ment runs the same risk. In the absence of a well-functioning public sector, people have no choice but to create self-help structures to provide them with a minimum of protection. In the chapters by Mient Jan Faber, Walid Salem, Jan Terpstra and Eyal Ben-Ari, practices of such policies are explored. Faber (chapter 8 ) discusses various examples of lifeline operations in failed states. Ben-Ari (chapter 7) and Salem (chapter 9) analyse similar initiatives in the context of the repressive states. Human security from below in these circumstances is about resistance and liberation, or about making day-to-day life more bearable. But self-support initiatives occur in well-established democracies as well, as is exemplified by Terpstra's discussion of local security networks in the Netherlands (chapter Io). His analysis of how to successfully set up local security networks, in which the role of the police organisation remains vital, raises fundamental questions about accountability and transparency. Most human security studies disregard these problems because they focus from a Western perspective on failed or repressive states in the rest of the world. But because of the context sketched in part I of this volume - the need to incorporate the human security logic as a part of peacetime conditions too - it works as an eye-opener to apply the same logic to Western societies. In the context of democratic societies we almost automatically will consider doubts about accountability, legitimacy and transparency when local groups of people start to practise their own local security policies, especially when it involves the use of violence. Why not raise these issues in the democracies-to-be: should self-support initiatives in democracies be judged differently than those in the context of failed or repressive states? Should third-party interventions escape the logic of accountability towards the society where they occur? In other words, Terpstra's concerns about self-help initiatives in the Dutch context are extremely relevant for self-initiatives described in the context of the Israel-Palestine conflict, Iraq and Bosnia.

An interesting consequence of theorising human security is how to interpret these examples of human security from below. Are bottomup initiatives symptoms of government failure or retraction (too repressive, too chaotic or too lax)? Or are these initiatives logical corollaries of network societies? In other words, do they originate from the policy level (a debate about 'good governance') or do they originate in structural changes of world politics? These questions are dealt with in the concluding chapter by Jaap de Wilde. 
Throughout parts II and III of the book the interaction between top-down and bottom-up human security policies is at stake: a successful human security policy needs roots in society as well as thirdparty support. However local a conflict may be, it is always embedded in regional and often global contexts. 'Outside' actors within these structures have a choice to determine their level of direct involvement, but cannot escape their responsibility to at least make up their minds. Kaldor (chapter 2) therefore concludes that a 'just peace theory' is needed to replace the logic of 'Just War theory' in order to remind these actors of their responsibility, and to operationalise human security into concrete hardware and software for the military and the police. In the concluding chapter, De Wilde (chapter I I) argues that this only makes sense if the concept of human security achieves universal application analogous to the concept of human rights.

\section{Notes}

I www.un.org/apps/news/printnewsAr.asp?nid=I3874.

2 www.humansecuritynetwork.org; see also: Canadian Consortium on Human Security, www.humansecurity.info.

\section{References}

Annan, Kofi A. (200I), "Foreword”, in: McRae and Hubert, 200I: xix.

Annan, Kofi A. (2005), Towards a Culture of Peace: Letters to Future Generations, http://www.unesco.org/opiz/lettres/TextAnglais/AnnanE.html.

(Barcelona Report) Study Group on Europe's Security Capabilities (2003), A Human Security Doctrine for Europe: Report of the Barcelona Study Group on Europe's Security Capabilities, Barcelona, September I 5, 2003, available online: http://www.lse.ac.uk/Depts/global/Publications/HumanSecurityDoctrine.pdf; also published in: Glasius, Marlies and Mary Kaldor, Eds. (2006), A Human Security Doctrine for Europe: Project, Principles, Practicalities, London: Routledge, pp. 327-356.

Bellamy, Alex J., Paul Williams and Stuart Griffin (2004), Understanding Peacekeeping, Oxford: Polity Press.

Brocades Zaalberg, Thijs (2005), Soldiers and Civil Power: Supporting or Substituting Civil Authorities in Peace Operations, Amsterdam: Amsterdam University Press. 
Commission on Global Governance, Our Global Neighbourhood: The Report of the Commission of Global Governance, Oxford: Oxford University Press, I995.

European Security Strategy: A Secure Europe in a Better World, Adopted by the Council of European Union, I 2 December 2003, http://ue.eu.int.

Frerks, Georg and Berma Klein Goldewijk, Eds. (2007), Human Security and International Insecurity, Wageningen: Wageningen Academic Publishers.

Holm, Tor Tanke and Espen Barth Eide, Eds. (2000), Peacebuilding and Police Reform, London: Frank Cass.

Lodgaard, Sverre (2004), “Human Security: Concept and Operation” in: Muller and De Gaay Fortman 2004: I6-38.

McRae, Rob and Don Huberts, Eds. (200I), Human Security and the New Diplomacy: Protecting People, Promoting Peace, Montreal: McGill Queen's University Press.

Muller, Marie and Bas de Gaay Fortman, Eds. (2004), From Warfare to Welfare: Human Security in a Southern African Context, Assen: Royal Van Gorcum.

Razack, Sherene (2004), Dark Threats \& White Knights: The Somalia Affair, Peacekeeping, and the New Imperialism, Toronto: University of Toronto Press.

Rietjens, Bas (2006), Civil-Military Cooperation in Response to a Complex Emergency: Just Another Drill?, Enschede: University of Twente.

UNDP - United Nations Development Programme (1994), Human Development Report I994: New Dimensions of Human Security, UN PD: http://hdr.undp.org/reports/global/I994/en/.

WCED (World Commission on Environment and Development), Our Common Future, Oxford: Oxford University Press, 1987.

Winslow, Donna (2002), "Strange Bedfellows: NG Os and the Military in $\mathrm{Hu}$ manitarian Crisis”, International Journal of Peace Studies, Vol. 7, No. 2, pp. 35-55.

World Bank (1989), Sub-Saharan Africa: From Crisis to Sustainable Growth, Washington: World Bank. 


\section{PART II}

\section{Top-Down Human Security Policies}





\title{
2 From Just War to Just Peace
}

\author{
Mary Kaldor
}

'In one of its modes, Just War theory would also abolish war by the (theoretically) simple method of calling unjust wars "crimes" and Just Wars "police actions". We have here a nice example of what the Chinese call "the rectification of names", but it presupposes in practice a thoroughgoing transformation of international society.' (Walzer, I992: XXII)

In this chapter, I argue that just such a thoroughgoing transformation in international society is taking place even though it does not amount to the establishment of a global state, which is what Walzer implied. Just War theory is increasingly stretched and difficult to apply in the context of those changes we lump together under the rubric of globalisation. These include growing consciousness of humanity as a single community, growing awareness that the destructiveness of war is unacceptable, increased interconnectedness in all fields, growing importance of human rights norms and laws, and above all, new forms of overlapping political authority often described as global governance involving states, international institutions, as well as civil society and, indeed, individuals. I will argue that a new ethical approach is needed, grounded in the notion that the rights of individuals supersede the rights of states and that, therefore, international law that applies to individuals overrides the laws of war. In other words, jus in pace should not be suspended in wartime in favour of jus ad bellum or jus in bello.

There is still a role for legitimate military force, but the way it is used is more akin to domestic law enforcement than war-fighting. I 
use the term 'human security' to refer to the defence of individuals as opposed to 'state security'. Of course some of the principles of Just War theory are relevant to law enforcement, as is much of the content of humanitarian law, but a change in the language is important. Just War theory does offer a framework for thinking about the justifiable use of force but that is different from Just War. In particular, crucial differences with Just War theory are the reconceptualisation of aggression as a violation of human rights, the shift in the authorisation of force from the national state to a multilateral set of arrangements, and a rejection of notions like 'collateral damage', 'proportionality', 'double effect' or 'unintentionality'.

In developing this argument, I will start by describing the changes in warfare and global governance that have resulted from the process known as globalisation and then consider the implications for Just War theory. I will end by setting out the key principles of a human security approach - a new jus in pace.

\section{The Changing Character of Warfare}

In the twentieth century, military technology became more destructive, more accurate and more widely available. Some I 5 million people died in World War I and some 55 million in World War II. ${ }^{\mathrm{I}}$ Around half a million civilians died from allied bombing in Germany alone. A million died in the siege of Leningrad. Symmetric war, war between two similarly armed opponents, has become too destructive to be fought. The importance of nuclear deterrence in the post-World War II period can be understood as a metaphor for the destructiveness of war in general. This does not mean that such wars will never again take place. The war between Iraq and Iran in the I980s was just such a war - millions of young men died in trenches rather similar to World War I and the war ended in a stalemate. (We often forget this trauma and the role of our governments in sustaining that war when we discuss Iraq and Iran in 2005-2008.) There are widespread concerns about the possibility of such wars in East Asia, as a consequence of, say, a Chinese attack on Taiwan or a North Korean attack on Japan.

The destructiveness of symmetric war leads to a growing unacceptability of war in general. This happened already after World War I. The notion that war is a legitimate way for states to pursue their in- 
terests that held sway in the post-Westphalian period, was rejected in the Charter of the League of Nations, in the Kellogg-Briand pact of I928, and, above all, in the aftermath of World War II when the crime of aggression was enshrined in the Nuremberg and Tokyo tribunals and in the Charter of the United Nations. As with human rights norms and rules, these prohibitions have been strengthened by civil society pressure, in particular the growth of peace movements, especially in the advanced industrial world.

In other words, the growing destructiveness of war and the growing unacceptability of war mean that states no longer have the option of using war as a policy instrument and therefore have to deal with each other in different ways. Of course, it can be argued that the United States (or China) is an exception to this principle. Clearly, the Bush Administration, like all governments, does still regard military power as a policy instrument. But Iraq may turn out to be the exception that proves the rule. The main lessons from the war in Iraq may well include the difficulty of using the military instrument, that superiority of military technology does not bring decisive victories, and that legitimacy is more important than force.

The destructiveness and unacceptability of wars between states or symmetric warfare do not mean an end to war. But the new types of war are asymmetric, that is to say violence is primarily directed against unarmed and unprotected civilians rather than against other warring parties; in other words, the increasing use of terror. What I call 'new wars' are wars that have evolved from guerrilla warfare and 'low-intensity wars' as ways of getting around concentrations of conventional force. The warring parties try to control territory politically through fear rather than through militarily attacking an enemy. These wars involve a mixture of warfare (political violence), human rights violations and violations of the laws of war (violence against non-combatants, genocide, massacres, torture and atrocities, mass rape) and ordinary crime (looting, pillaging, smuggling, and other illegal forms of war finance). They involve state and non-state actors and they blur classic distinctions between combatant and non-combatant, competent political authority and lack of authority, international and external - all distinctions that are critical for Just War doctrine (Kaldor, I999).

It is often argued that advanced military technology is capable of much greater precision than ever before so that wars can be more proportionate and discriminate. It is true that contemporary wars 
fought by the United States make use of precision weapons that greatly reduce collateral damage in comparison with the wars of the twentieth century. Nevertheless, as I shall argue below, such damage is often relatively high in the context of 'new wars' because of the difficulty of distinguishing between combatants and non-combatants.

\section{Global Governance}

Globalisation in terms of new waves of migration, increased interconnectedness and the changing character of warfare can be said to amount to a 'thoroughgoing transformation of international society' (Walzer, I992: xxii). States remain the juridical repository of sovereignty; international institutions derive their legal foundation from treaties agreed among states. But in practice, states are hemmed in by a system of global governance, in which they remain key actors, along with international institutions, regional organisations like the European Union or the African Union, transnational corporations, NGOs and civil society and even individuals. Their capacity to act as autonomous agents is greatly circumscribed and, in particular, the recourse to war as an instrument of policy is now prohibited.

A system of global governance is not the same as a 'global state with a monopoly on the legitimate use of force' (Walzer, 2004: xiv) and indeed, such a state is probably not desirable since it would have a great potential for tyranny. But it is quite different from a world where states act as individuals pursuing their national interests to which Just War theory, at least in its post-Westphalian guise, is supposed to apply. Walzer says that the rights of states derive from the social contract within states in which individual rights are transmuted into state rights in exchange for protection against external encroachment of life and liberty at home. The 'Great Divide', as it is known in the International Relations literature (Clark, I 999), between the domestic civil society peopled by individuals, norms, law and politics, and an external state of nature peopled by states that pursue their self-interest, is an expression of this conception of the rights of states. What is happening today is that the social contract within states is being increasingly supplemented by a social contract at a global level (Held, 2004; Kaldor, 2003). Rules and laws that apply to individuals as well as states are being negotiated among the family of individuals, groups and institutions that constitute what we call global gover- 
nance. This is why it is possible to talk about a blurring of the distinction between inside and outside, domestic and external. The Great Divide has not disappeared, but it is no longer so clear-cut. The inside can no longer be insulated from an outside of terror, organised crime or ethnic and religious conflict. The outside is increasingly perceived as a world where individual as well as state rights apply and where states no longer have the same autonomy to pursue their interests. This is the context in which to rethink the applicability of the precepts of Just War.

\section{Why the Language of Just War is Awkward}

James Der Derian uses the term 'virtuous war' to describe the combination of 'virtual war', that is, war at long distance that we only experience through our television screens, and Just War. He talks about the capacity of 'virtuous war' to 'commute death', not only to keep death out of sight but also to legitimate death (Der Derian, 200I; see also Burke, 2004). There is a fine line between legitimate killing and murder, between soldiers as criminals and soldiers as heroes. Just War is about managing that fine line. This is why rules of warfare have always been so important. But it also means that Just War can be used as easily to legitimate war and evade responsibility as to elucidate what is permissible and what is not, especially in the case of long distance wars. This argument applies to both parts of Just War doctrine - jus ad bellum (the right to make war) and jus in bello (the right way to make war - restraints and limitations in war).

\section{Jus ad Bellum}

According to James Turner Johnson, cumulative Just War doctrine includes the following elements in jus ad bellum: just cause, right authority, right intention, that war does no more harm than good (ad bellum proportionality), last resort, and the purpose to achieve peace (Turner Johnson, I98I). In what follows, I focus on just cause and right authority. Nowadays, the most common just cause for using military forces is humanitarian intervention, which has been renamed by the United Nations Secretary-General's High Level Panel on Threats, Challenges and Change as the Responsibility to Protect (UN Report, 2004). This proposal, originating in the Canadian-sponsored international commission on intervention and sovereignty, 
was debated by the United Nations World Summit in September 2005. The acceptance of the concept has strengthened an emerging global social contract whereby the international community is seen to be responsible for protecting people in the event of genocide, gross violations of human rights, or crimes against humanity. The spread of 'new wars', in which violence is directed against civilians, combined with growing human consciousness, has increased the pressure not to stand by when tragedies are inflicted on innocent people.

Yet in most accounts of Just War theory, humanitarian intervention is an exception, a footnote in discussions of just cause. In the third edition of his seminal work on Just War theory, Walzer (2000: xii) says that this is the one 'large and momentous shift' that has taken place since he first wrote the book. 'The issues that I discussed under the name "interventions" which were peripheral to the main concerns of the book have moved dramatically to the centre ... [T] he chief dilemma of international politics is whether people in danger should be rescued by military forces from outside.'

In the twentieth century and in most contemporary accounts of Just War doctrine, the main just cause is self-defence in the event of external aggression. This follows from the prohibitions against war introduced as a result of the two world wars. It was not always so. St Augustine, the father of Just War theory, was primarily concerned about restoration of the moral order. In Christian teachings on Just War, the notion of neighbourly love, the protection of others, was an important element. War was necessary, according to St Augustine, in order to 'curb licentious passions by destroying those vices which should have been rooted out and suppressed by the rightful government' (quoted in Langan, I984). ${ }^{3}$ According to John Langan (I984), this 'punitive' concept of war overrides self-defence. For St Augustine, war can only be authorised by a public authority for public purposes - it is about the protection of others. Thus obedience to a rightful authority is central to his thinking and individuals, even if they reject temporal rulings, have no right to resist.

A Just War also excludes passion and revenge. Following St Augustine, medieval scholars, particularly Aquinas, viewed just cause as righting an injury or a fault caused by others. Just War was distinguished from holy war in that it was authorised by secular authorities and recognised certain in bello restraints. Holy war, by contrast, could be authorised by religious authorities and was waged against non-Christians. In the transition to modernity, scholars like Francisco 
de Vitoria and Hugo Grotius were, according to Turner Johnson ( $198 \mathrm{I}$ ), responsible for the 'dethroning of religion'. Vitoria, in particular, made the point that natural law, the law imprinted by God on our consciousness, applies to non-Christians such as American Indians. Grotius identified just cause with charity, by which he meant something akin to what nowadays we would call humanitarianism.

The idea that only secular authorities had the right to wage war and that wars of religion were anachronistic gradually evolved, after the treaties of Westphalia ( 1648 ), into the notion that wars could be fought for reasons of state. Thus war came to be regarded in the eighteenth and nineteenth centuries 'as a means - and a highly imperfect one at that - of settling disputes between two sovereigns who recognised no common judge' (Bugnion, 2002). At that time, the emphasis of Just War theory was on restraints and limitations rather than on just cause. The total wars of the twentieth century, however, called into question the legitimacy of reasons of state as well as the possibilities for limiting and restraining wars, giving rise to the current international consensus that only wars of self-defence are legitimate.

So strong is the insistence that self-defence is the only just cause and that the principle of non-intervention should not be violated, that several interventions actually undertaken for humanitarian purposes have been forced into the straitjacket of self-defence. In the Indian intervention in Bangladesh in I97I, the Indians justified their use of military force in terms of the threat of 'refugee aggression' even though, as the Indian Ambassador to the United Nations pointed out to the Security Council, what was happening in east Pakistan at that time was such as to 'shock the conscience of mankind' ${ }^{4}$ In the international intervention in northern Iraq in I99I, where the United Nations established a safe haven for the Kurds, Security Council Resolution 688 emphasised the 'threat to international peace and security' posed by refugees.

But in a world where the difference between internal and external and between state and non-state is blurred, what is the difference between aggression and humanitarian catastrophe? In theory, one is an attack by a foreign state and the other is inflicted on a people by their own state or non-state actors. But in new wars, where states are disintegrating and where the warring parties involve paramilitary groups, foreign mercenaries, mujahadeen and the like, this distinction is more difficult to apply than it would seem.

The war in Bosnia Herzegovina well illustrates these dilemmas. 
The war was fought by a combination of remnants of the Yugoslav army and territorial defence forces and para-military groups composed of local and foreign volunteers, both criminal and fanatic. Those who favoured international intervention claimed that this was a war of aggression by Serbia and Croatia against Bosnia Herzegovina. Those who were against intervention claimed this was a civil war between Serbs, Croats and Muslims. Yet the case for intervention derived surely from the rights of the victims. This was a war of ethnic cleansing, involving massacres, large-scale population displacement, detention camps, and widespread atrocities including mass rape. Did it matter whether these violations of human rights were inflicted by Serbs from Serbia or Bosnian Serbs, by regular forces or paramilitary groups, or whether Bosnia Herzegovina was an independent state or part of Yugoslavia?

The problem of how to interpret the attacks of September I I, 200I, represents an even more telling case. This was clearly an act that 'shocked the conscience of mankind'. President Bush chose to define it as an act of aggression and drew the parallel with the Japanese attack on Pearl Harbour that brought the United States into World War II. By doing so, he was able to use the phrase the Global War on Terrorism and justify the attacks on Afghanistan and Iraq.

But this was not an attack by a foreign state. It was an attack by a group of individuals. Supposing the attack has been carried out by Christian fundamentalists like Timothy McVeigh who attacked the Federal Building in Oklahoma, or Muslim fundamentalists who were also American citizens, could President Bush have declared war? As Michael Walzer put it in an article soon after September I I, the word 'war' is unobjectionable as long as those who use it understand what a metaphor is. But 'there is right now, no enemy state, no battlefield' (Walzer, 200I).

What happened on September I I was a humanitarian catastrophe. It could be described, and many chose to describe it in these terms, as a 'crime against humanity'. The implication of this description is that the attackers were criminals rather than enemies; they could have been any nationality. In such a horrendous crime, there might well be a case for military action in a foreign country to apprehend the criminals, but the nature of that action would be different from war.

Why do terms matter? There are two key differences between war and humanitarian intervention. One has to do with right authority and the other concerns the way military force is used. In medieval 
times, bellum, the use of force for public ends, was distinguished from duellum, the use of force for private ends. Just War theory spelled out the criteria for justifying the use of force for public ends the use of force for private ends was considered illegitimate. Only secular authorities, who knew no temporal superior, could declare war.

Nowadays, it is national wars that are becoming illegitimate. $\mathrm{Na}$ tional interest can be considered a sort of private interest as opposed to the global public interest. The important distinction, nowadays, is between the use of force for humanitarian ends and the use of force for national ends. Both President Bush and Prime Minister Blair insisted that their concern was humanitarian rather than national. But if the concern is humanitarian, it cannot be authorised unilaterally by a government that represents a particular group of citizens, it requires some multilateral authority. According to Article 2.7 of the United Nations Charter, states can unilaterally authorise the use of force in self-defence in the event of foreign aggression. But all other legitimate uses of military force, including humanitarian intervention, can only be authorised by the United Nations Security Council under Chapter VII of the Charter. This needs to be augmented by a set of rules that allow for situations where the Security Council is blocked, but the principle of multilateral authorisation for all uses of military force other than self-defence is critical.

\section{Jus in Bello}

The second difference between war and humanitarian intervention has to do with means. Just War theory and its codification in international law in the second half of the nineteenth century applied to states. In the Middle Ages, Just War was fought among European princes and other political authorities; it did not apply to internal violence or to wars against non-Christians such as the Crusades. James Turner Johnson (I98I) describes several instances where internal rebellions were put down with great brutality, apparently with the approval of theologians of Just War. Thus, for example, Luther approved of the suppression of the German peasant rebellion in the sixteenth century, on the grounds of right authority, even without restraint. Likewise, restraints that were practised in wars within Europe in the nineteenth century did not apply in colonial interventions, which were never described as wars, rather as rebellions, insurrections, and so forth. There were attempts by Francis Lieber, who drew up the code of behaviour to be observed by both sides in the 
American Civil War, to define 'guerrilla parties' (Hartigan, I983). And the notion of 'armed conflict', involving volunteer corps or paramilitary groups, has been incorporated into international law. Nevertheless, the legal status of such groups is unclear within the framework of the laws of war. Since 200I, George Bush has used this kind of reasoning to justify the incarceration of what he calls 'illegal combatants' in Guantanamo Bay.

Nor did jus in bello apply in holy wars. In these wars the righteousness of the cause was supposed to justify the lack of restraint, as is the case today for the 'warriors' of jihad, and similar arguments have been applied to ideological wars. Moreover, the customary rules of war, developed in the Middle Ages, were designed to be applied 'between peoples sharing the same cultural background and worshipping the same Gods' (Bugnion, 2002). Thus they were respected, to a greater or lesser degree, in wars within Europe, among warring parties who shared an allegiance to the Christian church, but not beyond. When the crusaders captured Jerusalem, they had 65,000 'infidels' put to death.

In most contemporary wars the various warring parties have a nebulous status. They often do not fit the criteria, drawn up by Lieber and others (Hartigan, I983), for being treated as a proto-state, a sort of legitimate authority in waiting. Nor should they. To treat rebels or terrorists like Al Qaeda or the Hutu paramilitaries in Rwanda as potential authorities or as legitimate enemies would raise their status and confer on them an undesirable degree of legitimacy. On the other hand, to act without restraint and to ignore the framework of international law, as the Russians do in Chechnya or as President Bush does in relation to the Guantanamo detainees, can only exacerbate tension and undermine the legitimacy of actual authorities. 'Who will believe your cause when your behaviours are so unjust?' wrote the French Calvinists in relation to the wars of religion (quoted in Turner Johnson, I 98 I: 234).

This is why the language of law enforcement may be more appropriate than the language of Just War. Humanitarian intervention usually refers to intervention in a foreign country to protect civilians. Often humanitarian intervention is seen as war because it is the state that is responsible for violations of human rights, and because the intervention is done by states. But in situations where violations of human rights are inflicted by both state and non-state actors, both domestic and foreign, the term 'war' may not apply and it may be 
preferable to treat the situation as akin to domestic disorder. Rather than treating this kind of intervention as war or allowing the rules to be lost in the murky environment of peasant rebellions or colonial insurrections, it would be better to extend domestic rules and apply a minimum human rights framework. As Walzer (2000: 106) puts it, 'humanitarian intervention comes closer than any other kind of intervention to what we commonly regard, in domestic society, as law enforcement and police work'. The task in all these cases is the protection of civilians and the arrest of criminals rather than the defeat of enemy states.

If humanitarian intervention is viewed as the primary just cause and if humanitarian catastrophes are no longer only inflicted by states, then this has profound implications for the ways in which such interventions are conducted. The difficulties of applying the principles of jus in bello arise from this blurring of the difference between internal and external or friend and enemy, and between state and non-state, combatant and non-combatant. The central assumption underlying the rules of jus in bello is the immunity of non-combatants or combatants who are wounded or taken prisoner (what Michael Walzer calls the 'naked soldier'). They should be spared, where possible, the effects of war. They should be hors de combat. Nowadays, it is often argued that the notion of non-combatant immunity reflects an assumption about the equality of human beings and a notion of respect for enemy populations that earlier only applied within Europe (Erskine, I999).

However, the very concept of war implies a friend-enemy distinction in which enemy lives are less valuable than the lives of our own side. This contradiction between the friend-enemy distinction and respect for non-combatant immunity is expressed in different concepts variously known as 'proportionality', 'double effect' and 'collateral damage'. The idea behind these concepts is that killing or harming enemy civilians can be justifiable a) if it is a side effect of an attack on a military target, which is necessary in order to the win the war, b) if it is unintentional, and c) if the harm done is proportional to the harm that might be done if victory was not achieved. Of course, the concepts of 'necessity' and 'proportionality' are notoriously hard to define and allow for considerable leeway. In this context, James Turner Johnson (I98I) distinguishes between ad bellum proportionality and in bello proportionality. The former refers to the criteria for war itself, that it should do less harm than good; the latter 
refers to the application of minimal force, no more than is necessary to achieve a particular goal. If, as the Americans claim, recent wars in Afghanistan or Iraq are designed to prevent a terrorist from releasing a hideous weapon of mass destruction in a Western city, for instance, surely no amount of destruction would be permissible? But leaving aside, for the moment, the problem of definition, what these concepts effectively do is to create a hierarchy of lives.

Supposing we assume a war between Country $\mathrm{X}$ and Country $\mathrm{Y}$, then if you are on X's side, lives are valued in the following order. First come X's civilians, then come X's soldiers, then come Y's civilians, and finally Y's soldiers. Double effect implies that you should minimise all killing but deliberate killing of $Y$ 's soldiers is permissible if necessary to achieve victory or to save the lives of X's soldiers and civilians. Unintentional killing, of $Y$ 's civilians is permissible if necessary to achieve victory or to save the lives of $x$ 's soldiers and civilians. Actually, not everyone agrees about whether it is permissible to risk the lives of Y's civilians to save the lives of X's soldiers: During the Second World War, Pierre Mendes France, who flew on allied bombing missions, deliberately took the risk of flying low so as to be more accurate and save civilian lives. But this view does not seem to be accepted within the American military - hence the high flights over Yugoslavia in 1999. As one Us soldier put it in Kerbala: 'I think they thought we wouldn't shoot kids. But we showed them that we don't care. We are going to do what we can to stay alive and keep ourselves safe' (quoted in Burke, 2004).

Most of us do have an implicit hierarchy of lives, although this hierarchy is not necessarily defined in territorial terms. The communities to whom we feel loyal may cross borders and be defined in terms of family, ethnicity, religion, class or politics. The British suicide bomber in his suicide video talked about his community as the Muslim Umma rather than his local community in Leeds or the community of British citizens. But this kind of hierarchy, whether national or religious, is increasingly unacceptable as an international principle in the context of growing human rights norms.

There is no question that contemporary armies, American, British or Israeli, try to minimise civilian casualties and indeed claim that, thanks to new technologies, attacks from the air or from the ground are much more accurate and discriminate than ever before. According to former us Secretary of Defence Rumsfeld during the Iraq war: 'We are doing everything humanly possible to avoid collateral dam- 
age' (quoted in Crawford, 2003). By historical standards, 'collateral damage' in Kosovo, Afghanistan or Iraq has been relatively low. But what is low by the standards of war is high by the standards of human rights.

Thus in the Kosovo war of I999, some I, 200-2,500 people are estimated to have been killed as a consequence of allied bombing. ${ }^{5}$ This compares with some ı०,००० Albanians killed by Yugoslav forces on the ground. In Afghanistan and Iraq, the numbers of civilians killed was much higher than the number killed in the September I I attacks (which was around 2,800 people). In Afghanistan, some I, ০০oI, 800 people were killed directly as a result of American air attacks, according to media reports; estimates of Taliban and Al Qaeda troops killed vary from 4,000-10,000; many more were killed as a result of the humanitarian crisis caused by the war and some 560,000 people fled their homes (Connetta, 2002). In Iraq, the best estimate of civilian casualties both during and after the invasion up to November 2004 is probably at least 24,000 , of which the majority was the consequence of American attacks.

This estimate is based on the figures provided in the careful study reported in the British medical journal The Lancet. The study was based on sampling of clusters of households in all the governorates of Iraq. Excluding the Fallujah cluster, which had much higher casualties than elsewhere (accounting for two-thirds of violent deaths), the study found the rate of casualties to be much higher than actually reported to the press. The study estimated an additional 98,000 deaths excluding Fallujah, throughout Iraq. The biggest cause of death was violent incidents accounting for some 24 per cent of the total, of these the majority were caused by American air strikes (Roberts et al., 2004). Figures provided by the N GO Coordinating Centre for Iraq for the period September 2003 to November 2004 show, moreover, that because Americans are so much better protected than Iraqi civilians, the ratio of people killed in attacks on 'criminals and insurgents' is far higher than in insurgent attacks on American convoys. Some 26 people are killed on average in every attack on 'criminals and insurgents' while only one American is killed in every seven attacks on Coalition forces.

The problem is the changing perception of war. What appears to Americans as relatively low collateral damage in a Just War can equally be presented as large-scale human rights violations. From the point of view of the victims, does it make any difference whether they 
were killed in a war or as a result of repression, or whether the killing was intentional or unintentional?

A similar problem arises in the Israeli-Palestinian conflict. The world is, rightly, horrified by Palestinian suicide bombers' attacks where Israeli civilians are deliberately targeted. The Palestinian groups - Hamas, Islamic Jihad, or the Al Aqsa Brigades - are all included in the us State Department's list of international terrorist groups. Since the beginning of the second Intifada in 2000, they have killed $78 \mathrm{I}$ Israelis according to Ze'er Schiff $(2003)$ in the Israeli newspaper Ha'aretz. On the other hand, the Israeli security forces, who are state actors and therefore considered legitimate, and who are tasked with minimising civilian casualties, have killed 3,040 Palestinians, mostly civilians, including 606 children. According to the investigations of an Israeli human rights organisation, B'Tselem, at least I,66I of those killed (including $53 \mathrm{I}$ children under the age of I 8) were not involved in hostilities when they were killed (Human Rights Watch, 2005). ${ }^{6}$ Those Palestinians involved in the second Intifada claim that suicide bombing is necessary, and the only means available to them, in order to establish a balance of terror.

The high civilian casualty figures in Iraq and Palestine underscore another problem, namely the difficulty of distinguishing combatants and non-combatants. When insurgents hide in cities, how is it possible to attack them without killing civilians? This is the classic problem of counter-insurgency. Milošević claimed that attacks by Serbian forces in Kosovo were counter-insurgency not ethnic cleansing (Independent International Commission on Kosovo, 2000); Serb forces were merely trying to root out members of the Kosovo Liberation Army (KLA). In Chechnya, massive population displacement and killing has taken place that dwarfs anything experienced in Kosovo, as a result of Russian attempts to defeat the insurgency. The American attacks on Fallujah resulted in I 50,000 displaced persons as well as large numbers (unknown) of civilian casualties (Kaldor and Said, 2003).

The difficulty of distinguishing combatants from non-combatants was the central problem the us faced in Vietnam. Indeed, Walzer makes the case that where it is not possible to distinguish civilians from combatants, jus in bello and jus ad bellum come together and the war should not even be fought. 'The war cannot be won and it should not be won. It cannot be won because the only available strategy involves a war against civilians, because the degree of civilian 
support that rules out alternative strategies also makes the guerrillas the legitimate rulers of the country. The struggle against them is an unjust struggle as well as one that can only be carried on unjustly. Fought by foreigners, it is a war of aggression; if by a local regime alone, it is an act of tyranny' (Walzer, 2000: 196). But the difficulty of distinguishing combatants and non-combatants is characteristic of most wars and calls into question whether we can continue to talk about Just War.

\section{Just Peace}

The blurring of the distinction between external and internal, state and non-state, combatant and non-combatant implies the blurring of the distinction between war and peace. 'New wars' do not have decisive beginnings or endings. Nor are they clearly delineated in geographical space; they spread through refugees and displaced persons, organised crime, diaspora groups and so on. The growing body of human rights law cannot be suspended in wartime in the way that domestic laws, which apply to individual rights, have often been disregarded in the name of national security. That is why it is important to develop the concept of Just Peace and its concomitant, the Laws of Peace, which apply at an international level (Chinkin, 2006). Anthony Burke (2004) proposes a system of ethical peace that declares the 'illegality of avoidable harm'.

There is a role in such a framework for the use of military force. But the principles of legitimacy derive from individual rights rather than the rights of states. This is why the term 'human security' should be used. The term was first coined in the 1994 Human Development Report published by the United Nations Development Programme (UNPD) and has since been elaborated in the Commission on Human Security chaired by Sadiko Ogata and Amartya Sen (Ogata, Sen et al., 2003). The concept has been promoted by the Canadian government, which has established a network of governments that favour the concept. Human security combines human rights and human development, both freedom from fear and freedom from want. In much of the literature on human security, the emphasis is placed on 'freedom from want' but in what follows, I emphasise 'freedom from fear' and the role that military forces might play in human security operations. 
In a system of Just Peace, military forces are, of course, under the control of competent authorities, at present states. States remain the only authorities capable of upholding the legitimate use of force, but their use of force is much more circumscribed by international rules and norms than was the case in the past. In other words, the distinctions between inside/outside and between legitimate and illegitimate uses of force do remain although their meaning has changed (this is why I use the term 'blur' rather than 'supersede' or 'disappear'). Military forces are forces designed for use in external operations but not for war against other states, rather as a contribution to global security and to implementing a global social contract, which enshrines human rights. The legitimate use of military force by states would need to be approved by the UN or to conform to a clear set of criteria that are agreed upon internationally.

A set of criteria has been defined by the United Nations High Level Panel on Threats, Challenges and Change under the rubric of Responsibility to Protect (UN Report, 2004). Those proposed by the Canadian International Commission on Intervention and Sovereignty (Evans, Sahnoun et al., 200I) are drawn from Just War approaches and cover the criteria for right authority, including the importance of multilateral authorisation, and the right to intervene in cases of large-scale loss of life and/or large scale 'ethnic cleansing'. However, they would need to be supplemented by more elaborated criteria for the ways in which force should be applied, which distinguishes the methods to be adopted for the protection of individuals from warfighting methods.

If such criteria were to be adopted, then this would actually cover the case of external aggression. Instead of making human rights fit the framework of Just War, which it does rather uneasily, and which then allows loopholes for 'double effect' and 'collateral damage', aggression can be fitted into the Responsibility to Protect since aggression is not just against a state but against the individual citizens that compose the state. In other words, states can use military forces under the auspices of the UN, within a multilateral framework and according to agreed-upon criteria. They are to be used for the protection of civilians in conjunction with international police forces and civilian experts. In the future, human security forces may combine military, police and civil elements and operate rather differently from traditional armies (Barcelona Report, 2003).

Using military forces in a human security role is thus quite differ- 
ent from either classic war-fighting or from peacekeeping. Both types of operation are defined in terms of a war between collective enemies. The job of peacekeepers is to separate warring parties, monitor cease-fires or collect weapons. In the past, peace-keepers have often been unable to prevent violations of human rights. The job of warfighting is about defeating enemies, and even though counter-insurgency operations sometimes adopted a 'hearts and minds' approach, the task of protecting civilians was secondary to the task of defeating the enemy. The big gap in all recent operations has been public security. Thus the NATO operation in Kosovo failed to prevent ethnic cleansing first of Albanians and then of Serbs, even though it did succeed in liberating Kosovo and enabling the Albanians to return to their homes. The Iraq war failed to prevent looting as well as widespread human rights violations in the immediate aftermath of the war. Crime and human rights violations were widespread in Bosnia Herzegovina as well, even after the Dayton Agreement.

Yet how public or human security is to be achieved has received much less attention than the circumstances in which military means might be used. The methods of civilian protection (the 'how' rather than the 'why' of civilian protection) have been debated much less. It is as though the use of military force were a black box to be applied as a neutral instrument. In what follows, I set out three principles, which demonstrate the difference between a human security and a jus in bello approach.

\section{Protection}

First of all, the primary task of human security operations is the protection of civilians. Killing is never permissible except in self-defence or to save a third party. Thus the killing of an attacker is only permissible if it is necessary to save civilian lives. Of course, it could be argued that this also allows for war-fighting actions that may risk civilian lives. The British forces defending the un safe haven of Goradze in the last stages of the war in Bosnia Herzegovina did shell Serb forces for several hours in order to prevent the Serbs from overrunning the town and in order to negotiate the safe passage of civilians. This was in contrast to Srebrenica, where Dutch forces failed to prevent the massacre of 8,000 men and boys. One of the reasons why mandates were so restricted in Bosnia Herzegovina was because of fears that active defence of safe havens could slide into war; the term 'crossing the Mogadishu line' was coined by General Rose in refer- 
ence to the disastrous consequences of a shifting to a war-fighting strategy in Somalia (The Economist, January I996). However, there is a difference between active protection and war-fighting. In 'new wars', the warring parties do try to avoid battle because the growing symmetry of military technology makes the outcome dangerous and uncertain. One should not, of course, dismiss the risk of escalation or of an unconstrained extension of violence; in the confusion and emotion surrounding all wars, warring parties do not behave as expected and an extremist logic often takes over. But the starting point, in ethical and operational terms, is protection rather than defeat of an enemy, as opposed to the other way round, which is the characteristic of war.

\section{Stabilisation}

The second principle, linked to the first, is that protection can be achieved through stabilisation rather than victory. The aim is public security and this can only be done through the establishment of legitimate political authority. The rule of law and a well-functioning system of justice are essential to guarantee the safety of individuals and communities. Legitimate political authority does not necessarily need to mean a state, it could consist of local government or regional or international political arrangements like trusteeships, protectorates or transitional administrations. Since state failure is often the primary cause of conflict, the reasons for state failure have to be taken into account in reconstructing legitimate political authority (Wulf, 2006).

A legitimate political authority can only be established on the basis of a political process recognised as legitimate by the local population. This means that the local support and consent for human security missions are critical to their success. It also means that the role of the military in a human security operation is, therefore, to stabilise the situation so that space can be created for a political process. This is much more important than winning through military means. Of course, it can be argued that military victory is an effective method of stabilisation. This is what the Americans claimed in Iraq and it is a view that runs deep in military establishments. But in some cases, military victory may simply be beyond reach - every excessive use of force further inflames the situation. In other cases, short-term military victory can be achieved, but the cost in terms of both casualties and political legitimacy is high. Israeli forces, for instance, have suc- 
ceeded in slowing down the rate of suicide bombing, but this has not led to any resolution of the conflict; indeed, it has only inflamed more passion on the Palestinian side. Military victory may mean that stability can only be sustained through massive repression and coercion. In Algeria, the French won militarily but lost politically and the trauma of that war has left a lasting legacy.

\section{Criminal Law}

A third principle is that those who violate human rights are individual criminals rather than collective enemies. This means that human security forces have the job of arresting criminals and bringing them to justice. It also delegitimises the enemy, who are no longer political foes but lawbreakers (Kaldor and Salmon, 2006). Thus, British forces operating in Sierra Leone chose to arrest members of the 'West Side Boys' engaged in looting and pillaging a village rather than engaging them in a firefight. This greatly diminished their stature and correspondingly raised the credibility of the British forces. This approach is not easy. There is often a tension between what counts as political and what counts as criminal. In some cases, it is important to outlaw those who have committed terrible crimes in order to establish a legitimate political process. This is the case in the former Yugoslavia, where, in principle, excluding indicted criminals creates space for more moderate politics. Likewise, the political situation in Iraq would be greatly facilitated by a legal process that speeds up the indictment of those members of the Ba'ath Party who committed unspeakable crimes. On the other hand, it may also be important to include groups like the Irish Republican Army (IRA) or Hamas, which are viewed as legitimate by some parts of the population, in the political process.

\section{Borneo and Belfast}

The experience of the British army in Northern Ireland could be considered a good model for human security operations and also illustrates some of the difficulties. The example is instructive because it is probably closest to the kind of operations I am proposing. Northern Ireland was a learning process for the British government because it was effectively a 'new war' on British territory. When British troops were first deployed in Northern Ireland in 1969, the most recent 
experience of most soldiers was counter-insurgency against anticolonial insurgents in Aden. As one soldier put it:

'We weren't governed by the same rules that we were in Ireland. The lads over there (Aden) could be a lot rougher, a lot harder because we never had the newspapers there and we never had the Press there or anyone else who could see what we were doing. It made a lot of difference because you were given a freer hand right across the board' (quoted in Taylor, 200I: 32)

When the army was first deployed in Northern Ireland, the difference between Aden and Northern Ireland or between 'Borneo and Belfast' as another soldier put it, was not sufficiently appreciated. The army relied heavily on the existing civil authority, which was itself a party to the conflict. It failed to protect the nationalist community from house burnings and expulsions, which stimulated the militarisation of the IRA. It used interrogation and intelligence techniques developed in colonial wars, later ruled illegitimate by the European Court of Human Rights. It used excessive force, most notoriously in breaking up IRA-established 'no-go' areas, and on 'Bloody Sunday', 30 January 1972, when the Parachute Regiment fired on a crowd and killed I 3 people (Pringle and Jacobson, 2000). Between I969 and I974, some I 88 people were killed by security forces and 65 per cent of the deaths were unarmed civilians (Ni Aoláin, 2000). This period was the bloodiest period of the whole Northern Ireland conflict (I969-I997), accounting for 90 per cent of all deaths - many more people were killed by Loyalist (Protestant) and Republican (Catholic) paramilitaries.

As a consequence of the failure of the armed forces to maintain peace and security, a new policy was adopted, known variously as 'normalisation', 'criminalisation' or 'Ulsterisation'. The emphasis was placed on police primacy in dealing with insurgents, and captured terrorists were to be treated as criminals rather than enemies. They were to be tried and given the same status in prison as ordinary criminals. The job of the armed forces was to support the police. Army bases were often co-located with police stations, which allowed proper sharing of information and joint tactical planning (Kaldor and Salmon, 2006). This approach lasted until the Good Friday Agreement in April I997, which largely ended the violence. 
It was an approach that did succeed in containing violence - over the period as a whole, I969-I997, some 4,000 people were killed, 350 by security forces. But it had its weaknesses. There was never a clear legal framework, and the procedures used to deal with captured insurgents represented considerable modification of normal law - the notorious 'Diplock' courts did away with juries and allowed confessional-based evidence, which accounted for the majority of convictions. The IRA always insisted that they were political and not criminal, and the hunger strikes in I98I to achieve political status in prison mobilised considerable political support for the IRA. The authorities themselves were often ambiguous, using 'war' arguments when needed to justify certain actions. Moreover, in the I980s, undercover operations by the SAS and other special forces lead to the killing (as opposed to arrest) of many IRA activists often in planned ambushes. It is sometimes argued that this strategy of attrition did lead to a situation where neither side could win and a political agreement was the only way out. But it is also the case that this behaviour contributed to the polarisation of Northern Irish society so that the extremist groups on both sides became the dominant political forces.

What made Northern Ireland different was the fact that the conflict took place on British territory. Bombing Belfast was not an option. It could also be argued that the different response of American authorities to the Oklahoma bombing (I995) as opposed to September I I can be explained partly by the fact that this was a domestic rather than an international incident. The assumption that underlies a Just Peace is that it is no longer possible, or relevant from the point of view of the victims, to distinguish between foreigners and citizens or between the domestic and the international. Although the state has primary responsibility for dealing with domestic violence, there are external situations where the local state itself is the cause of violence or where it is incapable of dealing with violence, where international forces intervene but through methods that are not so very different from the methods that might be used in a domestic setting. This reflects both the changed sensibilities of society where concerns about people far away have become more urgent as a result of global communications and transnational communities, and an emerging global social contract whereby the international community adopts the Responsibility to Protect and recognises individual rights and not just state rights.

Of course, elements of these principles can also be found in Just War theorising, particularly in the pre-Westphalian era. Thus, the 
emphasis on the protection of citizens is very much in keeping with notions of charity, humanitarianism and civilisation that have run through the Just War literature. The need for legitimate political authority and the priority of stabilisation or peace rather than victory could be considered an Augustinian principle. The notion that the enemy is an individual was central to the thinking of Vitoria. Moreover, any attempt to codify the Laws of Peace would need to incorporate humanitarian law but alongside human rights law. It is human rights and the notion of global public authority that marks this approach off from traditional Just War approaches.

\section{Conclusion}

George Weigel, a senior fellow at the Ethics and Public Policy Center in Washington, D.C., has suggested on several occasions that the 'new things' in the world today, particularly failing states and rogue states, explain the need for a new kind of Just War, in which individual states take responsibility for 'regime change' using new precise and discriminate technology (including, among others, Weigel I994). His argument is reflected in the national security strategy announced by George Bush in 2002. I agree with Weigel that in our interconnected world, rogue states and failing states are unacceptable. But I am very sceptical about the use of war-fighting as a way of bringing about 'regime change'. The wars in Iraq and Afghanistan have not created legitimate political authorities - they have speeded up the process of state failure, contributing to an environment in which various armed groups can operate, and have accentuated a friend-enemy distinction that attracts young disaffected people to extremist causes. However discriminate and proportionate these wars appear from a Western perspective, the civilian victims, even if not numerous by the traditions of twentieth-century wars, perceive these actions very differently, as do members of linked transnational communities across the world, especially Muslims.

Yet the 'soft power' approach of the European Union is not able to deal with the needs of millions of people in the world who live in conditions of intolerable insecurity. In the new war zones, whose borders are permeable and undefined, in places like the Middle East, the Balkans, West and Central Africa, Central Asia, or the Caucasus, individuals and communities live in daily fear of being killed, robbed or 
kidnapped, losing their homes, or being tortured or raped. Neither current security arrangements, based on traditional state-based assumptions about the nature of war and the role of military forces, nor the 'soft' approaches of international and regional organisations are able to address these everyday risks.

I have proposed that those who are wrestling with the problem of what constitutes the legitimate use of military force should adopt a human security approach rather than try to adapt more traditional Just War thinking, even though some of the insights drawn from the notion of Just War may be relevant. A human security approach is more straightforwardly applicable to the security problems we face today. Human security is sometimes considered a 'soft' security approach, relegated to the aftermath of conflicts when police and development experts are supposed to 'mop up'. What I have argued is that human security should be regarded as a hard security policy aimed at protecting individuals rather than states.

As such, a human security operation is actually more risky than current war-fighting operations. The human security officer risks his or her life to save others, rather as police and firefighters are expected to do in domestic situations. But in 'new wars', the risks are likely to be greater. It is often argued that politicians would be unwilling to take such risks and this is why, in many international missions, force protection receives higher priority than the protection of civilians. Western publics may be more willing to take such risks than politicians assume. After all, human rights activists, who volunteer, routinely take such risks.

\section{Notes}

I Most sources mention 55-57 million deaths for WW II (about I9 million military and 36-38 million civilian deaths); estimates for WWI show more variation, especially in calculating the civilian death toll: 8.5-9.4 million military casualties and 5-I 3 million civilian deaths. Here we follow Matthew White's figures of $\mathrm{I} 5$ million overall for WWI and, 55 million overall for WWII: http://users.erols.com/mwhite28/2ocentry.htm.

2 For a discussion of the debates around humanitarian intervention, see Wheeler 2000.

3 transatlanticassembly.blogspot.com/2005/03/24th-march-1999-bombing-ofserbia.html. 
4 According to the Palestinian Red Crescent Society, which does not distinguish between combatants and civilians, between 29 September 2000 and I 3 May 2005, 3,607 Palestinians had died and 28,695 were injured (http://www.palestinercs.org/the_fourth_year_intifada_statistics.htm). Wikipedia mentioned in September 2007 a death toll between 2000-2007 of over 4,200 Palestinians and over I, o०o Israelis (en.wikipedia.org/wiki/AlAqsa_Intifada).

\section{References}

(Barcelona Report) Study Group on Europe's Security Capabilities (2003), A Human Security Doctrine for Europe: Report of the Barcelona Study Group on Europe's Security Capabilities, Barcelona, I 5 September 2003, available online: http://www.lse.ac.uk/Depts/global/Publications/HumanSecurityDoctrine.pdf; also published in: Glasius and Kaldor (2006), pp. 327-356.

Bugnion, François (2002), “Just Wars, Wars of Aggression and International Humanitarian Law”, International Review of the Red Cross, Vol. 847, No. 84, pp. 523-546.

Burke, Anthony (2004), "Just War or Ethical Peace? Moral Discourses of Strategic Violence After 9/I I”, International Affairs, Vol. 80, No. 2, pp. 329-353. Chinkin, Christine (2006), "An International Law Framework for a European Security Strategy”, in: Glasius and Kaldor (2006), pp. I73-I99.

Clark, Ian (I999), Globalization and International Relations Theory. Oxford: Oxford University Press.

Connetta, Carl (2002), "Strange Victory: A Critical Appraisal of Operation and Enduring Freedom and the Afghanistan War", Project on Defense Alternatives, Research Monograph No. 6, 30 January 2002.

Crawford, Neta C. (2003), "Just War Theory and the U.S. Counter terror War" Perspectives on Politics, No. I, pp. 5-25.

Der Derian, James (200I), Virtuous War: Mapping the Military-Industrial-Media-Entertainment Network, Boulder, CO: Westview Press.

Erskine, Toni ( I 999), "Embedded Cosmopolitanism and the Case of War: Restraint, Discrimination, and Overlapping Communities", Paper presented at the B IS A Special Workshop on Cosmopolitanism, Distributive Justice and Violence, I-3 May, I999.

Evans, Gareth, Mohamed Sahnoun, et al. (200I), The Responsibility to Protect: Final Report of the International Commission on Intervention and State Sovereignty, Ottawa: International Development Research Centre.

Glasius, Marlies and Mary Kaldor, Eds. (2006), A Human Security Doctrine for Europe: Project, Principles, Practicalities, London: Routledge. 
Hartigan, Richard Shelly (1983), Lieber's Code and the Law of War, New York: Transaction Publishers.

Held, David (2004), The Global Covenant: The Social Democratic Alternative to the Washington Consensus, Cambridge: Polity Press.

Human Rights Watch (2005), Promoting Impunity: The Israeli Military's Failure to Investigate Wrongdoing, New York, http://hrw.org/reports/2005/iopto605.

Independent International Commission on Kosovo (2000), The Kosovo Report: Conflict, International Response, Lessons Learned, Oxford: Oxford University Press.

Kaldor, Mary (1999), New and Old Wars: Organized Violence in a Global Era, Cambridge, Polity Press.

Kaldor, Mary (2003), Global Civil Society: An Answer to War, Cambridge: Polity Press.

Kaldor, Mary and Yahia Said (2003), "Regime Change in Iraq”, Centre for the Study of Global Governance, Discussion Paper, 26.

Kaldor, Mary and Andrew Salmon (2006), "Military Force and European Strategy”, Survival, Vol. 48, No. I, pp. 19-34.

Langan, John (1984), “The Elements of St Augustine's Just War Theory”, The Journal of Religious Ethics, Vol. I2, No. I, pp. 28-37.

Ni Aolain, Fionnuala (2000), The Politics of Force: Conflict Management ad State Violence in Northern Ireland, Belfast: Blackstaff Press.

Ogata, Sadako, Amartya Sen, et al. (2003), Human Security Now: Final Report of the Commission on Human Security, New York; http://www.humansecurity-chs.org/finalreport.

Pringle, Peter and Philip Jacobson (2000), Those are Real Bullets, Aren't They?, London: Fourth Estate.

Roberts, Les, Lafta Riyadh, Richard Garfield, Jamal Khudhairi and Gilbert Burnham (2004), "Mortality Before and After the 2003 Invasion of Iraq: Cluster Sample Survey”, The Lancet, 29 October 2004, No. 355 , pp. I 85 II 857 .

Schiff, Ze'er (2003), “Summit Analysis” Ha'aretz, 5 June 2003.

Taylor, Peter (200I), The Brits: The War against the IRA, London: Bloomsbury. Turner Johnson, James (I98I), Just War Tradition and the Restraint of War: A Moral and Historical Enquiry, Princeton: Princeton University Press.

United Nations (2004), A More Secure World: Our Shared Responsibility, New York: United Nations, December 2004, A/59/56.

Walzer, Michael (1992), Just and Unjust Wars: A Moral Argument with Historical Illustrations, $2^{\text {nd }}$ edition, New York: Basic Books.

Walzer, Michael (2000), Just and Unjust Wars: A Moral Argument with Historical Illustrations, New York: Basic Books, $3^{\text {rd }}$ edition. 
Walzer, Michael (200I), "First, Define the Battlefield”, New York Times, 2 I September 200I.

Walzer, Michael (2004), Arguing About War, New Haven: Yale University Press.

Weigel, George (I984), Idealism Without Illusions: U.S. Foreign Policy in the I990s, New York: Eerdmans.

Wheeler, Nicholas (2000), Saving Strangers, Oxford: Oxford University Press. Wulf, Herbert (2006), "The Challenges of Re-Establishing a Public Monopoly of Violence”, in: Glasius and Kaldor, Eds. (2006), pp. 20-39. 


\title{
$3 \quad$ Failing Global Justice and Human Security
}

\author{
Willy Bruggeman
}

People's security around the world is interlinked, as is highlighted by today's global flows of goods, services, finances, people and images. Political liberalisation and democratisation open new opportunities but also new fault-lines, such as political and economic instabilities and conflicts within and between states. More than 80,000 people a year die as a consequence of violence, according to the Commission on Human Security (Ogata, Sen et al., 2003). Human security means protecting vital freedoms. It implies the protection of people from critical and pervasive threats and situations. Therefore, global justice is essential. During the Cold War, security was essentially defined in military terms, primarily as the avoidance of a direct military danger. When the Cold War ended, it was generally thought that a new international era was about to begin. Liberated from the overarching emphasis on military security, international diplomacy turned its efforts and attention to those challenges that were of importance to everybody's daily life.

The post-Cold War environment is one of increasingly open borders. Flows of trade and investment, the development of technology and the spread of democracy have brought growing freedom and prosperity to many people. In spite of these encouraging trends, many problems remain unsolved and some are even exacerbated. Specific political-military challenges stand out: regions of chronic tension and long-standing disputes and conflicts, failed states and civil wars, excessive militarisation, terrorism and organised crime. Regional conflicts continue to foster instability, disrupt economic activity and reduce opportunities for the people concerned. In many parts of the world, bad governance, civil conflict and the easy avail- 
ability of small arms have led to a weakening of state and social structures. Corruption, abuse of power, weak institutions and lack of accountability corrode states from within and contribute to regional insecurity. Conflict not only destroys infrastructure, including social infrastructure, it also encourages criminality, deters investment and makes normal economic activity impossible. A number of countries and regions risk becoming caught in a downward spiral of conflict, insecurity and poverty. A renewal of ethnic conflicts could plunge many countries and regions into a state of anarchy. In addition, international terrorism and the proliferation of weapons of mass destruction remain nowadays the single most important threat to peace and security among nations and worldwide.

In a world of global threats, global markets and global media, our security and prosperity depend on an effective multilateral system. Justice mechanisms should contribute to the development of a stronger international society, well-functioning international institutions and a rule-based international order on the condition that it is part of coherent and comprehensive approach. But in reality, military instruments, security policy, international cooperation, multilateral treaties, international and military tribunals, and NATO relations are issues that operate in isolation and have been separating the two sides of the Atlantic.

\section{The Prevention of and Fight against Global Problems}

The I990s witnessed the rise and fall of the sense of a shared global fate. Intractable problems, both economic and political, challenged the prospects of rapid successes in global governance. Member states failed to buttress the institutions intended to deal with global problems, with the competences and resources needed to attain the goals that they were expected to pursue. Therefore, after the atmosphere of euphoria and a strong belief in the feasibility of the polity, the postCold War ended in its mirror image. We are now living in times of global tensions and divisions, where consensus and cooperation are in jeopardy.

Bad governance is often at the heart of the problems. Illegal drugs and human trafficking, organised crime, war crimes, genocide, terrorism, ecological dislocation, infectious diseases and financial turmoil showed how borderless forces have exploded faster than our 
ability to cope with them. The international community failed to put an early end to human suffering in Somalia, Yugoslavia, Rwanda, Congo and Sudan. Parts of the world imploded, especially in Africa, while the international community stood by, powerless (Coolsaet, 2003). Then 'nine-eleven', Afghanistan and Iraq followed. These issues are like global warming: the consequences are diffuse and only perceptible over the long term. But at a certain point, the resulting strains will have become uncontrollable.

In today's world, a threat to one is a threat to all. Globalisation means that a major terrorist attack anywhere in the industrial world can have devastating consequences for the well-being of millions in the developing world. It is noteworthy and encouraging that in 2004 the un created the High Level Panel on Threats, Challenges and Change to generate new ideas about the kind of policies and institutions required for the UN to be effective in the twenty-first century (UN Report, 2004). Its report states that we live in a world of new and evolving threats, threats that could not have been anticipated when the UN was founded in 1945, threats such as nuclear terrorism and state collapse from the tangled web of poverty, disease and civil war. Different threats are becoming more and more prominent. The links between terrorism, organised crime and guerrilla activity have been examined, to conclude that there is a convergence between these phenomena in some cases (Lejeune, I998).

The erosion of state power against international threats such as terrorism and organised crime requires international cooperation. There are six clusters of threats with which the world must be concerned now and in the decades ahead (UN Report, 2004): war between states; violence within states, including civil wars, large-scale human rights abuses and genocide; poverty, infectious disease and environmental degradation; nuclear, biological, chemical and radiological weapons; terrorism; and transnational organised crime. Although these threats cannot be seen in isolation, a distinction can be made in the limited framework of this chapter.

\section{War, Genocide and Crimes against Humanity}

Many regions in the world are confronted with serious war situations, which are often the origin of violations of international law in connection with war, genocide and crimes against humanity. These 
conflicts are often of ethnic origin. Warlords are not only involved in massive killings, but also part of organised crime and terrorist networks. Only some of these crime situations are the subject of prosecutions, be it at the national or at international level. The Nuremberg Tribunals set the first principles to put individuals on trial for crimes committed in the name of the state. The Genocide Convention (I948) called for the establishment of a permanent international court, but efforts were blocked. In I989 Trinidad and Tobago reintroduced the idea of a permanent international criminal court to the un General Assembly.

Although there was no progress with regard to setting up a court, the body of international criminal law related to it grew. By the I 980 s, the UN had managed to agree on a definition of aggression (1974), adopted the Genocide Convention (1948), the Convention on Torture (1984), the Convention against Apartheid (I973), as well as the Geneva Conventions (1949) and their additional Protocols (1977) protecting the rights of combatants and civilians during armed conflicts. However, all of these conventions at best established a duty for states to nationally prosecute or extradite perpetrators.

In 1993 the Security Council established the International Criminal Tribunal for the former Yugoslavia (ICTY) and in I994 a corresponding tribunal for Rwanda (ICTR), often referred to as ad hoc tribunals. Since 1995, the ICTY and the ICTR have been investigating, prosecuting and bringing to justice some of these acts of ethnic cleansing and genocide. The Rome Statute establishing the International Criminal Court (ICC) of I 7 July I 998 affirms that the most serious crimes of concern to the international community as a whole, in particular genocide, crimes against humanity and war crimes, must not go unpunished and that their effective prosecution must be ensured by taking measures at the national level and by enhancing international cooperation. The Rome Statute recalls that it is the duty of every state to exercise its criminal jurisdiction over those responsible for such international crimes and emphasises that the ICC is to be complementary to national criminal jurisdictions. The successful outcome of the effective investigation and prosecution of such crimes requires close cooperation between authorities of those states that are parties to the Rome Statute and the international tribunals.

These ad hoc tribunals and the ICc, although empowered with jurisdiction for the prosecution of international crimes, significantly differ from the WWII tribunals. The ICC is a multilateral, treaty- 
based, permanent court with the status of an independent international organisation, separate and apart from the un. The Court will exercise its jurisdiction only when a state is unwilling or unable to proceed with a viable prosecution. The establishment of the ICC is a prominent example of a fairly recent legalisation process. Such attempts to alter the institutional and normative setting of law-making processes are often carried out by transnational alliances between middle powers and non-state actors which increasingly coordinate their strategies (Deitelhoff, 2004). Due to recent developments, a dilemma for the future is to determine when war becomes crime and vice versa (Dieben, 2005).

\section{Nationalism and Ethnic Conflict}

Nationalism can take different forms, from benign patriotism to malign chauvinism. Ethnic conflicts remain the main root cause of crime situations against humanity. To establish the extent to which regional nationalism carries a real danger of ethnic conflict, two factors have to be taken into consideration.

First, the nationalism of ethnic minority groups that have a majority in another country carries severer risks than the nationalism of groups which cannot count on the effective support of a nation represented by a state. Second, there is a significant difference between minorities dispersed over a large geographical area, in most cases mixed with other majority groups, and minorities in separable entities in the vicinity of the mother nation.

The most frequently mentioned source for instability is the reemergence of territorial claims. Much depends on whether they consider the use of force to attain their objectives or whether they rely exclusively on peaceful means. The three basic state or war-making instruments (monopolising violence or the means for that purpose, accumulating wealth, and offering protection) are also the distinctive features of an organised criminal organisation (Peleman, I998). Faced with recent civil wars such as those in Bosnia Herzegovina, Liberia or Rwanda, the traditional framework as used, for example, for analysing the Cold War has been reviewed. Instead, chaos theories have emerged, trying to explain the irrationality and brutality of these conflicts. The argument goes that long-suppressed tribal, ethnic or national rivalries have been relinquished after the Cold War. War 
is not simply a breakdown or a failure of a particular system, but also a way to create an alternative system of profit, power and protection (Keen, I998). This thesis may not exhaustively explain the different aspects of the conflict, but it can shed light on the behaviour of its decision-making entities, be they political leaders or non-state parties such as warlords, militia leaders, rebels and criminal gangs.

During the I 990 , the international community took unprecedented steps to limit the impunity all too often associated with mass slaughter, forced dislocation of ethnic groups, torture, and rape as weapons of war. Along with genocides and widespread crimes, the decade was marked by the creation of international criminal justice mechanisms and the application of universal jurisdiction to hold perpetrators of the most serious crimes to account. Soon after the Cold War - and with the stark failures of national court systems freshly in mind - the UN, a number of governments, and many NGOs worked to create international criminal courts.

Over the past decade, several European states also began to meet their obligations to prosecute those accused of atrocities found on their territory. Using domestic universal jurisdiction laws in domestic courts, Switzerland, Denmark, Belgium, Germany and other states have tried such individuals far away from the countries where the crimes were committed. These different developments taken together have formed the components of a new, fragile, yet unprecedented, system of international justice consisting of ad hoc tribunals, the permanent ICC and various other international mechanisms.

\section{Terrorism}

Religious zeal or political goals drive terrorists. Recent terrorist attacks illustrate the privatisation of violence and globalisation of insecurity more than ever before. International terrorism has become a strategic threat to all states, and to the world community. The new terrorist movements seem willing to use unlimited violence and cause massive casualties. The tragic events of September I I, 200 I, should not be considered as 'attacks' anymore, but as 'massacres', in lay parlance, and as a crime against humanity according to international law (Mendez, 2002). The horror of what happened that morning results from the occurrence of the large-scale and premeditated random killing of people over a short period of time, in a context that is 
revolting for its massiveness and the innocent people killed in it, whatever motives the killers may have been prompted by to commit the massacres.

Terrorist organisations typically maintained a presence worldwide in order to raise and transfer funds, to create false identities for operatives, to procure weaponry and material, to set up operational sanctuaries, and to support infiltration across the borders and overseas. The term 'terrorism' was never defined by law in any consensual manner until the European Union, in the Treaty of Amsterdam, offered a setting for international law enforcement cooperation aimed at terrorism, but this cannot be extrapolated to other regions of the world.

The first attempt to reach an international agreement on terrorism was made in 1937 within the League of Nations. However, its dissolution on the eve of the Second World War aborted this initiative. One of the measures considered by the League of Nations was the creation of an International Criminal Court (Alexander, Carlton and Wilkinson, I979: 232), responsible for trying international terrorists and sea pirates. The UN never achieved a comprehensive treaty on terrorism for several reasons: its membership includes nations that actively sponsor terrorists; the member states could not reach agreement on how to distinguish terrorism from liberation wars. Especially the African and Asian member states feared that such a treaty would endanger the right to self-determination of populations. They explicitly emphasised the legitimacy of violence in the struggle for national liberation and the use of tactics such as hostage taking. The third problem has been the inability of the UN to enforce a treaty, which makes drafting one a sometimes futile exercise.

The Council of Europe issued the 1977 Strasbourg Convention on the Suppression of Terrorism. More recently, the G-8, as a periodical conference of the heads of state and government of the eight most industrialised countries in the world, has become more intensively involved with anti-terrorism. The strength of their effort lies in the fact that they do not solely count on international treaties to resolve the problem, but pay attention to alternatives, such as specific security action programmes like the security standards set by the International Civil Aviation Organisation.

In December 200I, the European Union declared that the struggle against terrorism was to be defined as a joint action. Dozens of measures were taken to concretise this, ranging from a common arrest 
warrant valid throughout the $\mathrm{EU}$, through a joint definition of terrorist activities (comparable to that of the 1937 League of Nations Convention), to a routine exchange of information on terrorists through Europol (promoted during the interwar years period, but never put into actual practice). The unique cooperation of police forces and juridical services within the European Union is actually based on the nineteenth-century principle that terrorism is not a legitimate political activity but a criminal offence. The 2004 Madrid bombings further consolidated the intra-European cooperation, leading to an expansive programme of anti-terrorism measures in the EU Area of Freedom, Security and Justice, and to the creation of a Framework Decision in $\mathbf{2 0 0 4}$ on preventing and combating terrorism.

The us clearly expressed its wish to make the fight against terrorism the new priority, but the European discourse has not embraced the idea of a Global War on Terrorism. Behind these differences in opinion, there are divergent policies with regard to defence spending. Nine-eleven not only led the us to declare itself at war, it also culminated in a sizeable increase in us military spending and brought about the biggest governmental restructuring in fifty years by creating a new Department of Homeland Security. Planned increases of projection capability are only of minor benefit to civil defence and means are specifically earmarked to combat terrorism. Meanwhile, however, significant progress has been made in the fields of police, justice and finance.

Decisions taken both in the Us and the EU for protecting their societies from new attacks have been subject to serious debate on both sides of the Atlantic. One of the main elements in the democracy versus terrorism debate is military tribunals, such as those that have been put in place in the us. These appear reprehensible to Europeans for two reasons: they are a departure from the rules of democratic societies, and they prevent the cooperation that is essential for fighting terrorism. Exceptional jurisdictions are by definition a brake on international cooperation (as is well highlighted in Amnesty International's 2002 Yearbook). It is also significant that on I 6 February 2006 Un Secretary-General Kofi Annan said the United States should close the prison for terror suspects in Guantanamo Bay as soon as possible, backing a key conclusion of a UN-appointed independent panel. Additionally, the Un High Commissioner for Human Rights, Louise Arbour, stated on the occasion of Human Rights Day (7 December 2005) that the right to be free from torture and cruel, inhu- 
man or degrading treatment is not to be banned, not even when the threat of international terrorism calls for increased coordination by law enforcement authorities within and across national borders.

UNSC Resolution I373, adopted only two weeks after nine-eleven, was one of the most expansive resolutions in the history of the Security Council. It made it mandatory for all member states to do everything within their power to stop the support and financing of terrorist acts. The Security Council also created a special committee, the Counter-Terrorism Committee, to monitor the implementation of all agreements, in the meantime turned into national laws by most of the member states. Resolution I 566, adopted in October 2004, further enhanced the Security Council's role by reinforcing the international regime of sanctions against and the monitoring of a whole range of individuals, groups and entities associated with terrorist activities.

A few days after nine-eleven, for the first time in its history, the NATO alliance declared that they were prepared to put into effect the solidarity clause, as laid down in Article 5 of the Charter, thus automatically equating a terrorist attack with a military attack on all member states.

Especially violent radicalisation is nowadays the subject of several political initiatives at national, regional and international levels. ${ }^{\mathrm{I}}$ Burgess (2007), however, is of the opinion that some of these measures fail to isolate radicalisation as a key process in the recruitment to extreme behaviour or, as the case may be, terrorism.

\section{Non-Conventional Attacks}

Whereas it was a minor concern during the Cold War, the spread of nuclear, biological and chemical weapons, as well as the means of getting them to their targets, has now gradually become one of the main issues for security policies. For about a decade, fears of nuclear, biological, chemical and radiological (NBCR) terrorism have been in the minds of governments and experts, but have remained unknown to the wider public. This is one of the more alarming aspects of international terrorism. Since January I992, the spread of these weapons - which are described as weapons of mass destruction - to new states is officially held to be one of the main threats to international security. This threat environment is characterised by elusive, widely dispersed and loosely structured terrorist networks (e.g. Al Qaeda), ca- 
pable of deploying large numbers of trained, committed operatives almost anywhere in the world. Several reports proved that numerous members of Al Qaeda are excellent chemists, capable of developing deadly weapons out of easily available products (Delpech, 2002).

Thus far there has never been an attack involving a nuclear device, and terrorists seem to have a preference for chemical and biological weapons. Most experts agree that nuclear weapons are beyond international terror groups. Sensational news items about chemical, biological and bacteriological weapons have to be approached with some prudence, too. International terrorist groups have found it easier to blow up gas tanks or chemical storage facilities than to manufacture usable chemical weapons. However, the fact that the immediate danger should be put into perspective does not mean that there is not a genuine risk of radioactive, bacteriological or chemical material ever falling into the hands of terrorist organisations or of lone individuals, as was probably the case with the anthrax-filled envelopes that almost paralysed public life in the Unites States shortly after nine-eleven.

The International Atomic Energy Agency (IAEA) has confirmed more than a dozen cases of smuggled nuclear-weapons-usable materials, and hundreds of cases have been reported and investigated over the last decade (IAEA, 2005). The potential demand is strong and growing. Constrained supply and increasing demand cause prices to rise and create incentives for illegal activities.

The IAEA is concerned with helping the international efforts to fight terrorism and protecting the development of peaceful deployment of atomic energy throughout the world. The only way to counter this risk, according to the IAEA, is the strict 'cradle-to-grave control of these substances'. ${ }^{2}$ Only long-term international and multilateral cooperation can achieve this. This point was emphasised in June 2004 by IAEA director Mohamed ElBaradei when he warned the international community that it was a 'race against time it cannot afford'. Over 70 states have since arranged with the agency to exchange information regarding the industry. In addition, the IAEA has taken a number of other initiatives to prevent the proliferation of nuclear components.

The Organisations for the Prohibition of Chemical Weapons (OPCW) - an intergovernmental organisation with an independent legal body, based on the Chemical Weapons Convention (CWC) - is the most prominent international organisation active in investigating 
any known proliferation of chemical weapons (Coolsaet, 2005). The use of biological weapons is outlawed by an international convention that dates back to 1925 , and the production and storage of biological weapons are banned by the 1972 convention. It is hardly surprising that bio-terrorism, against which there is currently little protection, has caught the attention of governments. In 200I, the heads of state and governments of the $\mathrm{EU}$ decided to establish a programme to fight bio-terrorism, and at the Laeken European Council on I4-I 5 December $200 \mathrm{I}$, a decision was taken to create a European Civil Protection Agency.

\section{Organised Crime}

The spread of transnational organised crime increases the risk of all other threats. In general, the illegal trade in drugs, arms, intellectual property, people and money is booming. Drugs and arms often go together. According to the UN, only I 8 million (or about 3 per cent) of the 555 million small arms and light weapons in circulation today are used by governments, military or police forces (UN Programme of Action on Small Arms and Light Weapons, November 2004). Small arms helped fuel 46 of the 49 largest conflicts of the last decade, and in $200 \mathrm{I}$ were estimated to be responsible for a thousand deaths a day (Naim, 2003). The illegal markets for ammunition, smuggling money, gold coins, diamonds and other valuables form an ancient trade. Money launderers are still equipped to launder suitcases full of banknotes, but computers, the Internet, and complex financial schemes that combine legal and illegal practices and institutions are more common. Highly decentralised groups and individuals are bound by strong ties of loyalty and common purposes and organised around semi-autonomous clusters or 'nodes' capable of operating swiftly and flexibly, as is regularly stated in Europol's yearly reports on organised crime. The promise of enormous financial gain motivates those who fight governments in these wars. Like the Global War on Terrorism, the fight to control these illicit markets pits governments against agile, stateless and resourceful networks empowered by globalisation.

Never fettered by the sovereignty principle, the organised criminal networks are free of geographical constraints. Moreover, globalisation has not only expanded illegal markets and boosted the size and 
the resource of criminal networks, it has also imposed more burdens on governments. In many parts of the world, bad governance, civil conflict, and the easy availability of small arms have led to a weakening of state and social structures. Somalia, Liberia and Afghanistan are the best-known recent examples. The weakness of the state is often exploited (and sometimes caused) by criminal elements. Revenues from drugs have fuelled the weakening of state structures in several drug-producing countries; in Afghanistan, drug revenues have kept the Taliban and several private armies in power. When states fail, it becomes easy for organised crime to take over.

Prior to nine-eleven, the problems of organised crime and terrorism were often considered separate phenomena. Security studies, the military, and law enforcement increasingly view terrorism and transnational crime as strategic threats. These problems are no longer seen as distinct (Shelley, 2004), but as central threats to national and international security. According to Shelley, the following are illustrations of links between organised crime and terrorism:

- terrorists engage in organised crime activity to support themselves financially;

- organised crime groups and terrorists often operate in network structures and these structures sometimes intersect;

- terrorists can go undercover in criminal transnational organisations;

- both organised crime groups and terrorists operate in areas with little governmental control, weak enforcement of laws, open borders and conflict areas;

- both corrupt local officials to achieve their objectives;

- both often use similar means to communicate, exploiting modern technology;

- both launder money, often using the same methods and often the same operators to move their funds.

The increasing share of the world economy attributable to illicit activity provides the financial resources for transnational crime groups to operate and hire expertise. The sources of the illicit capital are illegal commodities such as drugs, smuggling and trafficking of human beings, small arms and valuable natural resources (such as timber), and piracy, some of it linked to the maritime transport of high technology. Counterfeiting of goods, currencies, CDs and other electron- 
ic equipment forms a major financial support for organised crime. The resources of the terrorists or the profits of transnational crime groups are combined with legitimate funds, making it hard to detect where the illicit funding ends and the legitimate funds begin.

The newer criminal groups and leading terrorist organisations resemble modern legitimate business structures. The massive international illegitimate economy allows the illicit to operate with facility alongside the licit. The enormous discrepancies in regulation in a globalised world allow criminals and terrorists to exploit this lack of consistency to their advantage.

Moreover, many of the strategies which are presently applied to combat terrorism such as the following of money trails, freezing of assets, and safeguarding borders are also used to combat transnational organised crime.

\section{The ICC as a Human Security Instrument?}

Security is 'the condition of being protected from or not exposed to danger, a feeling of safety or freedom from or absence of danger' (Biscop and Coolsaet, 2003: 2). Security is seen as indivisible and is described as a comprehensive approach. Security is defined differently across continents and organisations. The Western European Union described a common concept of the security environment that highlights, among other things, the importance of the maintenance of international peace and order and the widest possible observance of generally recognised norms of conduct between states and of democratic institutions, respect for human rights and fundamental freedoms, and the rule of law (wEU Council of Ministers, I995).

Canada defines human security as 'freedom from pervasive threats to people's rights, safety or lives, i.e. freedom from fear as opposed to freedom from want, which corresponds to well-being rather than security' (Axworthy, I999: 9). Canada has identified five policy priorities: protection of civilians, peace support operations, conflict prevention, governance and accountability, and public safety. Like comprehensive security, human security highlights the interconnections between different dimensions of security and puts into evidence the global nature of security challenges.

In some countries, insecurity is seen in terms of terrorism and weapons of mass destruction. In other countries, insecurity is associ- 
ated with civil wars. In other parts of the world, it is seen in terms of poverty and organised crime activities. The global dimension of war situations and terrorism, demonstrated by Al Qaeda, has called for substantial cooperation and coordination. The very existence of an international society is, just as is the case with a national state, dependent upon the existence of shared norms and laws. It obliges international forums and states to:

- criminalise the provision or collection of funds destined to support the phenomena, prohibit persons from doing so and bring any perpetrator to justice, be it at the national or international level;

- freeze funds and other financial assets or economic resources of criminals or of the people who attempt, participate or facilitate illegal acts, including funds generated from property owned or controlled by them;

- refrain from supporting these criminals in any way (e.g. recruitment, safe haven, use of territory, permitting them to cross borders, forge documents, etc.);

- prevent the commission of illegal acts; and

- cooperate in criminal investigations and proceedings.

Just like a constitution in a national state, an international legal order is needed to ensure the legal equality of us all. It is obvious that the ICC plays an important role in this. Combating crimes against humanity implies another kind of warfare, one very different from that which uses the conventional military, judicial and other law enforcement agencies and bodies. The concept of security is in fact very broad, and demands a broad and well-equilibrated, multi-agency approach. The blurring of the lines between global and domestic has already had its impact. It is now widely recognised that when states become tormentors, instead of being protectors of individuals, the international community has the right and even the duty to take over in order to protect the individual man, woman and child from violence, abuse and injustice.

In July I 998, a Un conference adopted the Rome Statute of the ICC. The Rome Statute identifies the most serious violations of international human rights and humanitarian law for the purposes of exercising jurisdiction. These violations are grouped within the categories of genocide, crimes against humanity, war crimes and the 
crime of aggression. The Rome Statute defines the crime of genocide as any of the following acts committed with intent to destroy, in whole or in part, a national, ethnical, racial or religious group: killing members of the group; causing serious bodily or mental harm to members of the group; deliberately inflicting on the group conditions of life calculated to bring about its physical destruction in whole or in part; imposing measures intended to prevent births within the group; forcible transfer of children of a group to another group.

Crimes against humanity are defined as any of the following acts when committed as part of a widespread or systematic attack directed against any civilian population, with knowledge of the attack: murder; extermination; enslavement; deportation or forcible transfer of population; imprisonment or other severe deprivation of physical liberty in violation of fundamental rules of international law; torture; rape, sexual slavery, enforced prostitution, forced pregnancy; enforced sterilisation, or any other form of sexual violence of comparable gravity; persecution against any identifiable group or collective on political, racial, national, ethnic, cultural religious, gender or other grounds that are universally recognised as impermissible under international law; enforced disappearance of persons; the crime of apartheid; other inhumane acts of a similar character intentionally causing great suffering or serious injury to body or to mental or physical health.

War crimes are any of the following breaches of the Geneva Conventions of I2 August 1949, perpetrated against any persons or property: wilful killing; torture or inhuman treatment, including biological experiments; wilfully causing great suffering or serious injury to body or health; extensive destruction and appropriation of property, not justified by military necessity and carried out unlawfully and wantonly; compelling a prisoner of war or other protected person to serve in the forces of a hostile power; wilfully depriving a prisoner of war or other protected person of the rights of fair and regular trial; unlawful deportation or transfer or unlawful confinement; taking of hostages and violations extensively defined in Article 8, Subparagraph b, of the Rome Statute. In the case of armed conflict not of an international character, the Court's jurisdiction will cover breaches of Article 3 common to the four Geneva Conventions of I 2 August 1949. The Court will have jurisdiction over the crime of aggression once a provision defining the crime has been adopted. 
The Rome Statute contains no requirement that the assistance be either direct or substantial. Furthermore, incitement is limited to the crime of genocide (Art. 25, 3e). According to Article 25, ordering, soliciting or inducing any crime within the statute, which occurs or is attempted, constitutes criminal responsibility. The Statute defines the boundaries of complicity in a wide way, situating the net well beyond the principal perpetrators. The objective element requires little more than assistance, while the subjective element requires a purpose to facilitate the crime as well as the knowledge that the assistance will assist in the offence. The aim of ICC investigations is to identify the precise nature of the alleged criminal activity, to identify alleged suspects and potential witnesses including victims, and to investigate both incriminating and exonerating circumstances.

It is clear that many groups responsible for crimes that fall within the mandate of the ICC are involved in other forms of crime such as terrorist acts, illegal immigration, social and economic underdevelopment and organised crime. The latter phenomenon is due to the end of the Cold War, which produced a drastic change in security environments. In the absence of a major military threat, other factors can and will constitute the underlying causes of terrorism or of armed conflict between or within countries. These can intrinsically affect the values and interest of the ICC, as it is not difficult to predict further and more intense targeting of the civilian population. Most important to the ICC are financial support from illicit activity, organised crime groups operating as supporting networks, a common base of operations (functioning where the central state controls are at the lowest, where there are porous borders and weak law enforcement), the corruption of officials, the use and exploitation of information technology to maximise the effectiveness of their operations, the employment of specialists and experts, money laundering (especially via underground banking mechanisms) and other supportive illegal (weapons, false passports, etc.) activities. More intense targeting of the civilian population via an increasingly dense interaction between criminal, terrorist, and anti-humanitarian activities will be the result.

Nevertheless, it would be unjustified to criminalise all warlords and rebels as an ethnic group, or to consider them all as terrorists or key figures in international organised crime. But it is clear that many of them are heavily involved in criminal networks and activities, falling only partly within the strict mandate of the ICC. It becomes clear that 
situations that fall within the mandate of the ICC cannot be seen in isolation and that the ICC should not work in isolation. Therefore, it is interesting to explore the capabilities of the ICC when tackling criminal situations on an ad hoc basis.

Coalition building between national and international law enforcement agencies may guarantee more focused investigations and the promotion of better-coordinated investigation efforts, making full use of the available intelligence and evidence. There are also other concerns regarding the capacities of federal or international courts. First is the protection of intelligence information - especially in the middle of an ongoing conflict. Also, the capabilities to arrest and convict people in the middle of a conflict poses serious problems. Military capacities, which are deployed for peacekeeping as well as for peace enforcement purposes, are valuable tools for ending wars and may help to secure states in the aftermath of war and conflicts, but are not always ready to facilitate law enforcement actions. The same applies during post-conflict peace-building activities. Another problem is the tightly woven exclusion of probative evidence in traditional federal and international trials, limiting what can be placed before a court or a jury for evaluation.

Acting in accordance with Chapter viI of the un Charter, the Security Council can require the Court to defer investigations or prosecutions for a I2-month period, which is renewable. So investigations and prosecutions may be triggered by referral from the Security Council or a complaint from a state party. The office of the prosecutor also has the capacity to initiate investigations within territories that have ratified the statute, but there must be agreement from both the state where the alleged crimes took place as well as from the state where the accused is a citizen. The Court's relationship to the Security Council was one of the most contentious issues when the ICC was being created.

Ambiguities concerning the criminalisation of certain activities in regard to the ICC should be the subject of further exploration, especially when trying to acknowledge the seriousness of the disintegrating processes and the threat they pose to the social, economic and political future of the regions, which is the subject of any ICC involvement. Ultimately, the direct threats are the source of the most serious frustrations but not always sufficient to start investigations at the ICC level. International criminal law was regarded as more effective in addressing the relatively minor threats of local or regional group 
criminality. On the other hand, international criminal law offers limited capacity to diminish the threat of Al Qaeda. In the aftermath of their attacks, it has become obvious that the existing legal framework for bringing the attackers to justice is inadequate.

No less serious is the difficulty of the international legal framework to reach states that refuse to join multilateral agreements, precisely because they want to engage in the activities prohibited by the agreement. Some countries have placed themselves outside the bounds of new international developments. In May 2002, the Us administration took the unprecedented step of withdrawing its signature. The Us then embarked upon a crusade against the ICc. 'Unsigning' this treaty is unprecedented in international law and, in effect, would signal the intention to enter into conflict with the Court.

All of these problems can no longer be considered as separate phenomena. There is a need to better understand the links between these phenomena. Therefore, more energy should be invested in a more comprehensive approach, in further developing existing institutions, and in supporting and clarifying the role of new institutions such as the ICC. A central question is which crime situations should fall within the sphere of interest of the ICC in order to better evaluate the situations (potentially) under investigation. Not only is the definition of related crimes extremely important, but the criteria on which the selection of cases to be prosecuted is based also demand particular attention. Formal criteria currently include: the person to be targeted for prosecution, the nature and seriousness of the crime, policy considerations, and practical and other relevant considerations. Additionally, informal criteria such as showing that the tribunal is capable of bringing the persons before the court deserve particular attention.

When exploring possibilities to investigate arms trafficking, illegal financial transactions and money trails, other related forms of organised crime, and especially terrorist activities, the question concerning jurisdictional responsibility takes on additional significance. But international criminal law enforcement has not advanced to the extent that the various ad hoc tribunals and the ICC will be adapted to prosecute support and related criminal activities, because procedural difficulties have been and continue to be surmounted successfully.

Ad hoc international tribunals have not been as effective or as efficient as envisaged. Prosecuting senior officials for serious human rights crimes is a complex and expensive process regardless of 
whether the cases are tried before national or international courts. These prosecutions tend to involve massive amounts of evidence. These cases require a sophisticated prosecution strategy and trials must comply with international human rights standards to ensure their legitimacy and credibility. Cases brought before international criminal tribunals or in national courts (based on universal jurisdiction) are often tried far away from the crime scene and thus are less accessible to victims and to those in whose name the crimes were committed. These trials sometimes lack the visibility a local trial would have. The state where the crimes were committed, whose government may harbour accused war criminals, may oppose the prosecutions, resist cooperation and make it difficult to obtain custody of the defendants or obtain evidence. Gathering evidence for crimes that occurred hundreds or thousands of miles away makes it more difficult to meet the level of proof required for a conviction and for the accused to develop a comprehensive defence.

Another disadvantage of long distance includes a lack of familiarity with the cultural and historical context in which the crimes occurred. Bringing together judges, prosecutors, and other court personnel from different backgrounds and legal cultures creates obstacles to efficiency. Reconciling the civil and common law traditions to establish and implement rules of procedure and evidence is time consuming and costly. And by $200 \mathrm{I}$, steps to enhance international justice began to encounter growing political opposition. Unfortunately, the nine-eleven attacks further contributed to a shift away from support for international justice, with efforts to combat terrorism taking precedence over international law.

Questions regarding what to do with information collected by the ICC which is not of direct interest when prosecuting a case before the Court also arise: Can this information be used to facilitate prosecution of international criminals before other national or international tribunals? If so, how?

There is also the problem of sharing information among states, as well as in coordination with international institutions including Interpol, the Un Centre for International Crime Protection, the ICRC, the Council of Europe and other regional organisations (e.g. Europol), and international tribunals such as the ICTY and the ICTR. Most states, however, lack effective legislation in order to share information with the ICC if they are not directly involved in ICC investigations and cases. 
Use of information for treaty compliance and law enforcement poses a serious problem: how to maintain the confidentiality of that information. To successfully analyse accurate information requires that reporting parties, public and private, willingly divulge sensitive and valuable secrets. Resistance will mount if there are unanswered suspicions that the information is wrongly handled or released. The practice in the ICTY and the ICTR as well as that in the ICC will show to what extent international law enforcement is accepted and reinforced by all those concerned. It is surprising that in the report of the High Level Panel on Threats, Challenges and Change (Un Report, 2004), neither the role nor the importance of international law enforcement organisations such as the ICC are mentioned.

\section{Global Justice Remains a Dream}

Widespread violations of international humanitarian law have become a practice in the contemporary world: violent conflict is one of the biggest threats to security. In this world of global threats, global markets and global media, our security and prosperity depend on an effective multilateral approach. While measured use of force should not be precluded against the rulers of a country who have refused to cooperate with international justice, an open-ended war is ill-conceived, unjust and interminable. A different approach is needed, one in which legal categories recognisable under international law determine any use of violence in justified conditions. Any employment of military force in democratic societies is always a matter of political decision. Both NATO and EU history have illustrated that preventive engagement cannot start too early. One of the associated requirements, however, is the legal basis and procedural framework that will allow the establishment of clear and efficient command and control arrangements (Katseli, 2005).

Like in a national society, an international legal order is required to ensure the legal equality of all individuals. Growing concerns within the international community have resulted in a demand for international prosecution. With respect to criminal sanctions, the universality principle provides for jurisdiction both to prescribe domestic laws and to enforce sanctions against crimes or violations that have an independent basis in international law.

International justice has been elevated by the establishment of the 
ICC. Global defence and global justice should, however, be the subject of an integrated approach, facilitating better balanced interactivity between national and international forums, ensuring that serious violations of human rights, crimes against humanity and other serious forms of organised crime and terrorism become the subject of a structural and integrated preventive and repressive approach.

International law enforcement has not matured to the extent that the various ad hoc tribunals and the ICC will be adapted to prosecute support for genocide, war crimes and related crimes more effectively. First, procedural difficulties have to be surmounted successfully. In addition, international law may be under threat, but it is not at all certain that its role will be significantly undermined. In the meantime, the ICC has to continue to promote an open and cooperative attitude on a pragmatic basis. International lawyers, foreign experts and criminologists will increasingly have to become multidisciplinary in their vision and strategic planning; they need to be flexible in their ability to form alliances, and to construct methods to interact with each other and to develop their own networks, while deflating those of criminal groups. The UN must play a more central and systematic role against terrorism, and in post-conflict situations. Although the UN has often been pivotal in forging the international response to serious human rights crimes, the 'justice gap' underscores the need for more systematic UN efforts. There is a need for multitasking in global democratic leadership. To bring that about, there is also a need for a broader community of democracies in which 'weaker' countries take their place alongside the established democracies, acting in coalitions of the willing in those areas where they have something to contribute.

\section{Notes}

I See at the regional level e.g. the Communication from the European Commission to the European Parliament and the Council concerning terrorist recruitment; COM/2005/03 I 3 final.

2 www.iaea.org/NewsCenter/PressReleases/2002.

\section{References}

Alexander, Yonah., David Carlton and Paul Wilkinson (1979), Terrorism: Theory and Practice, Boulder, CO: Westview Press. 
Axworthy, Lloyd. (I 999), “Nato’s New Security Vocation”, Nato Review, No. 4, pp. 8-II.

Biscop, Sven and Rik Coolsaet (2003), The World is the Stage: A Global Security Strategy for the EU, KII B, Paris, Groupement d'Etudes et de recherches “Notre Europe”, Policy Paper, No 8.

Burgess, J. Peter (2007), “Critical Assessment of the Communication from the Commission to the European Parliament and the Council Concerning Terrorist Recruitment: Addressing the Factors Contributing to Violent Radicalisation (COM/2005/03 I 3 final)", Peace Research Institute Oslo.

Coolsaet, R. (2003), Global Governance: The Next Frontier, Brussels: кі в.

Coolsaet, R. (2005), Al-Qaeda: The Myth, Brussels: Kı в .

Deitelhoff, Nicole (2004), "The Transnational Construction of Legal Norms and Institutions”, Frankfurt amMain, Paper for the fifth Pan-European International Relations Conference, ECPR/SGIR, The Hague.

Delpech, Thérèse. (2002), "International Terrorism and Europe", Chaillot Papers, No. 56.

Dieben, Diede-Jan (2005), When Does War Become Crime? Aspects of Criminal Case Against Eric O., Centre for Migration Law, Nijmegen: Wolf Legal Publishers.

Human Rights Watch (2002), Erased in a Moment: Suicide Bombing Attacks Against Israeli Civilians, New York.

IAEA, Nuclear Safety Review for the Year 2005, GC (50) VINF/2.

Katseli, Louka T. (2005), "EU Policy Coherence on Peace, Security and Development: A New Agenda for Research and Policymaking”, Presentation for I I th EADi General Conference, 24 September 2005.

Keen, David (I998), “The Economic Functions of Civil Wars”, Adelphi Papers, No. 320.

Lejeune, Ph. (I998), “Anti-terrorism Policies: Legal, Ethical and Political Perspectives", Mercyhurst College.

Méndez, Juan (2002), "Human Rights Policy in the Age of Terrorism”, Saint Louis University Law Journal, No. 2, pp. 377-403.

Naim, Moises (2003), “The Five Wars of Globalisation”, Foreign Policy, No. I 34, pp. 28-37.

Ogata, Sadako, Amartya Sen, et al. (2003), Human Security Now: Final Report of the Commission on Human Security, New York; http://www.humansecurity-chs.org/finalreport.

Peleman, Johan (I998), "War Making and State Making: Behind the Scene in Kosovo and the South-West Balkans”, Pax Christie, Conflict Prevention Newsletter, No.I: I 5 .

Shelley, Louise (2004), The Nexus of Organised International Criminals and Terrorism, http://eu-ce-srvoo4/documentation. 
UN Report of the Secretary-General's High Level Panel on Threats, Challenges and Change (2004), A More Secure World: Our Shared Responsibility, New York,

UN A/59/56, www.un.org/secureworld.

UN Security Council (I992), Declaration of the President of the Security Council at a meeting of heads of state and government, www.un.org/Depts/dpa/repertoire.

WEU Council of Ministers (I 995), European Security: A Common Concept of the 27 WEU Countries, Madrid, I 4 November 1995. 



\section{Governing Transnational Law Enforcement in the EU: Accountability after Fusing Internal and External Security Monica den Boer}

Globalisation, new technology and increasing mobility have infused the transnationalisation of criminal activity. The perceived upsurge in international organised crime and terrorism has been mirrored by a further transnationalisation of law enforcement efforts, which means that policing, which can be performed at a variety of levels by a diverse array of actors, increasingly takes place across the borders of sovereign nation states. The organisation of transnational policing takes place both at the formal administrative level, as well as at the informal level where pioneering activities do not always fit the formal delineations of mandate and authority.

This implies that the transnationalisation of law enforcement whether by police, customs, immigration or national security officials - tends to be both vertically organised along formal 'top-down' levels of governance, as well as horizontally, along more informally organised networks and the exchange of information and intelligence. At the intersection between vertical and horizontal forms of transnational policing, new structures can be found, such as the EU Joint Investigation Teams.

Inside national states, policing gradually becomes a subject of 'distanciation' and 'responsibilisation' (Garland, 200I: I24). The responsibility for monitoring the security of different communities is increasingly shared between government authorities, private agents, quasi-governmental authorities and citizens; these can be seen as denoting emerging forms of 'multilateral policing' (Morgan and Newburn, I997; Crawford and Lister, 2004). Moreover, policing the 'post-modern society' involves a differentiated response to a rich and ever-changing diversity of communities and cultures. This requires 
considerable knowledge of local circumstances as well as a deep understanding of global (security) contexts.

The interactions between, on the one hand, vertical and horizontal transnational policing, and, on the other hand, local and global security demands, result in new tensions for the governance of policing. Structures of police agencies, styles of policing, training and employment of police officials, and the distribution of budgetary and logistic resources all become subject to stretching and squeezing movements. The unstable environment of policing is further challenged by the perceived need to centralise (or centrally coordinate) a certain number of policing functions, such as the criminal investigation of organised crime networks and the exchange of intelligence through electronic means.

Decentralisation is still promoted, however, to secure maximum accountability at the local level, to keep the governing distance at a minimum and to reflect the predominantly local nature of security (e.g. public order nuisance). ${ }^{\mathrm{I}}$ Hence, centralisation and decentralisation, which can actually be quite complementary in character, tend to be rhetorically reframed as opposite and competitive realities. When analysed from an empirical perspective, the centralisation of the governance of policing seems to be the dominant trend in some $\mathrm{EU}$ countries that maintain a deconcentrated or regionalised police organisation, such as the Netherlands and the United Kingdom (Den Boer, 2004b: 7). This centralisation trend is mainly related to the central management of policing issues, such as employability, information technology and capacity management. Moreover, in deconcentrated policing systems the need may arise to standardise working procedures, particularly when it concerns issues of a supra-local, regional, national or international level.

Finally, the governance of policing tends to be further challenged by the merging of internal and external security (Bigo and Leveau, I992; Anderson et al., I995: I 56f; Van Eekelen, 2004: I 27). In the recent past, at least until the end of the Cold War, governmental responsibilities for internal and external security were rather neatly distributed between different departments and agencies. 'Firewalls' existed and were cultivated between police agencies and internal security services on the one hand, and between foreign ministries, diplomatic services and the military apparatus on the other. Nowadays, and due to globally transmitting discourses about drugs, organised crime, illegal immigration and terrorism, formerly distinct 
bureaucracies tend to work together much more closely, even to the extent that defence personnel are now increasingly deployed for policing tasks, and vice versa. The merge between internal and external security can be detected in policy documents, such as those on the European Security and Defence Policy (ESPD). An example is a message from the High Representative of the Common Foreign and Security Policy (CF S P), Javier Solana, in which he argues that for the efforts to ensure stability in Europe, 'maintaining law and order and fighting organised crime are integral parts of our crisis management and conflict prevention throughout the Balkans' (Solana, 200I).

The European Security Strategy (2003) outlines a number of key threats, none of which have hitherto been situated neatly within the realms of internal security challenges. These key threats are: I) terrorism, with specific attention being paid to links with violent religious terrorism; 2) proliferation of weapons of mass destruction (WMD), with specific focus on NBCR weapons (nuclear, biological, chemical and radiological warfare); 3) regional conflicts, with focus on regional insecurity which can feed into WMD; 4) state failure, bad governance which is linked with or caused by corruption, abuse of power, weak institutions and lack of accountability, with the consequence of civil corrosion within; and 5) organised crime, which includes cross-border trafficking in women, illegal migrants and children, with the effect that state authority and state institutions run the risk of being undermined. None of these threats, so the document continues to argue, is purely military in nature: 'Each threat requires a mixture of instruments.... The European Union is particularly well equipped to respond to such multi-faceted situations' (European Security Strategy, 2003). One of the impacts of the implementation of this integrated, multidisciplinary security strategy within the EU confronts domestic and supranational police agencies with the challenge to collaborate with other security agencies. The security environment they are supposed to respond to becomes far more complex.

Table I clusters the main challenges to governance of policing, including transnationalisation and globalisation. New zones of security cooperation are established, which can have far-reaching implications for the level of professionalism and accountability with which the officials operate. In an era where civil liberties are under pressure as a consequence of the Global War on Terrorism, however, experimentation and pioneering should be monitored by state authorities, who are (still) best placed to be the guardian of the delicate balance between freedom and security. 


\section{Table 1 Pressures on the Governance of Policing}

$\begin{array}{lll}\text { Local Horizontal Decentralisation } & \text { Internal } & \text { Fragmentation } \\ \text { security policing } & \text { security } & \text { Pluralisation } \\ \text { concerns } & \text { Distancing } \\ & \text { Responsibilisation } \\ & ->\text { National governments } \\ & \text { in retreat }\end{array}$

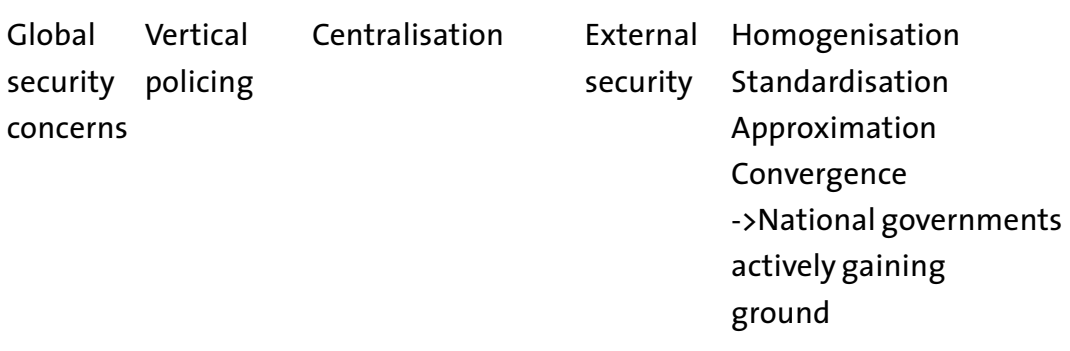

In this chapter, three relatively new forms of transnational law enforcement within the European Union (EU) shall be analysed on the basis of a set of variables: history and political raison d'être of transnational law enforcement; structure, composition, mandate and governance of transnational law enforcement; the legal context; and challenges from good governance criteria, in particular accountability. These variables will be applied to: I) EU police missions; 2) an integrated $\mathrm{EU}$ border management system in the form of a European border guard; and 3) EU anti-terrorism efforts within the framework of external relations and security policy. The good governance criterion of accountability is of particular importance for understanding the implications for a human security perspective within the EU. A dominant issue in policing is state-society relations: police forces operate on behalf of both governmental and societal interests, leading to the correction of individual and group behaviour. Every EU member state has achieved a specific balance in this respect, but with a wide variety of types: Spain, Greece, Portugal and the former Warsaw Pact countries, with their past dictatorial regimes, have quite different balances than the Nordic countries; some countries have state police, others do not. With the disappearing meaning of national borders within the $\mathrm{EU}$, and the transnationalisation of law enforce- 
ment, new national balances in the legitimacy of law enforcement have to be found. The development of accountability mechanisms shows how a balance is emerging in the Eu between the European/ national government and national/European citizens, which can be related to the criteria for human security (as normally applied in developing countries). So far, accountability falls far behind security governance.

\section{E U Police Missions}

In 200I, the EU member states agreed to deploy 5,000 police officials as of 2003 . A smaller number of them - a maximum of $\mathrm{I}, 000$ police officers - was to be rapidly deployable, which means that they should be made available within thirty days. In January 2003 , the EU started the first civilian operation under the auspices of the CFSP. It did so by establishing an EU Police Mission (EUPM) in Sarajevo. The EUPM in Bosnia Herzegovina officially started on I January 2003, when it took over from the Un International Police Mission, also called the UN International Police Task Force (IPTF). This Task Force had been building a 14,000 -strong professional multi-ethnic police force to replace the 40,000 political militias of the I $992-1995$ civil war. These developments followed the us veto within the Un Security Council of a six-month renewal of the UN I, 536-strong police force in Bosnia Herzegovina in order to mark us hostility to the International Criminal Court (ICC). Other members of the Security Council rejected a demand by the us government to make us soldiers immune to prosecution by the ICC. After the Us veto in the Security Council, the IPTF was granted an extra 72 hours in order to be disbanded. The EU took over.

The mission is part of a broad approach followed by the Eu and other actors with activities addressing the whole range of rule of law aspects. The EUPM has operated within the terms of the Dayton Agreement, which is the general framework agreement for peace in Bosnia and Herzegovina. The aim of the EUPM is to establish sustainable policing arrangements under Bosnia Herzegovina ownership in accordance with best practices and current standards that prevail in Europe and in international practice. With 550 international officers from more than 30 countries, 300 local staff and an annual budget of 38 million euros, the EUPM is much smaller than its UN predecessor, 
which had I,600 personnel and an annual budget of I 2 I million us dollars. Moreover, the IPTF enjoyed an operational mandate, while the EUPM does not. In spite of this, the EU PM covers a vast range of activities. These mostly concentrate on the monitoring, mentoring and inspecting of the operational capacities of the police in Bosnia Herzegovina, in the form of about 40 monitoring units. Moreover, the EUPM is to provide a secure environment for returnees (Mace, 2003).

The EUPM implements its work through five thematic and two institutional core programmes. The thematic programmes include public order and security, crime policing, criminal justice, internal affairs and public administration. These are designed to cover all aspects of police work, ranging from the maintenance of public order to the investigation and handling of evidence, and proper internal management and administration. The Criminal Police programme contains two sub-programmes: the fight against major and organised crime (MOC) and the fight and intervention against human trafficking (FIGHT). The EUPM officers support these programmes mainly through training, logistics and planning. One of the special mandates of the EUPM concerns the removal of non-compliant officers, in line with the police disciplinary procedures authorised by the High Representative; cases of non-compliance are to be pursued by the relevant domestic authorities. Once the domestic disciplinary procedure is completed, the case can be returned to the High Representative, who has the mandate not only to remove the non-compliant officer, but also his or her senior officer. This measure is to prevent obstruction of the peace process at senior levels. The absence of an appeal procedure is an interesting issue in view of legal-procedural accountability in extraterritorial police activities (Mace, 2003).

The EUPM works under the command of a police commissioner, who is hierarchically accountable to the EU High Representative and Secretary-General of the CFSP Council through the EU special representative, who is also high representative to Bosnia Herzegovina. The ESPD Political and Security Committee exercises political control and is responsible for the strategic direction of the mission (Mace, 2003).

There is also an Eu Police Mission in the Former Yugoslav Republic of Macedonia (FYROM), where police officers are helping to reform the Macedonian police force and bring it up to European standards, and where training on how to combat organised crime and trafficking in human beings is provided. 
The employment of civilian police officers within civil crisis-management operations demands a close cooperation between intimate strangers, that is, the ministers of foreign affairs, defence and the interior. The ES PD contains elements for both military and civilian crisis-management operations. This means that defence ministries and military organisations are also moving more towards semi-policing mandates. The Headline Goal 20I0, which was approved by the General Affairs and External Relations Council on I7 May 2004 and endorsed by the European Council of I7-I 8 June 2004, resolves to respond with rapid and decisive action, applying a fully coherent approach to the whole spectrum of crisis management operations covered by the Treaty of the EU. This spectrum, which should be read against the background of the adoption of the European Security Strategy by the European Council in December 2003, includes humanitarian and rescue tasks, peacekeeping tasks, tasks of combat forces in crisis management, including 'peace-making'. Naturally, the objectives of Headline Goal 20 Io will move into the police arena, especially when it concerns the establishment of joint civil-military cells within the Eums.

An illustration of the ever-growing merger between internal and external security is the new tasking of the military constabularies throughout Europe (Bigo, 2000; Lutterbeck, 2004). In the Netherlands, for instance, the Headline Goal 20 Io has amounted to IO3 officials from the Royal Military Constabulary (Koninklijke Marechaussee), which will be raised to $\mathrm{I} 53$ in 2006, and 30 civil police officers (Tweede Kamer, 2004). This capacity has not exclusively been offered to the $\mathrm{EU}$, but also to police missions of the UN, the Organisation for Security and Cooperation in Europe (OSCE), to NATO missions, and to multinational and ad hoc coalitions. Earlier civilian capability goals were agreed at the Göteborg European Council in June $200 \mathrm{I}$. Under this agreement the EU will provide up to 200 'Rule of Law' officials for crisis management operations: 72 judges, 48 prosecutors, 38 administrative officials, 72 penitentiary system officials and 34 others, 60 of whom have to be deployable within 30 days, and 43 provided for the purposes of fact-finding missions (European Council, 2002: I4). Also disaster aid teams of a total strength of up to 2,000 personnel can be deployed at short notice.

Meanwhile, within the EU there is also a number of bilateral and multilateral initiatives that could be interpreted as forms of enhanced security cooperation. An example is the French initiative to establish 
a multinational cooperation force, named the Force Gendarmerie Européenne (FGE), which should consist of 800-I,000 officials from the countries that harbour a gendarmerie force: France, Italy, Spain, Portugal and the Netherlands. This should respond to the demand for military police units that can operate in unstable situations. Regular military personnel is often not qualified to perform police tasks, while police officials are not qualified to perform executive operational powers. The FGE, however, can be used for law enforcement purposes in situations where the local police cannot be deployed. Moreover, the FGE could support local authorities to fight organised crime and to protect members of civil missions. The FGE is a typical example of a blue/green mixture, which, in the view of the policy makers, constitutes a contribution to civil and military components of a mission, or a facilitation of the transition between a military and civil mission.

By means of illustration: members of the Dutch Royal Military Constabulary have been deployed in Albania, Kosovo, Bosnia, Afghanistan and Iraq. They have been vested with responsibilities for civil policing (e.g. the support of local authorities, crowd and riot control, training) and military policing (disciplinary measures and law enforcement within the dispatched units to monitor investigation tasks). In practice, the Royal Military Constabulary concerns itself with civilian policing tasks. Participation is possible within the integrated police unit (IPU) and the specialised elements. An IPU is composed of staff, one or more operational police units, and a logistic support unit. A specialised element comprises one or more special teams. In line with the policy framework for international police missions, the officials can introduce specialised knowledge, for instance about forensic analysis or about border control. (Dutch) police officers can only be made available for non-executive civil policing tasks.

The increasing frequency and intensity of extra-territorial operations do raise the question concerning the regulatory qualification of these operations, even if they are not primarily accompanied by operational powers. As some precedents concerning the use of power by foreign military operations demonstrate, there are circumstances where the principle of neutrality may have to be suspended when active intervention between conflicting parties is required (Knoops, 2004: 606). Under the Spanish Eu Presidency in 2002, guidelines were drawn up for the command and control structure in EU police operations. Moreover, an EU concept for police planning was drafted 
and also concepts for police substitution missions. Furthermore, work was done on the selection and training criteria in the member states and the equipment criteria for police missions (Woolbridge, 2002). All of those were submitted to the Political and Security Committee (PSC) which falls under the ESPD structure. The guidelines were as such not the subject of scrutiny or decision making within the Justice and Home Affairs (JHA) Council, which normally deals with police matters.

It is interesting to observe that the ESPD bureaucracy is now also furnished with special police expertise. Already in 200I, Solana decided that - given the need for permanent involvement and support by experienced police experts - a police unit had to be established within the council secretariat, as part of the new political-military structures of the ESPD. The unit is headed by a police officer with international mission experience, and includes a core of police experts. It falls under the directorate that deals with the civilian aspects of crisis management within the new political-military structure, which underlines the 'EU's comprehensive approach to crisis management' (Solana, 200I).

One of the tasks of the police unit is to ensure that police work becomes integrated in the horizontal work on crisis management. Moreover, it has to manage the network between responsible services in the member states, international police organisations, ongoing police missions, and the experts in other international organisations such as the UN and the OSCE. Already in 200I, 3,500 police officers were deployed by EU member states in different missions, the bulk of which $(3,100)$ was present in the Balkans at the time (Solana, 200I).

If there is one aspect accentuated by the peace missions, it is that armed forces have undergone a shift from the traditional use of military force as war-fighting to that of law enforcement. From the military that participate in peace missions, it is expected that they engage in providing information, intelligence and evidence for use in courts. The regulatory context is hardly able to keep track of all these new developments.

Furthermore, what seems particularly worrying from an accountability perspective is that leadership and authority may be covered couched by foreign or alien authorities, and that professional competencies may be new, unknown or unregulated in certain environments. The Barcelona Report on Europe's security capabilities, A Human Security Doctrine for Europe ( 5 September 2003), has ap- 
propriately identified this lacuna and recommends that a new legal framework is to be devised 'to govern the decision to intervene and operations on the ground. This would build on the domestic law of host states, the domestic law of sending states, international criminal law, international human rights law and international humanitarian law' (Barcelona Report, 2003).

\section{European Border Guard}

Since the accession of ten new member states to the EU on I May 2004, the external border of the EU has changed considerably. In the south, Malta and Cyprus are now the most outward territories of the $\mathrm{EU}$. The more spectacular change took place at the eastern external border of the $\mathrm{EU}$, where the border was extended by 3,000 kilometres. It is generally assumed and agreed (but far from proven) that the displacement of the external border will give rise to new security problems, such as organised criminal networks and irregular migration. ${ }^{2}$ This puts a heavy responsibility on the shoulders of the new member states (House of Lords, 2003), in particular Poland, Hungary and the three Baltic states. These countries may be under pressure to relocate their staff and resources, and, moreover, the purpose and mission of the old-style border guards have generally shifted from preventing people from leaving the country to preventing people from entering the country. It was against this background that a political window of opportunity arose to put the control of external borders back on the agenda (Monar, 2003:3) after it had been buried following the failure of not having adopted the External Borders Convention.

To recap that history: in October 200I a group of countries under Italian leadership - Belgium, France, Germany, Italy and Spain - undertook a feasibility study on a European Border Police. The study was backed by the European Commission and largely financed under the EU Odysseus Programme. Other member states, including the United Kingdom, agreed that more cooperation on external border issues was needed, but expressed reservations about the idea of creating a European border police force. In a separate initiative, another group of countries (Austria, Belgium and Finland) organised a workshop on police and border security in November $200 \mathrm{I}$ that identified twelve areas to be developed within EU structures under the direction 
of the heads of member states' border guards (House of Lords, 2003). In December 200I, the Laeken European Council arrived at a carefully worded compromise on cooperation on external border issues. It gave the Council and the European Commission a mandate to work out 'arrangements for cooperation between services responsible for external border control and to examine the conditions in which a mechanism or common services to control external borders could be created'. The terms 'European Border Police' or 'European Border Guard' ultimately did not appear in the mandate.

In particular, the document by the European Commission (2002, 233 final) contains specific proposals concerning the integrated management of the external borders of the member states of the EU. The Schengen Agreements, absorbed into the 1997 Amsterdam Treaty on EU by virtue of a special protocol, had already laid down a standardised framework for the exercise of external border controls (see also Monar, 2003: If). These controls have been supported by the operationalisation of the Schengen Information System (SIS), by means of which border control officials have access to data on persons and objects, such as stolen or missing vehicles or identity documents. In addition, the Schengen Manual and the common Schengen visa list have introduced a level of standardisation in border control practices - be it for a limited number of member states.

On 7 May 2002, the European Commission presented to the Council and the European Parliament a Communication, entitled 'Towards an Integrated Management of External Borders'. The thrust of the Communication was that the Commission proposed a stepwise development instead of the direct institutionalisation that was thought of earlier. The phases foreseen by the document concerned the consolidation and codification of common rules and standards for external border controls; the creation of an external borders practitioners common unit and various other cooperation mechanisms; the creation of financial burden-sharing mechanisms; and a European corps of border guards. According to the House of Lords (2003), the reception of the Communication by the member states was broadly positive, but several member states rejected the Commission's view that integrated border management should ultimately lead to the creation of a European corps of border guards.

The Italian-led feasibility study on the creation of a European border police was submitted in May 2002 to the Spanish Presidency. This document proposed a complex network of national border po- 
lice forces, which would be linked by a number of important common elements such as special 'centres' as 'nodes' in the network, common units for special tasks, a common-risk analysis and financing mechanism, and a common curriculum. At the Seville European Council Summit on 2I-22 June 2002, illegal immigration was high on the agenda. The Council agreed on a plan for the management of the external borders of the member states, which was to be a more concrete implementation of the Tampere Action Plan adopted in 1999. Most elements of the Commission Communication were accepted, as well a few elements of the Italian feasibility study. The Council action plan contained a vague reference to a 'possible decision' on the setting up of a European corps of border guards, which would support but not replace national border police forces. Plenty of other issues related to an integrated border management, remained to be settled, however, including common operational coordination and cooperation mechanisms, a common integrated risk analysis, personnel and inter-operational equipment, a common body of legislation, and burden sharing between the member states and the Union.

The action plan envisaged the creation of 'common units' at particularly sensitive land and sea borders within five years. In this context, border guard officers of other member states could be vested with the competence to control persons and conduct joint patrols together with national officers. The action plan was approved in December 2002 on the basis of a report by the Committee on Citizens' Freedoms and Rights, Justice and Home Affairs. ${ }^{3}$

In the run-up to the EU Constitutional Treaty, the European Convention had been particularly clear about the setting up of a European border guard. Meanwhile, however, successive Eu Presidencies were actively working on the implementation of certain parts of the Seville Action Plan. The recommendation of the Commission to establish a common unit of external borders practitioners was expected to develop from the Strategic Committee for Immigration, Frontiers and Asylum (SCIFA) and was endorsed by the Seville European Council. scifa was set up following the Treaty of Amsterdam as a high-level expert group of immigration officials, reporting to the Committee of Permanent Representatives (COREPER), charged with taking a strategic view of immigration and asylum issues. 'SCIFA+' is the same group meeting with the heads of member states' border guards. The Seville Action Plan urged member states to 'introduce without delay, within the framework of the Council, the common 
unit for external border practitioners, composed of Member States' heads of border control, to coordinate the measures contained in the plan' (House of Lords, 2003: ch. 3, pt. 27).

The Danish Presidency then proceeded with the creation of the common unit under the existing formation of SCIFA+, with the remit of initiating operational forms of joint cooperation, approving a series of plans for joint operations and pilot projects submitted by the member states, and monitoring them. According to a progress report prepared by the Greek Presidency (2003), between July 2002 and March 2003, SCIFA+ approved the initiation of I 7 projects and set up a network of national contact points for the management of external borders.

In June 2003, at the Thessaloniki European Council meeting, the European Commission was invited to investigate the necessity of creating new institutional mechanisms, including the possible creation of a Community operational structure, in order to enhance operational cooperation for the management of external borders. According to the House of Lords $(2003)$ this appears to be a reference to the European border guard without actually naming it.

Several joint border control operations have been staged in the meantime. Moreover, interesting pilot projects have been initiated. One of these is a project for a common integrated risk analysis model (CIRAM), led by Finland with the aim of producing risk analyses. The initial stage involved ten member states, Norway, the European Commission and Europol. It has led to the establishment of a Risk Analysis Centre (RAC), which started working in Helsinki on I April 2003 to carry out common integrated risk assessments. Also, a common core curriculum for border guard training was set up, led by Austria and Sweden, in which all the member states and the accession states take part, together with Iceland and Norway. Austria presented a report to SCIFA in April 2003 on this project.

The current situation allows for considerable flexibility (Monar, 2003: 7f). A common feature of initiatives that have been employed thus far is that they are taken forward by individual EU member states with a varying participation from other EU countries. This soft form of integration allows member states to explore simultaneously different ways forward which, according to Monar (2003: 8), are complementary rather than mutually exclusive.

In June 2003, the European Commission (2003a) held that, in view of the operational management of projects in the field of external 
border control, an alternative institutional mechanism should be set up. At their meeting on 5-6 June 2003, the JHA Council approved of the establishment of a practitioners common unit (PCA), which was to deal exclusively with operational issues and would hold separate sessions from SCIFA. The PCA, following a decision by SCIFA, would promote in due time the introduction of a common core curriculum for border guard training and would examine the possibilities for further developing common operational patterns in border management.

Different models were discussed of how a European border guard should be shaped. Some member states advocated centralisation in view of the need for hierarchical and operational command, others favoured operationalisation as the essence of an integrated border management structure. Some others also emphasised the continuation of sovereign responsibility and the continuation of privileged partnership agreements, which are generally based on forms of bilateral or multilateral cooperation.

A centralised structure would have involved the creation of an integrated border guard force under the authority of the Council. It would have to be given a common command structure, common training and equipment standards, it would be financed through the EU budget and it would be vested with full law enforcement powers at the external borders. Eventually, such a structure could partially or totally replace the national border control authorities (Monar, 2003: 8). This centralised model would involve substantial legal changes and would impose a heavy demand on cultural-linguistic capacity, while the decentralised model (see below) is easier to implement, but constitutes a challenge to the uniform application of border control standards throughout the whole of the EU.

A decentralised, networked structure would imply a network of national border guards. This would be a reflection of the organisational model laid down in the Italian feasibility study. According to this model, national border guard authorities would continue to exist as normal, but they would (at least in part) be subjected to common instructions from a Council body. Training and equipment could be shared, and a contingency reserve could be established to act as a 'rapid response force' (Monar, 2003:9).

As in the case of the EU police missions, we can observe an increasing shift from formerly defence or military-oriented tasks to policing: 
'The current emphasis is for securing Europe's peripheries by means of security, rather than defence, measures. This means various forms of policing. Barriers to transnational policing remain, but the outer defences of a fortified Europe, policed by border guards, have now been established. This has occurred either by commission, such as tripartite agreements for operational cooperation between Hungary, Austria and Slovakia, or by omission, as in the case of borders with Ukraine where Cold War-era fortifications remain in place on Ukraine's Hungarian, Polish, and Slovak borders. But the language is different to what it was ten years ago, with the management of Europe's borders now being expressed in terms of internal policing rather than external military defence. Policing rhetoric has not necessarily established itself as a substitute for defence, or as a solution to conflict and instability in contemporary Europe, but it has marginalised defence as a model for securing Europe's peripheries.' (Hills, 2000).

In view of the expectation that a European border guard was going to be vested with coercive powers, which is very different from Europol (a non-operational agency), much remains to be desired in the area of accountability. As the House of Lords (2003) has observed, 'there could be legal problems in border guards exercising powers outside their own jurisdiction'.

Despite the fact that the European Parliament came out in favour of a jointly financed European corps of border guards (European Parliament, 2003), many member states continued to show resistance against a form of (centralised) institutionalisation. From a political point of view, the proposal to create an EU external borders practitioners unit was all 'hush-hush' and very low-key. This virtually ruled out any possibility to have a more profound, public debate about the rationale of such a new structure and about the potentially far-reaching impact it may have on human rights (Monar, 2003: I 5 ).

The EU Agency for the Integrated Management of External Frontiers formally started its activities on I May 2005 under the name Frontex. The agency is located in Warsaw and directed by the head of the Finnish Border Guard. 


\section{EU Counterterrorism}

Although counterterrorism is not a new policy issue within the $\mathrm{EU}$, it was resurrected as a leading policy issue. The terrorist attacks in the US on September II, 200I and in Spain on March II, 2004 unleashed an unprecedented wave of policy interventions within the $\mathrm{EU}$. The wide range of measures taken after the meeting of the EU Extraordinary Council on 2I September 200I was given new impetus after the attacks in March 2004, including the appointment of Gijs de Vries as EU Coordinator for Counter Terrorism, who was accountable to the Eu High Representative and Secretary-General of the CFSP Council, Javier Solana. With the renewed concern about terrorism, the dimension of foreign security and external relations has come to the fore far more prominently. Moreover, the link to Justice and Home Affairs as an 'international' security concern showed itself more clearly.

In the I990s, the CFSP pillar has played a less active role in the EU response against terrorism, mainly because of the difficulty in achieving consensus on operational matters. On the other hand, the Eu has been active on issues relating to cooperation between external intelligence agencies and longer-term matters relating to non-proliferation and arms control. A common response item was formed by the need to address the 40 counterterrorism response priorities that were set out in Us President Bush's letter of I6 October 200I to European Commission President Romano Prodi. The majority of measures, however, fell under the remit of the Third Pillar and the broader context of JHA. As far as the input of the Second Pillar is concerned, it should also be noted that the prevention of or the fight against terrorism is not included in the Petersberg tasks, which include humanitarian and rescue tasks.

The adoption of legal instruments, such as the Framework Decision on the EU Arrest Warrant, culminated in a series of profound changes in national criminal (procedure) laws. The principle of mutual recognition was embraced as the new recipe for the improvement of interoperability between the police and judicial authorities (Den Boer, 2003).

After nine-eleven, new EU structures were established. At the JHA meeting on 20 September $200 \mathrm{I}$, it was decided to establish a Counter Terrorists Experts Team (now referred to as the Counter Terrorist Task Force, CTTF) within Europol (JHA 3929/6/or rev 6, p. 5; Swal- 
low, 2004: 6). Although this provided a chance for Europol to make a significant contribution and raise its international profile, it proved difficult for the CTTF to make a genuine contribution. Partly, this was related to a deficient consultation process: the JHA decision was made without prior reference to, or consultation with, Europol, and it was not communicated to Europol once the decision had been made. Partly, the tasking - to collect all relevant information - went beyond Europol's remit, which explains the member states' reluctance to supply information. In 2002, the Europol management board set up a review team which established that the CTTF had accomplished its mission and could be disbanded (Swallow, 2004: 8f). One persistent question is whether the furbishing of supranational intelligence structures is complementary with intensified domestic intelligence gathering.

Though the anti-terrorism measures were predominantly JHA measures, the fact that some of those fell within the remit of external security concerns implied a considerable bureaucratic shift in the spheres of governance. This was unprecedented at the domestic level of the EU member states, and had several consequences for the level of democratic and judicial accountability. The range of actors now involved in interaction at the EU level expanded significantly, leading to the creation of new interagency networks. By virtue of the European Security Strategy and other leading political documents, it can be demonstrated that anti-terrorism became fully integrated in the sphere of external security and defence.

A first observation concerns the onset of a far closer cooperation between the internal security services and the foreign security and intelligence services. The heads of security and intelligence services were asked to meet on a frequent basis, and they were expected to include internal security agencies (such as MI 5 in the UK) and external intelligence agencies (such as MI 6 and the Government Communications Headquarters, GCHQ, in the UK). Their task was to make an inventory of legal competencies of the secret intelligence services in the field of anti-terrorism. Moreover, they were to improve operational cooperation between the member states and third countries (Den Boer, 2003: 202; JHA Council 200I).

Additional measures included the expansion of the network of counter terrorist liaison officers (CTLOS) who belonged to the police working group on terrorism (PWGT), which also includes non-member states such as Norway and Switzerland. The CFSP's counterter- 
rorism working party (COTER) and the JHA terrorism working group were to be expanded. Inter-organisational relationships were to be consolidated after nine-eleven by means of three-monthly joint meetings between COTER and the JHA working party on terrorism troikas. They also report to high-level transatlantic meetings (Gregory, 2003). Previously established bilateral and multilateral practices of information and intelligence exchange are unlikely to subside, implying numerous interactions that may go in different directions. As such, the EU's counterterrorism venue may well be characterised as a crowded policy area, which is mainly caused by a gradual and incrementalist form of policy making (Walker, 2000: $256 \mathrm{f}$ ).

With the increased involvement of and interaction with the national secret services, there has been a gradual insertion of a 'high policing agenda' into European security governance (Brodeur, I983). The former barriers between traditional policing functions and secret service activities are eroding, and this has (or should have) implications for the transparency and accountability of European law enforcement organisations (Den Boer, 2002: 279).

The boosting of the external security agenda through the renewed focus on counterterrorism is particularly visible in the transatlantic cooperation with the us and, to some extent, with Canada. The momentum opened up by nine-eleven was used for launching two agreements between Europol and the us to provide for the exchange of intelligence and personal data. To the surprise and outrage of parliamentarians and civil liberty groups, the agreement on data exchange failed to pass a proper parliamentary consultation, which would have been in accordance with the Europol Convention. Previously, the $\mathrm{EU}$ had not yet been able to enter into such an agreement because of the absence of a relevant data protection regime at the federal level of the Us.

Eurojust, the judicial counterpart of Europol, was also asked 'as a matter of priority' to consider starting up negotiations on similar agreements. Also, negotiations about mutual legal assistance treaties between the EU and the Us were conducted, mainly relating to the extradition of suspects to the Us. Differences in data protection regimes remained a hindrance in the cooperation. This meant that the FBI agent who was seconded to Europol only stayed for six months, and that law enforcement personnel from the EU working in the Us faced restrictions on their access to information in Us law enforcement agency files (Gregory, 2003). Nevertheless a first liaison office was 
opened in Washington, D.C. in August 2002. The EU and the us also concluded an extradition and mutual legal assistance agreement in 2003 (De Vries, 2004).

Other EU-Us issues included the continuation of a dialogue about a comprehensive convention on international terrorism. The EU Action Plan on Terrorism recommended a swift and efficient exchange of operational information on terrorist activities between the law enforcement authorities in the us and the EU. European and us law enforcement experts should meet regularly to share information on threat assessments in relation to preventive measures. Moreover, setting up specific joint EU-US investigation teams has been possible since 2003 (De Vries, 2004). These joint investigation teams are to be established with the participation of law enforcement officers from the US and one or more member states of the $\mathrm{EU}$ in order to investigate the financing of terrorism (e.g. by drug trafficking). First meetings were held in the framework of the Policy Dialogue on Border and Transport Security, where issues such as sky marshals and biometrics were discussed (De Vries, 2004). It was recommended that the US and the EU systematically share information on security measures in order to prevent terrorism, especially in relation to border control and law enforcement initiatives, as well as other investigation techniques relevant for the fight against terrorism.

The EU Coordinator on Counter Terrorism also announced that the external assistance dimension ought to be coordinated between the EU and the Us (assisting third countries to curb terrorism, especially by implementing UN conventions). Work on terrorist financing, weapons of mass destruction, and the criminalisation of proliferation activities is still on the agenda. It is hard to avoid the impression that the transatlantic axis against terrorism has opened the EU door to the us far more widely than before. Data protection rights are under pressure. The terrorist attacks in the us, Madrid and London have contributed to a new frame of mind that allows a relaxation of the use of personal data. An example is the use of biometrics under immigration law for the purposes of counterterrorism. Several worries have been expressed about the way in which intelligence is handled by overseas authorities, notably in the us. A European Commission proposal to store communication data of all $\mathrm{EU}$ citizens has also been met with considerable criticism.

The free movement of persons (especially second- and third-generation immigrants and immigrants with a temporary residence status) 
is increasingly restricted. Border control, visa issuing and passport control have all been subjected to more rigorous standards. Moreover, security levels have been raised significantly. These interventions - whether executed by state or private security authorities have a tangible effect on cross-border travelling. A discursive link seems to have been created between terrorism and asylum/immigration; the UNHCR commented, for instance, that under the new European arrest warrant procedures, a refugee could be transferred from one EU member state to another member state for prosecution.

Human rights organisations more generally have been dismayed about the speed at which the Council agreed to various measures: academics have pointed at the 'fragility of the human rights culture' (Bonner, 2002: 523). Criminal lawyers in particular are worried about the suspension of the presumption of innocence.

In summary, there may be plenty of considerations why parliamentarians, citizens and non-governmental organisations may be apprehensive about the spate of new anti-terrorism measures (Harlow, 2002: 45).

\section{Good Governance Requirements for Transnational Policing in the EU}

EU initiatives in the field of internal and external security are proliferating. Partly, this may be interpreted as a response to relatively new and global security challenges, such as transnational networked terrorism. But it can also be regarded as a concerted attempt to boost the identity of the EU as a security actor on the world stage. With the exception of the integrated border management system (and the future EU border agency), the initiatives discussed in this chapter are footed on intergovernmental cooperation, both within CFSP/ESPD and Justice and Home Affairs Cooperation.

Key office holders in the EU promote good governance and the rule of law for standardising transnational law enforcement practices, for instance for the use of force under international auspices (Solana, 2004: xi). Yet, the fact that these new initiatives are embedded within an intergovernmental governance context is paralleled by a deficient accountability mechanism. It has also been noted that the ' $\ldots$ problem of ensuring democratic accountability in the case of international engagements is not a feature unique to the deployment and use of 
military forces' (Hänggi, 2004: 5). The Barcelona Report (2003: 26) argues that in the field of European security policy, the democratic deficit is aggravated by the lack of transparency and a double deficit in parliamentary scrutiny. The degree of (national) parliamentary accountability with regard to (international) security affairs is limited and also differentiated across the Eu. Indeed, the trend of security management increasingly being vested in concepts such as 'collective security' or 'integrated security' makes it more difficult for formal political institutions in individual national states to exercise control over key policy issues that are at the same time subject to the dispersion of decision making across multiple territorial levels (multi-level governance), directly affecting individuals and groups in society (Greene, 2004: 22).

Parliaments may exercise various supervisory functions that may be able to compensate for some of those deficits: they can exercise legislative, budgetary, elective, representative and scrutiny powers (Hänggi, 2004: I 2). Work remains to be done, however, to coordinate the national and international systems that can guarantee legitimacy and accountability concerning the use of force under international auspices ( $\mathrm{Ku}, 2004: 50)$.

Several challenges in the field of administrative, legal and political accountability should be considered in the debate about the reform of security governance in the $\mathrm{EU}$. Some of the deficiencies in the currently fragmented accountability regime could have been overcome by the Eu Constitutional Treaty (Den Boer, 2004a). However, as long as law enforcement cooperation in criminal matters and foreign and security cooperation are not fully inserted into the area of EU Community decision making, that is, providing a prominent role for the European Commission, the European Parliament and the European Court of Justice, much remains to be desired concerning an even and mandatory application of good governance standards across the board of transnational law enforcement cooperation.

\section{Notes}

I See e.g. Evaluation of Dutch Police Act 1993 by the Stuurgroep Evaluatie Politieorganisatie, 'Lokaal verankerd, nationaal versterkt', www.politiebestel.nl.

2 Note, however, that the growth of transnational organised crime and uncon- 
trollable migration patterns is a global development rather than a strictly European one. May 2004 is not a meaningful turning point in this respect, not even for the $\mathrm{EU}$. Yet, the integration discourse successfully exploits the psychological dimension of $\mathrm{EU}$ enlargement in this respect.

3 European Parliament, www.europarl.europa.eu/facts/4_I I_3_en.htm.

\section{References}

Anderson, Malcolm, Monica den Boer, Peter Cullen, William C. Gilmore, Charles D. Raab and Neil Walker (I995), Policing the European Union, Oxford: Clarendon Press.

(Barcelona Report) Study Group on Europe's Security Capabilities (2003), A Human Security Doctrine for Europe: Report of the Barcelona Study Group on Europe's Security Capabilities, Barcelona, September I 5, 2003, available online: http://www.lse.ac.uk/Depts/global/Publications/HumanSecurityDoctrine.pdf; also published in: Glasius, Marlies and Mary Kaldor, Eds. (2006), A Human Security Doctrine for Europe: Project, Principles, Practicalities, London: Routledge, pp. 327-356.

Batt, Judy (2003), The EU's New Borderlands, London: Centre for European Reform.

Bigo, Didier (2000), "When Two Become One: Internal and External Securitisations in Europe", in Kelstrup, M. and M. Williams, Eds., International Relations: Theory and the Politics of European Integration, London: Routledge, pp. I72-I98.

Bigo, Didier and Rémy Leveau (I992), l'Europe de la Sécurité Intérieure, Rapport de fin d'étude pour l'Institut des Hautes Etudes de la Sécurité Intérieure, Paris.

Bonner, David (2002), “Managing Terrorism While Respecting Human Rights? European Aspects of the Anti-Terrorism Crime and Security Act 200 I", European Public Law, Vol. 8, No. 4, pp. 497-524.

Born, Hans and Heiner Hänggi, Eds. (2004), The 'Double Democratic Deficit': Parliamentary Accountability and the Use of Force Under International Auspices, Aldershot: Ashgate.

Brodeur, Jean-Paul ( 1983 ), "High Policing and Low Policing: Remarks about the Policing of Political Activities", Social Problems, Vol. 30, pp. 507-520.

Crawford, Adam and Stuart Lister (2004), The Extended Policing Family: Visible Patrols in Residential Areas, York: Joseph Rowntree Foundation / University of Leeds.

De Vries, Gijs (2004), European Strategy in the Fight against Terrorism and the 
Cooperation with the United States, csis European Dialogue Lunch, Washington, D.C., I3 May 2004.

Den Boer, Monica (2003), "9/I I and the Europeanisation of Anti-Terrorism Policy: A Critical Assessment”, Notre Europe, Policy Papers No. 6.

Den Boer, Monica (2004a), "Crime and the Constitution: Brief Chronology of Choices and Circumventions", Maastricht Journal of European and Comparative Law, Vol. I I, No. 2, pp. I43-I 58.

Den Boer, Monica (2004b), "Out of the Blue: Police Perspectives on Europe, Governance and Accountability", Politieacademie / Vrije Universiteit Amsterdam, www.politieacademie.nl.

Den Boer, Monica (2002), “Towards an Accountability Regime for an Emerging European Policing Governance”, Policing and Society, Vol. I 2, No. 4, pp. 275-289.

European Commission (2003a), On the Development of a Common Policy on Illegal Immigration, Smuggling and Trafficking of Human Beings, External Borders and the Return of Illegal Residents, СОм(2003) 323 final, 3 June 2003 .

European Commission (2003 b), Paving the Way for a New Neighbourhood Instrument, $\operatorname{COM}(2003) 393$ final, I July 2003.

European Commission (2003c), Wider Europe-Neighbourhood: A New Framework for Relations with our Eastern and Southern Neighbours, $\operatorname{COM}(2003)$ I04, I I March 2003.

European Council (2002), Document, IOI60/2/O2 REV2, CODSP I 88, Brussel, 22 June 2002, Presidency Report, Annex I, Rule of Law Capabilities Commitment Conference.

European Parliament (2003), Resolution of I 5 January 2003, TA-PROV (2003)OOI3.

Garland, David (200I), The Culture of Control, Oxford: Oxford University Press.

Greek Presidency (2003), Progress Report for the Implementation of the Plan for the Management of External Borders of the Member States of the European Union and the Comprehensive Plan for Combating Illegal Immigration, Council Document 7504/03, I7 March 2003.

Greene, Owen (2004), "Democratic Governance and the Internationalisation of Security Policy: The Relevance of Parliaments", in Born, Hans and Heiner Hänggi (Eds.), The 'Double Democratic Deficit': Parliamentary Accountability and the Use of Force Under International Auspices, Aldershot: Ashgate, pp. I9-32.

Gregory, Frank (2003), “The EU's Role in the War on Terror”, Jane's Intelligence Review, No. oI. 
Hänggi, Heiner (2004), “The Use of Force Under International Auspices: Parliamentary Accountability and 'Democratic Deficits'”, in Born, Hans and Heiner Hänggi (Eds.), The 'Double Democratic Deficit': Parliamentary Accountability and the Use of Force Under International Auspices, Aldershot: Ashgate, pp. 3-16.

Harlow, Carol (2002), Accountability in the European Union, Oxford: Oxford University Press, Academy of European Law, European University Institute. Hills, Alice (2000), Securing Europe's Peripheries: Border Guard Services in East-Central Europe, Working Paper, International Studies Association, www.ciaonet.org/isa/hiaor.

House of Lords Select Committee on European Union (2003), Proposals for a European Border Guard, I July 2003, www.publications.parliament.uk. JHA Council (200I), Conclusions, 20 September 200I, SN 3926/6/OI REV 6. Kelstrup, Morton and Michael Williams, Eds. (2000), International Relations: Theory and the Politics of European Integration, London: Routledge.

Knoops, G.G.J. (2004), “De (inter)nationaalrechtelijke betekenis en implicaties van geweldsinstructies voor buitenlandse militaire missies”, Delikt en Delinkwent, Vol. 43, pp. 602-62 I.

$\mathrm{Ku}$, Charlotte (2004), "Using Military Force under International Auspices: A Mixed System of Accountability", Born, Hans and Heiner Hänggi (Eds.), The 'Double Democratic Deficit': Parliamentary Accountability and the Use of Force Under International Auspices, Aldershot: Ashgate, pp. 33-50.

Lutterbeck, Derek (2004), "Between Police and Military: The New Security Agenda and the Rise of Gendarmeries", Cooperation and Conflict, Vol. 39, No. I, pp. 45-68.

Mace, Catriona (2003), "ESPD Goes Live: The Eu Police Mission in Bosnia and Herzegovina”, European Security Review, No. I6, http://isis-europe.org. Morgan, Rod and Tim Newburn ( I997), The Future of Policing, Oxford: Oxford University Press.

Monar, Jörg (2003), The Project of a European Border Guard: Potential, Models and Challenges, paper presented at the Geneva Centre for the Democratic Control of Armed Forces (DCAF), Workshop “Managing International and Inter-Agency Cooperation at the Border".

Solana, Javier (200I), EU Member States Police Capabilities for International Crisis Management, Message to EU conference of national police commissioners, Brussels, Io May 200 I.

Solana, Javier (2004), "Preface”, in Born, Hans and Heiner Hänggi (Eds.), The 'Double Democratic Deficit': Parliamentary Accountability and the Use of Force Under International Auspices, Aldershot: Ashgate, pp. xi-xii. Swallow, Paul (2004), Networks: The Contribution of the Police Working 
Group on Terrorism and Europol, mimeo, paper presented at workshop "European Law Enforcement Responses to International Terrorism”, 9-Io June 2004, Southampton, Police International Counter Terrorism Unit (PICTU) in partnership with the University of Southampton and the University of St Andrews.

Tweede Kamer der Staten-Generaal (2004), Inzet Nederlandse politie en Koninklijke Marechaussee bij internationale civiele politie-operaties, Brief van de Ministers van Buitenlandse Zaken en van Defensie en van Binnenlandse Zaken en Koninkrijksrelaties, Den Haag, 4 juni 2004, 27 476, nr. 6.

Van Eekelen, Willem (2004), "Decision-Making in the Atlantic Alliance and its Parliamentary Dimension”, in Born, Hans and Heiner Hänggi (Eds.), The 'Double Democratic Deficit': Parliamentary Accountability and the Use of Force Under International Auspices, Aldershot: Ashgate, pp. I I I-I 29.

Walker, Neil (2002), "Policing and the Supranational”, Policing and Society, Vol. I 2, No. 4, pp. 307-32I.

Woolbridge, Jamie (2002), "Progress in Building ESPD Capabilities”, European Security Review, Nr. I3, http://isis-europe.org. 



\title{
5 The Lack of Coherence between Internal and External Security Policies of the European Union
}

\author{
Cyrille Fijnaut
}

The structure of the European Union is often depicted as a temple with three pillars. The European Community forms the first pillar, the second relates to the Common Foreign and Security Policy (CFSP) and the European Security and Defence Policy (ESPD) of the European Union, and the third pillar encompasses police and judicial cooperation among the member states. The distinction between the Second and Third Pillars corresponds to a large extent to the classic distinction between foreign and internal security. According to Article I I of the Treaty on European Union (TEU), in which the goals of the CFSP are listed, security means first and foremost security of the Union in the international context. Nonetheless, in Article 29 TEU, which describes the main goal of the Third Pillar, security is above all the security of the citizens on the common territory of the member states with respect to crime (organised or otherwise) and specifically terrorism, human trafficking, drug trafficking and arms trafficking, that is, internal security (Denza, 2002).

However, as regards the European Union, the term 'internal security' must still be used with some reserve since Article 33 TEU explicitly states that the provisions of the title in question 'shall not affect the exercise of responsibilities incumbent on member states with regard to the maintenance of law and order and the safeguarding of internal security'. The term internal security in this treaty is in a sense reserved to the security of the citizens at the level of the member states, which is understandable in a quasi-federal union of sovereign states. With an allusion to the description of the EU's territory as 'an area of liberty, security and justice', it would be appropriate at this higher level to speak of 'homeland security' for the time being. Nevertheless, 
this description will of course not suit everyone's taste in the European Union due to its association with American terminology, especially not after September I I, 200 I.

This article criticises the incomplete way in which the European Union acknowledges the intertwinement of internal and external security agendas. The European Security Strategy (2003) defines risks and threats mainly as external in origin. From a human security perspective, these policy choices hamper a comprehensive approach. Furthermore, it is argued that in face of the reluctance to really empower EU agencies in the field of justice and police affairs, such an approach still has many hurdles to clear.

\section{Exporting Internal Security Practices}

At any rate, the 'pillarised' divide of the security policy that was formalised in the Treaty on European Union through the 1997 Treaty of Amsterdam has been artificial from day one. Are issues of external and internal security so strictly divisible as the pillar structure suggests? The artificiality of the distinction is to a certain extent acknowledged by the architects of these treaties. It is for good reason that the member states are instructed under Article 37 TEU to take standpoints 'within international organisations and at international conferences in which they take part' that they jointly agreed upon within the framework of the Third Pillar. Such a provision only makes sense if it is assumed that combating terrorism and organised crime within the Union's territory requires not only police and judicial cooperation between its member states and approximation of their criminal law - as Article 29 TEU provides - but also action against these phenomena by other countries either inside or outside Europe. But there is more than this provision. A point on which the Treaty is silent is that from its beginning in 1992 the European Union was seeking much more than structured international consultation on the approach to organised crime and terrorism. Gradually, the Union has taken the stand that dealing with these problems must be subject to specific foreign policy and thus a foreign policy that entails more than signing treaties and decrees.

As regards the first point (why is a specific foreign policy necessary?), for a clear understanding of the situation it must be pointed out that major forms of organised crime take place only within the 
territory of the EU (i.e. within the member states). An example is found in the extortion practices of the mafia of southern Italy. Nevertheless, it is true that a part of the smuggling variant of organised crime is carried out across the territorial borders of the $\mathrm{EU}$, that is, in both directions, not only into the member states. This is the case not only with illicit drug trafficking - heroin and cocaine are smuggled into the EU from other parts of the world, synthetic drugs are smuggled from the EU to other continents - but also with illicit arms trafficking. Human trafficking that takes the form of trafficking in women is a somewhat different phenomenon in that the women are largely recruited in countries outside the Union, but exploited in the EU - mostly, for that matter, with the cooperation of more or less criminal residents of the member states (Fijnaut and Paoli, 2004). As regards terrorism, it should also be pointed that significant manifestations of this phenomenon take place entirely within the borders of the EU's member states - as there is separatist terrorism in Spain, France and the U K. Islamic terrorism, in contrast, is obviously a form of terrorism that crosses the borders of the Union in both directions and worldwide. Both in the case of this kind of terrorism and in the case of a number of forms of organised crime, a foreign security policy is certainly in order to keep their occurrence on EU territory under control as far as possible (Fijnaut, Wouters and Naert, 2004).

With respect to the second point (the content of a foreign security policy), one must bear in mind that even before the signing of the Treaty of Amsterdam in the summer of 1997, the European Union made it known to the candidate member states (the so-called accession countries) and other European states that it was seeking more, much more, than signing international treaties and providing explanations of vote at international conferences, as is provided under Article 37. In September I 994 at a conference in Berlin, the ministers of justice and internal affairs of the member states and the accession countries agreed to further develop and intensify their mutual police and judicial cooperation in a number of ways with a view to combating organised crime more effectively. Furthermore, within the framework of the Octopus project that the European Union brought into being in 1996 in cooperation with the Council of Europe, the accession countries were not only obliged to reshape both their penal code and police laws along the lines of the Western European approach to this kind of crime, but also to reshape the organisation of their police forces, justice departments and customs to correspond as much as 
possible to those of the EU member states. In other words, the accession countries were confronted halfway through the I990s with a relatively hard-line EU foreign police and judicial policy. The policy was only officially endorsed by those parties involved in the 'PreAccession Pact on Organised Crime between the Member States of the European Union and the Applicant Countries of Central and Eastern Europe and Cyprus' from May I998 (Official Journal of the European Communities, 28 May I998, 98/C 220/0I).

\section{Intended Coherence between Internal and Foreign Security Policy}

Against this background, the Council and the Commission approved an action plan in December 1998 in Vienna in the context of implementing the provisions set out in the Treaty of Amsterdam on establishing the 'area of liberty, security and justice'. It should come as no surprise that it specified that in the domain of justice and internal affairs (i.e. a domain broader than combating organised crime and terrorism, thus including regulating asylum, immigration and integration) the Union would adopt a more ambitious position towards third countries and international organisations than had been the case until then (Official Journal of the European Communities, 23.I.I999, C I9/I-I 5). The message that the EU has to become a global actor in these domains was strongly confirmed in the programme approved in October I999 at a special summit of the European Council in Tampere (Finland) to enforce the Vienna action plan: 'The European Council underlines that all competences and instruments at the disposal of the Union, and in particular, in external relations must be used in an integrated and consistent way to build the area of freedom, security and justice. Justice and home affairs concerns must be integrated in the definition and implementa-

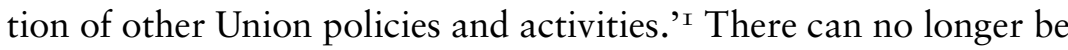
any doubt that the external policy of the Union must also be the underlying theme of its internal security and that, to that end, there must be a close coherence between external and internal security policies. This starting point - also influenced by the increasing threat of Islamic terrorism as it occurred on nine-eleven in the Us and on I I March 2004 in Spain - was frankly and radically expressed in the European Security Strategy: A Secure Europe in a Better World, adopted by the European Council on I 2 December $2003 .{ }^{2}$ 
In the context of this strategy, organised crime and terrorism are marked as key threats to the European Union, whether or not in relation to proliferation of weapons of mass destruction, regional conflicts and weak or failing states: 'Taking these different elements together - terrorism committed to maximise violence, the availability of weapons of mass destruction, organised crime, the weakening of the state system and the privatisation of force - we would be confronted with a very radical threat indeed' (European Security Strate$g y, 2003: 6)$. To ensure its security, the statement continues, the European Union must aim at three strategic goals (European Security Strategy, 2003: 7-8, 10):

- First, it is a matter of 'addressing the threats' and - unlike the Cold War period - this means the traditional notion of defence against a possible hostile invasion is no longer held. Rather, action of the Union is based on the idea that 'the first line of defence will often be abroad. The new threats are dynamic. The risks of proliferation grow over time; left alone, terrorist networks will become ever more dangerous. State failure and organised crime spread if they are neglected - as we have seen in West Africa. This implies that we should be ready to act before a crisis occurs. Conflict prevention and threat prevention cannot start too early';

- Second, it concerns 'building security in our neighbourhood': 'It is in the European interest that countries on our borders are well-governed. Neighbours who are engaged in violent conflict, weak states where organised crime flourishes, dysfunctional societies or exploding population growth on its borders all pose problems for Europe ... Our task is to promote a ring of well-governed countries to the East of the European Union and on the borders of the Mediterranean with whom we can enjoy close and cooperative relations';

- Third, effort must be made to develop an international order 'based on effective multilateralism': 'We want international organisations, regimes and treaties to be effective in confronting threats to international peace and security, and must therefore be ready to act when their rules are broken.' 
For the European Union security strategists, it is evident that these goals are not achieved solely through military, police and judicial means: 'spreading good governance, supporting social and political reform, dealing with corruption and abuse of power, establishing the rule of law and protecting human rights are the best means of strengthening the international order' (European Security Strategy, 2003: I I). Nevertheless, these means are very important in achieving these goals in a 'more active, more coherent and more capable' manner and in the context of a 'coherent foreign policy and effective crisis management' (European Security Strategy, 2003: I2). In this strategy paper, the military means are discussed in particular, but it also states: 'Better coordination between external action and justice and home affairs policies is crucial in the fight both against terrorism and organised crime. Greater coherence is needed not only among EU instruments but also embracing the external activities of the individual member states' (European Security Strategy, 2003: I 4).

It is remarkable however, that at the European Union level it is clearly difficult to express the coherence between internal and external security policies in words, and to put these two complementary policy forms coherently into practice. This applies, in any case, to combating organised crime and terrorism - the domain of security policy I am most familiar with. This is so because, although the development and execution of an integrated security policy was already stressed in Tampere in 1999, an adequate description of such a policy has not yet appeared. In addition, in the so-called Hague Programme, Strengthening Freedom, Security and Justice in the European Union, adopted on 5 November 2004 by the European Council as a follow-up to the Tampere programme (European Council, I 6054/04, JAI 559, Brussels, I 3 December 2004) such a description on the issue of security is expressly abandoned. The European Council left it, as far as this is concerned, at an appeal to the Commission and the Secretary-General of the European Council and High Representative of the CF SP, Javier Solana, 'to present, by the end of 2005 , a strategy covering all external aspects of the Union policy on freedom, security and justice, based on the measures developed in this programme to the Council. The strategy should reflect the Union's special relations with third countries, groups of countries and regions, and focus on the specific needs for justice and home affairs cooperation with them' (European Council, I6054/O4, JAI 5 59, Brussels, I 3 December 2004: 33). Given this situation, three general comments 
on the further development of such a strategy are in order, especially in the context of building a Human Security Doctrine as recommended to the EU's High Representative on CFSP, Javier Solana (see Barcelona Report, 2003; and chapter I of this volume).

\section{Necessity of a Sound Analysis of the Security Issues}

The first comment relates to the fact that it is very important to base this strategy on a sound empirical analysis of organised crime and terrorism (Islamic) in Europe and around the world. In the European Security Strategy (2003), the specific kind of crime and the specific kind of terrorism are mainly described as problems that threaten the European Union from the outside. This only partly corresponds with reality and is therefore significantly inaccurate. It is certainly true that the European Union is confronted with forms of organised crime and forms of terrorism that originate entirely or partly in parts of the world outside of the EU. However, it is no less true that the Union also faces serious forms of organised crime and terrorism that take place entirely on its territory and is also the source of forms of organised crime that spread worldwide. From a policy point of view, it is important to acknowledge the geopolitical complexity of both problems.

A first reason for acknowledging this complexity is that it forms a prerequisite for a policy that is intrinsically sound. Another equally important reason is that a denial of this complexity will easily evoke aversion in countries outside the EU to its external security policy regardless of its form, and certainly to a security policy in which those countries are considered to be the 'first line of defence' for the European Union. Why? On the one hand, because such a policy is based on the unquestionably inaccurate notion that the criminal harm threatening the European Union comes only from outside the Union and, thus, third countries, to a greater or lesser extent, are inadvertently held responsible for causing harm in the Union. On the other hand, because such policy justifiably raises serious suspicions that the implemented policy essentially only serves the security interests of the Union and does not help the security interests of the countries concerned and - following naturally from this criticism - will also soon be perceived as an unacceptable interference in internal affairs. If the European Union wishes to achieve an integrated security policy that will have long-lasting success, it will have to base this policy first and foremost on a sound, differentiated and balanced analysis of its security issues (Fijnaut, 2004a; Fijnaut and Albrecht, 2002). More- 
over, by denying or downplaying the way societal groups within EU member states contribute to these issues, the EU runs the risk of turning human security arguments into nothing more than rhetorical legitimisations of interventions (preventive).

\section{Ailing Connection External and Internal Security Policies}

The second comment is closely related to this. As mentioned above, in December 2004, the European Council ordered the European Commission and the Secretary-General to further develop the security policy while taking into account the relations that the Union especially in the domain of security, one may presume - already maintains with countries or groups of countries. This guideline is easy to understand. What has been achieved since I 994 cannot simply be disregarded; this is, all things considered, already quite substantial. Far-reaching policy measures were taken in the I990s as regards the accession countries: adapting legislation, reorganising services, cooperating with Union services (e.g. Interpol). The successive Justice and Home Affairs external relations multi-presidency programmes provide a more complete picture of everything that was included in the general domain of external security after the special Tampere summit in 1999. These programmes show that the scope of external security policy of recent years ranges from far-reaching reforms of the police forces and the criminal law practices in European states east and south of the EU, to negotiations with countries in North and South America and Asia about whether or not there will be local joint action against certain forms of organised crime and terrorism, to the organisation of so-called police missions in Bosnia Herzegovina and the Former Yugoslav Republic of Macedonia (FYRом) and, before long, also in the Democratic Republic of Congo that can be placed more or less halfway along this continuum. ${ }^{3}$ The ideas that are unfolding in the European Security Strategy about a safe Europe in a better world are thus coming from somewhere. It will therefore not be too difficult in the near future to provide a concrete interpretation of the Commission's recent proposal to systematically create links between the European Community's financial support of third countries and local measures in order to address 'regional or trans-border challenges such as organised crime, trafficking and terrorism' (European Commission, 2004: 3, I 2, I4).

A great problem in this context is the ailing connection between external and internal security policies. It relates to two issues. First, all 
important policy papers systematically neglect the question of to what extent the old and new member states' policy corresponds with the external security policy that the European Union has set out in its programme for the years to come, with a view specifically to combating cross-border forms of organised crime and terrorism on their own territory. Is, to use an example that is 'close to home', the organisation of the Dutch police sufficiently adequate to combat specifically the cross-border forms of trafficking in women and illicit arms? Secondly, little or no attention is given in these documents to organisations or the organisational facilities that, at the Eu level, must fulfil operational bridging functions in the active integration of the internal and external security policies. Concretely, this means agencies like Europol, Eurojust, the European Chiefs of Police Task Force, the Situation Centre within the Council, and the European Police College. Considering the current organisation and operation, the question that is at least legitimate is whether they are sufficiently equipped in terms of competences and/or means to fulfil such responsibilities adequately. Before the European Constitution was rejected this question seemed one of the first matters to be addressed by the Internal Security Committee (provided for by Article III-26I of the Constitutional Treaty) along with the existing Political and Security Committee under the Second Pillar and the European Commission (European Council, Presidency, Internal Security Committee, Brussels, 22 September 2004, I 2688/04 JAI ENFOPOL). Meanwhile, with the rejection of the Constitution, the EU reached a stalemate that implies continuation of the political and operational difficulties to implement a coherent policy that lifts the artificial boundaries between internal and external security concerns.

\section{Need forThorough Evaluation of Implemented Policy}

Now that organised crime and terrorism have become such central themes in the general policy of the European Union, the need is greater than ever before for a thorough evaluation of the policy implemented on these issues. At the moment, there is an evaluation of sorts of the security policy in and by the European Union - that is, in the shape of confidential evaluations by official commissions or private firms and very fragmented in the form of scientific research - but this evaluation not only does not measure up to the social importance of the problems at stake in this context, it also does not fulfil the requirements of openness, independence and thoroughness that can 
reasonably be expected. It is to be hoped that those who have to develop the integrated security policy of the European Union will make empirical research on the starting points, execution and results of this policy to a central part of the entire policy process. Nevertheless, it cannot be that ten to fifteen years from now the conclusion must be that nothing can be said with any certainty about the positive or negative effects of an integrated security policy on central issues like organised crime and terrorism - much like nothing sensible can be said at the moment about the effects of the policy that, since 1992, has been implemented under the Third Pillar on the scale, nature and development of organised crime and terrorism in and around the European Union (Fijnaut 2004b).

\section{Notes}

I Tampere European Council, I 5 October 1999, Presidency Conclusions, No. 59; http://europa.eu.int/council/off/conclu/oct99/oct99_en.htm.

2 http://ue.eu.int.

3 European Council, The Netherlands Presidency, JHA External Relations Multi-Presidency Programme, Brussels, 30 June 2004, JAI 25 5; ESPD Presidency

Report, Endorsed by the European Council of 17 December 2004, http://www.ue.eu.int.

\section{References}

(Barcelona Report) Study Group on Europe's Security Capabilities (2003), A Human Security Doctrine for Europe: Report of the Barcelona Study Group on Europe's Security Capabilities, Barcelona, September I 5, 2003, available online: http://www.lse.ac.uk/Depts/global/Publications/HumanSecurityDoctrine.pdf; also published in: Glasius, Marlies and Mary Kaldor, Eds. (2006), A Human Security Doctrine for Europe: Project, Principles, Practicalities, London: Routledge, pp. 327-356.

Denza, Eileen (2002), The Intergovernmental Pillars of the European Union, Oxford: Oxford University Press.

European Commission (2004), Proposal for a Regulation of the Council Establishing an Instrument for Stability, Brussels, 29.9.2004, СО (2004) 630 final.

European Security Strategy: A Secure Europe in a Better World, adopted by the Council of European Union, I 2 December 2003, http://ue.eu.int. 
Fijnaut, Cyrille and Hans-Jörg Albrecht, Eds. (2002), The Containment of Transnational Organized Crime: Comments on the UN Convention of December 2000, Freiburg: Max-Planck-Institut für ausländisches und internationales Strafrecht.

Fijnaut, Cyrille (2004a), De samenwerking tussen de Lidstaten van de Europese Unie bij de bestrijding van het islamistisch terrorisme, Leuven: Universitaire Pers Leuven.

Fijnaut, Cyrille (2004b), "Police Cooperation and the Area of Freedom, Security and Justice", in Neil Walker, Ed., Europe's Area of Freedom, Security and Justice, Oxford: Oxford University Press, 24 I-282.

Fijnaut, Cyrille and Letizia Paoli, Eds. (2004), Organized Crime in Europe, Dordrecht: Springer.

Fijnaut, Cyrille, Jan Wouters and Frederik Naert, Eds. (2004), The Use of Legal Instruments in the Fight against International Terrorism: A Transatlantic Dialogue, Leiden: Martinus Nijhoff. 



\title{
6 Ambidextrous Military: \\ Coping with Contradictions of New Security Policies
}

\author{
Joseph L. Soeters
}

Today's military operations increasingly take place in larger international contexts and their objectives have become vaguer (Elron, Shamir and Ben-Ari, I 999). Operations vary from war-like operations, emphasising the use of violence, to post-conflict nation-building in which communication with local people and NGOs is important. In addition, military operations have become more dependent on cooperation between civil services and national militaries. These demands put a heavy burden on the military, because they sometimes really contrast with the traditional military way of operating, stressing clear-cut goals, standard operating procedures, and a fairly strong degree of 'inner directness'. These changes reflect two aspects of the new policies for military action. First, there is a new logic of peacekeeping, implicitly - and sometimes explicitly - reflecting the shift from state security to human security. This means the military have to redefine their relations with their civil environment. Second, there is a new dimension to the old logic of multinational action: in contrast to the Cold War period, nowadays multinational forces are operative. This means the military has to redefine their internal loyalties.

In this chapter I explore how the military can cope with these new demands. I will start with two case studies regarding the cooperation between Dutch, German and British troops, respectively in Kabul and Cyprus. These case studies will show the contrasting requirements the troops are facing when being deployed in current operations. They will show that the traditional way of dealing with the situation is no longer appropriate. Thus, the military will have to change their habits and customs, at least to a certain degree. The military will need to be ambidextrous, which is being equally skilful in 
(seemingly) contradictory competencies. An ambidextrous way of working is not something only the military has to come up with. Business organisations too have been facing the need to cope with contradictory demands. Hence, the military can profit from theoretical insights that are developed in the business sector. These insights will help to formulate recommendations that may be conducive to the performance of the military in today's operations.

\section{Cooperation of Dutch Military with British and German}

Dutch units work increasingly alongside military personnel from other countries. This is not a coincidence. International military cooperation has become inevitable to enable militaries to deploy troops in peace operations in far-flung areas all over the globe (e.g. Soeters, Poponete and Page, 2006). This applies to all militaries, but it particularly pertains to militaries from relatively small nations such as the Netherlands. Apart from the structural cooperative arrangements in which the Dutch are involved, such as the first German/Netherlands corps, non-Article 5 crisis response operations increasingly take place in an international context. Examples include the UN Peacekeeping Force in Cyprus (UNFICYP) and the International Security Assistence Force (ISAF) in Kabul. During those missions, units of the Dutch Air Manoeuvre Brigade lived and worked intensely with first British and then German units. The UNFICYP and ISAF missions are not chosen at random. These are examples of missions during which international cooperation did not go as smoothly as one would have liked. Not every international cooperative mission is problematic, though. The Royal Netherlands Air Force (RNLAF), for example, has regularly participated in international operations (e.g. in Italy and Kyrgistan) during which the personnel successfully lived and worked with Belgians, Americans, Danes and Norwegians. It may be somewhat easier for air forces. Common aviation technologies (F-I6s, Apaches, or in general: helicopters) dictate how the work should be conducted, which acts as an ice breaker, or - to put it differently - as a 'cultural assimilator'. Studies have shown that technical professionals from different origins face relatively few difficulties in working together, because they speak the same 'language' and know exactly which goals they want to achieve (see e.g. Zabusky, 2000). Within the army technology is much simpler, but determining 
whether something has been effective is more complex, so there is more to discuss. That became apparent in Cyprus and Kabul.

In Cyprus, a Dutch company of the Air Manoeuvre Brigade was attached to and put under the command of a British regiment from I996-I999. From the very beginning there were disagreements with the British in the areas of discipline, punishment, fraternising with other ranks after work, ceremonial obligations, relations between men and women, working conditions, rules of engagement and a host of other issues (Soeters and Bos-Bakx, 2003). The Dutch, for instance, could not understand that a British commander punished all soldiers in a platoon for offences committed by only two members of that unit. In general, the degree of the penalties issued by the British officers in charge was much more severe than the Dutch servicemen were used to experiencing. In a small survey, the Dutch servicemen vented dissatisfaction and complaints about their interaction with the British. In addition to criticising the Brits, the Dutch servicemen also started to question the behaviour of their own officers because 'they were acting too much in the line of their British commanders ...'. Discussions got so heated that the Lessons Learned Office of the Dutch Army was ordered to find out what was going on and to find solutions. The result was a short report and a list of recommendations (distributed in a circular by the Lessons Learned Office) aimed at easing relations with the British military personnel, and especially the British officers. The recommendations included that the Dutch personnel needed to be aware that British officers generally expect to be treated with more respect than Dutch officers and that problems were to be handled by their own chain of command and legal channels. Furthermore, the list of recommendations stated that the Dutch should do their best in showing their professional military capabilities because that is what the British wish to see. According to reports, these recommendations seemed to have worked reasonably well during the remainder of the Dutch contribution to the mission.

Some commotion concerning German-Dutch cooperation arose in Kabul almost immediately after the start of the ISAF mission. The problems were not isolated to the camp, but were made public fairly quickly. In January 2003, various Dutch newspapers published articles about the cooperation between the Dutch and the German units, with headlines that left little to the imagination: 'Afghans aren't the problem, Germans are the problem ...' (Brabants Dagblad, I I January 2003 ). The army command launched an evaluation study in co- 
operation with the Lessons Learned Office, which showed that not one, but several, problems needed to be dealt with (Soeters and Moelker, 2003). The Dutch appeared to be unhappy with the fact that they were not in command. They felt slighted in the area of housing and task assignments and were dissatisfied with the security and safety policies issued by the Germans. In general, they thought themselves to be far more experienced in peace operations and, hence, they criticised the priorities set by the Germans. Finally, they were not very pleased with the inconsistent enforcement of the alcohol policy in the camp. As a result, some harsh words were spoken by Dutch servicemen in the interviews we conducted during an evaluation study: 'in the near future we don't want to have anything to do with (those) Germans again, not even maybe ...' Soeters and Moelker, 2003).

In addition, it was surprising that there was also commotion within the Dutch units themselves: the Air Manoeuvre personnel against the commandos, for example, and vice versa. Also, the Dutch military personnel in the headquarters of the multinational brigade were complaining about the behaviour of the Dutch Air Manoeuvre personnel. Revealing quotes from the interviews with Dutch staff personnel are as follows: 'those Dutch guys should quit bellyaching; if they have a problem, they should take it through channels; oh, yeah, and one more thing: those Airmobile guys should come out of their bar now and then and hang out with others' (Soeters and Moelker, 2003: 68). Exactly what were the problems?

\section{Strength and Weakness of Cohesion}

If someone takes a holiday on his own, s/he can make a lot of contacts. The same applies to a couple and also - but to a lesser degree to a family. It does not apply to the situation where three or four families go on vacation together. In that case, the members of the families have so much to do with one another and so much information to share, that there is no need for anyone from the outside. Contacts with outside the group are avoided, because they are simply not necessary. The group of three or four families becomes, as it were, an island within the greater whole of the campground, holiday resort or hotel. This phenomenon has been described by sociologist Mark Granovetter (1973; I 983) quite succinctly as 'the weakness of strong ties and the strength of weak ties'. 
In essence, the theory states that people who live in a close community have overwhelmingly homogenous contacts and have more friends than they have acquaintances. They are good in 'bonding', that is, they are strong in developing emotional solidarity or cohesion, to use the term more familiar to military personnel. 'Bonding' offers security and company. The result, however, is that people who live in close communities become somewhat parochial in their outlook and - in the jargon of social scientists - develop limited cognitive flexibility. People in close communities are less receptive to innovative ideas and are less open to other ways of thinking (Granovetter, I983). They are less able than other people to get things done in a broader context (society, the labour market, the organisation, the mission). That applies to things like getting a job, implementing innovative projects and acquiring influence generally. Within that larger whole, people in close communities form social segments, 'cliques' if you will, who want to have little to do with the outside world and who will reject that outside world if there are problems. An aspect of that rejection can consist of hostile 'blaming' gossip about the other groups in the immediate vicinity of one's own community (Soeters and Van Iterson, 2002).

In contrast, there are people - cosmopolitans - who have fewer friends but more acquaintances. Those are the people who are able to use their many 'weak ties' to get things done (Granovetter, I973; I983). Those weak ties act as bridges to other networks, units, departments or what have you. People with weak ties are good at 'bridging.' Thanks to their many weak ties, they know everything sooner, are also more open to new influences, and they are better able to exercise influence along a multitude of channels. Their contacts are less deep on the emotional level, and that aspect of living and work may be missed. But the variety of contacts makes up for a lot in terms of information, influence and status. Gossip in those constellations is more often informative and positive and, to the extent that it is critical about others, it is usually mild (Soeters and Van Iterson, 2002).

\section{Bonding and Bridging}

In Granovetter's original theory (1973), bonding and bridging are placed in opposition: it is a zero-sum game. The more there is of one, the less there is of the other, or: the one excludes the other. The ques- 


\begin{tabular}{|c|c|c|}
\hline & \multicolumn{2}{|c|}{ Bridging } \\
\hline & positive & negative \\
\hline 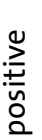 & ??? & $\begin{array}{l}\text { Dutch airmobile units during } \\
\text { UNFICYP and ISAF }\end{array}$ \\
\hline 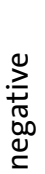 & $\begin{array}{l}\text { Augmentees / Individual staff } \\
\text { members during missions } \\
\text { abroad }\end{array}$ & $\begin{array}{l}\text { American units during } \\
\text { the Vietnam War }\end{array}$ \\
\hline
\end{tabular}

Figure 1: Cases of bonding and bridging

tion is whether that is correct (Gowricharn, 2003). Let me try to answer that question by designing a simple two-by-two matrix and apply it to military operations (figure I). Simply put, one can be good or bad in bonding, and one can be good or bad in bridging. It is possible to combine those options. If one is not good in both, then you have the situation that the us Army faced during the war in Vietnam (Gabriel and Savage, 1979). That type of situation is dominated by fragmentation and chaos, which occurred during that war as a consequence of the individual rotation system that was used to fill the units. In such a situation, people do not really attempt to develop indepth emotion-based contacts with one another, either inside or outside their own unit; hence there is neither bonding nor bridging. It is everyone for him- or herself - a situation army commanders must always try to avoid.

The situation in which people have few emotional ties but are able to maintain contacts of a businesslike, functional kind also occurs in everyday military practice. In this situation people are good in bridging but average to poor in bonding. That is, for example, the situation so-called augmentees - military personnel sent to operations on an individual basis rather than as part of a unit - find themselves in. Individual members of international headquarters will usually fit this profile. Such people predominantly fulfil liaison and brokering roles, hence, they have to make contacts with others, because without these bridging contacts their work would simply fail. In general, there are relatively few problems here, apart from the possibility that 
during the stay in the mission area one may easily develop feelings of loneliness, forlornness and stress related to performance pressures (Duine, I998:455). These are the emotional consequences of being a 'token', an individual facing a majority of other people (Moss Kanter, 1977: 206-24).

If we leave the dramas of Vietnam aside, the usual pattern during war is for cohesion within the unit to be strong, which implies that servicemen do not want to have anything to do with people outside their own unit. That seems a logical strategy for dealing with the enemy, but for comrades in one's own alliance (albeit from other units) it is somewhat less comprehensible. Yet, it is a familiar pattern within the military, as appears from the handling of the fatalities by the Americans during the Second World War. 'Those from our own battalion, our friends from our terribly close family of survivors, their deaths diminished us, but German dead didn't count at all - and men from other units didn't count as much' (Linderman, I997: 284). More recently, during the Iraq operations this phenomenon has again come to the fore. On several occasions, the us military have demonstrated going out of their way to rescue (fallen) members of their own squad, but they refuse to extend this solidarity to civilians, such as contractors, aid workers and the like (Samet, 2005). Again, during a war situation, this pattern of strong internal bonding with a negligible inclination towards bridging outwards is very functional. Shils and Janowitz (I948) showed this clearly with their analysis of the Wehrmacht. It is understandable why military commanders traditionally have put such a strong emphasis on internal cohesion, all the more in elite units with a 'strong culture'.

Internal cohesion, however, becomes less functional during a crisis situation when there are no clear friend-and-foe relationships, which is the case both in Europeanisation processes and human security policies. It also becomes different if service-people are put in a situation where they need to cooperate with other units and especially with units from other countries or local NGOs in order to carry out their activities. Both bonding and bridging are required during multinational non-Article 5 crisis-response operations and peace operations, such as UNFICYP and ISAF. Under those circumstances, the pattern of bonding without bridging clearly does not work as well, as appears from the vicissitudes described above. Similar observations concerning self-chosen isolation among the Dutch have also been reported with regard to interaction (lack of) with the military of other 
nations, for example from Turkey. Interestingly, the lack of interaction came from both sides (Soeters et al., 2004). These observations also stem from other peace operations such as the missions in Bosnia and Kosovo (Sion, 2004). It then becomes apparent that strong cohesion clearly also has shortcomings.

Basically, strong internal cohesion (bonding) is often accompanied by low trust in others (bridging). This phenomenon has serious limitations, as has also been described at the macro level of national societies (Fukuyama, I995). The limitations of low trust in others become particularly clear when the pressure and the threats are great (as in Kabul). Recent social-psychological studies have shown that those are the conditions that are ideal for generating hostile behaviour towards 'outsiders', even if those 'outsiders' are relatively close, such as people who belong to the same mission (Schimel et al., I999; Dechesne, Van den Berg and Soeters, 2007). This is particularly problematic, because especially in 'high risk', life-threatening conditions, heedful interrelating with others is the recipe for survival (Weick and Sutcliffe, 200I).

\section{Bonding plus Bridging}

In his original theory, Granovetter stated that there was no other way of looking at it: one can be good in bonding or in bridging, but not in both. The question is whether that really is so. There may be examples that bonding (internal) and bridging (external) do go together.

In the area of multicultural relations in society, the issue of bonding and bridging plays an important part. Minority groups can choose to be part of their own group before anything else. In that event they may, for example, buy a satellite dish to receive broadcasts from their countries of origin, and live in separate neighbourhoods. Or they can choose to integrate in the wider society with the help of training, work, hobbies and sport clubs, marry outside their own group and raise multicultural families. The impression may be created that there is no middle ground here. That, however, is not true.

In Hindu-Surinamese circles in the Netherlands, for example, it has been observed that some young people feel increasingly connected with their own original Hindu culture. ${ }^{\mathrm{I}}$ The young people meet during special dance evenings, they go to Bollywood films, they Internetchat with other Hindu youth in neighbouring countries like Great 
Britain and Germany and sometimes they wear traditional Indian clothing during parties and get-togethers. At the moment, this focus by young people from this population group living in the Netherlands on their Hindu culture (bonding) is stronger than it used to be. At the same time, these young people have turned more 'Dutch' than ever before, that is, much more 'Dutch' than their parents. They are better educated, fully integrated in the labour market and just as verbal and rude as ordinary Dutch young people. Apparently, these Hindu adolescents are quite able to build bridges with the rest of Dutch society. The Hindu-Dutch young people are not exceptional in this respect. Similar tendencies have been observed among Turkish and Moroccan youth in Western societies such as Belgium and the Netherlands, especially among more highly educated young women (Phalet and Swyngedouw, 2004: 205). It is possible to apply these observations to organisations, and therefore also to the armed forces.

In an evaluation of his theory ten years after the publication of his original work, Granovetter published a case study of a psychiatric hospital where bonding and bridging occurred simultaneously. As in many other hospitals, there were departments and specialisations, but, different from other hospitals, the interactions among the nearly 200 staff members were evenly distributed. Everyone was on a firstname basis, there were no homogeneous task groups and there were no cliques of personnel. The whole organisational structure was fluid and the roles and teams were always temporary. Granovetter (I983: 22I-223) interpreted this case study primarily as an example of the utility of bridging on the basis of weak ties. The fact that the hospital also had sub-networks based on specialisation and departments suggested, however, that there was also a bonding mechanism at work. Although Granovetter did not interpret the case this way, it is possible to consider this hospital, which was quite successful in terms of personnel turnover and morale, as an example of a successful combination of bonding and bridging.

It is worth the effort to strive for the same combination in the armed forces. The armed forces should continue to work on developing bonding within the units in order to ensure the survival of the muchpraised horizontal and vertical cohesion within units. That is especially important for operations under crisis conditions and during all-out war. At the same time, primarily leaders and trainers should develop a focus on military colleagues from other units, other services and other countries. That is important in connection with the in- 
creased mutual dependence during peacetime and during missions. It is also important because today smaller units such as platoons and companies are expected to be able to operate autonomously, including coordinating on their own with other partners, that is to say without coordination from higher authority. Hence, there is a need to 'take a look outside' also at this lower level. However, developing an external orientation and internal cohesion at the same time will not be easy.

One could try to get the troops to internalise that focus by consistently and persistently reinforcing it, both as trainer and as commander. This requires that extra attention should be given by trainers and commanders to the theme of cooperation. That would imply to emphasise the operational and mission objectives and the conditions that apply to everyone, as well as 'boosting' the other parties' status, such as by discussing the position of the others in a positive way (Winslow, Kammhuber and Soeters, 2004; Elron, Shamir and BenAri, 2003). One could also try to create this focus by taking a number of measures in the area of infrastructure, organisation and duty assignments. This could include giving instruction in mixed, interservice classes during training, housing personnel in 'mixed-unit' accommodation, exercising in mixed-unit configurations, joint policymaking, mounting joint patrols during peace operations, and joining at the mess after work or engaging in other joint social activities.

Combining bonding and bridging means that seemingly contradictory things are being done by the same people. Logically, that cannot be done at the same moment. If there is a lot of mixing of groups during work, it can be pleasant for people to retire to their own groups and messes during free time. If it is not possible to work in mixed groups, then the challenge is to get together during free time. During work, one could partly work with others, and partly with members of the own unit. However, if servicemen only interact with one another in their own groups and not with people from other groups, they will be unable to meet the contemporary requirements placed on them and their organisation. Especially since current military missions are increasingly life-threatening, it is important to continuously pay attention to others, to make others aware of possible dangers and, on the other hand, to be receptive to feedback and information from others (Weick and Sutcliffe, 200I). This can only be realised if the military themselves experience sufficient psychological safety not only in their own teams (Edmondson, I999), but also in their inter- 
action with others, even if they come from outside their own armed forces.

Combining bonding and bridging is not the only set of contradictory demands the military are facing nowadays. Like today's business organisations, the military needs to cope with many more contradictions, and they need to develop competence to deal with them.

\section{Ambidexterity}

Until not very long ago organisations were used to operating in one single context - national, institutional, technological - in one particular way, belonging to one particular type of organisational configuration (Mintzberg, I979). Organisations used to be good at one particular process, for example, mass versus batch production or production versus sales, like a football player who has a strong right leg or a strong left. But times are changing. Markets are expanding rapidly, technologies are becoming more complex, costly and risky, and high demands on the organisation are following each other in an increasingly faster pace. Organisations can no longer afford to develop long-term strategies because today's profitable insights will be tomorrow's obsolete losses. As a consequence, organisations need to resize and reshape continuously these days (Knoke, 200I). More specifically, to cope with these permanently changing conditions organisations need to be equally skilful in seemingly contradictory abilities. They need to execute today's operations and practices (exploitation), while developing simultaneously tomorrow's strategy and innovations (exploration). Organisations need to move quickly to new opportunities (adapting), whereas an equally important capacity is alignment, a clear sense of creating and delivering value in the short term. Those companies who are most successful in combining and balancing both competencies are most likely to survive the hyper-competition that is evolving in the world economy (O'Reilly and Tushman, 2004; He and Wong, 2004).

Organisations need to cope with many more sets of contrasting demands these days. Organisations nowadays are often forced to downsize their operational work force, while at the same time they feel urged to recruit new employees who will provide them with new knowledge and ideas. Organisations cannot evade collaboration with other organisations, but simultaneously they need to compete 
with them, albeit in different areas, products, technologies or elements in the value chain. Organisations may be successful in mass production and sales, but to be more competitive they will try to come up with niche-specialty branding. An example is the Swedish low-cost fashion retailer $\mathrm{H} \& \mathrm{M}$ asking top designers like Karl Lagenfeld, Stella McCartney and Victor and Rolf to craft a collection for their retail stores. Like piano players and percussionists who need to be equally skilful with their right and left hand and soccer players who try to develop their 'weak' leg, organisations nowadays need to be ambidextrous: good at dealing with contradictory demands at the same time. This unequivocally also applies to the military, being urged to combine bridging and bonding practices in today's peacekeeping missions. The military may profit from managerial ideas that have been developed in ordinary circumstances, and use those ideas in the exceptional situations they often find themselves in (Mintzberg, 200I).

In those exceptional situations the military faces many contradictory demands nowadays. The military needs to be ready for action, violent action if need be. At the same time they are requested to hold their fire - even to carry their weapon behind their backs - when they operate in peacekeeping missions in which talking to the people is more important than shooting (see e.g. Bos and Soeters, 2006). In fact, they should be prepared to shift from talking to shooting in a matter of seconds. A Dutch unit experienced this very clearly in Iraq in August 2004, when they were ambushed by 50 to Ioo warriors and were forced to immediately change their usual friendly attitude into real fighting and firing. Since the use of violence is a decreasing part of the military's job, the military should be prepared for all sorts of other tasks that society has put on their shoulders. These new tasks, such as civil-military cooperation and humanitarian relief, challenge the military in more than one way. As a consequence, like today's business firms, the military needs to obtain combinative capabilities in order to become ambidextrous. They need to be equally skilful in contradictory demands, which they have to cope with simultaneously. The question, however, is how they can learn to deal with this particular challenge.

In the management and organisation literature, two types of ambidexterity are distinguished: structural and contextual ambidexterity (Birkinshaw and Gibson, 2004). Organisations relying on structural ambidexterity tend to separate units or teams for either align- 
ment (exploitation) or adaptation (exploration). This way specialisation is enhanced, roles and tasks are well defined and the coordination of the organisation's activities takes place at the strategic apex.

Contextual ambidexterity, on the other hand, implies that individual employees divide their time between alignment-focused and adaptability-focused activities. These employees see their activities coordinated by people on the front line, which implies that their roles and tasks are relatively flexible, and they themselves need to have a relatively generalist attitude. These two 'solutions' may be helpful guidelines for the military to solve the problems accompanying the contradictory demands made upon them.

Structural ambidexterity would imply specialisation between a) units that focus on war-fighting, terrorist hunting and other activities that imply the use of violence, and b) units that concentrate on peacekeeping, Cimic activities (civil-military cooperation), nationbuilding and humanitarian relief. In this way one would have special forces on the one hand, and peacekeeping forces on the other. Every unit would be dedicated to specific tasks and all units would be separated from another, both in training and operations. Another option in this line of thinking is international specialisation, allowing the Dutch, for instance, to concentrate their resources on logistics and civil-military cooperation, whereas British troops would focus on special operations. A third option would be to have some kind of specialisation within a unit: in even the smallest groups one could have soldiers and officers who do the talking and others who take the initiative when hostilities and/or crisis situations arise.

Although in the near future some type of (international) specialisation in the armed forces will be unavoidable, this option has serious limitations. Specialisation decreases the flexibility of the operational resources, which is an important feature in today's organisations, the military in particular. Besides, this option assumes that operational conditions are either suited for special forces or for peace soldiers, for either 'shooters' or 'talkers'. This assumption will be violated over and over again, as experiences in Iraq and Afghanistan demonstrate every day. The very essence of the military's job is their competence in the control and the use of force, if needed. If in a certain situation violence is not in the air at all, other actors like NGOs or local authorities can do a better job.

Henceforth, in today's military, structural ambidexterity - although not impossible - seems to be less applicable and viable than 
contextual ambidexterity. In line with Birkinshaw and Gibson (2004) contextual ambidexterity emphasises that military personnel, especially commanders at all levels, need to be generalists. They need to have a broad view of their work, being culturally intelligent (Triandis, 2006) as well as being alert to opportunities and challenges beyond the confines of their own jobs. They need to act like brokers, always looking to build internal and external linkages, and if needed they have to be comfortable wearing more than one 'hat'. Most of all, they need to be able to immediately switch from communicating and negotiating to the actual repelling and use of violence.

To make sure that commanders at all levels obtain such a broad view of their work, the military should explicitly start paying attention to these features. They should do so in their training programmes as well as in their decision-making processes concerning who will be promoted to the higher ranks. Only the 'ambi-apt' commanders should arrive at the organisation's top, because they are the ones who can shift and display the mental flexibility that is needed so much in today's military. Today's military can do with nothing less.

\section{Note}

I I have borrowed this observation from Prof. Dr. Ruben Gowricharn (University of Tilburg), who himself is a member of the Hindu-Dutch population group.

\section{References}

Birkinshaw, Julian and Christina Gibson (2004), "Building Ambidexterity into an Organization", Harvard Business Review, Vol. 82, pp. 47-5 5.

Bos, Geesje and Joseph Soeters (2006), "Interpreters at work: experiences from Dutch and Belgian peace operations”, International Peacekeeping, Vol. I3, pp. 26I-268.

Dechesne, Mark, Coen van den Berg and Jo Soeters (2007), "International Collaboration under Threat: A Field Study in Kabul”, Conflict Management and Peace Science, Vol. 24, No. I, pp. 25-36.

Duine, J. (I998), “Werken en leven in HQ SFOR”, Militaire Spectator, Vol. I67, pp. $45 \mathrm{I}-455$.

Edmondson, Amy ( I 999), "Psychological Safety and Learning Behavior in Work Teams”, Administrative Science Quarterly, Vol. 44, pp. 350-383. 
Elron, Efrat, Boas Shamir and Eyal Ben-Ari ( I 999), “Why Don't They Fight Each Other? Cultural Diversity and Operational Unity in Multinational Peacekeeping Forces", Armed Forces and Society, Vol. 26, pp. 73-98.

Elron, E., Nir Halevy, E. Ben-Ari and Boas Shamir (2003), "Cooperation and Coordination Across Cultures in the Peacekeeping Forces: Individual and Organizational Integrating Mechanisms”, in: Britt, Thomas W. and Amy B. Adler, Eds., The Psychology of the Peacekeeper: Lessons from the Field, Westport: Praeger, pp. 26I-282.

Fukuyama, Francis (1995), Trust: The Social Virtues and the Creation of Prosperity, New York: Free Press.

Gabriel, Richard A. and Paul L. Savage (1979), Crisis in Command: Mismanagement in the Army, New York: Hill and Wang.

Gowricharn, Rubin S. (2003), "Sociale cohesie en culturele diversiteit”, Bestuurskunde, Vol.I 2, pp. 344-353.

Granovetter, Mark S. (I973), “The Strength of Weak Ties”, American Journal of Sociology, Vol. 78, pp. I360-г 380 .

Granovetter, Mark S. (1983), “The Strength of Weak Ties: A Network Theory Revisited", Sociological Theory, Vol. I, pp. 20I-233.

$\mathrm{He}, \mathrm{Zi}$-Lin and Poh-Kam Wong (2004), "Exploration vs. Exploitation: An Empirical Test of the Ambidexterity Hypothesis", Organization Science, Vol. I 5 , pp. $48 \mathrm{I}-494$.

Knoke, David (200I), Changing Organizations: Business Networks in the New Political Economy, Boulder CO: Westview Press.

Linderman, Gerald F. (1997), The World within War: America's Combat Experience in World War II, New York: Free Press.

Mintzberg, Henry (1979), The Structuring of Organisations: A Synthesis of the Research, Englewood Cliff, N.J.: Prentice Hall.

Mintzberg, Henry (200I), "Managing exceptionally”, Organization Science, Vol. I2, pp. 759-77I.

Moss Kanter, Rosabeth (I 977), Men and Women of the Corporation, New York: Basic Books.

O'Reilly, Charles. and Michael L. Tushman (2004), “The Ambidextrous Organization”, Harvard Business Review, Vol. 82, pp. 74-8I.

Phalet, Karen and Marc Swyngedouw (2004), "A Cross-Cultural Analysis of Immigrant and Host Values and Acculturation Orientations", in: Vinken, Henk, Joseph Soeters and Peter Ester, Eds., Comparing Cultures: Dimensions of Culture in a Comparative Perspective, Leiden/Boston: Brill, pp. I8 I- 208. Samet, Elizabeth D. (2005), “'Unburied and Unwept': Rereading the Trojan War for the Twenty-First Century", Armed Forces and Society, Vol. 3 I, pp. $623-649$. 
Shils, Edward A. and Morris Janowitz (1948), "Cohesion and Disintegration in the Wehrmacht in World War II", Public Opinion Quarterly, Vol. I2, pp. 280-3 I 5 .

Schimel, Jeff, et al. (I999), "Stereotypes and Terror Management: Evidence that Mortality Salience Enhances Stereotypic Thinking and Preferences”, Journal of Personality and Social Psychology, Vol. 77, pp. 905-926.

Sion, Liora (2004), 'Changing from Green to Blue Beret': Dutch Peacekeepers in Bosnia and Kosovo, Ph.D. dissertation, Vrije Universiteit Amsterdam.

Soeters, Joseph and Ad van Iterson (2002), "Blame and Praise Gossip in Organizations: Established, Outsiders and the Civilising Process”, in: Van Iterson, Ad, et al., Eds., The Civilised Organization: Norbert Elias and the Future of Organization Studies, Amsterdam/Philidelphia: John Benjamins, pp. 25-40.

Soeters, Joseph and Miepke Bos-Bakx (2003), "Cross-Cultural Issues in Peacekeeping Operations”, in: Britt, Thomas W. and Amy B. Adler, Eds., The Psychology of the Peacekeeper: Lessons from the Field, Westport: Praeger, pp. 283-298.

Soeters, Joseph and René Moelker (2003), “German-Dutch Cooperation in the Heat of Kabul”, in: Kümmel, Gerhard and Sabine Collmer, Eds., Soldat-Militär-Politik-Gesellschaft, Baden-Baden: Nomos, pp. 63-75.

Soeters, Joseph, Erhan Tanercan, Kadir Varoglu and Unsal Sigri (2004), “Turkish-Dutch Encounters in Peace Operations”, International Peacekeeping, Vol. I I, pp. 354-368.

Soeters, Joseph, Christina Poponete and Joseph T. Page (2006), "Culture's consequences in the military”, in: Britt, Thomas W., Amy B. Adler and Carl Andrew Castro, Eds., Military Life. The Psychology of Serving in Peace and Combat, Westport/London: Praeger Security, pp. I3-34.

Triandis, Harry C. (2006) "Cultural intelligence in organizations", Group and Organization Management, Vol. 3 I, pp. 20-26.

Weick, Karl E. and Kathleen M. Sutcliffe (200I), Managing the Unexpected: Assuring High Performance in an Age of Complexity, San Francisco: JosseyBass.

Winslow, D., Stefan Kammhuber and Joseph Soeters (2004), "Diversity Management and Training in Non-American Forces", in: Landis, Daniel, Janet Bennett and Milton J. Bennett, Eds., Handbook of Intercultural Training, Thousand Oaks: Sage, pp. 395-4I 5 .

Zabusky, Stacia E. (2002), "Boundaries at Work: Discourse and Practices of Belonging in the European Space Agency", in: Bellier, Irene and Thomas M. Wilson, Eds., An Anthropology of the EU: Building, Imagining and Experiencing the New Europe, Oxford: Berg Publishing, pp. I79-200. 


\section{PART III}

Human Security Policies from Below 



\title{
7 Human Security, the Military and the (Israeli) State: 'In-Between Organisations' at Checkpoints
}

\author{
Eyal Ben-Ari
}

In this chapter I will examine two organisations that have emerged during the current conflict between Israelis and Palestinians and that centre their activities on the checkpoints that are situated between Israel and the West Bank. For Israeli forces these places have a security function to weed out potential Palestinian perpetrators of violence. For Palestinians they are places of daily humiliation and degradation manned by stern occupying forces. For Israeli soldiers they are highly emotional places veering between fear and boredom, between anxiety and dullness. For the Palestinians, these are places of no less intense mortification and dread of arbitrary and inexplicable decisions. Indeed, the vast majority of Palestinians perceive the checkpoints as 'the' symbols of the occupation, of aggression, and of humiliation (Ben-Ari, Maymon, Gazit and Shatzberg, 2005).

The first organisation I examine is comprised of 'Volunteers on the Seam-Line' which is the official designation of what in Israel are popularly called 'humanitarian officers'. The deployment of these people began because of the disorder that characterised the checkpoints during the first two years of the current Intifada (since 2000) and which included frequent shooting in the air to gain military control, hitting and abusing Palestinians, and a general lack of shelters and infrastructure. As a consequence, a few reserve officers from the Israel Defence Forces (IDF) came up with the idea of trying to change the situation. The IDF agreed to a project which began in March 2002 within which reserve officers (later also non-commissioned officers, NCOs) volunteer for ten to fourteen days of service and function as sort of 'arbitrators' in regard to who can move through the checkpoints and who cannot. 
The second organisation is a human rights movement called MachsomWatch. The movement was established during the first year of the conflict in response to repeated reports in the press about human rights abuses of Palestinians crossing checkpoints. Volunteers from this exclusively women's movement attend checkpoints in small groups of two to four members, observe what is going on, document their observations and report - in text and pictures - to external bodies such as media representatives and their website. ${ }^{\mathrm{I}}$ They, too, often act as mediators between Palestinians and soldiers.

I focus on these two organisations in order to examine what might be termed 'human security from below'. I do so because much of the scholarly and policy-making literature about human security is still very much at the polemic stage. It is declarative in nature. I propose that these two cases, while not strictly human security operations, do carry some important lessons in regard to many of the difficulties, potentials and unintended consequences of the links between military forces, human rights and humanitarian organisations and civilian populations. More concretely, given the nature of the IDF current military deployment, the influence of human rights movements monitoring many aspects of the conflict, and the occasional military policy of trying to win the hearts and minds of the Palestinians (without much success), these cases bear similarities to some of the scenarios envisaged by proponents of human security.

My contention is that in response to the administrative difficulties and the human rights violations at the checkpoints, the Israeli army has either developed or allied itself with two kinds of hybrid organisations: the humanitarian officers who (as reservists) are both civilians and army personnel, and members of MachsomWatch who (being Jewish women) can act as mediators between the conflicting parties. While MachsomWatch operates from the outside and humanitarian officers from the inside of the military establishment, both end up, perhaps ironically, fulfilling similar roles. The strength of these differing hybrids lies in their ability to perceive the needs and views of the Palestinians and to 'translate' them into concrete suggestions that the military can take into account at the checkpoints. However, these two organisations are unintentionally transformed through their very actions: MachsomWatch has changed from a human rights movement into a humanitarian organisation and humanitarian officers have become a sort of 'lobby' group for the Palestinians. To be sure, I am not arguing that these organisations are unqual- 
ified success stories but rather that these cases are indications of the new relations between the IDF and various social movements centred primarily on humanitarian issues (and to a very limited extent on human rights).

\section{Human Security, the Military and Civilian Organisations}

The governing idea at the basis of human security policies centres, as I understand it, on an integrative perspective. Thus for example, a select committee reporting in the Barcelona Report to EU High Representative for Common Foreign Policy and Security Policy, Javier Solana, states:

'Some would describe the kind of operation that supports human security as humanitarian intervention. However, the term "humanitarian intervention" implies a purely military approach. The Ess [European Society for Security] emphasises that 'military instruments may be needed to restore order' in failed states and regional conflicts, but alongside humanitarian assistance, effective policing, civilian crisis management as well as broader political instruments ... A more holistic approach is needed that covers the different types of political institutions and different phases of conflict or state failure' (Barcelona Report, 2003: I I).

Similarly, the Amman Roundtable on Human Security (2004: 3) states:

'In an era of asymmetrical warfare and global media, ordinary citizens are becoming victims and combatants. State security structures are adjusting to the terrorist threats, but this reactive approach is proving inadequate. The time has come to build frameworks for human security: to engage with insecurity's systemic causes and involve nonstate actors working to transform conflicts and other obstacles to human flourishing.'

A central element in human security involves the role of the military. Thus within human security, the Bologna Report argues, military operations: 
'... are somewhere between classic peacekeeping and classic military intervention but different from both. Classic peacekeeping operations were based on the notion of keeping the peace between armed combatants. Generally ... to monitor cease-fires and separate warring parties. Even more recent peace support operations ... have not always protected civilians against human rights violations. Classic military interventions ... have been aimed at defeating an enemy, whether the enemy is defined as insurgents ... or repressive dictators. Even though such interventions sometimes emphasise the protection of civilians or the need to find a political settlement ... In other words, peace comes before human rights in classic peace-keeping and victory comes before human rights in classic military interventions' (Barcelona Report, 2003: I I).

More concretely, ideas related to the military that have emerged out of the thinking about human security involve two key issues. The first is that while there is a continuing need for military forces, they must be configured and used in new ways so as to be capable of being integrated with 'civilian capabilities, such as police, tax and customs officials, judges, administrators, providers of aid and human rights specialists. The ultimate aim is to be able to deploy different packages of military-civilian capabilities according to the situation' (Barcelona Report, 2003: 2I). The second is a particular emphasis 'on communication, consultation, dialogue and partnership with the local population in order to improve early warning, intelligence gathering, mobilisation of local support, implementation and sustainability' (Barcelona Report, 2003: 6). Both issues centre on the links between the military and civilians: on how the military works with NGOs and how it learns to aggregate the demands of the civilian population into the decision-making process.

Yet in this regard, as Donna Winslow (2002: 39; Winslow, 2003; Archer, 2003) suggests, civilian NGOs and the military are at odds with each other over a variety of issues: their basic goals (alleviate human suffering versus preparation for war), approaches to violence (non-violence versus controlled use of violence), links to national identity (internationalist versus strongly nationalistic) and decisionmaking styles (decentralised versus hierarchical). Indeed, some civilian organisations are very wary of using military assets in carrying 
out their operations because military assets can be used for peacekeeping or peace enforcement at the same time that they are being used for humanitarian assistance. Hence, even though organisations such as the International Red Cross understand only too well the value of armed protection of its equipment and personnel, they are guarded in using military assets for their operations (Winslow, 2002: 40 ). Indeed, in some of the pronouncements in the Bologna Report there is recognition of these points:
'There are considerable obstacles to overcome. Among civilians, the military are often associated with a mission of violence, which is considered to conflict with and in- deed may hamper the purposes of civilian officers, in par- ticular aid-providers ... Among the military, there is a ten- dency to assume that civilians "get in the way" and are less efficient at carrying out specified tasks or that the mil- itary's job is war-fighting, not nation-building or protect- ing humanitarian aid workers. Both sides need to adapt' (Barcelona Report, 2003: 2 I, emphasis added).

This chapter focuses on this process of adaptation between military and civilian organisations in and around humanitarian missions.

\section{Human Rights and the IDF}

In order to contextualise the two cases, I begin with the declared policy of the IDF in regard to the present Intifada which has lasted for more than seven years. Many senior commanders have rather consistently stated that the formal aims of checkpoints include minimising damage to the lives and livelihood of the Palestinian population, the need to distinguish between innocents and armed aggressors, and the necessity for a smooth and efficient 'handling' of the people moving through them. This kind of emphasis should be seen in an historical context: with the eruption of the Al-Aqsa Intifada (the Palestinian uprising in September 2000), the IDF began to change its public rhetoric and to create a humanitarian discourse centred on its actions in the occupied territories.

This move should be seen as part of a global change in the ways in which military action is interpreted in many industrial societies. One 
of the most significant developments concerning contemporary armed forces has been their growing transparency to external agents such as political leaders, the media, the judiciary, pressure groups, or international non-state institutions such as the International Red Cross, Human Rights Watch and Amnesty International. As a succession of scholars have noted, this transparency is closely related to worldwide trends towards the valuing of human rights and new public attitudes towards the perpetration of violence (Burk, I998; Dandeker, I998: 34; Finnemore, I999). As Finnemore (I999: I49-50) explains, the social rules and cultural models that govern the way in which states and soldiers fight have become increasingly globalised and transnationalised. While such rules and models governing military behaviour originate outside a particular military organisation or country, the new kinds of organisations that have no governmental standing can nevertheless dictate and shape the rules of war (Finnemore, I999: I63).

The IDF has not been disconnected from these developments. While many rules governing the use of force existed during the first Palestinian Intifada (I987-I992), the IDF appears to have internalised many of the dictates and prescriptions found in this global discourse on human rights and reacted in concrete organisational measures to put them into effect. Two examples of this development are the promulgation of a military 'code of ethics' as part of new weight given to 'human rights' in operational deployments and the development of a new attitude to the International Red Cross.

In the mid-I990s the IDF formally adopted the code of ethics after years of deliberation by internal committees aided by external experts (Kasher, 1996). It was promulgated formally in 1994 and disseminated throughout the armed forces through seminars, documents and various deliberations. The emphasis on human rights or, as it is known in the army, the 'dignity of man' (kvod ha'adam) is employed in regard to such things as sexual harassment or the rights of soldiers during basic training (Israel Democracy Institute, 200I). No less important, it is officially seen as placing constraints on attitudes towards enemies, decision making during violent conflicts, rules of engagement, illegal orders and plunder. What is significant about this discourse is that it is part of the ongoing debates through which the IDF is attempting to define itself and the actions it undertakes in ways akin to similar developments in other armed forces (Dandeker, I998: 35-6; Smith, 2000). 
Next, take the changed attitude of the Israeli military to the Red Cross, which was perceived for many years as an 'extension' of the UN and just another international body critical of Israel's policy. Since 2003 , however, its representatives have been invited to give presentations within the IDF: for example, in the checkpoints commanders' course two employees of the organisation present a compulsory lecture. Another lecture is regularly given at the inter-service staff college by the regional Red Cross representative based in Cairo (Schiff, 2004). The new relations between the IDF and the Red Cross began as part of the recognition on the part of the IDF that wars have changed their character and that many of them now take place in the heart of civilian populations (Schiff, 2004).

Concrete changes in regard to the Palestinians began to emerge in 2002, about a year or two into the Al-Aqsa Intifada. It began when some Israeli political and military leaders realised that, while there was a need to use force to handle the conflict, it had to be done in a way that differentiates between the wider civilian population and armed aggressors. This policy meant an all-out war against terror networks and armed groups combined with letting the majority of the population not involved in such activities to live their normal, routine life. The idea was that the humanitarian treatment of the general Palestinian population would lead to a change in public attitudes and that this change would contribute to the termination of violent activities. Examining the way this rhetoric has been implemented by the IDF, however, one finds that it actually adopted a very narrow definition of human rights: one that narrows the rights of the Palestinians to only very basic needs, such as essential livelihood or medical care in extreme cases of need.

What is more, the human rights discourse and humanitarian rhetoric were often adopted as external ideas that the IDF had to comply with for a variety of reasons such as public relations, the pressure of the media and social movements, international norms, and public debates within Israel. Concretely, these discourses are often understood by local level commanders as 'just' another operational parameter such as terrain, the weather or forces to be deployed - which is to be taken into account when running their units and that could be, under certain circumstances, ignored. Quite a lot of evidence of these kinds of developments was found in interviews I carried out with colleagues (Ben-Ari et al., 2005). One reserve commander with much experience in the territories told us that the rules and regulations 
found in permanent checkpoints explicitly include a stress on maintaining, as far as possible, the life of the innocent civilians. In reality, of course, this kind of emphasis continued to stand in a state of tension with security considerations. As another commander told us:

\begin{abstract}
'Sometimes we are "over-large"' and you see it in the cases where you find a boy with an explosives belt inside an ambulance and in other cases. But despite these cases we continue to provide a humane passage [through the checkpoints] because it's important.'
\end{abstract}

Against this background, we now turn to two types of organisations or organisational mechanisms that are most clearly recognised as dealing with humanitarian issues.

\title{
'Humanitarian Officers'
}

One of the initiators of this project told us that it began because of the terrible disorder and conditions that characterised the checkpoints during the first two years of the current Intifada. The IDF agreed to the project which began in March 2002 when three or four reserve officers (later they included NCOS) volunteered for ten to fourteen days of service to perform as sort of 'arbitrators' in regard to who can move through the checkpoints and who cannot. In this capacity, they are charged with handling all of the 'problematic' cases of Palestinians, and their work consists of hearing out each case, examining the assortment of documents and permits Palestinians possess, carefully weighing the merits of the case and then deciding whether to permit the move through. The requirements for deployment as humanitarian officers include previous service in the Israeli military, being over 22 years old, and the ability to speak Hebrew and English (Arabic is optional). Once accepted to the programme, volunteers go through a few days of weapons training and learn special cross-cultural interpersonal skills designed to take on young IDF soldiers and Palestinians coming from a wide variety of ages and occupations (Leyden, 2005 a; Leyden, $2005 \mathrm{~b}$ ). As one interviewee from a project on the checkpoints explained (Ben-Ari et al., 2005): 
'The whole rationale of the project is to bring older more mature people who receive a much more thorough preparation before moving into the checkpoint. They are usually deployed in groups of three or four volunteers. And the trainers, they commit themselves to coming to the checkpoint once in ten days and to give a long briefing of about three or four hours. [In addition] they always coach the new team for a full day so that they internalise the problematic aspects of this job. They [the trainers] are impressive people who have already contributed tens of days to this project.'

As the commander of the programme told the Jerusalem Post (Leyden, 2005a):

'We can't allow a young I 8-year-old soldier who has no understanding and experience of family and business obligations to set policy at these check posts ... How can an $\mathrm{i} 8$ or I9-year-old soldier access medical, financial and family problems? They can't. How can they identify with a mother carrying a baby for an hour or an unemployed man with few twisted teeth and ripped clothes seeking employment?'

A major problem encountered at the checkpoints involves the application of a myriad of rules, classifications and conditions to the cases of Palestinians moving through them. In fact, the army categorises the Palestinian population into no less than four general classes and over forty sub-categories, each of which necessitates different regulations regarding movement through checkpoints. To give a few examples of the variety of cases soldiers must handle, one can find Palestinians with blue, green and orange ID cards, residents of the territories with foreign passports, people with VIP status and documents, special instances of permits from the army to move through different checkpoints, residents of different areas defined in the Oslo accords (A, B and C), residents of Jerusalem, employees of the Jerusalem municipality, employees of international organisations, people dealing with business and commerce with their own authorisations, pupils and students, tourists, and journalists (local and international). Each one of these categories, or their mix, is governed by different regulations and thus allows various kinds of passage be- 
tween differentially defined areas. In reality, when soldiers suspect someone who has arrived at a checkpoint and want more information about him or her, they use the communications net to contact the territorial brigade who is then linked to the General Security Service (Shabak) or the police. It is the latter two organisations that make the final decision about who is allowed or not to pass the checkpoint. This procedure may take hours since it involves a number of administrative levels, avenues of communication, and organisations.

It is not surprising to learn that one implication of this situation is the depersonalisation of Palestinians. Instead of an individual, detailed encounter, the interaction is between categories and roles. It is distanced and alienated and therefore depersonalised (Ben-Ari et al., 2005). The process is intensified by the informal categorisations that both sides use. The soldiers and Palestinians do not perceive each other simplistically as undifferentiated collectivities but rather through rough distinctions such as the 'pregnant woman', the 'good soldier'. It is for this reason that the IDF has allowed the humanitarian officers to be deployed at the checkpoints. Take the following excerpts (from Ben-Ari et al., 2005). One platoon commander from the Passages Company at Kalandia checkpoint:

'[T]here are three volunteers that are deployed here at the point where the pedestrians go through.... and there you find most of the humanitarian problems. They [the volunteers, who all are reservists] are given the task of handling them because of their age and their life experience. That is the idea.'

The manner by which such reservists talk about their experiences at the checkpoints underscores the above observations:

'I felt a bit like I was babysitting the younger soldiers. Even the commander of the conscripts told us this straightforwardly: that they expect us reservists to worry that things will not get out of control, that there will be no violence and that there will be no "humanitarian cases". By this they mean that they will not find themselves in the news with a Palestinian that has been beaten or a woman that has given birth at the checkpoint.' 
Another reservist told a journalist that:

'Reservists are people with families and when they see a woman and a baby they understand what it means. On the other hand, a conscript is someone who has no breadth of thinking. I wish that they worked like the reservists. It's because of their lack of maturity and not badness.' (Tsomet Hasharon, I I June 2004).

In fact, one Palestinian in his mid-thirties told us: 'With the pedestrians it sometimes helps. Why? They are older reservists there that have an ability to use their discretion.' Thus, it may well be that the volunteers are especially suited, as one perceptive individual told us, to show 'the human side of the army'. Their very status, as older individuals who are both civilians and soldiers, allows them a more flexible treatment of various Palestinian cases brought before them. While overstated a bit, the commander of the scheme told the Jerusalem Post:

'Our volunteers ... assist our young soldiers with security and provide an understanding, helping hand to the Palestinians. Their job is to make life easier for those who cross the borders. To assist women who are holding babies and children, aid the elderly and sick and provide an open ear to Palestinian professionals who have special problems' (Leyden, 2005a).

Interestingly, humanitarian officers carrying out similar roles can be found in other places. Thus for example, in the Congo the UN has deployed humanitarian officers under difficult and precarious security conditions to provide temporary shelter and protection to civilians threatened by armed conflicts, conduct assessments in regard to the need for assistance, negotiate access to vulnerable people by putting pressure on the belligerents, facilitate the transportation of $\mathrm{NGO}$ and UN agency staff undertaking critical humanitarian missions, and encourage the placement of military observers in areas with extreme humanitarian needs (UNMDRC, 2005).

In addition, soon after the conflict ended in former Yugoslavia, Greece, the Russian Federation and Switzerland launched a humanitarian initiative by the name of FOCUs. This humanitarian relief op- 
eration was aimed at assisting all victims of the crisis by setting up warehouse facilities in the region and distributing supplies throughout the territory according to the people's needs, regardless of ethnic and religious affiliation (Ziogas, 2005). Finally, in the recent Iraqi conflict, while Britain's humanitarian officers did not follow the U K military into Iraq during the conflict, they did have the capacity to undertake emergency relief and 'small impact' projects such as supplying fuel or power supplies or repairing sanitation facilities and other small-scale infrastructure. Their aim was not undertaking long-term reconstruction programmes but providing funding to other organisations capable of delivering long-term assistance (Loescher and Helton, 2003).

The prime problem with such humanitarian deployments, however, is the potential for the militarisation of the missions. One such danger is that some military members may feel that participating in peace operations dulls their 'warriors' edge'. Indeed, many soldiers and officers do not believe in their role as 'global street workers', and consider peace operations to be inappropriate for combat soldiers (Winslow, 2002: 39-40). This is certainly the case for some Israeli soldiers: underlying the attitudes and behaviour of many (if not most) soldiers towards Palestinians is a very basic military position that is based on envisioning worst-case scenarios. In other words, the IDF (like any military) is an institution that is based on preparation for the gravest eventualities of attack or aggression. Concretely, the two scenarios the checkpoints are linked to include the 'slippage' of armed Palestinians through these points and the waging of terror attacks within Israel, and the possibility of assaults on the checkpoints themselves. The implication of this situation is a very fundamental view of all Palestinians as potential enemies who may attack Israelis within the Green Line or the military personnel manning the passages.

One expression of this militarisation is the constant effort commanders and soldiers make to maintain strict control of the checkpoints. Soldiers constantly make efforts to create a 'zone of security' between themselves and the Palestinians they inspect. This 'zone' involves a line beyond which the latter are not allowed to venture unless they are called forward by the soldiers. Often, however, because Palestinians keep pressing forward, soldiers make them go back to the waiting line by stopping the whole process of inspection until order is restored. 
In addition, most commanders are preoccupied by what is called 'force protection', with the safety of soldiers under their command. Among other things, force protection involves the use of large reinforced concrete blocks (with soldiers behind them), watchtowers, machine guns and rifles and the taking of higher grounds around the checkpoints to prevent potential attacks. Militarisation is further reinforced by the structure of appraisals and incentives used concerning units and commanders. It appears that the IDF measures the success of units and commanders deployed at checkpoints in strict security terms: whether the unit has prevented the movement of armed aggressors through them and not whether it has succeeded in efficiently and smoothly handling the vast majority of civilian innocents. Indeed, proponents of human security seem to be very aware of these potentials:

'At the operational level, the primary task of any deployment is to assist law enforcement ... For the military this means a shift from the traditional use of military force as war-fighting to that of law enforcement. The military have to be actively involved in assisting the police and civil authorities ... In human security operations, the lives of those deployed [force protection] cannot be privileged. The aim should be to protect people and minimise all casualties. This is more akin to the traditional approach of the police, who risk their lives to save others, even though they are prepared to kill in extremis, as human security forces should be' (Barcelona Report, 2003: 19-20).

Yet as we have seen, the reserve status of the humanitarian officers, as well as their age and overall maturity, tends to offset some of the dangers of militarisation.

\section{MachsomWatch}

During the first two years of the Al-Aqsa Intifada, a host of representatives of human rights movements monitored and interceded at the checkpoints. Among these movements are the International Solidarity Movement, the Ecumenical Accompaniment Programme in Palestine and Israel coordinated by the World Council of Churches (Hop- 
per, 2004) and B'Tselem, an Israeli human rights movement. Yet the most active movement at the checkpoints has undoubtedly been MachsomWatch. This movement was established during the first year of the conflict (2000) in response to repeated reports in the press about human rights abuses of Palestinians crossing checkpoints. Volunteers from this exclusively women's movement attend checkpoints in small groups of two to four members, observe what is going on, document their observations and report - in texts and pictures - to external bodies such as media representatives and their website (Maymon and Ben-Ari, n.d.). As Ginzburg (2003: 6) observes, the women of the movement are 'another pair of eyes in this space ... They try to influence the gaze of the soldiers at the checkpoints. They raise questions related to human rights, and in this way they hope to challenge the binary view of friend-enemy and to prevent in their interventions and presence the reduction to a strictly political gaze.'

Often Machsom Watch volunteers actively intervene in the dynamics of the checkpoints. Thus, for example, at times inquiries from MachsomWatch volunteers lead to the opening of an additional inspection position to those already functioning. Other times, they enter the 'negotiations' between the members of the security forces and Palestinians. During one instance, my colleagues and I witnessed two volunteers intercede in a discussion held between three Palestinian taxi drivers and a policewoman at A-Ram checkpoint (in North Jerusalem). The police officer had taken the keys of the three taxis and was giving them traffic tickets. The volunteers interrupted and tried to phone one of the IDF hotlines. Although it turned out that the hotline could not help in cases of traffic violations, the volunteer nevertheless joined the Palestinian men in their interchange with the police officer. In all, as one volunteer told us, the story of MachsomWatch includes a significant, if limited, measure of success:

'We saw that in the field things were very unclear. The instructions to the soldiers were unclear; that is, we couldn't understand how the soldiers operate and why they let someone pass and why they don't, and what they are allowed and what they are not allowed and then we started writing letters of complaint ... We simply looked for the commanders to make things clear. And then there was an opportunity when they invited us and said "Let's talk and see how we can work together.” And the first brigade 
commander in charge of the Kalandia checkpoint ... he invited the people from the civil administration [the military branch in charge of civil affairs], the company and battalion commanders [who were deployed there] and wanted us to tell them what our problems were and that they would tell us what they expected of us.'

This initial cooperation and willingness to listen on the part of the military led to further meetings and through that some personal links were established between activists and certain aides and spokespersons of the commanders. What was important was that a direct and independent line of communication was opened to the brigade level and became part of the movement's 'tool box'. What seems to have happened is that the army and the movement have struck a sort of unwritten contract. Especially at the level of field commanders this situation implied a willingness to improve things. One activist told us:

'I called the army to report that the soldiers were shooting at children and they told me that they were not shooting at children. I said to him they are shooting now and they told me that I don't understand. I called the humanitarian hotlines of the army and through them to the commanders. In the evening we talked to the brigade commander and told him, after my friend who is a doctor in Ramalla said that a boy arrived there who was brain dead after having been shot with live ammunition [as opposed to rubber-coated steel bullets]. He [the commander] told me that there was no use of live fire there and he said that he had carried out an investigation ... I said that you cannot have the full picture if you talk only to the soldiers ... The next morning he phoned and said that it was terrible what had happened. And from then on when I phone they answer me immediately.'

Ginzburg (2003: 5) provides another example from what a volunteer told her:

'Within a few minutes about ten soldiers advanced towards the children and started shooting at them. Shocked about what we are seeing - armed soldiers, with helmets 
and flak jackets, shooting at a small group of school children - we immediately phoned the assistant to the brigade commander of Binyamin who told us that the order is to shoot rubber bullets into the air. I told him that I am seeing with my very eyes that the shooting is not in the air but is aimed at the children and that, as is well known, rubber bullets can kill.'

Along these lines, among the reasons why the movement is relatively successful and accepted by many senior commanders is that its members offer means to circumvent the normal military bureaucratic lines: they can and do directly phone territorial brigade commanders or the representatives of the civil administration. In addition, they may circumvent the lines through journalists covering military affairs. They very often know the local commanders and how to approach them. No less important, they provide senior commanders with a kind of feedback mechanism in terms of what is going on and how different units are functioning. The military thus has a certain interest in their work.

The success of the movement is limited, however, because the very presence of the volunteers sometimes contributes to the tensions between soldiers and the Palestinians. As one Palestinian interviewee explained:

'It fires up the soldiers and let them delay the people on purpose. And they [the volunteers] sometimes understood this and distanced themselves [from the interactions between the soldiers and Palestinians]. They [the volunteers] went over to where the taxis are and only wrote down [their reports].'

Thus soldiers tend to see MachsomWatchers either as a hindrance, another obstacle in carrying out their role, or as a mechanism for calming a highly emotional and aggressive situation. In this latter sense, members of the movement act as mediators, as third parties that seek to observe and sometimes intervene in what is going on.

To conclude this section, from the perspective of the movement, it may diminish the irregularities and ameliorate some of the negative implications of the checkpoints. But the emphasis on amelioration or improvement of the existing situation stand in contrast to the stated 
aim of the movement which is to act against the very existence of the checkpoints and to work towards their removal. Thus, as another volunteer reminded us:

'With the officers we can agree about many things but there is a very clear wall between us ... In principle we oppose the checkpoints and the army is the one that manages them.'

In effect, the movement has transformed from one oriented primarily to human rights violations and an anti-occupation policy into a humanitarian one. Indeed, human rights groups often have to choose between long and short-term change: between changing the political apparatus, that is damaging human rights, and proffering concrete help to its victims. MachsomWatch decided - whether intentionally or inadvertently - to place the greatest emphasis in its work at the local level and to stress humanitarian issues. The day-to-day influence of the movement has been felt most strongly in this regard. Yet this situation, in turn, leads to a paradoxical outcome. One could certainly argue that because MachsomWatch is successful in regard to humanitarian issues it contributes to the prolongation of the occupation and the existence of the checkpoints. As one insightful volunteer told us, success at the local level makes the 'machine' of the occupation work more smoothly (Maymon and Ben-Ari, n.d.).

\section{'In-Between Organisations'-A Conclusion}

How can we explain the existence and role of the humanitarian officers and MachsomWatch volunteers? To answer this question involves a somewhat abstract framework (Ben-Ari, Maymon, Gazit and Shatzberg, 2005). Facing uncertainty, organisations create structures of attention, interpretation and decision making which exert a crucial influence on their ability to control their external environments and internal operations in times of crises. In terms of our case, in order to counter the uncertainty and ambiguity of the checkpoints, the Israeli military uses two sets of mechanisms. The first set focuses on easing any decision making that is to be made by routinising the procedures and transactions that go on as much as possible. As Morgan (1986: 82) reminds us, in the face of uncertainty, 'poli- 
cies, programmes, plans, rules and standard operating procedures ... help to simplify organisational reality'. Ideally, like a machine that can be activated at any moment when needed, the IDF has an organisational system - complete with a predetermined division of labour, fixed procedures, and categorisations of Palestinians - that is put into operation at the checkpoints. In less abstract terms, this mechanism refers to the administrative means for 'processing' Palestinians at the checkpoints.

The problem is that bureaucratic directives simply cannot cover all of the possible contingencies that emerge in the concrete situations of the checkpoints. Many soldiers and officers often have difficulties in applying the procedures and classifications defined by the army. Organisationally speaking, the greater the uncertainty and ambiguity 'the more difficult it is to programme and routinise activity by preplanning a response' (Morgan, I986: 82). The IDF needs to somehow apply the general principles it has developed into the diversity of actual situations it encounters because there are always issues that are left open for negotiation and that evolve out of the 'peculiarities' of each case. Processing and procedures may be routinised, but the handling of civilians always involves a potential for breach, for unexpected disruptions. It is here that the second set of mechanisms that militaries use - that allow wide scope for discretion and judgement, and reliance placed on feedback rather than on programming as a means of control - comes into effect.

In response, the army has either developed or allied itself with different kinds of hybrid organisations: the humanitarian officers who as reservists are both civilians and army personnel, and members of MachsomWatch who can act as mediators between the parties. The strength of these hybrids lies in their ability to perceive the needs and views of the Palestinians and to 'translate' them into concrete suggestions that the military can take into account at the checkpoints. To be sure, we are not arguing that these organisations are unqualified success stories but rather that their unique characteristics make them better able to help the IDF deal with contingencies and uncertainties. Thus, because it is often difficult to conduct full-scale 'consultations' with a population that is in a situation of severe insecurity these 'inbetween' mechanisms do offer some kind of conduit for the voices of some Palestinians.

Yet it is crucial to understand the work of such organisations from the perspective of the military and its logic-of-action, because it 
bears upon the whole idea of human security operations. From this perspective, the problem is one of control at the checkpoints. What the two cases show is how the Israeli military does not leave uncontrolled areas but rather develops a hybrid kind of control that is half civilian and half military. It develops this control within a sort of 'buffer zone' within the checkpoints. I term this a buffer zone, because while the military is, of course, present, it has developed or adopted unique representatives or coalition partners in a way that buffers this presence. Through the construction of such a 'buffer zone' and the management of what goes on within it, the army concurrently displays its 'human', caring aspects, reacts to some of the Palestinians' demands, maintains over-all control of the situation, prevents potential disruptions, and demonstrates its efficiency in accomplishing the 'mission' of deployment at the checkpoints. In effect, I would argue, following Winslow (2002, 2003) and Miller ( 1997 ), that which emerges is a situational consensus:

'[O]rganisations that share a common goal and depend on each other to reach that goal can develop a cooperative relationship and yet retain distinct organisational memberships and cultures. In short, you don't have to be best friends in order to be able to work well together.' (Winslow, 2002: 5I).

The IDF, like any other contemporary military, is influenced by its social environment in the ways it uses violence. During the previous two decades or so, we have been witness to the emergence of what may be called a global discourse on human rights and the rules and expectations developed within it for the 'proper' use of force, within which Israeli is not an isolated case (Bar and Ben-Ari, 2005). What the cases of the humanitarian officers and MachsomWatch show is that their actions are part of the new relations between the IDF and various social movements centred primarily on humanitarian issues and to a very limited extent on human rights.

Do the activities of such organisations meet the goals of human security policies? In '... much of the Middle East today, physical security demands priority. The challenge of psychological security is often neglected. Dehumanisation, disempowerment, and humiliation play a central role in sustaining conflict and breeding terror' (Amman Roundtable, 2004: 3). I am far from denying the need to end Israel's 
occupation of the Palestinians and of the occupation as the primary obstacle to any kind of accord between the two peoples. But perhaps in their own limited way, these two organisations do help in some small way to ease the everyday burdens of people who move through the checkpoints. Again to be clear, I do not suggest that IDF soldiers are all becoming representatives of Amnesty International or delegates of various humanitarian organisations or that they all internalise the assumptions and expectations of the new global human rights discourse. Far from it. Rather, I suggest that, like other military establishments, the IDF is more open than in the past to interactions with and the influence of this global discourse as it is expressed in concrete organisations 'on the ground'.

\section{References}

Amman Roundtable (2004), The Amman Roundtable: Human Security in the Middle East, Amman: Meeting Co-Hosted by HRH Prince El Hassan bin Talal and Oxford Research Group.

Archer, Sarah E. (2003), "Civilian and Military Cooperation in Complex Humanitarian Operations”, Military Review (March-April), pp. 32-4I.

Bar, Net and Eyal Ben-Ari (2005), "Israeli Snipers in the Al-Aqsa Intifada: Killing, Humanity and Lived Experience”, Third World Quarterly, Vol. 26, No. I, pp. 133-52.

(Barcelona Report) Study Group on Europe's Security Capabilities (2003), A Human Security Doctrine for Europe: Report of the Barcelona Study Group on Europe's Security Capabilities, Barcelona, September I 5, 2003, available online: http://www.lse.ac.uk/Depts/global/Publications/HumanSecurityDoctrine.pdf; also published in: Glasius, Marlies and Mary Kaldor, Eds. (2006), A Human Security Doctrine for Europe: Project, Principles, Practicalities, London: Routledge, pp. 327-356.

Ben-Ari, Eyal, Meirav Maymon, Nir Gazit and Ron Shatzberg (2005), From Checkpoints to Flowpoints: Sites of Friction between the Israel Defence Forces and the Palestinians, Department of Sociology and Anthropology, The Hebrew University of Jerusalem.

Burk, James (1998), “Introduction, I998: Ten Years after the New Times”, in: Burk, James, Ed., The Adaptive Military, New Brunswick, N.J.: Transaction, pp. I-24.

Cohen, Stanley ( I988), “Criminology and the Uprising”, Tikkun, Vol. 3 , No. 5, pp. 60-62, 95-96. 
Dandeker, Christopher (I998), "Nationalism, Nation-States, and Violence at the End of the Twentieth Century: A Sociological View", in: Dandeker, Christopher, Ed., Nationalism and Violence, New Brunswick, N.J.: Transaction, pp. $2 \mathrm{I}-47$.

Finnemore, Martha (I999), "Rules of War and Wars of Rules: The International Red Cross and the Restraint of State Violence", in: Boli, John and George M. Thomas, Eds., Constructing World Culture: International Non-governmental Organizations Since I 875, Stanford: Stanford University Press, pp. I4965 .

Ginzburg, Ruti (2003), "Returning the Gaze to the 'Darkened Subject'”, Paper presented at the Annual Meeting of the Israel Anthropological Association.

Hopper, Maurice (2004), "Working with the Barrier - The Separation of Jayyous", Palestine-Israel Journal, Vol. I I, No. I, pp. 87-89.

Israel Democracy Institute (200I), "Dignity of Man in the Israel Defense Forces", The Army-Society Project of the IDF and the Israel Democracy Institute, Jerusalem: Israel Democracy Institute.

Kasher, Asa (1996), Military Ethics, Tel-Aviv: Ministry of Defence Publication House.

Leyden, Joel (2005a), “IDF Expands Humanitarian Officers Program”, Jerusalem Post Online Edition, http://www.israelnewsagency.com/idfhumanitarianisrael Io07.html.

Leyden, Joel (2005b), “Israel Sends IDF Humanitarian Officers to Front Lines”, Israel News Agency, http://www.israelnewsagency.com/israelidfhumanitarianIo048.html.

Loescher, Gil and Arthur C. Helton (2003), "Rebuilding Iraq: London sees it differently from Washington”, OpenDemocracy.com, March 26, www.cfr. org/pub5762/arthur_c_helton_gil_loescher/rebuilding_iraq_london sees_it_ differently_from_washington.php.

Maymon, Meirav and Eyal Ben-Ari (n.d.), "MachsomWatch: Women, Watching, and Their Effects on Israeli Checkpoints in the West Bank".

Miller, Laura (I997), "Relief Workers’ Attitudes Towards the U.S. Military in Peacekeeping Operations”, Paper presented at the Biennial Inter-University Seminar on Armed Forces and Society Conference, Baltimore.

Morgan, Gareth (I986), Images of Organization, Beverly Hills: Sage.

Schiff, Zev (2004), "I 5 Dec Evidence of Change: The Attitude to the Red Cross", Haaretz, page B-I.

Smith, Hugh (2000), “The Last Casualty? Public Perceptions of Bearable Cost in a Democracy”, in: Evans, Michael and Alan Ryan, Eds., The Human Face of Warfare: Killing, Fear and Chaos in Battle, London: Allen and Unwin, pp. $54-83$. 
UNMDRC (2005), “Humanitarian Affairs Section. United Nations Mission in the Democratic Republic of Congo", http://www.monuc.org/HAS/.

Winslow, Donna (2002), "Strange Bedfellows: NG Os and the Military in $\mathrm{Hu}$ manitarian Crisis”, International Journal of Peace Studies, Vol. 7, No. 2, pp. 35-55.

Winslow, Donna (2003), Human Security, Amsterdam: The Free University. www.machsomwatch.org.

Ziogas, Nikos (2005), "Greek Humanitarian Contribution to the Kosovo Crisis", Journal of Foreign Policy Issues, http://www.hri.org/MFA/thesis/spring99/humanitarian.html. 


\title{
8 Human Security from Below: \\ Freedom from Fear and Lifeline Operations
}

\author{
Mient Jan Faber
}

The central question of this chapter is whether it is possible to develop a consistent human security policy to tackle and survive contemporary wars. After the Cold War, it is said that we now really live in a global world and no longer in a world determined only by national and international relations (Shaw, I999: 6I-80). This global world order is mostly conceived as a governance system in which states and non-state actors are taking part and sharing responsibility. States are repositioning themselves within wider governance networks of nonstate actors (NGOs) and international institutions (UN, IMF, World Bank, World Court, G-8, etc.) guided by cosmopolitan law (Castells, I996). In the global world, there are by definition only internal conflicts/wars. Hence conflicts should be addressed by law enforcement instruments. Still, the military, whether or not authorised by the UN Security Council, have to play a central role in terminating wars. Since many of the present wars are total in character, which among other things means that the Geneva Conventions regarding noncombatants are violated, the issue of human security has become paramount.

Most contemporary wars take place in post-colonial countries in Africa, post-communist countries in Europe, (semi-)occupied countries and weak states in the Middle East. Although many of these wars are localised, a myriad of transnational connections are involved, including political, economic, military and cultural links. There is a global presence in these wars: international reporters, mercenary troops, military advisers, private military companies, terrorist networks, irregular forces, black market racketeering, criminal gangs, diaspora volunteers, humanitarian agencies, human rights 
groups, peace groups, peacekeepers, international organisations (Un, EU, NATO, African Union, OSCE). They all make use of mobile phones, e-mail, internet, satellite connections, credit cards, dollars, and so on. Indeed, a diverse global community is connected with contemporary local wars. Its involvement has a profound impact on human security, both negatively and positively.

In these wars, called 'post-modern wars' (Gray, I997), 'network wars' (Duffield, 2002), 'new wars' (Kaldor, I999) or 'degenerate wars' (Shaw, I 999), we face a blurring of the distinctions between war (defined as violence between organised groups for political motives), organised crime for private purposes, and large-scale violations of human rights by states or other politically organised groups. In each case, civilians are explicitly targeted and have become the main victims.

Consequently, in the global world the debate on security shows a shift in paradigms. State security, the long-time centrepiece of the debate, now has a serious competitor in human security. In previous centuries the focus of security (state) was on territory. Boundaries were considered 'borders of violence' with the enemy (threat) located on the other side. In the global world, human security has become central and is now obviously focused on the individual, that is, on people's right to security. The global community, in whatever composition, is today, more than ever before, aware of the fact that it has to act in situations where the security of its people is seriously threatened.

In this chapter, I will introduce a new concept relating to initiatives of citizens, living under conditions of war, to serve their own security and/or the security of other citizens: 'human security from below'. A human security policy from below refers to initiatives from society (civil) aimed at the security of fellow citizens in conflict areas.

\section{Freedom from Fear}

There are two competing schools of human security. The first one is mainly focused on 'freedom from want' which is about human needs in economic, health, food, social and environmental terms. The UN report Human Security Now (Ogata, Sen et al., 2003) also includes fair trade, access to health care, patent rights, access to education and basic freedoms. The second school is more tightly focused and 
sticks to 'freedom from fear', which is about removing the use or threat of force and violence from people's everyday lives. Its agenda lists issues like anti-personnel mines, child soldiers, impunity, small arms proliferation and so on (Krause, 2004). Most policy documents refer to human security as an issue dealing with 'freedom from want', although it is recognised that the security of a human being is determined by two major factors: 'freedom from want' and 'freedom from fear'.

A recent example is provided by the un report (2004), A More Secure World: Our Shared Responsibility. It lists six clusters of quite different threats: interstate wars, intrastate wars, poverty/disease/ environmental degradation, weapons of mass destruction (wMDs), terrorism, and crime. Combating poverty is considered a main approach to tackle most, if not all, of these threats. In other words, the therapy for this huge variety of problems has to be found in the area of 'freedom from want'. Although the report refers to the responsibility to protect civilians from large-scale human rights violations, it emphasises that this responsibility is held, first and foremost, by national governments. 'When a state fails to protect its civilians, the international community then has a further responsibility to act, through humanitarian operations, monitoring missions and diplomatic pressure - and with force if necessary, though only as a last resort' (UN report, 2004, p. 7). It remains unclear, however, how any of these measures can directly contribute to human security. Indeed, even the use of military force is not a security guarantee for individual people, as most war situations teach us. So, it is still an open question how to assure 'freedom from fear' in the most life-threatening circumstances.

One of the rare documents that really tries to address the 'fear' side of the human security problem is the advisory report to the EU, $A \mathrm{Hu}$ man Security Doctrine for Europe (Barcelona Report, 2003). In that report one finds a list of principles for a human security doctrine, like the primacy of human rights and a bottom-up approach. The bottom-up approach is an attempt to explicitly involve people living in conflict areas in the human security policies of the $\mathrm{EU}$. The report makes a sharp distinction between a war (with or without the adjective 'humanitarian') and a human security operation. The latter is seen as a cosmopolitan law enforcement operation, making use of a police force, in special cases equipped with military means.

The report focuses on the terminology developed by Kaldor ( I 999, 
200I). She objects to the use of classic 'war' terminology in cases that do not refer to a violent battle between two or more collectives (states, regional alliances, non-state entities). Kaldor argues that one should not talk of a 'war on terror', a 'war on poverty', or a 'war on drugs'. Moreover, wars in the traditional sense hardly exist nowadays. Recent conflicts in Africa, the Middle East, the Balkans and the Caucasus do not belong to the category of classic wars. She suggests labelling these 'new wars', where 'new' points at the very different quality of the present war phenomenon, although in a way it is still a 'war'. Indeed, the main actors should not be equated to criminal gangs, since they are networks with a political agenda; they claim state power. So, classic war and new war should be distinguished from each other.

Inspired by Kaldor, Martin Shaw (I999) prefers to speak of 'degenerate wars', underlining, on the one hand, that human beings are the main targets and, on the other hand, the continuity with the total wars of the twentieth century and their genocidal aspects. For Shaw (I999: I 5), Nazism is 'the closest model for the new warfare in the old canon'. The definition of the Jews as an enemy appeared irrational by the standards of conventional interstate war. By the standards of contemporary warfare, however, defining non-state entities as the enemy is almost a rational model, if only in the sense that it is a goal pursued methodically.

Chris H. Gray (1997) observes continuity between modern and post-modern wars. According to him, post-modern war is modern war in its full completion. His book is a warning against the denial of the essence of war feeding on dead and maimed bodies. Some postmodernists claim that war today is a mere spectacle and simulation. Gray observes that there is an infatuation with new superficial theories of pseudo-war, such as cyber war, in the face of the apocalyptic dangers of real war. 'War has us in its grip, and we have it' (Gray, I997: I0).

Without directly referring to her, Duffield (2002) follows Kaldor's distinction between old and new wars. He develops a theory of 'new war' as a complex network enterprise. Although the most common response to the new wars is to interpret them as a failure of modernity, by examining the new security terrain in terms of its morphological characteristics, it is possible to come to another conclusion. Duffield claims that wars in places like Colombia, Afghanistan, Yugoslavia and the Democratic Republic of the Congo can be under- 
stood as a realisation of the intrinsic potential of transnational terrorist/criminal networks, offering this asset to failed state representatives. The Afghan crisis is but one example. Duffield (2002: I 57): 'Not only did Western intelligence underestimate the danger posed by the Al Qaeda network, but in the initial phase of the Afghanistan campaign it was widely believed that - as a failed state - even the threat of military action would cause the Taliban to disintegrate.'

In the next section, I will address the question of whether a humanitarian intervention is a human security operation as well. The Barcelona Report does not pay attention to this question. Indeed, it gives a doctrine, but not a policy. What I am looking for is a humanitarian policy in which military means, alongside other instruments, are used in such a way that the protection of people is central during the whole operation. Protection should be defined as an active and focused human security policy, which is different from just trying to avoid collateral damage.

\section{Human Security and Humanitarian Intervention}

One might assume that a humanitarian intervention (implying war) and a human security operation are intrinsically connected. In theory, this could be the case. In practice, this is hardly ever realised. There are several examples to show this. One of the first and, broadly considered, successful international humanitarian interventions happened in northern Iraq. It was carried out in I99I by a coalition of the willing. Despite the fact that it was conceived as a denial operation, that is, to deny the Iraqi air force access to the airspace over northern Iraq, it was labelled 'humanitarian', probably for the simple reason that it seemed to comply with the usual definition of a humanitarian intervention. The Advisory Council on International Affairs of the Dutch government (AIV, 2000: 6) defines humanitarian intervention as: 'The threat or use of force by one or more states, whether or not in the context of an international organisation, on the territory of another state: (a) in order to end existing or prevent imminent grave, large-scale violations of fundamental human rights, particularly individuals' right to life, irrespective of their nationality; (b) without the prior authorisation of the Security Council and without the consent of legitimate government of the state on whose territory the intervention takes place.' 
In the aftermath of the first Gulf War (I990-I99I), the then-president of the us, George Herbert W. Bush, called upon the Kurds in the north and the Shiites in the south of Iraq to engage in a popular uprising against the Iraqi regime (Galbraith, 2006). This led to the liberation of all of Kurdistan, including Kirkuk. It also provoked heavy retaliation by the Iraqi army, which led to a mass exodus of Kurds to Iran and Iraq. UN Security Council Resolution 688 (adopted on 5 April I99I) was used by the U s, the U K and France to start patrolling the skies over northern Iraq. The resolution 'insists that Iraq allow immediate access by international humanitarian organisations to all those in need of assistance in all parts of Iraq and make available all necessary facilities for their operations'. The enforcement of a no-fly zone was considered necessary for implementation of the resolution. This, combined with the capabilities of the Kurdish army (called peshmergas) to hold its positions in most of the Kurdish territories north of Kirkuk, created a de facto, autonomous Kurdistan, later on called an internationally (UN) recognised safe haven inside Iraq. Human security was indirectly but positively affected by the enforcement of the no-fly zone, and directly guaranteed by the peshmergas on the ground. In retrospect, the no-fly enforcement operation-assuch (!) has however been considered a successful humanitarian intervention (Leezenberg, 2000).

The Kosovo war (I999), waged by NATO, is another example of what is considered to be a successful humanitarian intervention (Kurth, 2002). In this case, human security issues were not addressed by any military force. On the contrary, human security deteriorated sharply during and immediately after the NATO intervention. The Serbian leader Milošević retaliated against the NATO bombing campaign with a massive ethnic cleansing offensive, with the obvious intention of removing all Albanians from Kosovo. NATO dispatched no ground forces to protect the Kosovar Albanians, not even near the borders with FYROM and Albania, where people were massed in huge numbers under desperate circumstances (Human Rights Watch, 1999). After 78 days of bombings, Milošević conceded to sign an agreement on the future of Kosovo. The day after the signing, NATO ground forces entered Kosovo. They did not intervene when returning Albanians took revenge on the Serb population, driving them from their homes and looting and burning their properties. There was hardly any protection for the Serbs (Human Rights Watch, I999). Nevertheless, and in retrospect, the NAто (air) campaign was labelled a successful humanitarian intervention (Shea, I999). 
The original aim of the NATO operation was an attempt to force Milošević to sign a treaty on the future of Kosovo (De Wijk, 2000). In the eyes of public opinion (Shea, I999), it became a humanitarian intervention due to the asymmetric reaction (ethnic cleansing) of the Serb authorities in Belgrade. It could have become a human security operation as well if special measures had been taken to protect civilians on the ground. A human security operation is focused on the protection of human beings and is quite different from an operation which only tries to limit collateral damage as far as human casualties are concerned. However, the 'collateral damage' argument has been often used to justify the military operation as 'humanitarian', as was done by NATO's spokesperson Jamie Shea during his speech in London (Shea, 1999). Shea defended the NATO campaign on the grounds that it had respected the criteria of the Just War doctrine, and therefore he labelled it 'humanitarian'. Still, 'humanitarian' is not the same as human security. NATO's intervention did not offer any protection to Albanian or Serb civilians. NATO troops behaved like bystanders, watching from the air as hundreds of thousands of Albanians were dumped over the borders and watching from the ground as tens of thousands of Serbs were forced to flee from the region. The Albanians returned; most of the Serbs never did.

These examples show that humanitarian intervention and human security are not by definition part of one and the same operation. On the contrary! A successful humanitarian intervention might, however, create the necessary conditions for a human security operation. Then again, there is no automatic sequence of events. After a humanitarian intervention, whether or not explicitly done for that reason, a long (Iraq, 2003) or short (Kosovo, 1999) period may follow where human security is not at all guaranteed.

\section{Human Security from Below}

Human security is mostly discussed as an initiative from above. The Responsibility to Protect, an imperative adopted by the UN General Assembly ( 5 September 2005, Draft Outcome Document, Articles I 38 -I 40, I 43, A/60/L.I), refers to the obligation of any state to provide security to its citizens. However, a state at war, a failed state, an oppressive state or a rogue state is often unable, respectively unwilling, to accept a responsibility to protect. On the contrary, people 
have to fear for their lives because of the state in which they live. Since international bodies, like the UN or a coalition of the willing, are often not prepared or capable of filling the human security gap in a particular region, people themselves are the main agents to provide at least some protection for themselves and others around. To put it another way: they are simply forced to initiate their own protection.

It is against the background of growing insecurity that ordinary people (have to) take initiatives to protect themselves. Growing insecurity and human security initiatives from below go hand in hand. In other words, self-protection goes hand in hand with the creation of security communities and security zones. (Extended) families, tribes, religious communities, neighbourhoods, refugee communities, ethnic communities and so on, transform themselves into security identities providing shelter to people under physical threat. The foreboding of an upcoming war is often very tangible. In the early spring of I 99 I, still well before the collapse of the Federal Republic of Yugoslavia, Serb workers in Croatia had to sign a declaration of loyalty to the Republic of Croatia in order to keep their jobs. Holiday houses near the Croatian coast, owned by Serbs, were confiscated. Many other measures were also taken which made it clear that war was around the corner and that in Croatia the Serbs were outcasts (Faber and Kaldor, I99I). Facing this situation, only a few choices were left for the Serbs. So, they started to move away to Serbia or decided to protect themselves in their own communities in Serb-dominated areas inside Croatia. Indeed, faced with a (civil) war, many people will start to move to places where their own (ethnic) group has a stronghold, while others will try to leave the country. Refugees and internally displaced persons (IDPs) form the hard core of the most widespread phenomenon of self-protection in a country during war. It destroys the normal social fabric and puts the country under enormous stress.

Propaganda is a well-known method, used in times of war to incite the population. But it also serves to calm down the refugee/IDP community. In Azerbaijan, close to one million people were forcefully removed, between 1988 and 1994, from a large buffer zone around Mt. Karabakh which was unilaterally declared independent by Armenian segregates. Since then, tens of thousand of IDPs live under dreadful circumstances in camps throughout the country. For many years, until he died in 2003, late President Haidar Aliyev in his almost-daily appearance on television addressed the nation and, in particular the IDPs, to assure them to remain patient and trustful (Faber, 
2002). They were urged to believe that he was the only one who was able to guarantee their security as well as a safe return, one day, to their places of origin. His propaganda worked and kept the ID Ps relatively quiet. Ilham Aliyev, the son and successor of Haidar, is using the same instruments (television) vis-à-vis the huge community of displaced people.

Hate-inciting propaganda often prolongs war. Civic activists are aware of this and have discovered the power of mass media to counter official propaganda. There are many examples of media interventions, all over the world, used by civic activists in conflict areas (Howard, 2003). During the Bosnian war, shopkeepers in Sarajevo hung posters on their windows demanding the establishment of a UN protectorate in the city. Despite oppressive Serb rule, a popular independent Albanian newspaper, Koha Ditore, was published in Kosovo and widely read. Everywhere clandestine radio stations became a rather effective antidote against the warmongers and the poisoned atmosphere (Howard, 2003).

Summing up, in a war situation, the social fabric of a society is completely warped and fundamentally different from normal circumstances. Two of the most significant differences are:

I In post-modern/network/new/degenerate wars, which are characterised as wars against civilians, society is confronted with a huge number of refugees and internally displaced people (ID PS). During the war in Bosnia Herzegovina (I992-I995), about fifty per cent of the total population of two million people were on the run and/or ethnically cleansed (UNHCR, I 994);

2 The public space is poisoned with psychological warfare demonising all members of a different nation, ethnicity or religion. But a main purpose of the instigators of psychological warfare is also to 'unite-in-fear' its own people, in other words: to create a feeling of human security as long as one stays within one's group.

In war situations human security from below is paramount on three levels: 


\section{Self-protection}

There are numerous initiatives people will take when their security is threatened. When your city is bombed or your neighbourhood shelled, you will blind your windows, keep the children at home and hoard food. Self-organisations emerge for a variety of reasons: emergency schools for the children, neighbourhood protection by vigilance units, emergency care, communication with the outside world and so on. In Baghdad, not only are whole neighbourhoods cleansed on the basis of religion and ethnicity, but the inhabitants have organised their own security systems including armed guards who patrol the area and prevent official national police units from entering since nobody trusts them (Faber, 2006). In Bosnia, thousands of Muslims threatened by either Serbs or Croats, or by both, fleed to a number of enclaves in Serb- or Croat-controlled areas where they tried to protect and defend themselves, calling upon the world to save them from extermination. In order to survive, they were in desperate need of human security protection from elsewhere, in particular from the free world - that is, from abroad. That brings us to the second level of human security from below.

\section{Horizontal protection}

In war situations, it is very important for people to be connected to lifelines. Human security is the sum of freedom from want and freedom from fear. As far as freedom from want is concerned, all kinds of humanitarian organisations will try to connect with people in war situations and provide food and medicines. To address freedom from fear is, however, more complicated. Obviously, for people in war situations, it is essential to be in touch with the free world in order to sustain hope that one day the war will be over. Today, there is a growing number of lifelines to address freedom of fear problems. E-mail networks are constructed through which information is shared and solidarity campaigns are developed.

Civic activists from abroad travel to conflict areas in order to discuss plans for providing human security or to operate as couriers on behalf of people inside a conflict region. In the I980s, during the Cold War, in Europe an East-West network of dissidents (in the East) and human rights and peace activists (in the West) came into existence. Its main policy was to launch media interventions in order to face the free world with East European dissidents who, even under arrest, had the courage to publicly express the need for freedom in 
Eastern Europe (E-W Network, I986). A frequently used lifeline is free radio stations broadcasting news and solidarity programmes for ID Ps and other people in war situations. Of course, lifelines can serve a military purpose (smuggling weapons) too.

In conflict areas, special prisons for state enemies are often notorious (cf. Abu Ghraib in Baghdad). Not everybody is willing to go underground or able to escape the country in time. Community leaders, accused of separatism, can count on life sentences, if not worse. Lifeline operations may have a vital meaning here. In Azerbaijan, I was asked by family members of Aliakram Gumbatov, a leader of the regional Tallish community, to pay visits to a special prison for political delinquents in Qobustan, 6o kilometres north of Baku, in the middle of nowhere. The objective was to restore communication with the imprisoned husband and leader and help to get him released. The operation succeeded. Lifeline operations have always taken place and occur in each and every war situation. They have become a new focusing point for peace and human rights activists: citizens protecting citizens (Van Tongeren, 2005).

To summarise, horizontal protection is offered by a wide variety of non-state actors. Armenian diaspora communities providing weapons and manpower to homeland people in Nagorno-Karabakh, children from the Netherlands writing letters to children in Sarajevo: these are both examples of horizontal protection.

\section{Vertical protection}

If security cannot be provided by the obvious state institutions (army, police, judiciary), people in danger will try to establish surrogate security institutions themselves. In 2006, arms were collected and distributed in Christian-populated villages in Iraq, armed guards and vigilance committees were set up, and checkpoints erected (Faber, 2006). However, sometimes foreign powers may come to the rescue. UN safe areas for the protection of IDPs were established in Bosnia during the (I992-I995) war. A NATO intervention was carried out in Kosovo, followed by a Un protectorate over the region. A Un Transitional Authority ruled Cambodia from March 1992 till September I 993. Operating under a UN mandate, NATO forces back up provincial reconstruction teams (PRTs) in Afghanistan. Its main goal is to project security and assist reconstruction, a typical human security operation from above. American and British forces fulfil similar roles in Iraq. In many conflict areas, civil-military cooperation (CIMIC) has become a booming industry. ${ }^{\mathrm{I}}$ 
During the wars in Yugoslavia (I99I-I995), the UNHCR has shown a great interest in providing civic activists with identity cards enabling them to board UN planes and travel with UN vehicles through war zones. Based on their reputation, some civic networks received the status of UNHCR implementing agencies, although they operated fully independently. The UNHCR was well aware of the fact that these groups were often dealing with the political concerns of IDPs and refugees. One example of this was the Helsinki Citizens' Assembly (hCa), an international civic network with local branches in Bosnia. The 'Safe Haven' campaign of the hCa, launched in I992, contributed to the establishment of six Safe Areas in 1993, in the middle of the war in Bosnia Herzegovina. The basic ideas behind this campaign were developed in Sarajevo, in the autumn of I992, during discussions between UNHCR officials and hCa activists (Helsinki Citizens’ Assembly, Mission Reports \& Magazines, Paris/Baku).

\section{Sub-conclusion}

I) Of course, it depends on the characteristics of the (degenerate) war what kind of human security initiatives (from below) emerge and are (im)possible. In the 2006 July-August war between the state of Israel and the state-within-a-state of Lebanon/Hezbollah, it was almost impossible for the Lebanese people in the southern areas controlled by Hezbollah to arrange some kind of self-protection, apart from fleeing. The military wing of Hezbollah had deployed most of its operating bases inside local communities. Missiles and launchers were put inside ordinary houses; fighters deliberately stayed in the communities. By doing so, Hezbollah tried to hide the distinction between combatants and non-combatants. In other words, the fighting strategy of Hezbollah did not take into account the human security needs of its own people. By doing so, it confronted Israel with a hard dilemma: either not to attack Hezbollah from the air or to run the risk of creating a humanitarian catastrophe which would easily mobilise world public opinion against Israel. That is indeed what happened. Israel was blamed for its indiscriminate bombing campaign. On the other hand, Israeli people were provided with human security measures, shelters in particular, by their own authorities, against the missile attacks from Hezbollah.

2) Self-protection as a form of human security from below can have far-reaching political consequences. In Kosovo, the region north of the Ibar River has been protected by the local Serbs themselves since 
NATO's intervention in I999. It has created a de facto partition of the province. The same is happening in Iraq, where Kurdistan is already semi-independent while in the rest of Iraq a degenerate war is waged, in particular between Shiites and Sunnis, in which each side is protecting its 'own' areas, often on the initiative of local people, up to neighbourhoods in Baghdad and other mixed cities. If the overall national security structures (police, army, judiciary) remain weak, and consequently a weak state emerges, then sooner or later the country might fall apart, at least partly due to the human security initiatives from below. Armed human security initiatives from below tend to create peoples' armies and thus a strong incentive towards self-determination.

3) Potentially, the most far-reaching and politically effective human security initiatives from below are those in which the three layers (self-protection, horizontal protection, vertical protection) interconnect. In that case layer one, the security of the community, is linked up with layer two, the international lifelines, as well as with layer three, support from national and international state institutions (international governmental organisations, IGOs). In the next section, I will give a detailed description of a human security initiative from below where the first layer of self-protection directly faced the third layer of vertical protection, with dramatic consequences: the case of Srebrenica.

\section{Human Security Inaction and In Action}

During the war in Bosnia Herzegovina (I992-I995), the UN established six safe areas in the country to protect the local population, many of them refugees. The first safe area was established in Srebrenica, in April I993. UnSC Resolution 8I9 demanded Yugoslavia (Serbia and Montenegro) to immediately 'take all measures ... to prevent the commission of the crime of genocide'. Moreover, the UnSC 'demand[s] that all parties concerned treat Srebrenica and its surroundings as a safe area which should be free from any armed attacks ... Troops from the United Nations Protection Force (UNPROFOR) were stationed in the safe areas under a mandate which included the delivery of protection to the people - a good example of a human security operation. This policy, however, failed, for not only in Srebrenica - where genocide took place, and the male Muslim popula- 
tion was killed - but also in the other safe areas, the lives of the people were never secured. Shortly after the genocide in Srebrenica, at the end of August 1995, NATO started a bombing campaign which helped to bring the Serbs to their knees. However, unlike in Kosovo, this air campaign was neither conceived nor (in retrospect) considered a humanitarian intervention. For obvious reasons: when the horse is stolen, the stable door is locked.

When the Bosnian-Serbs overran the enclave Srebrenica, about 25,000-30,000 people, among them 2,000 Muslim men and boys, tried to find shelter at the Dutch compound in Potocari, a few kilometres north of the city. Dutchbat allowed only a limited number (4,000-5,000), including some 300-500 Muslim men, into the compound. The others were moved to some empty factory halls and vehicles near the bus station in the vicinity of the compound. Many of them had to stay in the open air. During the night, a small number (I00-I30) of Dutch soldiers were positioned outside the compound, manning improvised observation posts in a cordon around the area where the refugees were gathered. The Dutch command did not set up a security system in order to protect the refugees against Serb intruders, who were chasing Muslim men and boys, particularly at night. Despite the cordon, not a single intruder was stopped. The number of Muslim men and boys murdered on $\mathrm{I} 2-\mathrm{I} 33 \mathrm{July}$, in the vicinity of the compound is estimated between IOO and 400 (NIOD, 2002: 2774).

In the early morning of I 2 July, the Serb military commander, General Mladić, started to marshal transportation assets, taking the deportation of the IDPs into his own hands while not allowing Dutchbat to monitor, let alone supervise, the operation (Butler, 2000: 2526). Early attempts of Dutchbat to put some of its own soldiers on the buses or to escort the buses with some of its own vehicles were blocked. Dutch soldiers were threatened and sometimes robbed; guns, cars, uniforms, helmets and other equipment were confiscated or simply stolen. Facing the Serb behaviour, the Dutch command decided to keep a low-profile, non-provocative posture towards the Serbs. Unarmed and no longer wearing flak jackets or helmets outside the compound, Dutchbat restricted itself to humanitarian aid and facilitated the deportation, among other things through the establishment of a blocking point where the refugees were divided into small groups of about 60 people before being told to move forward to the buses, where Serb soldiers separated the Muslim men and boys from the small groups, forcing them to assemble under the pretext of inter- 
rogation in the so-called 'white house' (NIOD, 2002, 26I6-26I9).

Dutchbat command had concluded that the Serbs were masters of the scene outside the compound and that the Dutch should avoid any confrontation. Maltreatment of the refugees, the Muslim men and boys in particular, was ignored. Reports from Dutch officers and the coordinator of Medicine Sans Frontier (MSF) about summary executions, the destruction of identity papers of the Muslim men and boys, the shocking situation inside 'the white house' and other wrongdoings didn't provoke any protest from the Dutchbat command. A human security policy was totally absent (NIOD, 2002, 2653-2657).

Within the compound, the Dutch remained fully in charge. When refugees outside the compound were all deported, however, Dutchbat itself commanded the refugees inside the compound to leave, one family after another. To avoid any violent confrontation between the Muslims and the Serbs, Dutchbat ordered the refugees to empty their pockets before leaving the compound. At the gate, the refugees were handed over to the Serbs (Nuhanović, 2002).

From a human security perspective, the Dutch behaviour should be described as human security inaction. None of the relevant principles for a human security operation, as formulated in the Barcelona report, in particular the primacy of human rights and a bottom-up approach, were observed.

Obviously, human security matters most to the people directly involved. They will take initiatives to provide some security for themselves, their family members and others, in a situation where they are confronted with physical threats. In other words, a human security operation from below will be undertaken. How did this unfold in the UN safe area Srebrenica?

One of the survivors of the genocide, Hasan Nuhanović, has written a detailed chronology of the events in the enclave. ${ }^{2}$ In particular, he describes what happened between Io-I 3 July when the Serb army approached Srebrenica and the local population had to seek refuge. Most of the Muslim men and boys (I0,000-I 5, ,00) decided to form a long column and make an effort to break through the Serb defences in order to reach Muslim-controlled territory. A few thousand Muslim men and boys stayed behind with their families. In the afternoon of I I July, all of them, about 25,000-30,000 people, left their homes seeking refuge from the Serbs in the Dutch compound in Potocari. There they faced a serious setback in their initial human security ef- 
forts, because Dutchbat only allowed a relatively small group of people $(4, \infty 00-5, \infty 00)$ into the compound. The others were ordered to find shelter in some buildings outside the compound. This was the first failed human security initiative from below.

Serb commander Mladić wanted to meet with some representatives of the local population of the enclave. He ordered Dutchbat Commander Karremans to bring him these people. Karremans managed to form a refugee committee of three people: Nesib Mandzić, a teacher; Ibro Nuhanović, a businessman (and the father of Hasan); and Camila Omanović, an economist. On the morning of I 2 July, the committee was present at a meeting in Bratunac, ten kilometres north of Srebrenica, where Mladić declared that he himself would supervise the evacuation of the refugees. He added that the able-bodied Muslim men were first to be screened for war crimes. When the delegation returned at the compound, Dutchbat Deputy Commander Franken asked the refugee committee to develop an evacuation plan; he handed out notebooks and pencils. The representatives were deeply alarmed concerning the fate of the Muslim men and boys now it was clear that Mladić wanted to separate them from the others. Together, they discussed the option of an evacuation under supervision of the UN and the ICRC. But nothing was put on paper, since Mladić showed up in the area outside the compound and moreover tens of (Serb) buses and other vehicles arrived. Events took a different turn and the second human security initiative of the refugees themselves failed.

A third human security initiative from below was an urgent request to Franken to stop the deportation. In fact, a chaotic situation had emerged outside the compound. Since the refugees were extremely frightened with the Serbs around, many of them ran to the buses in order to leave the enclave as soon as possible. The representatives, however, feared for the lives of the Muslim men and boys and asked Franken to intervene. He refused. Obviously, the situation was no longer under his control. Moreover, he himself wanted the evacuation to go ahead, for humanitarian reasons, no matter the risks the Muslim men and boys were running.

A fourth human security initiative from below was suggested by Franken himself. With the actions of Amnesty International for the release of political prisoners in mind, he came up with the idea to compose a list of all Muslim men and boys, including their names and birthdates. If their coordinates were known to the UN, the Serbs would hopefully be more reluctant to harm them. With some hesita- 
tions, the representatives accepted the idea and although tens of men refused to be listed, 252 names were collected from men who were in the compound. Franken signed the list and faxed it to Zagreb and The Hague, where it got lost. This initiative also failed.

Finally, a fifth human security initiative from below was undertaken by Hasan and his father Ibro Nuhanović. Hasan had brought his parents and his younger brother into Camp Potocari, the UN compound, and tried to save his brother's life by putting his name on a list of Dutchbat personnel. Dutchbat personnel were supposed to be evacuated together with the battalion. It was again Franken who blocked the initiative. When the family was ordered to leave the compound and was on its way to the gate, Franken addressed father Ibro Nuhanović. He told him that he could stay behind because he was a representative of the refugees. (On I6 June 2005, at a preliminary hearing before a court in The Hague, Dutchbat commander Karremans declared that the representatives of the refugees were supposed to stay within the compound and not be deported with the other refugees; he needed them for communication with the Serbs.) When Nuhanović turned around and pointed at his youngest son, Franken said: no. In a split second the father had to make a choice. Either stay alive with his oldest son or die with his youngest son. He chose to die.

The events in Srebrenica suggest that, in a tangled up, isolated situation where different parties have their own agendas, human security can only be realised(partly or wholly) if at least some of the agendas overlap. Despite the presence of a UN compound in Potocari, the Dutch battalion did not share the security concerns of the refugees. Its own concern was to solve the dreadful situation in and around the compound as soon as possible. For that reason it did not confront the Serbs. On the contrary, it facilitated the deportation as well as the separation of Muslim men and boys. Thus, the goal of the Serbs (ethnic cleansing and genocide) and the goal of Dutchbat (a swift and continuous evacuation of the refugees) ran parallel, at the expense of the human security needs of the Muslim population (Faber, 2005a).

\section{Human Security and Peace Activism}

Peace groups from inside and outside a conflict region, who by definition are interested in conflict resolution, have shown increased inter- 
est in the three layers of human security activities from below (Van Tongeren, 2005). By doing so, they face some internal contradictions and controversies which will be discussed now.

One would imagine that peace activists are deeply involved in human security from below activities. This is not yet the case. Peace activism on the level of civil society still has to come to terms with the paradigm shift from state security to human security. Modern Western peace activism came into existence after the Napoleonic wars, in the beginning of the nineteenth century. Since then its primary goal has been to abolish interstate war. Today, the main tools of action are still peace education, peace congresses, political lobbying and mass mobilisation. Peace advocacy often includes the mobilisation of ordinary people at the grassroots level for putting pressure on governments and parliaments not to solve conflicts by the use of force. In the end, its declared goal of abandoning war as an instrument for solving conflicts between states should be realised through international law, the establishment of the International Court of Justice, and the creation of an international authority entrusted with a monopoly on the use of offensive violence between states (the League of Nations and later the United Nations). Interestingly, during this whole period only a minority of the peace activists was committed to the principle of pacifism, or non-violence in general. The majority considered itself pragmatic pacifists or pacificists, being against interstate war with the exception of self-defence (Ceadel, 1989).

When countries prepare for war or in cases where war is (on the brink of) breaking out, peace movements often manage to mobilise huge numbers of people on the streets, particularly against their own governments. During the I980s, peace movements initiated massive rallies against the ongoing nuclear arms race between East and West, while in 2002-2003, even larger numbers of people filled the streets of many capitals around the world protesting a possible Us-UK military intervention in Iraq (Cortright, 2004). Since the I990s, the new focus on human security is embraced by a small liberal wing of the peace movement. It is engaged in an often virulent debate with the more traditional majority of socialist left-wing-oriented peace activists. In Cushman (2005), A Matter of Principle: Humanitarian Arguments for War in Iraq, liberal left-wing writers and activists, including Paul Berman, Adam Michnik, Ian Buruma, Jose RamosHorta and the present author defended their 'dissident', pro-interventionist views, in the debate on the eve of the war in Iraq. More in 
particular, the human security adherents raised the question: what should be done if your partners in a conflict area, with and for whom you work on human security issues, are in favour of a war that they see as a unique opportunity for liberation and, consequently, a step towards human security?

For many years, activists from Kosovo, in particular members of the international Helsinki Citizens' Assembly (hCa), have put a lot of effort into trying to convince the international community to take note of the ongoing oppression of the Kosovar Albanians under the regime of Slobodan Milošević. A solution could be found, they (hCa) argued, by bringing Kosovo under international supervision. When all peaceful attempts in that direction failed and NATO launched a military air campaign against the Serb regime in I999, the hCa activists were in support of NATO because freedom from fear was finally within reach. The Western peace movement at large vehemently opposed NATO's intervention. In the middle of the Kosovo war, in May I999, a millennium peace conference, organised by the Hague Appeal for Peace, was attended by 10,000 peace activists from all over the world. Political celebrities, including un Secretary-General Kofi Annan, were also present in The Hague. At one moment, a young Kosovar Albanian, an hCa activist, who was expelled from his country during the ethnic cleansing campaign conducted by the Serb forces, addressed the conference at my request and expressed his gratitude towards NATO. He received a loudly hostile reaction from the audience. His voice was not welcome for it undermined the main aim of the conference: to stop NATO's intervention against Yugoslavia and to solve this interstate conflict peacefully.

Even more so, the US-UK intervention in Iraq (2003) was a clearcut case for the international peace movement. Never before in modern history, had so many people occupied the streets in protest. Activists in Iraq, many of them from the north (Kurdistan) where Saddam's control was marginal, were shocked watching the footage on TV. They reacted in public statements and open letters complaining that the rallies played into the hands of a cruel dictator. ${ }^{3}$ But the voices from Iraq had hardly any impact on the peace marchers; partly due to the fact that the lines of communication between civic activists from the West and Iraq were underdeveloped. However, sporadic heated debates and even some splits within peace groups in the West took place (Faber, 2005b). Given the chaotic and violent situation that has gradually emerged after the removal of Saddam Hussein, 
representatives of the liberal wing of the peace movement, this author included, publicly acknowledged that human security in Iraq has not improved so far, despite the numerous human security initiatives from below that have taken place in the country.

One might wonder if in our global world, where interstate wars are overtaken by post-modern/new/degenerate/network wars, a new kind of peace activism will emerge, quite different from the traditional interstate one. Will the global world, characterised by a hybrid composition of state and non-state actors, lead peace activists into a reappraisal of their main aims, in the context of an emerging global civil society? It is not at all obvious.

\section{The Global War on Terrorism and Civil Society}

A main locus and focus of the Global War on Terrorism is the Middle East, Iraq in particular. This is not the place to discuss the rationale behind the US-UK intervention in Iraq. But it is not the first time in history that the us has tried to change the political environment of a whole region. It did so in the nineteenth century in Latin America, based on the Monroe doctrine and the Manifest Destiny doctrine (Poetker, 1967; De Wilde, 2003), twice in Europe (after World War I and World War II), and once again, in Japan. The results were mixed, to say the least. Indeed, the concept of national self-determination, advocated as a peace panacea by the American President Woodrow Wilson in his famous Fourteen Points Speech (I9 I 8), did not prevent another world war. On the contrary; although the new political configuration of the European continent in I9 8 was the outcome of World War I and not the result of Wilson's call for self-determination, the very concept itself was widely used by irredentist movements in Central-Eastern Europe in their striving for (re)unification with the motherland. Or, conversely, the official policy of Nazi Germany was to unite all Germans in one country. Some have argued (e.g. Gray, 2003: I03) that the political instrumentalisation of Wilson's 'interventionist' idea of self-determination made the next catastrophe (WWII) unavoidable.

President George W. Bush is shaking up the Middle East as part of his strategy to defeat terrorism (Council of Foreign Relations, 2006). On 6 November 2003 , in an address to the National Endowment for Democracy, the us President announced a 'forward strategy of free- 
dom' to promote democracy throughout the Middle East. 'As long as freedom and democracy do not flourish in the Middle East, it will remain stagnant, resentful and violent - and serve as an exporter of violence and terror to free nations' (Bush, 2003). Although most civic activists are opposed to the strategies of the American government, especially those carried out in Iraq, there is nevertheless a broad understanding that the spread of democracy is the right answer to the threat of terrorism. Fighting for democracy is considered an indirect approach to enhance human security.

The so-called Madrid Summit, organised in March 2005 by the Club de Madrid (2005), a group of former heads of states and government, produced a series of substantive volumes on democracy and terrorism culminating in the Madrid Agenda for Action. Like President Bush has done before, the Madrid Report of the Working Group on Civil Society, Democracy and Terrorism states that civil society and democracy represent alternatives to terrorism. Indirectly criticising Bush, the report emphasises, however, that democracy cannot be imposed from above or from outside. Yet, most political violence in the present world is connected with authoritarian or failed states (Mack and Nielsen, 2005). How then will democracy and legitimate authority be established in those places? The question remains unanswered in the Madrid Report.

I have noticed a tendency among peace activists who marched against the US-UK intervention in Iraq and/or the NATO intervention in Yugoslavia (Kosovo) to equate, in legal terms, (American-led) military interventions, unauthorised by the UNSC, with violent (Islamic) jihad operations, in particular suicide-terrorist attacks. Both are considered to be illegal operations in our global world where only the UNSC has a monopoly on the international use of violent means for offensive purposes. Since most terrorist attacks do take place in countries/regions where outside powers have a clear (political, military, economic, cultural) interest, peace activists usually focus their campaigns on the intervening power. The argument is that an end to foreign occupation/presence will also stop most of the terrorist activities. This argument is supported by Random House, the world's largest database of information about suicide terrorists, based in Chicago. Its head of office, Robert Pape (2005), has found that suicide-terrorist attacks are not driven primarily by religion, but rather by foreign occupation. The religious factor becomes relatively stronger when there is a difference in religion between the occupier 
and the occupied community, Pape argued in an interview in The American Conservative (2005). This sounds reasonable when applied to the Palestinian territories where the overwhelming majority of the people is against Israeli occupation. But also in Iraq where liberation was welcomed by a majority, while at the same time, American occupation is rejected by a majority. However, in 2006, the legitimately elected authority is still in favour of an American presence (for the time being). ${ }^{4}$ Indeed, the withdrawal of the American troops, without a guarantee that the legitimate authority will be able to cope with the insurgency and 'defeat' terrorism, is considered counterproductive by the present regime.

The Club de Madrid (2005: introduction) notes that 'terrorism is an attack on democracy and human rights'. It says that 'only freedom and democracy can ultimately defeat terrorism'. Consequently, 'a vibrant civil society plays a strategic role in protecting local communities, countering extremist ideologies and dealing with political violence'. However, a vibrant civil society presupposes a highly developed democracy. But, even in such countries, terrorist groups can arise. Many Europeans will remember the I970s and I980s when Europe was confronted with the Red Brigades in Italy and the Red Army Faction (RAF) in West Germany. ${ }^{5}$ It took dozens of casualties and several decades to defeat the terrorists. I, therefore, agree with Gregory Gause (2005:4) that democracy alone cannot defeat terrorism. In my view, it is even doubtful if anybody or anything can.

Countering extremist ideologies is also not an easy task for civic activists for the simple reason that any fruitful encounter requires both parties to at least respect the rules of the game. In democracies, terrorist groups will do everything to hide their intentions and often isolate themselves from the rest of society. Of course, it is possible to address a wider audience with possibly open admirers or silent sympathisers of terrorist groups. Since so many contemporary terrorists identify themselves as religious Muslims, more in particular as Islamic fundamentalists, one can address the Muslim communities at large, in one's own neighbourhood. This indirect approach has indeed become an important activity in Western societies in tackling the terrorist problem.

In societies where terrorist movements do have a popular base, like Hamas or to a lesser extent Islamic Jihad in the Palestinian territories, it is very hard and often dangerous for (local) civic activists to confront these groups directly, in an attempt to counter extreme 
ideologies. My own experience in countries like Palestine and Iraq is that civic activists try to avoid a direct confrontation with terrorist groups, though they are not afraid to condemn suicide attacks. Here, lifeline operations might be helpful. In situations where terrorist groups do have civic wings operating in public, it is sometimes easier and less risky for civic activists from abroad to approach representatives of such groups. I have done so in Palestine, after consultations with local partners. Since violence, as such, and terrorist attacks, in particular, raise many ethical questions, I have confronted leaders from Hamas and Islamic Jihad on that level. It was both astonishing and interesting to learn from those encounters that the area of personal ethics was a tabula rasa for my counterparts, and, moreover, that the death of innocent Israelis gives at least some meaning to the real death of a suicide bomber (martyr) and the virtual death of the community around him. His eternal life will be guaranteed after the attack, whereas their temporary life hardly had any significance at all. Indeed, in Gaza life is impossible (Faber, 2005c).

Where terrorist groups, like Hezbollah in Lebanon, receive open or covert support from a large community in a conflict area, their actions might become an integral part of a wider range of (violent) behaviour well known in post-modern/network/new/degenerate warfare. Hezbollah terrorists are now considered freedom fighters par excellence. They are exclusive (in their fighting methods) and inclusive (that is community based) at the same time and, therefore, approachable, also for civic activists. Interestingly enough, this double role can make the terrorist - or freedom fighter - part of the solution, not just part of the problem. When sooner or later, the conflict is settled or dies out, they have to find their place in a peaceful society, perhaps even (temporarily) in prison.

Visiting Gaza, in May 2005, the spokesperson of Hamas told me that his movement considered itself a political power holder alongside the Palestinian Authority (PA), but not a political party in opposition. In other words, after the withdrawal of the Jewish settlements from Gaza, in the summer of 2005 , Hamas was prepared to take control over (parts of) Gaza. It sounded to me like a recipe for or a preannouncement of a civil war in Gaza. In January 2006, Hamas won the elections for the legislative council and soon thereafter constituted a new government. Since it was unwilling to recognise the state of Israel and to engage into negotiations, the Palestinian territories were run in 2006 by two competing authorities: the Palestinian Authority 
headed by President Mahmoud Abbas and the Palestinian government of Hamas. After a short marriage between Hamas and Fatah in a national unity government, Hamas took full control over Gaza, whereupon Mahmoud Abbas sacked the unity government and outlawed Hamas as a terrorist organisation. In the summer of 2007 , a two-state solution emerged within the Palestinian territories.

The Israeli war with Lebanon and more explicitly with Hezbollah, in the summer of 2006 , was paralleled by a war with Gaza, more explicitly against Hamas. As always, human security was the first victim of the war. In my view, the deployment of two international human security response forces (one in Gaza and the other one in southern Lebanon) modelled after the ideas outlined in the Barcelona Report (2003), and with the mandate to prevent the outbreak of a civil war, could have been a useful instrument to stabilise the situation. Unfortunately, traditional international missions still prevail. Moreover, the experience in Iraq has made the international community rather hesitant towards new adventures.

\section{Conclusions}

The central question of this chapter was whether it is possible to develop a consistent human security policy to tackle degenerate wars: a policy in which military and other means are used in such a way that the protection of people is the central objective during the whole operation. I have shown that such a policy from above does not exist, today. However, considering the wide variety of local and transnational initiatives in a degenerate war situation, human security policies from below do exist. They do have an enormous impact on the situation on the ground, although this does not necessarily mean that they are signs of an emerging just peace. On the contrary, the socalled security communities and security zones that do emerge during a conflict as a result of human security initiatives from below may contribute to a fragmentation of the country in which they occur. To prevent sustained conflicts and new wars, they have to be matched with human security policies from above. Unfortunately, despite all the rhetoric about human security, a consistent policy still lies beyond the horizon.

After the genocides in Rwanda (I994) and Srebrenica (I995), the international community has become more aware of the necessity 
and duty to protect individual human beings in contemporary conflict areas. Human security, as a deliberate policy, has become part of the international agenda. Today, several un missions are based on a mandate in which the protection of people is explicitly mentioned. Nevertheless, those missions are not based on a human security doctrine as suggested in the Barcelona Report, but instead they have become more robust in a military sense. To give an example: according to the mandate and the rules of engagement of the latest UN mission in the DRC, UN soldiers are allowed to kill people, including children, who are threatening civilians. ${ }^{6}$ This is not what we normally understand by (cosmopolitan) law enforcement; on the contrary, it comes suspiciously close to the laws of warfare. On a much larger scale this is happening in Iraq as well. The American army is at war in Iraq and since it is rather difficult to identify the enemy (insurgents and terrorists), each civilian is afraid of becoming a target. Such an approach is obviously unable to win the hearts and minds of ordinary people. In other words, it is not a human security operation.

I have argued that humanitarian intervention can be a precondition for a human security policy. But humanitarian intervention is a sensitive and controversial issue. Gareth Evans and Mohamed Sahnoun (2002) claim that if the international community is to respond to the challenge of intervention on human rights grounds, the whole debate must be turned on its head. The issue must be reframed not as a right to intervene, but as the responsibility to protect. It has to be accepted that although this responsibility is owed by all sovereign states to their own citizens in the first instance, it must be taken up by the international community if that first-tier responsibility is abdicated or cannot be exercised. Evans and Sahnoun are not against humanitarian intervention, they are just worried about a variety of interventions disguised as humanitarian concerns. For that reason they underline the principle of sovereignty as enshrined in the UN Charter. However, by doing so, they also stress the responsibility of the sovereign state to respond to its people, which means to provide them with human security, including the protection of the full scale of human rights. If the sovereign state fails to do so, the international community should intervene. But how? According to Evans and Sahnoun, 'coercive measures may include political, economic, or judicial steps. In extreme cases - but only extreme cases - they may also include military action' (2002: 103). This is exactly what happened in the case of Kosovo. All kinds of coercive measures were taken against Yu- 
goslavia including a military action that, in the beginning, was certainly not intended to be a purely humanitarian intervention. Was it justified? Evans and Sahnoun don't answer this question but restrict themselves to a reframing of terminology, from intervention to protection. I doubt whether this will bring us any closer to a consistent theory and practice of humanitarian intervention.

According to the Barcelona Report (2003) a human security policy is a complex operation, involving many actors, last but not least local actors in the area of operation. First, what is lacking in the report is a link between humanitarian intervention (war) and human security. Human security presumes presence on the ground. But how to get there? Perhaps with the consent of the ruling power that is aware (or made aware) of its own incapacity to provide security in its country? Or after a humanitarian intervention (war) when there is no longer a central power in place? The humanitarian interventions in Bangladesh (I97I), Cambodia (I979), Uganda (I979), northern Iraq (I99I) and Kosovo (I999) were all carried out in a classic way, as interstate wars. Even during the course of war, when international or foreign troops are involved, human security operations might take place. However, the Barcelona Report does not deal at all with humanitarian interventions (wars), but seems to focus exclusively on situations where an international presence is already realised, both military and civilian, no matter how the international community had managed to obtain a foothold in the area. Second, what is also lacking in the report is an acknowledgement of the fact that local actors are probably already deeply engaged in human security initiatives from below before the internationals arrive. In the report, the group of local actors is basically defined as a reservoir of consultants, people from whom you can receive relevant information and workable ideas. But a human security policy from above can only succeed if it fully takes into account human security initiatives from below. In other words, the bottom-up approach, advocated in the Barcelona Report, needs to be developed further.

\section{Notes}

I The NATO Cimic Group North quotes on its website a famous statement of General Dwight Eisenhower, who was not much in favour of civil-military relations: 'The sooner I can get rid of the questions that are outside the military 
scope, the happier I will be! Sometimes I think I live ten years each week, of which at least nine are absorbed in political and economic matters ...' (www.cimicgroupnorth.nl). After the Cold War, the perception of civil-military relations has changed enormously.

2 All factual information in this section is based on the chronology of Hasan Nuhanović, unless indicated otherwise.

3 These letters from Iraqi activists can be found on the website of the Interchurch Peace Council (IKV) in the Netherlands, www.ikv.nl.

4 In Iraq, the oppressed majority welcomed the US-UK military intervention as a legitimate means to liberate the country from a brutal dictator, but at the same time they were strongly against U S-U K occupation, not at least for Islamic/religious reasons. See, Oxford Research International's National Survey of Iraq, June 2004: www.oxfordresearch.com/publications.html.

5 Historical notes about the RAF and the Red Brigades can be found on www.duitslandweb.nl/print.html, and http://fsmitha.com/h2/ch27.htm. See also: Die Rote Armee Aufbauen, founding document of the RAF, www.baadermeinhof.com/students/resources/communique/deubuild.html.

6 The Un mission in DRC, MONUC (Mission des Nations unies en République démocratique du Congo), is acting under Chapter vil of the Charter of the $\mathrm{UN}$. It has the mandate to 'ensure the protection of civilians under imminent threat of physical violence'.

\section{References}

AIV - Netherlands Advisory Council on International Affairs (2000), Humanitarian Intervention, Report no.I3; www.aiv-advies.nl / publication / advisory reports, No. I3.

(Barcelona Report) Study Group on Europe's Security Capabilities (2003), A Human Security Doctrine for Europe: Report of the Barcelona Study Group on Europe's Security Capabilities, Barcelona, September I 5, 2003, available online: http://www.lse.ac.uk/Depts/global/Publications/HumanSecurityDoctrine.pdf; also published in: Glasius, Marlies and Mary Kaldor, Eds. (2006), A Human Security Doctrine for Europe: Project, Principles, Practicalities, London: Routledge, pp. 327-356.

Butler, Richard John (2000), Srebrenica Military Narrative - Operation "Krivaja 95", ICTY, The Hague, pp. 25-26.

Bush, George W. (2003), Address to the National Endowment for Democracy at the occasion of the 20 anniversary, 6 November 2003 , www.whitehouse.gov/news/release/2003/I I/2003 I I06-3 html. 
Castells, Manuel (1996), The Rise of the Network Society, Oxford: Blackwell.

Ceadel, Martin (1989), Thinking about Peace and War, Oxford: Oxford University Press.

Club de Madrid (2005), Series on Democracy and Terrorism, Results of the International Summit on Democracy, Terrorism and Security, 8-I I March 2005, Madrid; http://english.safe-democracy.org.

Cortright, David (2004), Civil Society: The Other Superpower, Disarmament Diplomacy, March-April 2004, 4042.

Council of Foreign Relations (2006), Terrorism: Questions \& Answers, http://cfrterrorism.org/terrorism/introduction.html.

Cushman, Thomas, Ed. (2005), A Matter of Principle: Humanitarian Arguments for War in Iraq, San Francisco: University of California Press.

De Wijk, Rob (2000), Pyrrus in Kosovo: Hoe het Westen de Oorlog niet kon winnen en zelfs bijna verloor, Amsterdam: Mets en Schild.

De Wilde, Jaap H. (2003), “De mondialisering van de Monroe Doctrine”, Internationale Spectator, Vol. 57, No. 7/8, pp. 346-352.

Duffield, Mark (2002), "War as a Network Enterprise: The New Security Terrain and Its Implications", Culture Values, Vol 6, No I-2, I January 2002, p I $53-165$.

Eiland, Giora (2006), The Palestinian Authority and the Challenge of Palestinian Elections, Jerusalem Center for Public Affairs, Vol 5 No I6, I.

East-West Network, Giving Real Life to the Helsinki Accords, European Network for East-West Dialogue, I986, Berlin.

Evans, Gareth \& Mohamed Sahnoun (2002), "The Responsibility to Protect”, Foreign Affairs, Vol. 8I, No. 6, pp. 99-I Io.

Faber, Mient Jan and Mary Kaldor (I99I), bCa Mission Report on Yugoslavia, I99I, personal archive.

Faber, Mient Jan (2002), Mission Report of a Visit to Azerbaijan, June 2002, personal archive.

Faber, Mient Jan (2005a), “Srebrenica vanuit een andere hoek bekeken”, in Vrede en Veiligheid, Vol. 34, No. 2, pp. I 56-I7 I.

Faber, Mient Jan (2005b), Peace, Human Rights and the Moral Choices of the Churches, in: Cushman, Ed., 2005: I60-I79.

Faber, Mient Jan (2005c), “Talking to Terrorists in Gaza”, OpenDemocracy, February I 6; http://english.safe-democracy.org/civil.

Faber, Mient Jan (2006), Mission Report of a Visit to Baghdad, June 2006, personal archive.

Galbraith, Peter W. (2006), The End of Iraq: How American Incompetence Created a War Without End, New York: Simon \& Schuster.

Gause III, F. Gregory (2005), “Democracy Alone Can't Defeat Terrorism”, International Herald Tribune, August I 3-I4. 
Gray, Chris Hables (1997), Post-Modern War: The New Politics of Conflict, New York \& London: Guilford Press.

Gray, John (2003), Al Qaeda and What It Means to be Modern, London: Faber $\&$ Faber.

Human Rights Watch, World Report 1999, New York.

Howard, Ross, Francis Rolt, Hans van de Veen and Juliette Verhoeven, Eds. (2003), The Power of the Media: A Handbook for Peace Builders, European Centre for Conflict Prevention and impacs.

Kaldor, Mary (1999), New \& Old Wars: Organized Violence in a Global Era, Chicago: Stanford University Press.

Kaldor, Mary (200I), Beyond Militarism, Arms Races and Arms Control, Essay prepared for the Nobel Peace Prize Centennial Symposium, 6-8 December, www.ssrc.org/sept I I/essays/kaldor.htm.

Krause, Keith (2004), “Is Human Security 'More than Just a Good Idea'?”, Bonn International Center for Conversion, Brief 30 , Promoting Security, But How and for Whom?

Kurth, James, (2002), “Humanitarian Intervention after Iraq: Legal Ideals vs Military Realities”, in Bacevich, Andrew J. and Eliot A. Cohen, Eds., War over Kosovo: Politics and Strategy in a Global Age, Irvington, Ny: Columbia University Press, pp. 87-IOI.

Leezenberg, Michel (2000), "Humanitarian Aid in Iraqi Kurdistan”, Cahiers d'études sur la Méditerranée orientale et le monde Turco-Iranien, No. 29, January-June.

Mack, Andrew and Zoe Nielsen, Eds. (2005), The Human Security Report 2005: War and Peace in the $2 I^{\text {st }}$ Century, Oxford: Oxford University Press, for the Human Security Centre, University of British Columbia, Canada.

NiOD Report (2002), Srebrenica: A 'Safe' Area, Dutch Institute for War Documentation, Amsterdam: Boom.

Nuhanović, Hasan (2003), The Role of International Factors in Srebrenica: Chronology, Comments and Analysis of Events, Sarajevo: Preporod.

Ogata, Sadako, Amartya Sen, et al. (2003), Human Security Now: Final Report of the Commission on Human Security, New York; http://www.humansecurity-chs.org/finalreport.

Pape, Robert A. (2005), Dying to Win: The Strategic Logic of Suicide Terrorism, Chicago: Random House.

Poetker, Joel S. (1967), The Monroe Doctrine, Columbus, он: Charles E. Merrill Books.

Shaw, Martin (I999), "War and Globality: The Role and Character of War in the Global Transition”, in: Jeong, Ho-won, Ed., The New Agenda for Peace Research, London: Ashgate, pp. 6I-80; www.sussex.ac.uk/Usres/gafa3/warglobality.htm. 
Shea, Jamie (1999), The Kosovo Crisis and the Media: Reflections of a NATO Spokesman, Address to the Summer Forum on Kosovo, organised by the Atlantic Council of the $\mathrm{U} \mathrm{K}$ and the Trades Union Committee for European and Transatlantic Understanding, Reform Club, London, July I 5.

The American Conservative (2005), “The Logic of Suicide Terrorism”, Interview with Robert Pape, July I 8, www.amconmag.com/2005_07_i8/print/articleprint.html.

UNHCR, Annual Report I 994, Geneva.

un Report of the Secretary-General's High Level Panel on Threats, Challenges and Change (2004), A More Secure World: Our Shared Responsibility, New York, un A/59/56, www.un.org/secureworld.

Van Tongeren, Paul, Malin Brenk, Marte Hellema, and Juliette Verhoeven, Eds. (2005), People Building Peace: Successful Stories of Civil Society, Boulder, co: Lynne Rienner. 


\section{Human Security from Below: \\ Palestinian Citizens Protection Strategies, 1988-2005 \\ Walid Salem}

This chapter deals with the question of citizens' protection strategies of the Palestinians in the period I988-2005. It compares strategies practised during the first Intifada (I988-1994) with strategies during the second Intifada (2000-today). Before discussing citizens' protection strategies this chapter focuses on components for a framework for citizens' participation in protracted conflict areas. What can such a framework look like? What if these 'citizens' are not recognised as such, but are considered 'subjects' by regimes, clans and families, and also considered to be stateless, or obliged to hold the citizenship of another country? The Palestinians living in Israel are considered by Israel as Israelis or Israeli Arabs. The Palestinians living in Jerusalem are considered by Israel as Jordanians. The Palestinians of the West Bank are considered by Israel as Palestinian residents in an area under dispute, while in Gaza they are considered by Israel as Palestinian residents under the Palestinian Authority (PA). The Palestinians in Jordan are considered by the Jordanian government as Jordanians. Notwithstanding all of this, can they act together in achieving some human security for themselves? These are questions that come to mind in Palestine when the issue of human security initiatives from below is at stake. Human security initiatives in Palestine are characterised by their transformative nature. In Palestine, human security has been promoted through collective campaigns aimed at the realisation of peoples' right of self-determination, including the right of the individual to become a Palestinian citizen, and not to remain 'something' else in the eyes of Egypt, Jordan and Israel and also in the eyes of those who hold power positions in the occupied territories.

If security is the precondition for freedom, receiving Palestinian 
citizenship is a precondition for security, and after that one can attain freedom. Most of the collective human security initiatives in Palestine were non-violent, based on respect for the human security of the other as one's own human security. However, the interference of the factions involved spoiled the initiatives and redirected them in ways the initiators were not aiming at.

\section{Approaches towards Human Security}

The research about human security is still fragile. The United Nations Development Programme (UNPD, I994) deserves credit for initiating the human security approach. However, it concentrates mainly on human security as a 'freedom from want' problem. This way, the human security concept can be confused with the 'human development' concept as underlined by UNESCO (Lee, 2004: 2I). On the other hand, the Canadian and Japanese governments commissioned pioneering research on the physical dimension, that is, the issue of 'freedom from fear'. Moreover, the Japanese pay attention to the combination of 'freedom from fear' and 'freedom from want' (Lee, 2004: 29-30).

Another academic trend in the field of human security is more practical. This school studies human security as a means to transform conflicts. In particular, this research is interested in answering the question of how human security can be realised in concrete situations. Mary Kaldor, the main author of the Barcelona Report (2003), is considered to be one of the pioneers of this trend. Within this school two approaches can be distinguished. One concentrates on the role of the international community in protecting the people in conflict areas. The driving idea behind this approach is the Responsibility to Protect. The other concentrates on initiatives of people to protect themselves, in particular through networks developed for that reason. In Palestine these networks not only protected people but also supported their appeal for citizenship.

If the first approach is isolated from the second, a trusteeship run by external powers might emerge, and in the worst case this will lead to new types of imperialism. Combined with the second trend, however, external intervention can be considered a response to a request from internal networks, in support of initiatives taken by these networks. In other words, the role of the externals comes down to the empower- 
ment of the internals. This can be elaborated in a framework for analysing human security initiatives from below:

\section{A Comprehensive Human Rights and Citizen Rights Approach}

Obviously, in conflict areas, addressing 'freedom from fear' has first priority. This task has to be undertaken by state and non-state initiatives. But 'freedom from want' is needed too. It will take a long time to repair and reconstruct the social fabric of a disrupted society. Success can only be secured if the people themselves are fully involved in these efforts, which requires (among other things) respect for human and civic rights.

One obstacle that may arise is that some of these fundamental rights are said to be contradictory to Islam by some Islamic countries and some Islamic groups. To face this obstacle, public awareness campaigns are needed in which the democratic values embodied in Islam are exposed and a modern reading of the Koran is promoted.

\section{A Transformative Approach}

The advocacy of human security aims at solving some wider issues, such as providing people with 'safety' as well as including them in a 'struggle' for the right to be recognised as citizens (and no longer as subjects), thereby obtaining access to many other rights. In this sense the human security approach is comprehensive and needs to be understood as a process that puts human rights in action. Traditionally, human rights are merely expressed, but within a human security approach they have to be enforced. As a result, transformation of the situation will occur.

\section{A Participatory Approach}

Referring to Robert Chambers (Nelson and Wright, I997: 30-43), participation should not be cosmetic. It should not be based on cooptation, should not be temporary, should not be hierarchical; it should instead be cooperative. Participation is part and parcel of the transformation of a conflict. Through cooperation, a group will protect itself and each of its members. A process of participation will stimulate creativity, and creative initiatives have a better chance to flourish.

\section{An Interventionist Approach}

Promoting human security in conflict areas can be described as a special form of intervention. It is revealing, stopping to remain silent. It 
is against carelessness, against closing your eyes in order not to see, closing your ears in order not to hear. It is a conscious-raising process, asking everybody to take on the responsibility of protection. This begins with protecting yourself, and no longer accepting subordination and exploitation. But protecting another is not a matter of philanthropy; by protecting another, you also protect yourself. Human security intervention starts with yourself, and with the people (group) around you.

Civil society can play its role in the intervention process, including the support of international civil society, which might also directly intervene in conflict areas or, more preferably, in cooperation with local civil society. Human security intervention means defence of human rights, protection of human rights activists and engagement in a process for human rights enforcement.

\section{General and Specific Approach}

The methods of transforming a conflict situation through human security initiatives are diverse. One can embrace a general approach, based for instance on the definition of Espiell (I998: 54): "The very essence of "security" is the fact of being safe, i.e. protected from any danger or risk.' In other words, the fulfilment of Article 3 of the UN Universal Declaration of Human Rights stating: 'Everyone has the right to life, liberty, and security of person' is at stake. Also Kaldor's definition comes close to the full realisation of human security: ' $\mathrm{Hu}$ man security refers to freedom for individuals from basic insecurities caused by gross human rights violations' (Barcelona Report, 2003: 6). Indeed, it refers to the 1994 report of the UNPD (I994: 22-23): 'The main objective of human security is to guarantee the freedom of every individual for the promotion and preservation of his/her wellbeing and dignity.'

A more modest method is restricted to partial fulfilment of human security in situations where complete fulfilment is not possible. Partial fulfilment can even come close to the preservation of the current level of human security in an area. It is a strategy to avoid more harm. The Canadian political scientist, Jorge Nef, states that the main aim of human security is the reduction of risks, and not the elimination of risks: 'The central theme of human security is the reduction of collective (and shared) risk through analysis, decisions, prevention and action aimed at reducing the causes and circumstances of insecurity' (Nef, 2003: 40). In his definition, human security equals the 'reduction and control of insecurity' (Nef, 2003:4I). 
The conclusion is that one should work temporarily for the reduction of harm, until the situation changes for the better. Then, one can move forward with a comprehensive approach aimed at full human security.

\section{An Approach of Nation-Building and State-Building}

The concept of human security is often considered an alternative to the traditional concept of state security. Human security is focused on the individual, whereas state security deals with borders and territory. In Kaldor's terminology: 'The primacy of human rights is what distinguishes the human security approach from the traditional state-security approach' (Barcelona Report, 2003: 6).

Of course, the state itself is to a large extent responsible for the human security of its citizens. Moreover, the state is also committed to international human rights conventions. So, in its foreign policy it has to deal with human security issues too. However, state security is at odds with human security when regimes safeguard their own security at the expense of the security of their people. In that case, citizens are considered a threat to the security of the regime and have to prove their loyalty over and over again. If they fail, their human security is in danger. Human security as a bottom-up approach aims at the realisation of state security structures that express and defend the human rights of their citizens.

In Palestine, where state-building and nation-building are in process, human security can be adopted as an agenda for promoting citizenship. An agenda to: a) promote nation-building - a campaign initiated by equal citizens, who no longer accept the role of subjects and thereby of victims of social, economic and political discrimination; and b) promote state-building - a campaign for a democratic, transparent security system, accountable to an elected parliament, monitored by civil society, and based on the idea of citizens' participation in the security structures, such as community policing. Indeed, in conflict areas there is a great opportunity to build and rebuild official security structures that fit with a human security approach.

\section{Approach of Inclusion of the Other}

Human security should not be divided. It should not be practised inside the borders of one's own country, while that country at the same time violates the human security needs of citizens of other countries. 
This statement is valid with regard to Israel, which works to promote the human security of its citizens while violating the human security of the Palestinians at the same time.

This statement holds too for conflict areas in general, implying that some assumptions of liberation movements need to be challenged. One of these assumptions is that it is necessary to postpone democracy and human rights until the liberation process is completed. (The Fatah organisation in Palestine is an example of an organisation that historically adopted this line of thinking.) This has led to the appearance of authoritarian structures, an obscure apparatus with widespread corruption, clientelism, and the emergence of 'sacred' leaders who are allowed to violate human security, and to deal with people as fuel to be consumed in the revolution, instead of respecting them as valuable in their own right and in need of protection. These practices are often accompanied with a dehumanizing of people from other nation(s).

This logic needs to be reversed. Human security should be considered first priority, even during a conflict. 'Human rights, such as the right to life, the right to housing, the right to freedom of opinion, are to be respected and protected even in the midst of conflict' (Barcelona Report, 2003: I 5).

To conclude: the responsibility to preserve human security, human rights and a democratic process during the conflict is an obligation of all sides involved in the conflict. One could argue that the stronger side should bear more responsibility in preserving human security than the weaker side. This may look obvious to some, but what will happen in the case that only one side (the strongest) is committed to human security and human rights, while the other side (the weaker) is free to do whatever it wants? The seven criteria of this framework will be used to analyse the role of the victim (the Palestinian citizens) in saving its human security in such a way that this is not at the expense of the security of the other (Israeli citizens). A comparison will be made between the first and the second Palestinian Intifada in order to assess if and where the Palestinians were successful and where they failed to provide human security for both the Palestinians and the Israelis. The sections will not give a detailed description of facts on the ground, but will deal with the main characteristics of the Intifadas. A lot of what is written here is based on the personal experiences of the writer, who was one of the leaders 'behind the scenes' in the first Intifada of 1987 to 1994. 


\section{Human Security Interdependence}

Despite the occupied/occupier relationship, human security of both Israelis and Palestinians became intertwined over time in the following way: First, any action against the human security of one party provokes a reaction against the human security of the other party. Second, any improvement in the human security situation of any side shapes the conditions for improvement of the human security situation of the other side. Despite the fact that the Palestinians suffer more and pay a higher price in the present, and despite the relative calm in most Israeli cities, the security interdependence is still there. Acknowledgment will not automatically lead to an improvement in the living conditions of the Palestinian people. Still, one can say that a sense of safety felt by the Israelis will lead to better conditions for the Palestinians and vice versa, at least in the longer run, by paving the way for an end to the occupation.

Third, human security on both sides is intertwined in a deeper way, that is to say that the Israelis belong to the people of the Holocaust, while the Palestinians are the people of Nekba (I948). Of course, there are huge differences between these two crimes against humanity, but both share common characteristics. They are expressions of human suffering. Human security becomes intertwined if each side will show understanding and empathy with the suffering of the other side. This acknowledgment might lead to a breakthrough in their frozen mutual relations (Kaufman and Salem, 2005).

In this context the human security approach will create positive processes for both sides. It helps the Palestinians to find an ethical, non-violent way to get rid of the occupation, while it helps the Israelis to stop dominating other people. This result is of course not guaranteed due to the complexities of the conflict, but still the civic, ethical and non-violent characteristics of the human security approach need to be stressed over non-ethical violence and terror.

This analysis will show that non-violence when practised by the Palestinians became an ethical message of respect for the human security of the other side, showing awareness that human security is interrelated. Moreover, it has been a multiple form of self-protection by the Palestinian citizens: It protected them from harsh Israeli military retributions. It stipulated and ensured that Palestinian citizenship was distinguished from Israeli citizenship. It protected Palestinian social integrity in face of internal fragmentation into tribal, sectari- 
an, and other identities. It protected them through messages conveying the Palestinians' respect for the human security situation of the Israelis: violence was only allowed against objects, not against human beings on the other side.

\section{The First Intifada, 1987-1994}

The first Intifada provides a good example of protection strategies initiated by citizens making use of non-violent means. The aim was to apply the method of self-protection in order to pave the road for a future in which protection is provided by one's own state. Indirectly, human security was also guaranteed to the other side, the Israelis. Because the Intifada was non-violent, Israeli heavy weapons became useless. Moreover, cooperation with Israeli peace organisations in the campaign against occupation also helped to reduce violence (Kaufman-Nunn, I993).

During the first Intifada (at least until I993), military violence of the Israeli occupier was not met with armed violence by the Palestinians. This helped a lot in revealing the real Israeli-Palestinian relationship of occupier versus occupied. That relationship was not disturbed by Palestinian terrorism and a violent Israeli response, as happened in the second Intifada. The use of non-violent means helped Israel to carry out some introspection and to rethink its policies towards the Palestinians. The outcome of this process was an Israeli reappraisal of the PLO and the engagement in secret talks, in Oslo, in I992, which resulted in a declaration of principles in 1993.

Moving from the general to the specifics, the following can be said about the first Intifada, and the protection strategies of the Palestinians:

I) The first Intifada embraced a comprehensive human rights approach by focusing on both freedom from fear and freedom from want. With regard to freedom from fear, priority was given to the issue of 'safety'. Non-violent means were used, but groups of local guards, working in neighbourhoods, villages, cities, and refugee camps, were deployed as well (see, among others. Abdel-Rahman, 1999; Abu Al-Homos, 1990; Ferjani, I990; and Rygbi, r989a-b).

With regard to the freedom from want, an adjusted philosophy was 
developed during the Intifada. Before the Intifada was launched, two competing ideas were present in Palestine regarding the development of the territories. The first one claimed that development is impossible under occupation, while the second spoke about 'steadfast development under occupation'. During the Intifada it became clear that in order to act against occupation in a non-violent way, people should be empowered by the means of the resistance. Accordingly, the idea of sustainable development played an important role in this process (Al-Hadi, I 997). Based on this last idea, the first Intifada developed programmes on household economy, land reclamation, development of national industries, voluntary work contributions to development, social solidarity, and other types of bottom-up communal development processes. These processes failed in practice because of the absence of a strong will, violations, inabilities and so on, but it was still very important that they were there (Samarah, I990).

2) The first Intifada was a transformation process as far as human security was concerned. Until then, the gravity of the Palestinian actions against the occupation was located outside the occupied territories and represented an armed struggle waged by different Palestinian factions. The actions against Israel were rather elitist, since they were carried out by professional people, experienced in the use of arms. Civil resistance was not considered seriously by them and was often disregarded (Hourari, I980). The Intifada of 1987-1994 forced the Palestinian leadership outside Palestine to accept three new realities:

a) The transfer of the gravity of the Palestinian struggle against the occupation from outside to inside Palestine. Thereby, the PLO lost its freedom to attack Israel from Arabic countries bordering Israel (Jordan, Syria and Lebanon). b) The Palestinian leadership began to reassess its position towards the role of citizens in the resistance. Before 1987 , Palestinian citizens were merely considered fuel for the revolution, but the Intifada made it clear that citizens are actors in their own right.

c) These two transformations included a third one: recognition by the Palestinian leadership of the importance of nonviolence as an effective instrument in the struggle against occupation. 
Finally the transformative character of the first Intifada contained an integrative aspect. It brought together most Palestinians, crossing tribal and sectarian cleavages. This highlights a third characteristic.

3) In essence the first Intifada was participatory. Palestinians living on the West Bank and in the Gaza Strip joined in, men and women, young and old, involving all sectors of life, including the economic sector (workers, merchants, civil servants, captains of industry). Moreover, people came from all areas of the West Bank and the Gaza Strip. Women had organised their own higher council (declared on I 8 March 1989), while the youth organised themselves through neighbourhood committees, since the Israeli Army had closed their schools and universities during the Intifada.

Participation was the name of the game in the civic resistance. Everywhere popular committees took the lead. There were popular committees for confrontation with the Israeli Army (Al-ligan Addarebah), popular committees for education, popular committees for guarding, first aid, land reclamation, social solidarity (collecting assistance and distributing it to the poor families), and social reconciliation (active in solving social conflicts ). The Intifada was not spontaneous or lacking organisation. It began spontaneously, but people rapidly organised themselves in creative ways (Samarah, 1990).

Obviously, the different factions and political parties, including the Islamists, were participating as well, in particular in the leadership of the Intifada, which was split between representatives of the PLO factions and the Islamist Hamas. The PLO factions leadership was called the United National Leadership of the Intifada, while the Islamists had their separate leadership that was called 'The Islamic Resistance Movement'. Until I992, the PLO factions leadership worked in close cooperation with the people, leaving a wide space for people's initiatives. In I992, the Palestinian leadership in Tunis began to interfere, however. Orders and statements were issued without consultation. This led to a sharp decrease in popular participation. When Hamas began its terrorist actions inside Israel in I993, it totally killed the first Intifada.

4) In various ways the first Intifada stimulated interventionism. Firstly, intervention by Palestinian citizens: People decided not to leave their fate exclusively in the hands of the armed factions any longer, but to take up their personal responsibility. Secondly, inter- 
vention by Israeli peace groups in support of the Palestinians. A prominent role was played by the Israeli Committee Against the Iron Fist (Warshawsky, 1994). But there were many more initiatives (Kaufman-Nunn, I993). Thirdly, intervention by the international civil society on behalf of the Palestinians: a well-documented case was in the town of But Sahour, where an anti-tax campaign was organised against the Israeli authorities during the Intifada (Al-Shomaly, I99I). Moreover, the international civil society became very active and successful in mobilising public opinion in Europe, the us and elsewhere in the world.

5) The first Intifada was general and particular in its approach. It aimed at a final settlement between the Israelis and the Palestinians. In each and every leaflet it demanded the full Israeli withdrawal from the I967-occupied Palestinian territories. But in the meantime, it called for lifting the checkpoints and curfews and other daily obstacles. It also led the P LO to adopt for the first time the two-states solution in the Palestinian National Council of PLO of I 5 November I986. This impact of the Intifada towards Palestinian political moderation, and political realism needs special study. So, it combined general political demands and the particular daily demands.

The (Intifada) leaflets and statements called upon the people to join the movement of civic resistance activities, and did not call them to use arms (see an analysis of the Intifada leaflets in Al-Adab Magazine, 1990, no. 3-4, pp. 14-30). This served their self-protection, because armed resistance would have provoked devastating retribution by the Israelis. Instead, the first Intifada tried to transform the conflict, to manage it, and to reduce harm by embracing human security strategies. It is worthwhile to note that the Intifada spoke clearly about a Palestinian state on the West Bank and in the Gaza Strip, but not about the liberation of all Palestine, like the Palestinian factions did before 1988 .

6) The first Intifada initiated a process of nation- and state-building. Nation-building was cultivated by bringing people and factions together in cities, villages and refugee camps, where a process of integration took place despite the cleavages. It was also a process of statebuilding. A policy of non-cooperation with the Israelis led to closing down many institutions run by Israelis. Palestinian employees left Israeli banks, Palestinian police officers working in Israeli police sta- 
tions resigned from their jobs and so on. At the same time, Palestinians began to build their own professional institutions. During the Intifada, new professional organisations emerged in many fields, including health, education, research and human rights (Samir Hulieleh, I99I; Taraki, r990; Salem, I999).

7) The first Intifada developed a vision with respect to the rights of the 'other'. The Intifada did not call for the killing of Israelis. Actions were only focused on objects, not on human beings. Important areas of activity included: a) a boycott of Israeli institutions, in particular the Israeli civil administration on the West Bank and in the Gaza Strip, as well as a boycott of all Israeli military departments; b) civil disobedience with respect to Israeli army orders: Palestinians refused to stay at home during the curfews, but left the so-called closed areas or marched in groups towards these areas; c) an economic boycott: no work was done by Palestinians in the Israeli settlements on the West Bank and in Gaza (interestingly, Palestinians stayed in their jobs inside Israel, since this was beneficial for both sides. The Israeli economy needed the Palestinian skilled labour force, and the Palestinians needed income. Israeli products with a Palestinian alternative were boycotted. Israeli banks lost their Palestinian clients. Additionally, taxes were no longer paid); and d) protest activities, such as demonstrations: Palestinians refused to drive their cars with Israeli licences.

Of course, there was not full commitment to this approach. There were always minor groups producing and using Molotov cocktails and knives against Israeli soldiers, but it still fair to say that these tools were used against Israeli soldiers and Israeli settlers, not against the Israeli citizens living inside in Israel. Obviously, since the first Intifada was based on a strategy of non-violence, it led to fewer casualties than the second Intifada of 2000 . According to the Israeli Human Rights organisation Betselem, in the second Intifada 3,269 people were killed as of 30 November 2005 , while I, 420 were killed in the first Intifada. ${ }^{\mathrm{I}}$ Moreover no closures were imposed on the West Bank and in Gaza during that Intifada. The closure began only on $3 \mathrm{I}$ March I993 after Hamas began its terrorist actions against the Israeli civilians inside Israel. In short, it is clear that the first Intifada was aiming at disengagement of Israeli and Palestinian institutions, but not on disengagement at the level of human beings. 


\section{The Second Intifada, since 2000}

Because of its violent nature, the second Intifada raised the issue of Israeli (in)security. Nevertheless, in this period the claim of Palestinian statehood was recognised in the so-called 'Road Map', declared on 30 April 2003 and initiated by the 'Quartet' (consisting of the Us, the UN, the EU and the Russian Federation). However, the Quartet did not introduce a strict mechanism to pave the road towards Palestinian statehood. The American position started from the assumption that a Palestinian state could be realised in 2005. When President Bush was re-elected in 2004, he expressed the hope that the Palestinian state would be established by the end of his second term in 2009. During the meeting between President Bush and the Palestinian President Abu Mazen (October 2005), however, no dates for the establishment of a Palestinian state were mentioned. This was an indication of the failure of the peace process to attain Palestinian statehood, something that led to the success of Hamas in the Palestinian elections few months later. In Israel, positions changed both on the Left and among the ruling Right. Left-wing Israelis, who had often expressed their support for Palestinian statehood, started to talk much louder about the Israeli need for security and urged the Palestinians to fulfil their security arrangements as a precondition for statehood. ${ }^{2}$ On the other hand, the Israeli Right took dramatic unilateral steps in order to improve their own Israeli security without any coordination or cooperation with the Palestinians. One of the alternatives, that is, the 'Unilateral Conflict Transformation' (which required each side to take their responsibilities to transform the conflict, taking in consideration the needs of both sides while doing that), was not chosen (Salem, 2005). The Europeans kept speaking clearly about the right of the Palestinian people to statehood, but now also under the condition that the Palestinians should provide security to Israel first.

The second Intifada had features that were quite different than the previous one. The first one brought the PLO inside Palestine for the first time since its coming into existence, while during the second Intifada the Israelis turned against the PLO and began to delegitimise its leader, the elected Palestinian President Yasser Arafat. Arafat was no longer considered a partner to negotiate with, and was de facto put under house arrest. Under siege, he had to stay in his office in Ramallah until he died in November 2004. Moreover, much of the land 
that Israel had returned to the PLO after and because of the first Intifada was reoccupied by Israel during the second Intifada. The total Israeli withdrawal from the territory of Gaza in 2003 was done purely for Israel's own security and demographic reasons, without recognition of the Palestinian right of self-determination (Salem and Schnell 2004). Still, freedom of movement for the Palestinians outside and inside Palestine is far from realised, let alone the possibility to travel from the West Bank to Gaza and vice versa.

Another big difference was that the first Intifada was a people's revolt against occupation, making use of civilised means that took into consideration the human security needs of the other side. The second Intifada began as civic resistance, but converted quickly into an armed confrontation in which the contradicting views about the failed negotiations in Camp David, between Arafat and the Israeli Prime Minister Barak, were widely publicised. While the first Intifada was a peaceful people's revolt, the second became a violent battle between the elites of both sides who had failed to formulate a shared vision for a solution of the conflict. Each side decided to resort to violence to compel the other to accept under fire what they had each refused to accept at the negotiation table. During the confrontation between the giants, the people at the grassroots level suffered and paid the price in terms of human insecurity. The Palestinians paid the most by far, and not only in human causalities; their economy was ruined as well, and no freedom was left. ${ }^{3}$

There are other views, however. Some - mainly Hamas and Islamic Jihad $^{4}$ - argue that the violence of the second Intifada has had positive effects, in a political way. Among the Palestinians (mainly Hamas and Islamic Jihad), there are people who consider the Israeli withdrawal from Gaza as a victory achieved through the armed struggle. These claims became less convincing when, after the withdrawal, Israel continued to shell targets in Gaza in response to Palestinian rockets launched from Gaza, or for other reasons. Moreover, freedom of movement for the Gazans was very limited, although the border with Egypt is now no longer under Israeli control. Also, on the Israeli side there were those, including the Sharon government, who claimed victory, because Israel was finally able to solve the conflict unilaterally without taking any note of the Palestinians. But there are other Israelis (including Netanyahu, Sharansky and others in the Likud, as well as Uzi Arad from the Herzylia Institute) who openly criticised Sharon. According to them, the withdrawal from 
Gaza was a concession under Palestinian fire. It was a bonus for what they call the 'Palestinian Jihad' or 'resistance'. On the other hand, there are Palestinians who blamed President Abu Mazen for accepting Israeli plans under pressure, instead of insisting on the implementation of the Road Map of the previous agreements between the Israelis, and the Palestinians (see e.g. the articles of the journalist Hani Al-Masri in the newspaper Al-Ayyam, 2004).

All these views are short-sighted. The situation is evaluated from a short-term perspective. The problem is that these views fuel the process of political controversies. Strategic and visionary questions are not raised. Is it really a victory for one side if the other side is still suffering? Is the zero-sum game the only game in town? Do we really want to wait until history takes it revenge? Absent in the discussions is the issue of human security, not only in the long term, but also the actual violations of human security (with long-term implications). The dominant way of thinking is that the other side will always try to sabotage an agreement in order to reach full victory. A win-win situation, a shared victory, cannot be imagined. The first Intifada was based on the idea that 'our' win should not lead to 'their' loss, while the second Intifada was and still is built on the idea that 'our' victory should be paid for by 'them'. From a human security point of view this idea is very dangerous, and might provide further space to the extreme organisations in both sides.

Moving from the overall comparison to some particular features of the second Intifada, the following can be said:

I) The human security approach is absent in the second Intifada. The Palestinian people are used as fuel by the armed groups. When these groups (including the PA security divisions) began to shell the Israeli settlements, they did not care about the suffering the people will have to endure as a result of the Israeli reaction. In other words, people's safety was not on the agenda. Neither were there strategies on how to preserve 'freedom from want', notwithstanding the 'emergency job creation programmes' that were unfortunately far from sustainable. The number of people below the poverty line rose to 38 per cent versus 27 per cent before the Intifada, and the unemployment rate reached 40.2 percent; it had been 30 per cent before the Intifada (UNPD, 2005: 30-32). One of the reasons for these increases is that Palestinian workers lost their jobs in Israel after the eruption of the Intifada. 
2) The second Intifada lacks a transformative approach on the issue of human security. Even worse, instead of enforcing human security, it violated it. And instead of strengthening citizenship and nationbuilding, it created fragmentation inside families, localities and factions. For the people it is obvious to return back to the pre-citizenship bodies for protection, when the overall national bodies cannot provide that protection.

3) Participation was also absent in the second Intifada. The killings by Israel of Palestinians participating in peaceful marches in the first weeks of the second Intifada were used as a justification to adopt a policy based on the principle of 'an eye for an eye'. Violence was answered by violence. It sounded like a call to the people to abstain from participation and to leave it to the armed groups to achieve victory for the Palestinian people. It got even worse when armed groups refused to even participate and make joint decisions with each other, instead choosing to work parallel to each other without coordination, cooperation, or an agreement on one strategy. Some of them embraced a strategy of terrorism against Israeli civilians inside Israel as a response to Israeli state terrorism against Palestinian civilians. Other armed groups focused their actions exclusively on the Israeli army and the settlers in the 1967-occupied territories. The Intifada deteriorated more and more and it reached its lowest point when these splits became visible inside different armed groups.

The most obvious example in this regard is Fatah, which lost its unity while its leadership lost control over the Al-Aqsa Brigades. The Brigades themselves were also fragmented over several warlords. These warlords controlled their own territory and agreed among each other on the geographical distribution of power. Often, the warlords violated the human security needs of their own people. They interfered in social services through the re-channelling of funds and trade-offs with other warlords. They also interfered in the work of the PA security department, taking over law enforcement activities. Moreover, they behaved as judges, for instance by punishing members of the Palestinian Legislative Council in case of a disagreement with Arafat. In Ramallah a lawmaker was shot at, and in Jenin an office of another lawmaker was closed down (see for details the Annual Reports of the Palestinian Independent Commission for Citizens Rights, 2001, 2002, 2003 and 2004).

During the second Intifada, the factions did not distribute regular 
statements among the people as was done during the first Intifada. No popular committees were organised. On the contrary, Arafat worked with loyal people around him and did not make any real attempts towards self-organisations of the people, because for him the Intifada was an instrument to pressure Israel, not a mechanism to mobilise public opinion and to guarantee input from below (Nofal, $200 \mathrm{I}$ ). Because of all of this, there are people in Palestine who refuse to call the actions that took place part of an Intifada (Nofal, 200I).

4) An interventionist approach similar to the one in the first Intifada was absent because people were asked not to interfere. NGOs were summoned to stick to relief activities and services; grassroots organisations of students, women, and others were dissolved or faded away. The Palestinian citizens' interventions that were carried out were justified as measures in response to military interventions of the Israeli Army. Unfortunately, the interventions of international civil society also became problematic, because they were either done in solidarity with one side against the other or were very limited and restricted to marginal solidarity groups. The interventions of the international community became more economic and security oriented. Pressure on the parties to solve their problems politically was almost absent.

With the relative absence of an interventionist approach, human security was not addressed and people suffered, and are still suffering. This has given more work to human rights organisations in documenting human rights violations, and in reporting about them. More than 50 organisations in the PA territories are doing that work, but this intervention is far less than what is needed.

5) Not only was a human security strategy totally missing, there was also no common long-term goal and even the short-term targets were not shared. It was not clear how this Intifada could coincide with a process to end the occupation (the PLO position), or with a full liberation of the old Palestine (the position of Islamic Jihad and, up to a certain degree, also that of Hamas), or only an attempt to pressure the Israelis to implement the Road Map (position of some in the PA), or to achieve a better starting position for the negotiations on the final status (Arafat's position at the start of the second Intifada), or to pressure Israel to return to the borders of 28 September 2000 when the Intifada erupted (the PA's later position). These positions ex- 
pressed nothing less than a total absence of consensus regarding the aims of the Intifada, contrary to the first Intifada where the consensus was very clear.

6) The process of nation-building was also hampered during the second Intifada. What we have seen is the fragmentation of the Palestinian society. Consequently, the process of state-building was also paralysed. Except for the institutionalisation of the ministry of finance and development of hierarchies of the Palestinian ministers, Palestine is facing problems mainly in the areas of security reform, setting up systems for fighting corruption and creating transparency (Development Studies Programme, 2005).

7) The second Intifada was based on an idea of full confrontation, that is, the exclusion of the other. This idea is not part of a planned strategy. The desire for revenge dominated all rational thinking. The human security of another is irrelevant if revenge is the engine behind every activity. The other, whoever it is, is considered the enemy, and thereby a target to be removed (killed). People on the other side are all put in one basket. None is good among them, instead, all are evil.

In this atmosphere, many Palestinian civil society organisations also took the decision to stop all cooperation with the Israeli peace movements. The fundamental disagreement about the stalemate in Camp David was used to justify this decision. The Israeli peace activists were criticised as well for showing no support for President Arafat when he was under siege in his office in Ramallah (Kaufman and Salem, 2005). The second Intifada deteriorated relations between both sides and contributed to dehumanisation of the other.

Crimes against innocent Palestinian citizens, committed by the Israeli army, were the main justification for the Palestinians to resort to violence. Moreover, there were not that many non-violent alternatives left, as well as a weakness in the development of new non-violent alternatives that fit with the new realities. ${ }^{5}$ After Oslo, the tax system was moved to the PA. So, a tax boycott did not make sense. Additionally, the education system was transferred to the PA; strikes made no sense either. A boycott of Israeli products was not possible, because this would be considered a violation of the joint Paris Economic Protocol, which would provoke Israel to stop transferring customs to the PA. Finally, the Israeli army had left the Palestinian cities, so demonstrations against their presence were futile. Moreover, 
demonstrations in the vicinity of Israeli army barracks resulted in even more killings of young Palestinians.

All of these arguments were used, but a creative, new non-violent strategy corresponding to the new political context was never developed. Not even the most visible examples of land grabbing by the Israelis got a serious response. Civic resistance in the areas where settlement expansion took place, or against the separation barrier that was constructed, was never embedded in an overall strategy. There were just incidents. Here and there people acted spontaneously against the wall, such as in the village of Bil'in, but these activities were scattered and uncoordinated, let alone considered part of an overall strategy. Human security paid the price.

\section{Conclusions}

In this chapter I have argued that in a protracted conflict, in casu the Israeli-Palestinian conflict, a human security approach stimulates citizenship, nationhood as well as statehood. This process of building citizenship requires the protection of people, which can be achieved by using non-violence as a tool to overcome the occupation and to engage in internal reform. I have also argued that building citizenship is a precondition for human security in Palestine, as well. Building citizenship is done by the 'subjects' themselves, through a practice of non-violence, calling for the recognition of Palestinian citizenship as part of a struggle in which the protection of human beings is central.

Non-violence as a basis for protection was elaborated in the chapter. It has been illustrated how protection through non-violence can be achieved, both in the short run and in the long run. I have shown how Palestinian non-violence during the first Intifada led in the short run to a neutralisation of Israeli heavy weapons, which in turn led to a better protection of Palestinian civilians. In the long run the first Intifada guaranteed better protection of the Palestinians, because the Israelis were forced to introspection which resulted in the recognition of the Palestinian people for the first time in their history. This was expressed in the preamble of the Israeli-Palestinian Declaration of Principles (the so-called Oslo agreement) of I993. This document also recognised the PLO as the representative of the Palestinian people in the talks. The first Intifada took care of the human security 
needs of the 'other' through its non-violent nature. Consequently, the other accepted the rights of the Palestinians, both as human beings and as a people, for the first time in the history of the conflict. This chapter underlines the idea that human security of both sides in a conflict is intertwined.

Through all its failures, the violent second Intifada proved that non-violence is the road to choose. This chapter argues that the violence of the second Intifada not only led to much suffering for both peoples, it also killed the achievements of the first Intifada. Indeed, the PA areas were reoccupied, the PLO leadership was de-legitimised and a wall was built. The second Intifada produced chaos inside the Palestine society, where armed groups began to rule the streets and undermine the authority of the PA. Arafat paid a high price for what he thought to be a useful tool to pressure Israel. His authority was destroyed and the warlords took over, threatening the human security of the people on a daily basis.

Another conclusion from the comparison of the first and second Intifadas is that people are able to protect their human security in a better way through their own initiatives than political official and unofficial authorities can do. Participation - that is, a bottom-up approach - is crucial for human security. During the second Intifada, people were involved in non-violent activities too. But these efforts were marginalised, not adopted by the PA and the factions, not included in a common strategy, not covered by the media, and not of any influence in the world or upon Israeli public opinion. This means that the PLO, the PA and the political factions should stop excluding the participation of the citizens, and to begin working with the people, and not for the people, moving in this way from being top-down leaders, to becoming members in participatory groups with the other citizens, working together in a participatory bottom-up process for change.

It all resulted in a deep split between the PA and the Palestinian people and in a lot of frustration and despair. The people who had already suffered so much over a long period faced a new catastrophe. The idea that suicide attacks by Palestinian youngsters will put the human security of Israeli citizens in danger and thereby bring a Palestinian victory closer, has proved to be dead wrong. Israeli citizens will only support the rights of the Palestinian citizens when their own human security is not violated, and vice versa.

The Palestinians, therefore, need an integrated human security strategy, which includes roles for the PA, civil society, and individual 
citizens, and that combines 'freedom from fear' and 'freedom of want' issues. In other words, a strategy founded on a communitybased security system. Moreover, it should be a strategy that excludes both internal and external terrorism, leading to a demilitarised state.

\section{Notes}

I Betselem, 2005; www.betselem.org.

2 See e.g. Gershon Baskin's articles at IPCRI-News@googlegroups.com.

3 For details about Palestinian losses during the second Intifada, see the reports of the Palestinian Independent Commission for Citizens Rights, 2001, 2002, 2003, 2004, and the World Bank reports, 200I-2004.

4 See Hamas website www.palestine-info/arabic/hamas and Islamic Jihad website www.qudsway.com/links/jihad.htm.

5 A village called Bil'in close to Ramallah began to develop their nonviolent alternative through weekly non-violent activities against the separation wall beginning from 2004 , but their activities continued to be scattered and were not a part of an overall nationwide strategy.

\section{References}

(Barcelona Report) Study Group on Europe's Security Capabilities (2003), A Human Security Doctrine for Europe: Report of the Barcelona Study Group on Europe's Security Capabilities, Barcelona, September I 5, 2003, available online: http://www.lse.ac.uk/Depts/global/Publications/HumanSecurityDoctrine.pdf; also published in: Glasius, Marlies and Mary Kaldor, Eds. (2006), A Human Security Doctrine for Europe: Project, Principles, Practicalities, London: Routledge, pp. 327-356.

Baskin, Gershon (2005) articles in the website IPCRI-news@googlegroups. com.

Development Studies Programme (2005), Palestine Human Development Report 2004, Ramallah: Birzeit University.

Espiel, Hector Gross ( I 998), “Universal International Security and Regional Security: What Kind of Security?”, Paris: Unesco.

Kaufman, Edy and Walid Salem (2005), "Guiding Principles for Dialogue and Cooperation", Paris: UnEsco.

Kaufman-Nunn, Maxime (I993), Creative Resistance: Anecdotes of nonviolent action by Israel-based groups, Jerusalem: Alternative Information Center. 
Lee, Shin Wha (2004), Promoting Human Security: Ethical, Normative and Educational Frameworks in East Asia, Paris: Unesco.

Nef, Jorge (2003), "Human Security and Mutual Vulnerability”, in: Goucha, Moufida and Francisco Rojas-Aravena, Eds., Human Security, Conflict Prevention and Peace in Latin America and the Caribbean, Santiago: UNESCO/FLASCO, pp 29-6I.

Nelson, Nici and Susan Wright (I997), Power and Participatory Development, London: Intermediate Technology Publications.

Palestinian Independent Commission for Citizens Rights Reports (2001, 2002, 2003, 2004), Ramallah.

Salem, Walid and Schnell Izhak (2004), The Israeli Government Disengagement Plan possible scenarios and an agenda for civil society actions- Panorama Center, Jerusalem:The Palestinian Center for Dissemination of Democracy, and Community Development, Jerusalem Branch.

UNPD (I994), Human Development Report I994, www.undp.org.

World Development Bank, Economic Reports, (2001, 2002, 2003, and 2004), Jerusalem: Biet Hanina.

\section{In Arabic}

Al-Adab Magazine, (I990), "Nida'at Al-Qiyadah Al-Mowahaddah Khilal Assanah Al-Ula Men Al-Entefadah”, No. 3-4, pp. I4-30.

Al-Hadi, Ezzat Abed (I997), “Al-Monadhammat Al-Ahliyyeh Al-Felstineyyah Wa Edarat El-Enteqal men Al-Egathah Ela- Al-Tanmiyyah”, Shu'un Tanmaiyyeh Magazine, Vol. 3-4, pp.76-90.

Abu Al-Homos, Na'im (I990), Al-Felasteniyyon Jeel Al-Entefadah, n.p.

Abdel-Rahman, Asad (I995), "El-Entefadah Al-Felastenieh, Al-Asbab, AlMassar, Al-Nataej, Wa-l-afaq", Qadaya Fikriyyah Magazine.

Al-Shomaly, Gibrael (I99I), Al-Tajrobeh Al-Esyaneyah Fe Beit Sahour: Derasah Moqaranah Bayn Al-Esyan Al-Watani, wa Al-Esyan Al-Madani, Alzahra Center Jerusalem.

Al-Masri, Hani (2004) weekly articles in Al-Ayyam newspaper.

Ferjani, Nader ( I990), “Al-Entefadah Wa Al-Mosharakeh Al-Sha'abiyyah Fe Al-Watan Al-Arrabi”, Al-Mostaqbal Al-arabi.

Hamas website www.palestine-info/arabic/hamas.

Hourani, Faisal (I980), Al-Fekr Al-Seyasi Al-Filastini I 964-I974, Jerusalem: Abu Arafeh Press.

Hulieleh, Samir (I99I) Denamiyat Al-Tanmiyyah Al-Badilah: Nosho'a AlMonathamat Al-Jamaheriyah Fi Al-Aradi Al-Mohtaleh Wa Tataworoha: Afaq Falestiniyyah-Magazine: Birzeit University, Vol. 6, pp. 33-88. Islamic Jihad website www.qudsway.com/links/jihad.htm. 
Nofal, Mamdouh (200I), “Wojhat Nadhar fe Tataworat Al-Entefada wa Ahdafeha”, Al-Derasat Al-Filastenieh Magazine, No. 47, pp.44-59.

Rygbi, Androw (I989a), Al-Entefadah, Al-Neddal Men Ajl Al-Ta'aleem, Jerusalem: Palestinian Academic Society for the Study of International Affairs (PASSIA).

Rygbi, Androw (r989b), Al-Entefadah, Al-Ab'ad Al-Eqtesadeyyah, Jerusalem: Palestinian Academic Society for the Study of International Affairs (PASSIA). Salem, Sari (I990) “Al-Ebda'a Al-Jam'ae, Deraseh Fi Al-Entefadah Al-Felastiniah", Al-Mostaqbal Al-Arabi Magazine.

Salem, Walid (1999), Al-Monathamat Al-Mogtamaeyyah Wa Al-Solta AlWataniyah Al-Falestiniyyah, Ramallah: Mass.

Samarah, Adel (I 990), El-Entefadah Mobadarah Sha'abeyyaeh, n.p., No. 27, pp. 57-73.

Taraki, Liza ( I990), “Qabl Al-Tawafan: Tatawor Al-Wa'i Al- Filastini I967I987", Afaq Felastenieyah, Birzeit University, Ramallah.

UNPD - United Nations Development Programme (2005), “Taqreer Al-Faqir Fi Al-Khalil”, unpublished paper. (Poverty Report Hebron).

Warshawsky, Michael (I994) Ara'a Ha'ol Mo'askar Al-Salam Al-Felastini AlEsraeli, Jerusalem: Alternative Information Center. 



\title{
10 Human Security from Below: \\ Local Security Networks in the Netherlands
}

\author{
Jan Terpstra
}

Up until about twenty years ago, the control of crime and disorder in modern societies was considered to be the task of the police alone. To realise this task the police were granted the use of physical power under certain circumstances. According to this view other agencies, especially private organisations and citizens, should refrain from any active involvement in the institutional control of crime. Fear of vigilantism by citizens was one of the main arguments for why crime control or protection against organised violence should be left to the police. In case of crime or other dangers, citizens were only expected to call the police and report the relevant information to this professional organisation. In this view a constitutional state could not be reconciled with initiatives taken by citizens or private agencies to control crime. In armed societies, like the us, Brazil and South Africa, this logic needs to be put a bit into perspective, allowing for individual self-defence with firearms in case of assault. But here too, society is not expected to organise itself in quasi-military or quasipolice organisations.

In late modern society this Weberian view on the monopoly of the police is becoming undermined. In many Western European countries, the prevention and control of crime and disorder are no longer regarded as the task of the police alone. Other agencies, both public and private, and citizens, individually and as a group, are considered to contribute to the production of security. This has resulted in the rise of all kinds of partnerships, multi-agency networks and joinedup approaches in the prevention and control of crime and disorder, especially at the local level. This development seems in line with the human security perspective that has emerged so far mainly in a for- 
eign policy context. If the international community wants to promote human security approaches, the existing practices in which local self-help initiatives (re-)occur need careful examination. Moreover, in the context of the European Union, Third and Second Pillar concerns get mixed up (see chapters 4 and 5 ). In the quasi-domestic security structure of the $\mathrm{EU}$, it may become paramount to harmonise the emerging human security initiatives from below in order to better control these developments and to subject them to a common legal regime.

Just like in the UK (Crawford, I997), Germany (Lange, 2004) and France (Roché, 2002), the shift from what is called government to governance in the control and prevention of crime and safety problems also occurred in the Netherlands. Today, local security networks can be found in many Dutch urban neighbourhoods, industrial areas, shopping centres and schools. Representatives of the police, local governments, youth work, social work and public prosecution are among the participants of these local security networks, along with citizens and entrepreneurs like shopkeepers. In spite of the gap between the law and order problems in failed states and those in generally stable ones, the underlying logic of self-help has much in common. Wherever people feel threatened and don't trust the official authorities to take appropriate measures, they will start organising themselves along the lines described by Faber, Ben-Ari and Salem in chapters 7 through 9 of this volume. In a context of civil war, self-organising initiatives will be evaluated differently than in a context of peace; they seem to be emergency measures legitimised by human security concerns. Yet their institutionalisation can have lasting effects, and the 'in-between organisations' as Ben-Ari calls them may well cause societal legitimacy problems of their own. This can be better judged from analysing such initiatives in contexts where the crises are not replacing the logic of normal politics.

This chapter therefore deals with local security networks in the Netherlands. In what social and political context did these networks arise? Are there general conditions these networks should meet? What are some of the main problems with which local security networks are confronted? The analysis is based on a study of local security networks in the Netherlands. Eight of these networks were studied in detail (Terpstra and Kouwenhoven, 2004). These networks were established to create solutions for problems with the control of crime and disorder. However, they also produce new fundamental 
problems. The promotion of human security initiatives from below can benefit from better insight in these existing practices.

\section{Social and Political Context}

The rise of partnerships, inter-organisational networks and multiagency approaches in the prevention and control of crime and other safety problems is a part of a general shift in many Western European countries in the relationship between public and private agencies. In many policy domains and social sectors the once-taken-for-granted strict boundaries between public and private are blurred. In many respects the former central role of direct intervention by the government was replaced by coordination or 'steering' at some distance. New forms of regulation have been introduced, like self-regulation (enforced) or the regulatory use of market incentives (Braithwaite, 2000). Former state or public services are increasingly delivered by networks of private and public agencies (Newman, 200I; Pierre, 2002; Van Kersbergen and Van Waarden, 200I).

The rise of local security networks and the parallel shift to a new governance of crime and safety have been interpreted as resulting from the dominance of neo-liberal or neo-conservative politics in the late I980s and early I990s (Stenson, 200I; Stenson and Edwards, 200I). According to this view the policies of the Reagan/Bush and Thatcher/Major governments, with their emphasis on retrenchments of government budgets, cuts in social welfare and the strong reliance on markets and individual responsibilities of citizens, are the general framework in which the rise of partnerships and networks in this field should be understood. Activities that were once the proper tasks of the police and government were cut and transferred or privatised to markets and private agencies.

These changes in dominant political ideology are certainly relevant to understanding this shift from the public to the private. Still, this interpretation is flawed by two limitations. First, it fails to explain why the creation of security networks in the I990s was continued and even accelerated under left-wing governments. This happened in Britain in the I990s. In the Netherlands in that decade, the rise of local security networks was strongly stimulated with the introduction of a local safety policy by the 'purple' (liberal-left) coalition and was given a further impetus with the successful implementation of new 
forms of community policing. Second, this interpretation does not take into consideration relevant social changes in the field of crime, policing and criminal justice. Yet, the rise of local security networks has to a considerable degree been motivated by a complex of social developments with regard to crime control and policing during the last decades.

Like many other Western countries, the Netherlands has a high level of crime, compared with the I950s and I960s (Sociaal en Cultureel Planbureau, 200I). In many respects crime today is more complex, partly because it is to a significant degree disengaged from the local community and relations. During the I990s crime and problems of safety were considered by Dutch citizens as the most urgent problem the government should deal with (Sociaal en Cultureel Planbureau, 200I). Partly this may be the result of the high level of crime in the Netherlands. However, concerns about crime and safety are also associated with more general and diffuse feelings of unease and anxiety about social change. These feelings are translated into worries about crime and migrants (who are primarily seen as causing the high levels of crime), the disintegration of the traditional community, and the erosion of formerly widely shared and accepted norms and views (Bauman, I999).

On the one hand a growing number of citizens seems to be fascinated by the pursuit of excitement and the associated risks. On the other hand, however, people seem to be more concerned about safety risks. Although people often demand freedom and excitement for themselves, they also expect that the government will take care of their safety. This contradictory cultural pattern has been analysed by Boutellier (2004) in The Safety Utopia. The consequence of this cultural pattern may be that the government and public agencies, like the police, are confronted with rising expectations and even demands. This may result in increased pressure for the police and criminal justice agencies but also in a chronic failure to meet these rising expectations. This contributes to a perpetual sense of crisis with regard to the police and criminal justice agencies (Garland, 200I: I920), reinforced by a seemingly endless stream of incidents and scandals. The once deep-rooted respect for authority and legitimacy of the police and criminal justice agencies have now lost their taken-forgranted nature.

Western European governments, also in the Netherlands, have created several, often highly contrasting, strategies to find answers to 
the combination of high-level crime as an integral, almost routine part of everyday life (Garland, 200I) and the decreasing capabilities of the state and the police to meet the high expectations of citizens about the guarantee of safety for all. These strategies may be seen as endeavours to regain legitimacy in the control of crime and insecurity (Crawford, I997: 74-79). Some strategies consist of putting more emphasis on punitive measures, of putting more police on the streets and a strict enforcement of rules. The rise of 'new managerialism' in the Dutch police and criminal justice agencies resulted in new demands of 'value for money', efficiency and performance measurement being imposed on these organisations.

A central element of the reactions to the tensions between rising demands on the police and criminal justice agencies and a chronic shortage of resources is the strategy of 'responsibilisation' (Garland, $200 \mathrm{I})$. Its central message is that citizens, businesses and other private agencies should each take on their own responsibilities in the management of security rather than abdicating these to the police. Public agencies, like the police, try to mobilise citizens and businesses for tasks formerly seen as those of the public police. Both moral and financial arguments are used to legitimise a new division of responsibilities in the governance of crime and public safety.

Local security networks are not only a result of this strategy of responsibilisation by the government or the police. These networks are also established because citizens and businesses are no longer satisfied with the perceived lack of attention paid by the police and local government to their problems of crime, disorder and public safety. Citizens and business firms, especially those who have the resources to do so, increasingly decide to take their own measures to handle problems of crime and safety (for example, by hiring a private security company). This may also reflect a growing social reflexivity (Giddens, I99I) among citizens who want to have the right to decide for themselves how their problems should be managed.

Local security networks may also be a consequence of the erosion of informal and indirect embedded forms of social control. The loss of these 'secondary' forms of social control may be understood as contributing to the growth of new, institutionalised, 'primary' forms of social control (Newburn, 200I), also by creating local security networks. 


\section{Types of Networks}

Local security networks in the Netherlands differ in terms of a wide range of elements, such as their goals, structure, participants, size and methods of intervention. Which actors and agencies participate in a network depends mainly on the kind of safety problems the network focuses on and the prevailing definitions of these problems. Relevant is also the 'technology' (Johnston and Shearing, 2003) used by the network. This requires certain skills, expertise and other resources only some agencies possess. The police participate in all local security networks. Local government is represented in most networks. In some networks only formal institutions participate; other networks may (also) involve citizens and/or entrepreneurs.

The formal goals of local security networks can be broader than public safety problems alone. Some networks, for instance, aim to promote 'the quality of life' in a city centre, the 'economic viability' of an industrial area or 'involvement of all inhabitants' in a neighbourhood.

Most local security networks are the result of a bottom-up initiative. Neighbours, schoolteachers, a group of shopkeepers or community police officers are confronted with some serious problems of crime or disorder. In their view, past strategies have not resulted in successful outcomes and a new strategy is urgently needed, based on cooperation between several agencies and groups of persons. When they have matured, these networks often become as yet integrated in the local safety policy programme of the local government or the policy on community policing.

As a rule, local security networks in the Netherlands combine highly diverse methods of intervention, forms of organisation and styles of cooperation. They combine, for example, changes in the opportunity structure (economic or social), situational prevention (physical), educational measures, social work interventions and recreational programmes with several forms of policing (such as patrol or surveillance by the police, citizens, or private security companies) and repressive methods (like criminal justice measures, alternative sanctions or administrative rule enforcement).

Most local security networks are based upon some formal agreement. Still, the relationships between the partners of the network are often informal. The daily operation of local security networks depends primarily on informal agreements, mutual trust and personal 
acquaintance between the partners. This informal nature creates room for flexibility, a tailor-made approach and for meeting local demands or wishes.

Four Dutch local security networks will be described here in more detail. Generally, local security networks are based upon (combinations of) several underlying security network models. Some networks only have institutional participants. In other networks citizens are also involved. Moreover, network models also differ in their orientation: preventive or reactive. As a result, four models can be distinguished (Terpstra, 2005):

Table 1 Four security network models

\begin{tabular}{lll}
\hline & $\begin{array}{l}\text { Citizens among } \\
\text { participants }\end{array}$ & Institutional network only \\
\hline Preventive/proactive & Participatory networks (I) & $\begin{array}{l}\text { Preventive institutional } \\
\text { networks (III) }\end{array}$ \\
\hline Reactive & $\begin{array}{l}\text { Mixed enforcement } \\
\text { networks (II) }\end{array}$ & $\begin{array}{l}\text { Reactive institutional } \\
\text { networks (IV) }\end{array}$ \\
\hline
\end{tabular}

In each of the four selected cases, one of these models is dominantly present. (For reasons of privacy, the names and locations of these four local security networks have been made anonymous.)

Model I Neighbourhood Action 'Drieluik' Schools

In 1998 and 1999 people living near the three primary schools of the Drieluik area were increasingly confronted with vandalism, disorderly conduct and arson. Most of the incidents were caused by groups of youngsters who were often hanging around near these schools. After another new serious incident, some of the neighbours decided to establish a neighbourhood action group, with citizens, the schools, the community police officer and a neighbourhood office of the local government as its participants. This group was started to enhance the social cohesion in the neighbourhood and to promote the well-being and safety of this area. Citizen members of this group would report problems of safety to the participating institutions, 
keep an eye on youngsters hanging around the schools, and correct their behaviour if necessary. To a certain extent the citizen members operate as a sort of informal neighbourhood watch. Other tasks are left to the participating institutions. Physical preventive measures, like trimming hedges or repairing damage, are the responsibility of the local government. The police are required to enforce a prohibition against entering the schoolyard after sundown.

Although this network certainly also has reactive elements, its dominant orientation is preventive. Therefore, it is an example of a participatory security network. This network is faced with three main problems. First, the participating organisations do not agree on who should coordinate this network. Second, citizen members want to start a new network on their own, because in their view the participating organisations have too much of a 'wait-and-see' attitude. Third, many citizens are reluctant to informally correct others because of lack of knowledge and fear of potential repercussions.

\section{Model II Anti-Hooliganism Network Fc Kerkstad}

Since the I980s FC Kerkstad, a professional soccer team active in the Dutch premier league, has wrestled with a serious problem of hooliganism. Since those years, the club and the police have cooperated to manage this problem. In 1998 the local government, the public prosecutor's office and the association of FC Kerkstad fans joined this security network. This network aims to promote safety at club matches. The members of this network make decisions on the anti-hooliganism policy in this city. They also arrange the distribution of responsibilities between the police and the club, the tasks of club stewards and the transport of the clubs' fans to away matches.

This security network is an example of a mixed enforcement network because control and enforcement of rules have been dispersed in part to other agencies than the police. The club is seen as responsible for the management of measures against hooliganism and disorder within the stadium (including the enforcement of internal rules), whereas the police is primarily seen as responsible for surveillance and control outside the stadium. The management of hooliganism depends partly on administrative measures, for instance with regard to opening hours of bars, which are determined and enforced by the local government. 


\section{Model III Network for Inner City Drug Problems}

A rather complex network with a large number of participants is focused on crime and disorder resulting from the dealing and use of drugs in an inner city. Because of its position near the German-Dutch border and the ready availability of soft drugs in the Netherlands compared to Germany, every week tens of thousands of young German people come to this inner city to buy (soft) drugs (and in many cases also to use them there). Due to the problems resulting from the more or less overt trade and use of drugs, many residents and business owners have left the inner city.

In addition to measures such as strict law enforcement and relocating 'coffee shops' (a Dutch euphemism for bars that sell soft drugs) from the inner city to near the border, it was decided to establish a network with the local government, private investors and housing corporations as the main participants. The goal of this preventive institutional network was to 'revitalise' the inner city by building new houses and shopping areas and to remove the physical opportunities for selling and using drugs. This policy is based on the presumption that a revitalisation of the inner city, in an economic, physical and social sense, was needed as a preventive strategy in this local 'war on drugs'.

\section{Model IV Network on Crime and Disorder by Moroccan Youth}

The neighbourhood Zuidwijk has suffered from vandalism, property crime, and (threats of) violence since I 997. These problems are to a considerable degree caused by a group of about 50 youngsters of Moroccan origin. Several organisations created a network to reduce crime and disorder in this neighbourhood and to prevent serious criminal careers among the members of this group.

This network consists of several elements, including a youth work programme and a group of Moroccan fathers who try to make their own contribution to find solutions for the problems of these secondgeneration youths. The central element of the network consists of an institutional network, with the police, the public prosecution, the youth probation service and youth work as its participants. This may be seen as an example of a reactive institutional network.

Representatives of these four organisations made up a list of Moroccan boys living in the neighbourhood who had recently been in contact with the police. The boys on this list are under close scrutiny by the organisations involved. Every six weeks the representatives of 
the participating organisations meet to discuss the situation of each boy on the list individually to see if he is still involved in crime, which measures have been taken (and what the results are) and to what extent new measures are needed. New boys may be added. Boys who have not been in contact with the police for a fixed period may be removed from the list. Depending on the seriousness of the problems the boys are offered a youth work programme, they may under strict formal conditions follow a youth probation programme, or (for example, if they do not comply with the conditions of the latter programme) they will be sent to the public prosecutor, who may decide to take their case to court.

On the basis of these four cases (and other security networks studied in Terpstra and Kouwenhoven, 2004), the next sections deal with some central elements of local security networks: the dilemmas that these networks face, conditions that are relevant to promoting a goal-oriented approach of these networks and the problem of accountability.

\section{Dilemmas and Preconditions}

Involvement in a local security network may be beneficial for the partners involved for several reasons. Participants may develop better relations with each other and get a better understanding of each other's position, views, expertise and capacities. Informal relations in the network make it possible to bridge contrasting views and potential tensions between the organisations. The close informal relations and mutual trust enable participants to exchange information easily and react to (new) problems with more speed. Because each partner involved has his or her own expertise, resources and capacities, it is possible to have a fairly integrated or holistic approach that uses a wide range of methods of prevention and control. However, local security networks may also meet with all sorts of problems and obstacles. Creating cooperation may take a lot of time and energy. Each of the participants has his or her own views, traditions and interests. Problems of implementation, a lack of coordination and a clash between perspectives, cultures and interests may seriously hamper a network.

An important question is therefore which conditions local security 
networks should meet to enhance their goals and effectiveness. For several reasons it is not so easy to make unequivocal recommendations on the conditions these networks should meet. First, there is a shortage of effect evaluations on these networks. As far as there are evaluations, they concentrate on separate methods of crime reduction. However, local security networks are generally far more complex. As far as effect evaluations of local security networks are available, it often proves difficult to demonstrate their effects (see for example Terpstra and Bakker, 2004). Second, general recommendations are hard to make, because these networks are so different in their goals, the problems of crime they focus on, and their prevailing definitions of these problems. Third, even if these networks concentrate on comparable problems and goals, the concrete form of a local security network is highly dependent on the specific local circumstances and on the demands and wishes of relevant agencies and actors. Fourth, local security networks can be confronted with dilemmas that involve a choice between two values, both of which may be important but which are hard to realise simultaneously (Edwards, 2002: I 45-I 47). In general, it is hard to say how one should deal with these dilemmas. Six of these dilemmas reoccur:

- choosing between an open network (in this case new participants can easily join the network and it can be more responsive to innovations) or a closed network (which may be easier to manage and have a more fixed, recognisable identity);

- choosing between a temporary network (focused on a specific safety problem, but with the risk that each time a new incident occurs a new network must be established) or a structural network (focused on safety as a general problem, which in the long run builds up its own expertise and routines, but which also runs the risk of losing goal orientation);

- choosing between a large number of participants (which may allow an integrated approach) or a small number (which may be easier to coordinate and may be more efficient);

- choosing between an informal network (with more participant involvement and a lot of flexibility, but with the risk of vulnerability and discontinuity) or a more formal struc- 
ture (with a fixed and transparent division of responsibilities, but which may also result in bureaucratic rigidity);

- choosing between citizen involvement (which may promote informal social control and social cohesion) and an institutional network (which may take less time and provides more opportunities to exchange confidential information);

- choosing between effectiveness and formal demands or procedures, for example, with regard to the exchange of information.

Despite these reservations about unequivocal recommendations, some general conditions are important for promoting a goal-oriented approach within local security networks. Here I will concentrate on four organisational conditions:

I According to many participants, local security networks should be based upon informal and close relations between partners, mutual trust, regular exchange of information, flexibility in organisation and in work methods, and a strong focus on the problems concerned.

2 Local security networks should to a considerable degree be based on a bottom-up initiative supported by a coalition of the partners in the network themselves. Partners should share a sense of urgency regarding the problems concerned and the need for a common approach. At least one of the partners should be ready to lead the initiative through its initial phases. Sufficient time is needed to overcome the usual initial problems of the network. Following resource dependency theory (Benson, 1975; O'Toole and Montjoy, 1984), it is important that a majority of the partners perceives involvement in the network as beneficial, for example, increasing the number of clients, domain, status, autonomy or other resources.

3 The relationship between the participating organisations and the network should meet several requirements. First, the participating organisations should support the aims and approaches of the network, both at the street level and management level. Participation in the network should not be in conflict with the general policy framework of the 
organisations involved. Second, representatives of the participating organisations should have enough autonomy to establish operational agreements with partners and to react flexibly to unexpected situations. The internal accountability of workers should not obstruct the activities needed by the network. Performance measurement methods that only recognise internal targets may seriously undermine the participation in a multi-agency network. Coordination is an important element of local security networks. In the Netherlands, local governments have the formal task of coordinating the local safety policy. According to a generally accepted view this should imply the coordination of local security networks.

However, in many cases, Dutch local governments fail to meet this expectation (Terpstra and Kouwenhoven, 2004). Most local security networks are not (or are only to a limited extent) coordinated by the local government. Several factors are relevant here. In most networks several departments of the local administration are involved. However, there is often a lack of internal coordination between these departments, or they may even be in competition or conflict. This may seriously hamper local governments' capacity to coordinate local security networks. Moreover, the coordination of local security networks is often seen as a task of a municipal department of neighbourhood policy or neighbourhood management. However, these departments often fail to realise an effective coordination of the networks because they have a weak internal position and lack competencies and resources.

As a rule local security networks are implementation networks. Municipal officials, however, are often mainly oriented to the formation of policy and are only marginally interested in the daily practical problems of policy implementation. For this reason one of the local governments in our study decided to contract a private organisation to coordinate a large local security network in an area with a lot of bars and discos. The workers of this private organisation had relevant backgrounds and capacities for the coordination of such a network, which municipal officials often do not possess.

Until a couple of years ago the Dutch police often coordinated local security networks. However, a recent demand that management concentrate on the 'core business' and meet internally defined perform- 
ance measures has meant that the police have withdrawn from this task, which is increasingly defined as no longer a proper police task. Because local governments often are not able to take over this position, local security networks face risks because of a lack of coordination.

\section{Accountability of Local Security Networks}

Local security networks may have a serious impact not only on safety as a public good, but also on important social and individual values. These networks can have intended as well as unintended consequences for the open nature and accessibility of public space, the relations between groups of citizens in a neighbourhood, the inclusion or exclusion of certain people or the privacy of individual citizens. Moreover, local security networks may involve the use of formal powers and formal or informal sanctions. Therefore, public accountability should be a central issue for local security networks. This is self-evident in a democratic society, but also in peace-building contexts it should be kept in mind that local security networks at some point have to justify and account for their actions - especially when these involve forms of coercive power.

Due to the complexity and lack of transparency of many local security networks, it is often difficult to get accurate information about each partner's separate contributions to the network. In partnership structures there is often no single identifiable agency which is accountable for the whole network and its outcomes (Crawford, I997: 235). The blurred boundaries between organisations often make it hard to identify which organisations should be accountable for which activities or decisions within the network.

The complex structures and general goals of local security networks often make them somewhat elusive. Moreover, if citizens or particular agencies are interested in getting information on a local security network's activities or decisions, in many cases it will not be clear which agency should be addressed with this request. Many local security networks have no formal procedures for decision making. In general it is unclear to what extent individual partners of a local security network may be held responsible for the activities conducted under the label of the network.

The lack of transparency and accountability also results from the 
highly informal nature of these networks. This may easily suggest to outsiders that the network favours the interests of the partners themselves and that it excludes outsiders from these benefits. Even if this suggestion may be completely wrong, the informal nature and lack of transparency of the network make it hard to deny the assertion.

Local security networks create new dependencies. By participating in these networks, local government and the police may become dependent on the activities of private agencies and actors. This can be beneficial for the private partners in unexpected ways. This may also endanger the legitimacy of the network or of the police and the local government that is supposed to guard the 'general interest'.

In the network for inner city drugs problems mentioned before, five of approximately one hundred coffee shops were tolerated (more or less formally) by the local government and police. The owners of these five coffee shops were even members of one of the working groups in the network. In this way, these five coffee shop owners acquired a strong economic position; their former competitors were eliminated or pushed further into the illegal economy. By tolerating these remaining five coffee shops, the local government grew dependent on these five owners. If these five coffee shops would fail to meet the conditions laid down, the local government would hardly be able to replace them with other coffee shop owners.

The existing structures for an open and democratic control and debate will often fail with regard to local security networks. Citizens participating in these networks are as a rule not representative of the rest of the population. Moreover, the relationship with those they represent is lacking, unstructured or depends completely upon the initiative of these participants themselves. This implies that accountability for a network directly focused on citizens is almost absent and hard to realise.

As a rule the democratically elected municipal councils are also hardly able to control local security networks. These councils often do not have the information needed to do so. More importantly, municipal councils are only allowed to ask for accountability by the local government on local security networks as far as it concerns activities by representatives and officials of the local government. The public-private nature of these networks implies that they are relatively immune to public accountability by an elected body, even if the network is considerably dependent on public resources.

Local security networks are often to a great extent dependent on 
public officials (both police officers and municipal officials). The lack of accountability of these networks may give these officials significant room for discretion. The result can be paradoxical. Local security networks are often intended to give a voice to citizens in the management of safety. However, the lack of accountability and control may in fact strengthen the position and influence of municipal officials.

\section{Concluding Remarks}

Local security networks may promote goal orientation, flexibility, involvement of several agencies, and an integrated or holistic approach to the governance of crime and public safety. However, local security networks often have a deficit of transparency and accountability, a conclusion also drawn in British studies (Crawford, I997: 234-242; Benyon and Edward, 1999). According to Crawford (1997: 260), the shift towards partnerships and networks signals '... a significant detachment of governance from institutional structures of "public will-formation". It is, according to him, a move from 'political' forms of accountability towards 'financial' and 'managerial' models.

Although Dutch local security networks also have a serious democratic accountability deficit, contrary to what Crawford found in the $\mathrm{UK}$, in the Netherlands there is no replacement of the political accountability of local security networks by other financial or managerial forms. The reason is not a lack of dominance of 'new managerialism' in the Netherlands. The Dutch police and criminal justice agencies have had to face the increased influence of the managerial ideology during the I990s. In the Netherlands there has not been a replacement of one system of accountability of local security networks by any other. As far as there is accountability of local security networks, this is fragmented and only partial. The result is that local security networks are often rather opaque for outsiders. In many cases there is a deficiency of accountability even to those who are more or less directly involved in the network.

The lack of transparency and accountability means that local security networks often have a complex and unclear identity. In a situation where everybody carries a small part of the responsibility, it is difficult to explain who is responsible for the whole. This situation 
may impede the process of restoring people's trust in the government or the police. This may be an important reason why, in the early 2000s, the Dutch government has tried to re-establish the image of a powerful sovereign state in the policy on safety. According to this policy the Dutch police have to show their power by imposing more fines and generating more criminal justice cases. More emphasis has been placed on stricter law enforcement, more police and severer sanctions (Terpstra and Van der Vijver, 2006). This endeavour to regain the legitimacy of the state by emphasising the powerful and sovereign state creates a new discrepancy with the actual dispersal of tasks and responsibilities to other agencies and actors than the police or public prosecution. This discrepancy may even increase because of the managerial emphasis in governmental policy which forces the police to focus on so-called core business tasks and to withdraw from local security networks.

This development may have negative effects on the legitimacy, of the police, the state and local security networks. The claim of a strong state in safety policy, with ambitious policy aims on the reduction of crime (in 2002, the Dutch government announced a planned reduction in crime of 25 per cent within four years), suggests that the police and the government are still able to provide solutions for safety problems on their own. However, local security networks prove that the police and the government are strongly dependent on the activities of other agencies and actors, especially at the local level. At the same time, the gradual withdrawal of the police from the local security networks, motivated by the core business ideology, leaves these networks without the necessary powers and professional expertise. A partial involvement of the police may make these local security networks powerless and may seriously undermine their trustworthiness and legitimacy.

\section{References}

Bauman, Zygmunt (1999), In Search of Politics, Cambridge: Polity Press. Benson, J. Kenneth (1975), “The Interorganizational Network as a Political Economy”, Administrative Science Quarterly, Vol. 20, No. 2, pp. 229-249. Benyon, John and Adam Edwards (1999), "Community Governance of Crime Control”, in: Gerry Stoker, Ed., The New Management of British Local Governance, Houndsmills: MacMillan Press, pp. I45-I67. 
Braithwaite, John (2000), “The New Regulatory State and the Transformation of Criminology”, in: David Garland and Richard Sparks, Eds., Criminology and Social Theory, Oxford: Oxford University Press, pp. 47-69.

Boutellier, Hans (2004), The Safety Utopia: Contemporary Discontent and Desire as to Crime and Punishment, Dordrecht/Boston: Kluwer Academic Publishers.

Crawford, Adam (I997), The Governance of Crime: Appeals to Community and Partnerships, Oxford: Oxford University Press.

Edwards, Adam (2002), "Learning from Diversity: The Strategic Dilemmas of Community-Based Crime-Control”, in: Gordon Hughes and Adam Edwards, Eds., Crime Control and Community. The New Politics of Public Safety, Cullompton: Willan Publishing, pp. I40-I 66.

Garland, D. (200I), The Culture of Control: Crime and Social Order in Contemporary Society, Oxford: Oxford University Press.

Giddens, Anthony (I99I), Modernity and Self-Identity: Self and Society in the Late Modern Age, Cambridge: Polity Press.

Johnston, Les and Clifford D. Shearing (2003), Governing Security: Explorations in Policing and Justice, London/New York: Routledge.

Lange, Hans-Jürgen and Jean-Claude Schenck, Eds. (2004), Polizei im kooperativen Staat: Verwaltungsreform und neue Steuerung in der Sicherheitsverwaltung, Wiesbaden: vs Verlag.

Ministerie van Justitie/Ministerie van Binnenlandse zaken en Koninkrijksrelaties (2004), Naar een Veiliger Samenleving, The Hague: Ministerie van Justitie/Ministerie van Binnenlandse Zaken en Koninkrijksrelaties.

Newburn, Tim (200I), “The Commodification of Policing: Security Networks in the Late Modern City", Urban Studies, Vol. 3 8, Nos 5-6, pp. 829-848.

Newman, Janet (200I), Modernising Governance: New Labour, Policy and Society, London: Sage Publications.

O’Toole, Laurence J. and Robert S. Montjoy (1984), “Interorganizational Policy Implementation: A Theoretical Perspective, Public Administration Review, Vol. 44, No. 6, pp. 49I-503.

Pierre, Jon, Ed. (2002), Debating Governance: Authority, Steering, and Democracy, Oxford: Oxford University Press.

Roché, Sebastian (2002), “Towards a New Governance of Crime and Insecurity in France”, in: Adam Crawford, Ed., Crime and Insecurity: The Governance of Safety in Europe, Cullompton: Willan, pp. 213-233.

Sociaal en Cultureel Planbureau (200I), De sociale staat van Nederland, The Hague: SCP.

Stenson, Kevin (200I), “The New Politics of Crime Control”, in: Stenson and Sullivan (200I), pp. I 5-28. 
Stenson, Kevin and A. Edwards (200I), "Crime Control and Liberal Government: The 'Third Way' and the Return to the Local”, in: Stenson, Kevin and Robert R. Sullivan, Eds. (200I), pp. 68-86.

Stenson, Kevin and Robert R. Sullivan, Eds. (200I), Crime, Risk and Justice: The Politics of Crime Control in Liberal Democracies, Cullompton: Willan Publishing.

Terpstra, J. (2005), “Models of Local Security Networks: On the Diversity of Local Security Networks in The Netherlands", Crime Prevention and Community Safety. An International Journal, Vol. 7, No. 4, pp. 37-46.

Terpstra, J. and Inge Bakker (2004), “'Justice in the Community' in the Netherlands: Evaluation and Discussion", Criminal Justice, Vol. 4, No. 4, pp. $375^{-}$ 394 .

Terpstra, J. and Roderik Kouwenhoven (2004), Samenwerking en netwerken in de lokale veiligheidszorg, Zeist: Kerckebosch.

Terpstra, J., and Kees van der Vijver (2006), “The Police, Changing Security Arrangements and Late Modernity: The Case of The Netherlands", German Policy Studies, Vol. 3, No. I, pp. 80-I I I (http://www.spaef.com).

Van Kersbergen, Kees and Frans van Waarden (200I), Shifts in Governance: Problems of Legitimacy and Accountability, The Hague: Netherlands Organisation for Scientific Research (NWO). 

PART IV

Conclusion 



\title{
$11 \quad$ Speaking or Doing Human Security?
}

\author{
Jaap de Wilde
}

In this chapter the issues introduced in chapter I are elaborated in the context of parts II and III: What is the theoretical value of introducing human security as a concept in security studies? What is the practical value of introducing it as a policy device? Along three lines it will be argued that from a theoretical point of view its value is limited, whereas its practical meaning is a mixed blessing, but a blessing nevertheless. The first argument in this chapter is that human security policies from above are dependent on the structure of the international system and the nature of globalisation. This implies that accepting human security as a guideline for foreign politics (or for world politics) is an add-on dimension to traditional security and defence policies: only when state security concerns are in quiet waters, is the shift of referent object to the individual level possible. For human security initiatives from below, an opposite sort of logic is at work: in the absence of a strong state (defined in terms of social cohesion between government and society) the need for small group and individual initiatives is paramount.

The second argument is that, conceptually, human security suggests universality, but its application implies discrimination. Universalising the meaning of human security raises the distinction between external and internal security, and thereby the distinction between political violence and criminal violence. As a consequence, assessing human security boils down to assessing the quality of social-political and social-economic life in general. This implies a world society perspective: an analysis of how 6.6 billion individuals (dis)organise their lives. But even from such a perspective, the distinction between external and internal dimensions of social life immediately resurfaces: 
as soon as social organisation occurs, borders are formed, and borders imply an inside/outside logic. Hence, the referent object of human security moves back from the individual level to the collective one: how do groups relate to each other and how do individuals relate to groups? Among these collectives, sovereign states play a dominant role. Even though economic globalisation and political integration have changed the meaning of sovereignty, its endurance as a pivotal concept in politics is striking (Werner and De Wilde, 200I; Aalberts, 2006), and it comes as no surprise that the human security literature focuses in practice mainly on state behaviour.

In practice, the concept is mainly used in a North-South context, arguing that the North should create human security in the South rather than at home. Chapters 4,5 and Io in this volume show that human security can be of value as a leading concept for the EU's internal security concerns too; which would end part of its discriminatory application.

Inherent to the concept, however, human security also implies discrimination between people: the concept is based on a distinction between victims, offenders and protectors of human security: victims are the good guys who should be rescued, offenders are the bad guys who should be arrested, and protectors are the good guys who should be willing to give their lives for the victims, for example, in humanitarian missions. A similar problem exists for other universal concepts, notably human rights: there are human rights offenders, victims of human rights abuses, and human rights protectors. The crucial difference is that the focus is on 'rights', rather than individuals. Universal human rights describe and prescribe specific behaviour. 'Security', in contrast, has no fixed meaning but is a term to mobilise and legitimise specific (often violent) actions.

Thirdly, it will be argued that the strongest incentive to talk about human security is that it highlights the changing nature of coercive power in world politics. The traditional division of labour between military, police and intelligence is in jeopardy: within the $\mathrm{EU}$, if not worldwide, borders have lost their nineteenth-century meaning and so have the accompanying security perceptions; UN peacekeeping has become police work with military means; globalisation has increased perceptions of sub-state violence; network terrorism works along similar lines as transnational organised crime. The shift from state security to human security captures many of the dilemmas that are involved in the contemporary use of violence. 
In order to assess the value of the human security approach, the next section of this chapter will first focus on demystifying three false arguments in the human security literature that colour the discourse: it is wrongly argued that the post-Cold War world is more insecure; it is wrongly argued that peace is indivisible; and it is wrongly argued that the logic of a human security perspective itself is new. Nevertheless, recent changes in the structure of the international system and in the ongoing process of globalisation do help to explain the background of the human security discourse, as is done in the subsequent section. Finally, the universal ambitions of the human security approach are discussed by relating them to different types of government, concluding that these types of government appear more crucial for designing and implementing human security policies than the shift of focus from the state to the individual level as such.

\section{Myths in the Human Security Discourse}

Myth 1: The Post-Cold War World Is More Insecure

'Freedom from want and freedom from fear': Since the I 994 Development Report of the United Nations Development Programme (UNPD, I994) this motto has gained ground in discussions about peace and development. The link between these two existential features of life has a much longer history. In the I960s Johan Galtung conceptualised 'structural violence' as an expression of this linkage (Galtung I969, I97I). ${ }^{\mathrm{I}}$ In I990, he subordinated the concept to what he labelled 'cultural violence': '... those aspects of culture, the symbolic sphere of our existence - exemplified by religion and ideology, language and art, empirical science and formal science (logic, mathematics) - that can be used to justify or legitimise direct or structural violence' (Galtung, I990: 29I). Direct violence refers to concrete acts of violence (varying from arresting and imprisoning people to wounding or killing them), and is most directly linked to 'freedom from fear'. Structural violence refers to all types of (implicit) discrimination in societies, especially in terms of denying people access to vital sources of existence and development. It is most directly linked to 'freedom from want'.

In the I960s, the military dimension of the fight against direct and structural violence was not as pro-interventionist as in the I990s and 2000s. Every military action was cast or analysed in Cold War terms. 
Even liberation wars (a major wave of decolonisation took place from the late I940s to the I970s) were put in that context: would the new sovereign state join the East or the West? The Cold War dimension was so strong that many observers were unaware that the number of high intensity conflicts after the Cold War hardly increased. According to some accounts, the number even decreased. Since I945, each year there have been approximately i 6 to 25 conflicts with more than a thousand casualties of political violence (Siccama and Anderson, I999). Mack and Nielsen (2005: 23-25) showed that the number of conflicts increased steadily during the Cold War and declined in the I990s. Analysts seem to be missing the orderly logic of bipolarity, and call the world more dangerous today. The myth of growing global insecurity is present in many of the pleas for human security (see, among others, Winslow, 2003: 2; Ogata, Sen et al., 2003: ch.I). The 'new' wars are called transnationally embedded domestic or intra-state wars, and they are analysed in terms of ethnicity, religion, and economic interests, rather than ideology and superpower support. This results in a need for third parties to use a new rhetoric to engage in them. By contributing to the myth of increased insecurity, the human security discourse contributes to such a (pro)active interventionist attitude. This contaminates the logic of shifting from state to human security as such.

\section{Myth 2: Peace Is Indivisible}

One of the other assumptions in the human security literature is that globalisation has reached such levels that global solidarity today is more urgent than in previous centuries or even decades. This assumption is of rhetorical rather than empirical value. 'The whole point of a human security approach is that Europeans cannot be secure while others in the world live in severe insecurity,' the Barcelona Report (2003: IO) argues in its advice to the EU to adopt a human security doctrine. This is the myth that peace is indivisible. It is a myth because it is empirically wrong except for a very limited number of scenarios.

The idea that peace is indivisible, moreover, is far from new. The discovery of global interdependence, with accompanying arguments about the need for global solidarity, took place in the nineteenth century. Explicit references to indivisible peace were already heard after World War I, for example, by the foreign minister of the young Soviet Union, Maxim Litvinov, who saw the need to establish diplomatic 
relations with its non-Communist neighbours. He used the 'indivisible peace' argument to convince both his comrades and his neighbours (Chamberlain, 1947).

The diplomatic appeal of calling peace indivisible is obvious. However, since I945, as ever before, large parts of the world have lived in peace, while other parts were continuously caught in warfare (Volten, 1996). This is not different today. Even in extreme circumstances peace is seldom indivisible: world wars have occurred - drawing large parts of the world into the escalations of regional conflicts but how global is global? While Sikh soldiers were dying in the trenches of Belgium during World War I, its neighbouring country, the Netherlands, managed to stay neutral, and Switzerland has not participated in any world war so far.

Instructive for understanding these margins for choice is Barry Buzan's Security Complex Theory (Buzan, I99I, ch. 5; Buzan, Wæver and De Wilde, I 998; Buzan and Wrver, 2003). The theory is about how human collectives relate to each other and to their natural environment in terms of threats and vulnerabilities. Buzan's application is essentially state-centric, but its logic is not upset when different referent objects are chosen. He defines a security complex as: 'a set of states whose major security perceptions and concerns are so interlinked that their national security problems cannot reasonably be analysed or resolved apart from one another' (Buzan, I99I). Applied to a human security perspective, the definition would read: a set of actors whose major security perceptions and concerns are so interlinked that their security problems cannot reasonably be analysed or resolved apart from one another.

What matters in the context of human security is that we have to establish the salient environment of existential issues for a referent object. This can be humanity as a whole (see below about the complications of doing so), but normally the scope will be much smaller and the choices larger: ${ }^{2}$

- faced with (fear for) a conflict or a crisis, some actors (societal groups, families, individuals) have no choice - they have to run, fight, die or be subjected;

- other actors (neighbours) may fear direct spill-over effects or escalation - they have to take a position (take sides, take over or stay neutral);

- still others can be emotionally involved (by identity ties 
with those directly involved), they can have economic interests in the affected area, or can be confronted with pressure groups or media attention at home, but their own security is not at stake - they can afford to ignore or highlight the conflict.

The regional and local dimension of most existential threats explains why during the I990s the UN was struggling with the legal basis for 'peace enforcement', which requires a threat to international peace and security (UN Charter, Chapter VII). The global solidarity that human security advocates talk about can be a moral imperative, but it is not inherent in the threat scenarios and risk assessments. In her chapter in this book, Mary Kaldor explores the options for broadening the moral imperative, that is, the legal basis for human security policies. She opts for a theory of 'just peace', which addresses both direct and structural violence. This may solve the problems with the un Charter, and it may boost global solidarity. But the above tripartite distinction remains unaltered. At present, both in legal and in practical terms, even extreme situations, like the genocide in Darfur in 2005-2007, still leave the 'international community' ample choice to get involved or not. Normally, there is a choice. Precisely because the notion of indivisible peace is a myth, a human security discourse is needed to achieve the kind of solidarity for which human security advocates hope.

\section{Myth 3:The Global Logic of Human Security Is New}

It is also wrong to argue that the ability and urge to pursue global human security policies is new. The global struggle against slavery dates back to the eighteenth century (and still continues). ${ }^{3}$ With hindsight we can call this one of the first, perhaps the very first, global human security policies, and it was actively pursued by what we would nowadays call civil society organisations. The Red Cross movement in the nineteenth century can be mentioned. The Hague Peace Conferences of I 899 and 1907 can also be seen as an attempt to put human beings as such before elitist state interests. The Communist International, though preaching violence and revolution as the road to success, also had freedom from fear and want at its horizon: a classless society. The twentieth-century struggle for gender equality fits the same logic. Hugo Slim (200I) draws a striking parallel between the 'new knighthood of the twelfth century' (the creation 
of military-humanitarian orders such as the Knights Templar) and contemporary 'violent humanitarianism' as embodied in the publication of An Agenda for Peace (1992) by the then-Un SecretaryGeneral Boutros Boutros Ghali, which launched the discourse on humanitarian interventions.

Pointing at such predecessors may, however, also highlight some peculiarities of the contemporary human security discourse. After the Cold War, older social-liberal ideals of equal individual rights and opportunities merged with optimism about the world's malleability (a new period of Idealism), as well as a propensity to think in terms of risks, threats, precaution and prevention, both stimulating interventionism. Apparently, advocates of human security see a need to move beyond the current human rights discourse. Naming and shaming are the main instruments of Amnesty International and Human Rights Watch. The human rights regime of the UN and other international organisations adds (silent) diplomacy, a bit of international law, as well as discourses about 'good governance' and 'aid conditionality'. But this lacks the activist connotations of calling something a security issue. Such issues take precedence over all other concerns, and imply a need for immediate action - before it is too late (Buzan, Wæver and De Wilde, I998). Turning the human rights discourse into a security discourse adds a level of emergency to it that calls for immediate action - if necessary, military action - or, in other words, humanitarian intervention, or Hugo Slim's (200I) 'violent humanitarianism'. This aptly emphasises the kind of Orwellian newspeak inherent to the human security concept. This fits the wider context of the pro-interventionist discourse in the I 990 (De Wilde, 2006).

The change is not merely discursive. The margins for states and international organisations to deal actively with human security concerns has widened considerably in the I 990 os due to changes in the social-economic structure of the world (the nature of globalisation), and in the power political structure of the world (the nature of the international system).

\section{Preconditions for Human Security}

The New Structure of the International System

The changes in the international system are symbolised by the shift from a bipolar world to a $\mathrm{I}+4$ structure, as identified by Barry Buzan 
and Ole Wrver (2003). ${ }^{4}$ At the global stage there is one superpower, the Us, who is always in play (either active or as a joker in the pack); and there are four other actors (not all of them states) whose views can make a difference depending on the issue area: Japan and the $\mathrm{EU} /$ France/Germany/Britain-combination for mainly economic reasons, the Russian Federation for mainly its geopolitical location and its nuclear capabilities, and China for its growing score on the three most simple of indicators of power (cf. Mearsheimer, 200I), that is, demographic size, military capabilities and gross domestic product. India has abstained so far from expressing global ambitions, but potentially belongs in the same league. Less Neo-realist minds would probably also add the United Nations to that list, arguing that its specialised agencies play decisive roles in large parts of the Third World, while its Security Council is the pivot in debates about war and peace worldwide. Also the G-8 (Canada, France, Germany, Italy, Japan, the Russian Federation, the UK and the Us) is a forum of global importance, adding Italy and Canada to the world's elite, while sidelining China (though China, India, Brazil and the EU may become members).

Irrespective of the precise count of global players, there is relative calm at the global level. Except for China, all players and forums officially support the ideals of democracy, and direct confrontational enmity is absent - though spill-over from regional conflicts is a permanent risk.

Japanese-Chinese relations and us-Chinese relations are tense, respectively concerning their common history and Taiwan. More problematic is regional stability in the greater Middle East due, among other things, to traditional interstate rivalry and military security dilemmas. Potentially, East Asia has similar dynamics. In other world regions, as well as within the geopolitical great powers India and Russia, instability has a different origin: it comes from within. In general, state failure (either as a symptom or a cause of conflict) results in wide-scale political and/or criminal violence, economic breakdowns, absence of educational capacities, (massive) displacement and migration of people, and armed societies. Spill-over into neighbouring countries destabilises entire regions. This is particularly true for parts of Sub-Sahara Africa, parts of Latin America, the Caucasus and, at a smaller scale, the no-go areas in major cities the world over.

The Middle East falls into this category too: its instability is both related to dilemmas of traditional power politics and to weak state- 
society relations. This turns it into the powder keg of the world - the same metaphor as applied in history books to southeastern Europe in the early twentieth century, on the eve of World War I. Then, especially the Austrian and Turkish empires were similarly caught in complex military security dilemmas abroad and ethnic/religious/national separatisms at home.

A potential difference today is that politicians can learn from such a comparison across time. We know that world wars can emerge from regional conflict escalations. We know that all-out war in the Middle East will have global consequences (in some scenarios peace is indivisible), and that its combined internal and external instability poses a global threat because of the region's intertwinement with social-economic and political processes the world over, varying from feeding the oil-based world economy to hosting global terrorist networks. Social learning, however, is only a potential: the lessons can be missed, or they can be wrong.

In general, it can be concluded that at the global level there is no resistance to the dominant powers engaging in a human security discourse, and at the regional and local levels there are plenty of incentives to do so. It can also be concluded, however, that human security 'from above' is an add-on dimension to traditional security concerns. Only when enmity/amity patterns and international power configurations are favourable, is the shift in referent object from a human collective (the state, the nation) to humans as individuals possible. (As will be argued in the section below about types of government, this logic does not apply to human security from below.)

\section{The Youngest Phase of Globalisation}

Globalisation is far from new. The political awareness of global interdependence, that is, the establishment of globalisation as a social fact, was widespread in the late nineteenth century, while some of its material features (e.g. world climate change and its biological consequences) predate the birth of humanity (De Wilde, I99I: Ch.I). Yet, it is correct to maintain that the micro-electronic revolution of the late twentieth century implies fundamental change in terms of altering the conceptions and consequences of time and space (Rosenau, I990; Scholte, 2000). Speculating on the nature of these consequences is good sports in all social sciences, and the bottom-line is we do not know (though history will probably prove some visionary scholars to have been visionary indeed); however, the fact that the 
world looks different since the introduction of, say, the personal computer merely a generation ago in $\mathrm{I} 98 \mathrm{I}$ is undeniable.

The argument that these changed structures of social time and space imply a utilitarian or moral need for global solidarity is romantic and logically wrong. Romantic is the image of a global village where everyone knows each other, is linked to each other and dependent upon each other. Even in villages this image is wrong (most violence occurs in the private sphere). As I have often argued before (including in De Wilde, I994; I996), the metaphor of a dirty megalopolis is more appropriate. This is a world of slums and no-go areas fenced off from villa districts, voluntary apartheid from quarter to quarter (gated societies), zones of turmoil ruled by unstable gangs and warlords, next door to zones of peace ruled by bourgeois middleclass regimes. At a global level, the world consists of about I billion people in extreme wealth (struggling with freedom from over-consumption rather than freedom from want) and about I billion people below the poverty line. The rest, roughly 4.6 billion people, live somewhere in between, fearing to join the poor, hoping to join the rich. At regional and local levels this division plays out in a wide variety of ways - but it seldom leads to philanthropy by the rich and willing compliance by middle-class losers. (In terms of political activism, the really poor are not the problem. Their agenda does not offer much space beyond direct survival concerns; Græger and Smith, I994.)

Logically wrong is the idea that closeness between people leaves no choice but solidarity. Isolationism and imperialism are clear alternatives, well-tested throughout the twentieth century (De Wilde, I99 I; 1994; Elias, 2000). Even if they may turn out to be counterproductive in the long run, there is no guarantee that they won't be tried in the short run, time and again. The problem of solidarity is that the counterpart needs to opt for solidarity too. If not, attempts at solidarity end in defeat - call it a 'solidarity dilemma' - which is not necessarily a dilemma for the 'top-dogs'. This is most obvious in regional security complexes where interdependence is extremely high and peace is almost indivisible indeed, as in the Middle East. All features of the global interaction capacity are thicker within this region than in the world at large. If they do not lead to solidarity in the Middle East, why would they worldwide?

Still, it can be argued that the youngest phase of globalisation leaves no choice but to intervene actively in all quarters of the global mega- 
lopolis. This is most obvious in the Global War on Terrorism launched by the us after September II, 200I, commonly known as nine-eleven. 5 Due to globalisation, one of the new threats to the structure of the international system is catastrophic terrorism: the ability of an otherwise small actor to alter the course of history by deploying extreme direct violence. Though nine-eleven does not fit this category, its psychological impact on the world's only superpower has been such that it altered the course of history indeed. ${ }^{6}$ This dimension of globalisation (the individualisation of the ability to inflict catastrophic damage) has added a motive to the need to take a new class of non-state actors - ordinary individuals - seriously when analysing the stability of global structures. 'Ordinary' needs to be emphasised: 'exceptional' individuals (political, religious, cultural or academic leaders) colour history books worldwide.

Advocates of human security can and do exploit the fear of catastrophic terrorism in their attempts to get their arguments accepted by the advocates of traditional state security: in their eyes human security has become a precondition for state security. This linkage can be found in various reports that try to influence the security policies of states and international organisations (see e.g. the Barcelona Report, 2003; Mack and Nielsen, 2005). The authors like the dominant powers to grasp the occasion and profit from the niche history seems to offer, be it in different ways than they are doing. The best way to fight terrorism, the argument goes, is to switch foreign policies from state security to human security. Globalisation, now and in the past, offers opportunities for a liberal-socialist agenda of providing equal chances to all people on earth. The micro-electronic revolution offers new opportunities for collective action and sharing solidarity. ${ }^{7}$ Catastrophic terrorism seems to show the price of failure: if a human security perspective is neglected, the dark scenarios of Huntington's ( I997) clash of civilisations, Barber's (200I) Jihad versus McWorld, and Kaplan's (2000) global jungle may come true. The human security discourse is about grasping chances for the better.

\section{Universal Values? Universal Consequences!}

Therefore, human security is first of all a policy agenda: if we have entered a network society, let's build networks indeed to create freedom from fear and want in every corner of the world where it is ab- 
sent or under pressure. So far, however, the literature on human security does not cover 'every corner', but mainly focuses on interventions in the Third World. It expresses concerns well known from Development Studies and adds a proactive attitude. Human security is developed as a typically 'northern' or 'western' concept to be applied to developing countries. Both politically and conceptually this is a questionable limitation.

The original document on human security is more subtle in its language than suggested here. 'Human security is also a universal concern', the UNPD Development Report 1994 claims, 'threats are common to all people and components of human security are thus interdependent' (UNPD, I994: ch. 2). Then the myth of an indivisible peace enters the stage: 'On a global level, one must also acknowledge that when human security is threatened somewhere, it is under stress everywhere' (UNPD, I994: ch. 2). Subsequently, the corners of the world where hardship is worst are pushed to the front; all of them are located in the Third World. This is a development report, not an annual report of, say, the world's stock markets, where global threats would be cast in different terms. The claimed universality of human security turns out to be a plea for increasing development funds worldwide. Nothing wrong with that, but it is not based on a proper analysis of what human security means in universal terms. Its presumed universality is merely a selling point.

Conceptually, human security breaks with the dominant referent objects of security: the territorial state and the national state. Instead it puts the individual in the spotlight. Doing so has far-reaching consequences. It makes human security a logical companion of the concept of human rights. Irrespective of the debate of whether human rights are truly universal or culturally distinct (a debate that centres on the issue of whether the individual - every individual - is ultimately sovereign or is ultimately a member of a collective, and thus subjected to the culture of that group; Donelly, 2002), the human rights discourse has resulted in an agenda that does not distinguish North from South or East from West. Proof of this is that the most sophisticated human rights regime exists in and for Europe. Despite its shortcomings (mainly due to its limited budget), the European Court of Human Rights is at the service of the about 730 million inhabitants of the 46 member states of the Council of Europe. Helped by human rights NGOs and, at times, the media, the Court is a check on public policies, resulting in some $\mathrm{I} 4,000$ cases a year in which citizens take 
issue with their government, the tip of an iceberg. ${ }^{8}$ Politically, the Council of Europe performs important watchdog functions; ${ }^{9}$ which perhaps explains why the member states keep its budget so low.

The concept of human security only makes sense if it can function in a similar, corrective way. In this book, therefore, the chapters about human security concerns related to the Middle East (by Eyal Ben-Ari and Walid Salem) are put in sequence with an analysis of local security networks in Dutch society (by Jan Terpstra). More generally, if we want a focus on human security it should focus on all situations in which freedom of fear and want is absent, either structurally or temporarily.

Hence, if poverty is the issue, it is not just India's poverty but also the poverty in the US or in Poland. In 2005, the Indian government estimated that $260-290$ million of its people were living in poverty, and according to World Bank criteria, 390 million Indian people were earning less than one us dollar per day, which the World Bank calls the poverty line. ${ }^{10}$ In Poland, 7 million people were reported to be living in poverty in 2005 , and in the Us, 37 million people. ${ }^{\text {II }} \mathrm{A}$ human security strategy can only make sense when all these people are attended to with similar concern and urgency. ${ }^{\mathrm{I} 2}$ Yet fighting poverty in the West is not a prominent issue in the human security literature.

If violence is the issue - that is, the chance of being robbed or murdered, for whatever the motive - not just Liberia's anarchy needs attention, but also the anarchy in parts of, say, the state of California. In 2003, almost 2,000 killings occurred in Liberia, which triggered an international response that brought the figure back to 25 victims of political violence in 2004. ${ }^{\mathrm{I} 3}$ In 2002, California witnessed 2,395 homicides, according to the Us Department of Justice's Bureau of Justice Statistics, but California cannot be found in any international statistics on violent deaths. ${ }^{\mathrm{I}}$ These statistics are mainly geared towards political violence (that is, violence inflicted by or directed against governments and politicians). Though this makes the comparison with Liberia skewed (I did not find homicide numbers for Liberia), it can still be argued that, from a human security perspective, the homicide rate in California needs to be treated with the same concern and urgency as the killings in Liberia. But when will the UN send troops to California?

In terms of human security it makes no sense to distinguish political violence from other forms of violence. Consequently, if we want 
to single out political violence as a special class of security concerns, it becomes murky and confusing to address this in terms of human security. Why should we risk the life of one individual to rescue the life of someone else? Humanitarian interventions raise such discussions. Many people in the West who joined the army during the Cold War (often as conscripts) did so in order to protect their country - and by doing so, obviously also the people living there. State security implies a clear hierarchy in values: the life of an individual weighs less than the survival of the collective, that is, the state (or its government), and the life of a soldier weighs less than that of a civilian. In human security all lives ought to weigh the same, which creates a paradox for the state that enforces such a policy upon its subjects. In the early I 990 , professional soldiers and officers questioned why they should risk their lives in peacekeeping operations for people they did not know. Were they to become 'armed street workers', risking their lives in the no-go areas of the world for people who did not share their culture and language?

The us-led humanitarian intervention in Somalia (I992-I993) not serving any clear national interests in traditional terms - was cancelled shortly after i 8 us Army Rangers were killed. In his evaluation, Walter Clarke, Deputy Chief of Mission 'Operation Restore Hope', expressed his hopes that the lesson of this intervention will not be that humanitarian interventions will disappear: despite the mismanagement, 'an estimated I0०,००० lives were saved' (Clarke and Herbst, I996). Yet, he and co-author Jeffrey Herbst rightly noticed how the 1995 edition of Un Secretary-General Boutros Boutros Ghali's An Agenda for Peace 'expressed less optimism about the possibilities for intervention than he did in the I992 (first) edition ...' (Clarke and Herbst, 1996). Genocides in Rwanda (around 800,000 Rwandans, mainly Tutsis, were killed within three months in 1994) and in Sudan (the systemic killing of black people by Janjaweed militias in Darfur since 2003 , resulting in about 400,000 casualties and 2.5 million displaced people in April 2005, were and are largely neglected by the 'international community'. ${ }^{\mathrm{I}}$

Apparently, humanitarian concerns alone are insufficient to put the lives of 'human security soldiers' at risk. This can be linked to the indivisible peace argument: for direct interventions, higher stakes are required. The 2006 war between Israel and Hezbollah immediately upset politics worldwide. Catastrophic escalation scenarios in the Middle East are much closer to the politician's, the journalist's and 
the academic's minds than common fate scenarios related to remote suffering. Hence, in the context of discussions about third-party interventions, the human security argument is mainly a trump in the hands of those favouring more active (military) involvement in the many high and low intensity conflicts worldwide.

The Human Security Report 2005 (Mack and Nielsen, 2005) tries to break through the Western bias of the concept by also looking at crime-related victims, but the attempt fails methodologically. The authors aggregate their figures at the state level, which, due to differences in size, leads to all kinds of statistical distortions. Moreover, crime figures are not yet included in their Human Security Index (HSI) (Mack and Nielsen, 2005: 92). The HSI is solely based on criteria related to political violence, human rights abuse, and state (!) stability. This way, human security remains an issue for rogue states and failed states only. Statistically stable democracies appear immune for human security offences. A different aggregation of facts is needed to escape state-centric and political-violence-based representations of human security. This is easier said than done. The HSI suffers from the same problems as the Human Development Index (HDI) or all other attempts to put individuals before states. Fact finding is often based on data aggregated at the state level; it follows birth registers, tax regimes and crime records of governmental bureaucracies (all of which, by the way, shows the continued dominance of the state system in understanding the problems of globalisation).

\section{Searching for the Human in Human Security}

Who then defines which humans need protection and which humans should risk their lives to provide this? For protection the emphasis tends to be on the weak and oppressed 'ordinary' people. But are they at stake as individuals or only as a group? If they are at stake as a group, we do not need the concept of human security to deal with them: if group identity comes before the individual, this can be better defined in terms of societal security (Buzan, Wæver and De Wilde, I998; Wæver, Buzan and De Wilde, forthcoming). When the individual is pushed forward, this is often to represent the group's case: pictures of tortured or starving people, for example, generally are about the situation in which the violence occurs, not about the particular individual portrayed. 
When people are at stake as individuals rather than symbols, insoluble contradictions emerge. The security of high-placed officials, politicians, businessmen, artists and so on traditionally has been the subject of individual security policies; this is expressed well by the word 'bodyguard'. But how to protect the life of an individual when the life of the bodyguard is as important as the life of the president $\mathrm{s} /$ he protects? Now, the difference is in what they represent in society. Media are more concerned about civilian casualties of political violence than about military ones. It makes a difference if getting killed is part of your professional risks or not. The price of blood depends on social structures. Human security advocates suggest these societal differentiations should be lifted, but can we have social life without Galtung's 'cultural violence'? A complete liberal interpretation of human security would boil down to nineteenth-century anarchism. This again shows its theoretical shortcomings. But for its practical usage, one does not need to go that far. In practical politics human security works to counterbalance dominant security policies. It is not about designating individuals as referent objects, but about countering dominant state-centric thinking.

\section{Types of Government and Human Security Initiatives}

The human security discourse gives expression to the apparent need to rethink the sovereignty-based distinction between internal and external security as it is taught in textbooks. Traditionally, the security concerns among people within a society are defined in different terms than security concerns between societies. Within societies, security discourses are about law and order. Between societies, security discourses are about war and peace. Within societies, police forces form the coercive element of governance. Between societies, military forces form the coercive end. The sovereign state functions as the pivotal actor in this logic. Therefore, from a traditional perspective, state security comes first.

The conceptual and geopolitical borders between police and military tasks, however, are disappearing as a result of the processes described above: a new phase of globalisation combined with a new political world order. Historically, the military serves the state and the state only. Its proper place is in the barracks. Only in times of existential threats to the state is it needed in society. In autocracies, its socie- 
tal presence is permanent, and its role is repressive (because the existential threat to the state, read: ruling elite, is perceived to be permanent). In all other types of regimes, its main focus is on external threats to the state.

Originally, police forces also protected first and above all the interests of the ruling elite, but they emerged in urbanised contexts where they gained more general roles in directing daily affairs of human traffic (Tilly, I990). Their proper place is in society, where they permanently deal with law and order issues. Together with the judiciary and penitentiary institutions, police forces determine the quality of the legal order, as concluded by Tor Tanke Holm and Espen Barth Eide (2000), years before the world was confronted with the drama in Iraq. Their main focus is on internal security - in most states combining state and human security concerns.

Crossing both spheres is the role of intelligence: secret services operate across borders (often using diplomatic channels) to estimate aggressive intentions and capacities of foreign governments or, nowadays, terrorist networks, and operate in the private sphere of citizens at home and abroad to estimate revolutionary intentions and capacities of oppositional groups. So far, intelligence, like the military, only serves state security (Scott and Jackson, 2004). A human security perspective intends to change this, but the historical legacy is huge.

The operational aspects of such a change have been put on the agenda (see the Barcelona Report, 2003; Coker, 200I: ch. 5; Winslow, 2002; and chapter 6 by Joseph Soeters in this volume) but there are also conceptual aspects. The concept of human security can only make sense if the freedom from fear agenda covers the whole range of manifestations of violence against individuals. In this respect, Caroline Moser (2004: 5) provides a useful overview of the types of violence that should be part of the Human Security Index. She aims at analysing urban violence, but in face of globalisation this urban agenda and the global agenda are largely the same. Terrorism needs to be added to the manifestations of political violence she mentions, but this agenda covers what should and should not be covered by a human security agenda fairly well (compare the comprehensive human security agenda drafted by Hans Günther Brauch, 2005: 22$25,74-77)$. 
Table 1

Roadmap of categories, types and manifestations of violence in urban areas

\begin{tabular}{lll}
\hline $\begin{array}{l}\text { Category of } \\
\text { violence }\end{array}$ & $\begin{array}{l}\text { Types of violence by perpetra- } \\
\text { tors and/or victims }\end{array}$ & Manifestations \\
\hline Political & State and non-state violence & $\begin{array}{l}\text { Guerrilla conflict } \\
\text { Paramilitary conflict } \\
\text { Political assassinations } \\
\text { Armed conflict between political } \\
\text { parties }\end{array}$ \\
\hline Institutional & $\begin{array}{ll}\text { Violence of state and other } \\
\text { 'informal'institutions } \\
\text { Including the private sector }\end{array}$ & $\begin{array}{l}\text { Extra-judical killings by police } \\
\text { Physical or psychological abuse by } \\
\text { health and education workers } \\
\text { State or community vigilante- } \\
\text { directed social cleansing of gangs } \\
\text { and street children } \\
\text { Lynching of suspected criminals by } \\
\end{array}$ \\
& & community members
\end{tabular}

\begin{tabular}{lll}
\hline Economic & Organised crime & Intimidation and violence as \\
Business interests & means of resolving economic \\
Delinquents & disputes \\
Robbers & Street theft, robbery and crime \\
& Kidnapping \\
& Armed-robbery \\
& Drug-trafficking \\
& Car theft and other contraband \\
& activities \\
& Small-arms dealing \\
& Assaults including killing and rape \\
& in the course of economic crimes \\
& Trafficking in prostitutes \\
& Conflict over scarce resources \\
\end{tabular}

\begin{tabular}{lll}
\hline $\begin{array}{l}\text { Economic/ } \\
\text { social }\end{array}$ & $\begin{array}{l}\text { Gangs } \\
\text { Street children (boys and girls) } \\
\text { Ethnic violence }\end{array}$ & $\begin{array}{l}\text { Territorial or identity-based 'turf' } \\
\text { violence, robbery, theft } \\
\text { Petty theft } \\
\text { Communial riots }\end{array}$ \\
\hline Social & $\begin{array}{l}\text { Intimate partner violence } \\
\text { inside the home } \\
\text { Sexual violence (including } \\
\text { rape) in the public area } \\
\text { Child abuse: boys and girls } \\
\text { Inter-generational conflict } \\
\text { between parent and children } \\
\text { Gratuitous/routine daily } \\
\text { violence }\end{array}$ & $\begin{array}{l}\text { Physical or psychological male- } \\
\text { female abuse } \\
\text { Physical and sexual abuse, part- } \\
\text { iculary prevalent in the case of } \\
\text { stepfathers but also uncles } \\
\text { Incivility in areas such as traffic, } \\
\text { road rage, bar fights and street } \\
\text { confrontations }\end{array}$ \\
& Arguments that get out of control
\end{tabular}

Source: Moser, 2004: 5. 
Do we really want human security to cover all of this? Conceptually there is little choice. This is the minimum one gets filling in a notion like 'freedom from fear' at an individual level: from a violent husband to nine-eleven, from a street murder to a holocaust. Interestingly, the only way to get a grip on this is by shifting the analysis back from the individual's fear to the social contexts causing it. Hence the perceived quality of the society and its governance - the overall social-political situation - becomes the actual indicator of human security.

In this context it makes sense to link the concept of human security to Barry Buzan's distinction between strong and weak states (Buzan, I99I: 96-107), and to stretch its logic to incorporate sub-state governmental levels such as provinces and (especially) major cities. The weak/strong distinction rests on the degree of social-political cohesion within the unit under consideration. Cohesion is high for strong units and low for weak ones (hence strong or weak is unrelated to military or economic power). The urban level deserves separate attention because half of the world population lives in urbanised areas, and most of the public violence occurs there (Axworthy, Fallick and Ross, 2005; www.citymayors.com).

The notion of strong and weak government can be related to the level of repression a government uses to stay in power. The higher the budgets per capita for policing, domestic intelligence (spying), and domestic deployment of the military are, the weaker the government. The higher the perceived need to lift (part of) human rights or the more often emergency situations are declared, the weaker the government. Phrased differently, the more the manifestations in Moser's table occur, the weaker the state and the stronger the urge to replace state-centric security policies by local initiatives. Human security initiatives from below can be expected in reaction to weak states.

Weak states come in two forms: cases of failing government and cases of repressive government. In the first case, the public sector has lost its protective functions. In the second case the private sector has lost its protective functions.

In the failed state scenario the public sphere disappears, and all politics becomes private business. Out of this situation, in the longer run, new state formation processes may emerge. Charles Tilly (I990, I994) has provided a by-now classic account of how the monopolisation and merger of capital and means for coercion has been at the root of state formation processes in Europe. The third crucial ele- 
ment is group identity: the sharing of myths about origin, solidarity and destiny, varying from kinship and nationalism to religion and ideology. Obviously, the three elements, carrots, sticks and groupthink, have an impact on each other. Human security concerns seem to be at the basis of this, but it takes a (violent) form the literature does not seem to welcome.

Bayart, Ellis and Hibou (I 999) point at a bottom-up state-formation process in parts of Africa, where so-called ethnic wars in fact boil down to a version of gang wars about control of natural resources like diamond mines. Similar developments take place in other parts of the world, notably Colombia. It is the logic of inner city warfare: territorial control as a basis for exploitation (taxation). If the ruling criminal organisation (the elite) does more than spread fear, and also renders social public services, including education, external security and administration of justice in private conflicts, it will gradually gain some legitimacy. Ultimately, the leviathan may be tamed, and the government becomes the servant of its subjects, and sovereignty rests with the people - a so-called process of democratisation. ${ }^{16}$ In the absence of a well-functioning public sector, human security from below begins as a self-help policy.

In the chapters by Mient Jan Faber, Walid Salem, Jan Terpstra and Eyal Ben-Ari, practices of such policies are discussed. But in the cases discussed by them, there are still established authorities involved, either local ones or intervening third parties. The human security policies they describe go beyond self-organisation. They are also about a struggle for power against other groups in society: one self-help group against another, and all of them trying to achieve outside support of potential allies for their cause. A problem for theorising human security initiatives from below is that the same logic applies to criminal groups in weak states. André Standing (2003) provides a telling case study about organised crime at the Cape Flats in Cape Town, South Africa. He shows that organised crime represents 'a rational response of survival and resistance' and that the 'crime bosses derive community toleration and respect by performing functions traditionally associated with the state' (Standing, 2003: I, 9). Advocates of human security from below, however, tend to be as sceptical about criminal violence as they are about state violence; allowing violence only to serve justice, which boils down to the protection of human rights - and human rights only. Hence, the logical plea of Mary Kaldor (chapter 2) to work towards a theory of 'just peace': if the dis- 
tinction between war-related violence and violence in times of peace can no longer be made, the legal distinction between jus in bello and jus in pace can better be lifted. In case of 'just peace', at all times, all types of violence have to be addressed as part of the 'normal' order rather than a part of (temporary) emergency measures. The alternative is that normal life will be defined as a 'permanent emergency situation'. ${ }^{17}$

In failing states new struggles for power emerge from below. In autocracies these struggles have produced a peculiar outcome: one group has won the struggle for accumulating capital and means of coercion, but has not won the struggle for the hearts and minds of sufficient subjects. Therefore, this group can only rule by repression and spreading fear. In the autocratic state scenario the private sector disappears. All social behaviour is subject to public control. Big brother is watching you. Human security from below in these circumstances is about resistance and liberation movements.

Obviously, in the present phase of globalisation self-help groups in (partially) failed states and resistance groups in (partially) autocratic states do not function in isolation. Street gangs are part of global networks of organised crime, mainly related to drug trafficking and prostitution (Standing, 2003; Väyrynen, 2003; Hagedorn, 2005). Dissidents in the former Soviet Union and its satellite states were part of global networks of peace movements (be it, I think, less efficiently organised than the crime scene), and Western secret services. Terrorists are online. With or without media attention, all local conflicts have a wider context, economically, socially and/or politically. Extreme isolationism as in the cases of North Korea or the Amazon Indians is almost impossible. North Korea needs extreme repression, loads of barbed wire and long-range missiles to secure its isolation. In I989, the Amazon Indians found their way to the headquarters of the World Bank to demonstrate against the financing of a huge barrage. Human security initiatives from below always involve global connections. The intensity of third-party involvement, however, can vary substantially because it involves policy choices by these parties.

\section{Is There a Conclusion?}

A basic problem of concepts like human security is that one cannot be against it. (This is true for a range of similar political concepts like 
peacekeeping or conflict prevention.) Saying 'human security' paralyses opposition. How to oppose an argument that says 'these people have a right to live', 'they need our protection', 'immediately', 'tomorrow may be too late'? The problem is in the consequence of such a plea: natural disasters aside, the miserable conditions out of which the referent object has to be rescued are caused by other human beings, and the rescuers are humans too. The need to protect the human security of one group generally implies a threat to the human security of others. A painful paradox occurs, especially when 'human security' legitimates violence and repression.

A human security policy by military and/or police means implies permission to arrest or even kill at least some people, that is, the (supposed) violators of human security. This makes human security a dodgy concept, especially in the hands of great powers and superpowers (Paris, 200I; Slim, 200I; De Wilde, 2006). us President George W. Bush showed himself to be a strong advocate of human security when he promised the peoples of the world that 'All who live in tyranny and hopelessness can know: the United States will not ignore your oppression, or excuse your oppressors. When you stand for your liberty, we will stand with you'. ${ }^{18}$ To avoid or limit potential Machiavellian use of the concept, it becomes crucial how the concept is put into practice.

One way of putting it into practice is unrelated to conceptualising human security. It is about doing it. Examples of this were seen in the small groups trying to protect themselves from direct dangers that were described in part III of this book. But should we analyse bottom-up self-help initiatives in terms of human security? Again, the use of violence is a threshold beyond which a human security perspective becomes obscure; as soon as these self-help groups apply violence as part of their survival strategy, the distinction from traditional mafias, traditional guerrilla movements or terrorist organisations gets blurred. How to analyse the evolution of the P LO, the PKK Or ETA in terms of human security? For their adherents, they will be champions of human security, for their victims, gross offenders. How to analyse gangs in failed states or failed cities? Situations such as peace-building in Afghanistan show the reality of the dilemmas involved: if NATO troops in Uruzgan want to increase the civil-military cooperation and gain the hearts and minds of the local population (whose human security is at stake), they have to turn a blind eye to the vast poppy industry - the best local guarantee for freedom from 
want. So while the Taliban is subject to criminalisation, some local warlords and captains of crime will become allies. Probably structural change of the world economy or fundamental redefinition of illegal drugs is needed to really create freedom from fear and want in such regions. In their absence, third-party interference implies give and take involving difficult moral choices. By linking human security to structural violence (recall its origin in development studies rather than security studies) local self-help groups can easily use its logic for radicalisation and justification of direct violence. Third parties will then be confused rather than helped by an appeal to human security. Still, local groups are well-advised to use this appealing rhetoric, just as President Bush is.

Therefore, for the sake of analysis, a human rights perspective should be preferred to a human security framework. The Human Security Index suffers from the problem that 'security' as such has no positive meaning. It can only refer to the absence of threat (Buzan, Wæver and De Wilde, I998). Defining these threats in terms of human security boils down to using development indicators on the one hand (for which we can already use the Human Development Index) and records of human rights violations on the other hand. In terms of human rights it is possible to define offenders and victims; in case of human security, a puzzle emerges about whose security comes first and what legitimate means to defend or obtain it are.

The more interesting aspect of putting human security concerns into practice is related to the blurring distinction between military, police and intelligence. Can we restructure these organisations in such a way that they serve the societies in which they operate? It seems we have to. But especially for the military and for intelligence, a shift of referent object from the state and its territory to people in general and those in foreign territories in particular is quite fundamental. It is illustrative that the pioneer of human security, Canada, faced with the kind of resistance in Afghanistan has moved back to traditional hard power approaches (Moens, 2007). Yet, other recent experiences show that in the face of the present phase of globalisation, there is only limited room left for traditional military strategic thinking. At best it fills a phase in a conflict cycle. The us occupation of Iraq in 2003 clearly showed the limits of military success. The military success of the coalition that occupied Afghanistan in 200I2002 has shown similar limits. The humanitarian intervention in Somalia in I992-I993 taught the same lesson. If the military wants to 
move beyond its traditional tasks (deterrence by the ability to apply direct violence, and by preserving a dreaded reputation), it has to be trained like police officers, diplomats and development workers. At the same time, police forces and intelligence agencies are increasingly confronted with the flipside of globalisation within their own society. In relation to the Global War on Terrorism, this partly implies a shift of referent object towards the state: privacy rights are under pressure, freedom of movement is restricted, compulsory identification has been moved from the state borders to every street corner and public building. A human security discourse therefore may be necessary to counterbalance militarisation of police and intelligence, and to stimulate socialisation of the military.

In the end, there is no conclusion: arguing human security against state security makes sense if states have narrow perceptions of themselves; arguing human security against military security makes sense if troops lose sight of their peace-building tasks; arguing human security against economic security makes sense if corporations think of profit only. It is a strong discourse in favour of the oppressed. It is a dangerous tool, however, in the hands of the strong: it can legitimise dubious interventions and arrests while missing the precision of the human rights discourse. On balance, the discourse must be welcomed and stretched. Just like imprecise concepts such as 'sustainability' and 'good governance' (see chapter I), 'human security' may turn out to be a pivotal concept in a very long struggle to improve the quality of world society.

\section{Notes}

I Sverre Lodgaard (2004: 22) points to a similar link. For contemporary uses of the concept in a context relevant to the human security discourse, see (among others) Farmer, I996; Christie, 1997.

2 Securitisation theory (Buzan, Wæver and De Wilde, I998; Wæver, Buzan and De Wilde, forthcoming) provides a useful framework for analysing this process of position taking.

3 In 2005, the International Labour Organisation (ILO) estimated that I 2.3 million people are victims of forced labour; 9.8 million are exploited by private actors; 2.5 million are exploited by states or rebel military groups (ILO, 2005: IO). Note that the ILO is aware of the human security context of their work (Tapiola, 2005). See also Väyrynen, 2003: I 5-19. 
4 See also: De Wilde, 2004. Be aware that bipolarity is a simplification. Also, during the Cold War there were remarkable differences at the sub-system level: Latin America was almost unipolar, while Asia was tripolar.

5 See the White House's progress report on www.whitehouse.gov/homeland/ progress/.

6 The damage caused by the four hijacked airplanes crashing into the World Trade Centre in New York and the Pentagon in Washington on September I I, $200 \mathrm{I}$ is negligible in societal terms (compare the about 3,000 casualties of 9/I I with the about 43,000 annual traffic-related deaths in the us: www.usatoday.com/news/nation/2003-07-I7-traffic-deaths_x.htm).

7 See e.g. the excellent study about the political impact of the internet in Indonesia by Merlyna Lim (2005).

8 European Court of Human Rights, www.echr.coe.int.

9 In 2006, the Netherlands, for example, was strongly criticised for their inhumane policies towards failed asylum seekers (Council of Europe, Resolution I 483,2006$)$.

Io World Bank, www.worldbank.org/in.

I I See resp. World Bank, www.worldbank.org/pl, and us Census Bureau, www.census.gov.

I 2 One of the Millennium Development Goals is to reduce the percentage of people living in poverty worldwide from 28 per cent in I 990 to I 2.7 per cent in 2015 (http://ddp-ext.worldbank.org/ext/GMIS/home.do?siteId=2).

I3 See: www.ploughshares.ca/libraries/ACRText/ACR-Liberia.html.

I 4 Us Department of Justice's Bureau of Justice Statistics: www.ojp.usdoj.gov/ bjs.

I 5 See: www.darfurgenocide.org.

I 6 Note that the origin of the Leviathan in this reading of state formation differs from Thomas Hobbes' theory: he argues that individuals, out of self-interest (human security concerns?), decide to surrender and pool parts of their original sovereignty in order to escape from the 'state of nature', which he describes in terms that come close to the reports about failed states like Liberia or Sierra Leone (Crisis Group, 2004). Result of pooling sovereignty rights is the creation of a leviathan: a monster with almost unlimited power. But, like Rousseau, Hobbes ( 165 I) offers a social contract theory of sovereignty. In Tilly's reading, the social contract is not the origin of power but a hard-fought victory over it.

I7 For a balanced discussion of the question if war should be treated as a phenomenon with its own legal and moral rules or should be subjected to undifferentiated universal rules, see Neff, 2005.

I 8 G.W. Bush, www.whitehouse.gov/inaugural, 20 January 2005. 


\section{References}

Aalberts, Tanja (2006), Politics of Sovereignty, Amsterdam: Vrije Universiteit.

Anderson, Malcolm and Monica den Boer, Eds. (1994), Policing Across National Boundaries, London: Pinter.

Axworthy, Lloyd, Arthur L. Fallick and Kelly Ross (2005), “The Secure City”, The World Urban Forum 2006, Vancouver Working Group, Discussion Paper, The Liu Institute for Global Issues at the University of British Columbia, 38 pages.

Barber, Benjamin R. (200I; I995), Jihad vs. McWorld: Terrorism's Challenge to Democracy, New York: Ballantine Books.

(Barcelona Report) Study Group on Europe's Security Capabilities (2003), A Human Security Doctrine for Europe: Report of the Barcelona Study Group on Europe's Security Capabilities, Barcelona, September I 5, 2003, available online: http://www.lse.ac.uk/Depts/global/Publications/HumanSecurityDoctrine.pdf; also published in: Glasius, Marlies and Mary Kaldor, Eds. (2006), A Human Security Doctrine for Europe: Project, Principles, Practicalities, London: Routledge, pp. 327-356.

Bayart, Jean-François, Stephen Ellis and Beatrice Hibou (I 999), The Criminalization of the State in Africa, Bloomington: Indiana University Press.

Bigo, Didier ( I994), “The European Internal Security Field: Stakes and Rivalries in a Newly Developing Area of Police Intervention” in Anderson, M. and M. den Boer, I994: I6I-I73.

Boutros Ghali, Boutros, An Agenda for Peace. Preventive Diplomacy, Peacemaking and Peacekeeping, New York: United Nations, I992.

Brauch, Hans Guenther (2005), Threats, Challenges, Vulnerabilities and Risks in Environmental and Human Security, United Nations University Institute for Environment and Human Security (UNU-EHS), Publication Series No. I.

Brocades Zaalberg, Thijs (2005), Soldiers and Civil Power: Supporting or Substituting Civil Authorities in Peace Operations, Amsterdam: Amsterdam University Press.

Buzan, Barry (I991), People, States and Fear: An Agenda for International Security Studies in the Post-Cold War Era, New York, etc.: Harvester Wheatsheaf, (first edition I983).

Buzan, Barry, Ole Wæver and Jaap de Wilde (I998), Security: A New Framework for Analysis, Boulder, co: Lynne Rienner.

Buzan, Barry and Ole Wrever (2003), Regions and Powers: The Structure of International Security, Cambridge: Cambridge University Press.

Chamberlain, William Henry (I947), “U.S.S.R. and U.N.”, Russian Review, Vol. 6, No. 2, pp. 37-43. 
Christie, Daniel J. ( I 997), “Reducing Direct and Structural Violence: The Human Needs Theory", Peace and Conflict: Journal of Peace Psychology, Vol. 3 , No. 4, pp. 315-332.

Clarke, Walter and Jeffrey Herbst (I996), "Somalia and the Future of Humanitarian Intervention", Foreign Affairs, Vol. 75, No. 2, pp. $70-85$.

Crisis Group (2004), Liberia and Sierra Leone: Rebuilding Failed States, Africa Report No. 87, www.crisisgroup.org/home.

Coker, Christopher (200I), Humane Warfare, London: Routledge.

Council of Europe, Resolution I483 (2006), "Policy of Return for Failed Asylum Seekers in the Netherlands", adopted by the Assembly on 26 January 2006 (based on a Report by Rosmarie Zapfl-Helbling, Doc. I074 I, I 5 November 2005), http://assembly.coe.int/Main.asp?link=/Documents/AdoptedText/tao6/ERESI 483 .htm.

De Wilde, Jaap H. (I99I), Saved from Oblivion: Interdependence Theory in the First Half of the 2oth Century. A Study on the Causality between War and Complex Interdependence, Aldershot: Dartmouth.

De Wilde, Jaap H. (I 994), “Geopolitiek zonder grenzen”, Internationale Spectator, Vol. 48, No. I, pp. 7-I I.

De Wilde, Jaap H. (I 996), “De Mondialiserings-Passion”, Internationale Spectator, Vol. 50, No. 7/8, pp. 42I-422.

De Wilde, Jaap H. and Håkan Wiberg, Eds. (I996), Organized Anarchy in Europe: The Role of States and Intergovernmental Organizations, London: I.B. Tauris.

De Wilde, Jaap H. (2004), "Fears into Fences: The Isolationist Pitfalls of European Federalism”, in Guzzini, Stefano and Ditirch Jung, Eds., pp. I 80-I 92

De Wilde, Jaap H. (2006), “Orwellian Risks in European Conflict Prevention Discourse”, Global Society, Vol. 20, No. I, pp. 87-99.

Donnelly, Jack (2002), Universal Human Rights in Theory and Practice, Ithaca, NY: Cornell University Press.

Elias, Norbert (2000 [1939]), The Civilizing Process, New York: Blackwell. Farmer, Paul ( I 996), "On Suffering and Structural Violence: A View from Below”, Daedalus, Vol. I25, pp. 26I-283.

Galtung, Johan (I969), “Violence, Peace, and Peace Research”, Journal of Peace Research, vol. 6, nr. 3, pp. I67-I9I.

Galtung, Johan and Tord Hoivik (I97I), "Structural and Direct Violence: A Note on Operationalization”, Journal of Peace Research, Vol. 8, No. I, pp. 73-76.

Galtung, Johan (I990), “Cultural Violence”, Journal of Peace Research, vol. 27, nr. 3, pp. 29I-305.

Græger, Nina and Dan Smith, Eds. (I994), Environment, Poverty, Conflict, Oslo: PRIO Report 2/94. 
Guzzini, Stefano and Ditrich Jung, Eds. (2004), Contemporary Security Analysis and Copenhagen Peace Research, London: Routledge.

Hagedorn, John M. (2005), “The Global Impact of Gangs”, Journal of Contemporary Criminal Justice, Vol. I, No. 2, pp. I 53-I69.

Hobbes, Thomas (165I), edited by Michael Oakeshott (I946), Leviathan: Or the Matter, Forme and Power of a Commonwealth Ecclesiasticall and Civil, Oxford: Basil Blackwell.

Holm, Tor Tanke and Espen Barth Eide, Eds. (2000), Peacebuilding and Police Reform, London: Frank Cass.

Huntington, Samuel P. (1997), The Clash of Civilization and the Remaking of World Order, London: Simon \& Schuster.

Ilo (2005), A Global Alliance Against Forced Labour, Geneva: ILo.

Kaplan, Robert D. (2000), The Coming Anarchy: Shattering the Dreams of the Post Cold War, New York: Vintage Books.

Lim, Merlyna (2005), “@rchipelago Online: The Internet and Political Activism in Indonesia”, Enschede: University of Twente.

Lodgaard, Sverre (2004), "Human Security: Concept and Operation” in: Muller, M and B. de Gaay Fortman, Eds. 2004: 16-38.

Mack, Andrew and Zoe Nielsen, Eds. (2005), The Human Security Report 2005: War and Peace in the $2 I^{\text {st }}$ Century, Oxford: Oxford University Press, for the Human Security Centre, University of British Columbia, Canada.

Moens, Alexander (2007), "Afghanistan en de revolutie in het Canadese buitenlands beleid", Atlantisch Perspectief, Vol. 3 I, No. 4, pp. 3-I I.

Moser, Caroline O.N. (2004), "Urban Violence and Insecurity: An Introductory Roadmap”, Environment \& Urbanization, Vol. I6, No. 2, pp. 3-ı6.

Muller, Marie and Bas de Gaay Fortman, Eds. (2004), From Warfare to Welfare: Human Security in a Southern African Context, Assen: Royal Van Gorcum.

Neff, Stephan C. (2005), War and the Law of Nations: A General History, Cambridge: Cambridge University Press.

Ogata, Sadako, Amartya Sen, et al. (2003), Human Security Now: Final Report of the Commission on Human Security, New York; http://www.humansecurity-chs.org/finalreport.

Paris, Roland (200I), "Human Security: Paradigm Shift or Hot Air?”, International Security, Vol. 26, No. 2, pp. 87-102.

Rietjens, Bas (2006), Civil-Military Cooperation in Response to a Complex Emergency: Just Another Drill?, Enschede: University of Twente.

Rosenau, James N. (1990), Turbulence in World Politics: A Theory of Change and Continuity, New York: Harvester Wheatsheaf.

Scholte, Jan Aart (2000), Globalization: A Critical Introduction, London \& New York: Macmillan \& St. Martin's Press. 
Scott, L.V. and P.D. Jackson, Eds. (2004), Understanding Intelligence in the Twenty-First Century: Journeys in Shadows, London: Routledge.

Siccama, Jan Geert and Rob J. Anderson (I999), "Meer of minder gewapende conflicten na de Koude Oorlog? Een onderzoeksnotitie”, Transaktie, Vol. 28, No. 4, pp. 526-537.

Slim, Hugo (200I), "Violence and Humanitarianism: Moral Paradox and the Protection of Civilians”, Security Dialogue, Vol. 32, No. 3, pp. 325-339.

Standing, André (2003), "The Social Contradictions of Organised Crime on the Cape Flats”, ISS Paper 74, I 6 pages (Institute for Security Studies, Cape Town, South Africa).

Tapiola, Kari (2005), "Human Security and the Role of the ILO", Speech by the Executive Director I LO Geneva for the $50^{\text {th }}$ anniversary of the reopening of I LO Tokyo Office, 27 September 2005, www.ilo.org.

Tilly, Charles (1990), Coercion, Capital, and European States, AD 990-I990, Oxford/Cambridge, MA: Basil Blackwell.

Tilly, Charles (I994), "War Making and State Making as Organized Crime" in John A. Hall, The State: Critical Concepts, London: Routledge, pp. 508-529 (originally in Peter B. Evans, Dietrich Rueschemeyer and Theda Skocpol I 985 , Eds., Bringing the State Back In, pp. I69-I9I).

UNPD - United Nations Development Programme (1994), Human Development Report I 994: New Dimensions of Human Security, UN PD:

http://hdr.undp.org/reports/global/r994/en/

Väyrynen, Raimo (2003), "Illegal Immigration, Human Trafficking, and Organized Crime”, Discussion Paper No. 2003/72, United Nations University, WIDER, $27 \mathrm{pp}$.

Volten, Peter M.E. (I 996), "Power Politics or International Organization in Central and Eastern Europe?” in De Wilde, J.H., and H. Wiberg, Eds., pp. I 83-202.

Webster, Linda and Douglas D. Perkins (200I), "Redressing Structural Violence Against Children: Empowerment-Based Interventions and Research”, in: Christie, Daniel J., Richard V. Wagner and Debora DuNann Winter, Eds., Peace, Conflict, and Violence: Peace Psychology for the $2 I^{\text {st }}$ Century, Upper Saddle River, NJ: Prentice-Hall, pp. 330-340.

Werner, Wouter G. and Jaap H. de Wilde (200I), “The Endurance of Sovereignty”, The European Journal for International Relations, Vol. 7, No. 3, pp. 283-3 I3.

Winslow, Donna (2002), "Strange Bedfellows: NGOs and the Military in Humanitarian Crisis”, International Journal of Peace Studies, Vol. 7, No. 2, pp. 35-55.

Winslow, Donna (2003), Human Security, Inaugural speech, Vrije Universiteit Amsterdam. 
Wrever, Ole, Barry Buzan and Jaap de Wilde (forthcoming), Politics of Security: The Copenhagen School Framework for Analysis, Boulder, co: Lynne Rienner. 


\section{About the Authors}

Eyal Ben-Ari is Professor of Anthropology at the Hebrew University of Jerusalem.

Willy Bruggeman is Chairman of the Belgian Federal Police Board.

Monica den Boer is scientific dean at the Police Academy of the Netherlands, and Professor in Comparative Public Administration, in particular the internationalisation of the police function, Faculty of Social Sciences, Vrije Universiteit Amsterdam, the Netherlands.

Jaap de Wilde is Professor in International Relations and World Politics at the University of Groningen. While editing this volume he was working for the Faculty of Social Sciences, Vrije Universiteit Amsterdam.

Mient Jan Faber is Professor in Human Security in War Situations, Faculty of Social Sciences, Vrije Universiteit, Amsterdam, the Netherlands.

Cyrille Fijnaut is Professor of Comparative and International Criminal Law, Faculty of Law, Tilburg University, the Netherlands.

Mary Kaldor is Professor of Global Governance at the London School of Economics and Political Science.

Walid Salem is Director of the Society of Democracy and Community Development in Jerusalem. 
Joseph L. Soeters is Professor of Management and Organisation Studies at the Netherlands Defence Academy and Tilburg University, the Netherlands.

Jan Terpstra is Associate Professor at the Institute of Criminology and Criminal Justice, Faculty of Law of the Radboud University Nijmegen, the Netherlands. 


\section{Index}

Aalberts, Tanja 226, 250

Abbas, Mahmoud 172

Abdel-Rahman, Asad I 86, 200

Abu Al-Homos, Na'im I 86, 200

Adler, Amy B I 23, I 24

Afghanistan I 5, 28, 32-33, 42, 44, $49,58,78$, I 2 I, I 52-I 53, I 59, 246247,252

- Kabul I09-III, II6, I 22, I 24

Africa I 8, 24, 42, 49, 53, IOI, I49, I 52, 232, 244, 250, 25 I, 252

African Union (AU) 24, I 50

Al Qaeda 30, 33, 55, 60, 64, I 53 , I77

Al-Aqsa Brigades 34, I94

Albania 33, 37, 78, I 54-I 5 5, I 67

Albrecht, Hans-Jörg I03, IO7

Alexander, Yonah 53,67

Algeria 39

Al-Hadi, Ezzat Abed I 87, 200

Al-Hussein, Zeid Ra'ad I 2

Aliyev, Haidar ${ }^{5} 6$

Aliyev, Ilham I 57

Al-Masri, Hani I93, 200

Al-Shomaly, Gibrael I 89, 200

ambidextrous behaviour I4, I09I IO, I 20

- bonding/bridging II3-I20

Amnesty International 54, I32, I46, I 64, 23 I

Anderson, Malcolm 72, 92, 250

Anderson, Rob J 228, 253
Annan, Kofi A Io, I 2, I 7, 54, I 67

Aquinas, Thomas of 26

Arad, Uzi 192

Arafat, Yasser I91, I92, I94-I96, I98

Arbour, Louis 54

Archer, Sarah E I30, I46

Armenia I56, I 59

Asia 22, 42, 53, 104, 200, 232, 249

Augustine 26, 45

Austria 80, 83, 85, 233

Axworthy, Lloyd 59, 68, 243, 250

Azerbaijan I 56, I 59, I76

B'Tselem 34, I40

Ba'ath Party 39

Bacevich, Andrew J I77

Bakker, Inge 213, 22 I

Balkans 42, 68, 73, 79, I 52

Baltic states 80

Bangladesh 27, I74

Bar, Net I45, I 46

Barak, Ehud 192

Barber, Benjamin R 235, 250

Barcelona Report I 2-I3, I 5, I7, 36, 44, 79, 9 I-92, I03, I06, I 29-I 3 I, I39, I 46, I 5 I, I 53, I 72-I 75, I 80, I 82-I 84, I99, 228, 235, 24I, 250

Baskin, Gershon 199

Batt, Judy 92

Bauman, Zygmunt 206, 219

Bayart, Jean-François 244, 250 
Belgium 52, 80, I I O, I I 7, 229

Bellamy, Alex J I4, I7

Bellier, Irene I 24

Ben-Ari, Eyal I6, I09, I 1 8, I 23, I 27 , I33-I 34, I36, I40, I43, I 45-I 47, 204, 237, 244, 255

Bennett, Janet I 24

Bennett, Milton J I 24

Benson, J Kenneth 2I4, 2 I9

Benyon, John 2I 8-2I9

Berman, Paul I 66

Bigo, Didier 72, 77, 92, 250

Birkinshaw, Julian I 20, I 22

Biscop, Sven 59, 68

Blair, Tony 29

Boli, John 147

Bonner, David 90, 92

Born, Hans 92-95

Bos, Geesje I 20, I 22

Bos-Bakx, Miepke I I I, I 24

Bosnia Herzegovina I 5-I6, 27-28, 37,5 I, 75-76, 78, 94, го4, I 6 , I 24, I 57-I6I

Bosnian Serbs 28

Boutellier, Hans 206, 220

Boutros Ghali, Boutros 23 I, 238, 250

Braithwaite, John 205, 220

Brauch, Hans Guenther 24I, 250

Brazil 203, 232

- Amazon Indians 245

Brenk, Malin I 78

Britt, Thomas W I23-I 24

Brocades Zaalberg, Thijs I4, I 8, 250

Brodeur, Jean-Paul 88, 92

Bruggeman, Willy I3, 47, 255

Bugnion, François 27, 30, 44

Burgess, J Peter 55, 68

Burk, James I32, I 46

Burke, Anthony 25, 32, 35, 44

Burnham, Gilbert 45
Buruma, Ian I 66

Bush, George Herbert W I 54, 205

Bush, George W 23, 28-30, 42, 86, I68-I69, I75, I9I, 246-247, 249

Butler, Richard John I 62, I75

Buzan, Barry 229, 23I, 239, 243, 247-248, 250, 254

Cambodia I 59, I74

Canada Io, I 2, I4, I7, 25, 35-36, 59, $88, \mathrm{I} 77, \mathrm{I} 80, \mathrm{I} 82,232,247,252$

Carlton, David 53,67

Castells, Manuel I 49, I76

Castro, Carl Andrew I 24

Caucasus 42, I 52, 232

Ceadel, Martin I66, I76

Chamberlain, William Henry 229, 250

Chambers, Robert I 8 I

Chechnya 30, 34

Chemical Weapons Convention (CWC) 56

China 2I-23, 232

Chinkin, Christine 35, 44

Christie, Daniel J 68, 248, 25 I, 253

civil society I $5,2 \mathrm{I}, 23-24,45, \mathrm{I} 66$, I68-I70, I76, I78, I 82-I83, I 89, 195-196, I98, 200, 230

Civil-Military Cooperation (CIMIC) I3-I4, I 59, I 74-I75

Clark, Ian 24, 44

Clarke, Walter 238, $25 \mathrm{I}$

Club de Madrid I69-I70, I76

Cohen, Eliot A I77

Cohen, Stanley I46

Coker, Christopher 24I, 25 I

Cold War II, 47, 5I-52, 55, 62, 72, 85 , IOI, I09, I49, I 58, I 75, 227, 23I, 238, 249, 252

- former Warsaw Pact 74 
- post-Cold War 47-48, 227, 250

Collmer, Sabine I 24

Colombia I 52, 244

Connetta, Carl 33, 44

Coolsaet, Rik 49, 57, 59, 68

corruption 48, 62, 73, I02, I 84, I 96

Cortright, David I66, I76

Council of Europe (CoE) 53, 65, 99, 236-237, 249, 25 I

Crawford, Adam 7I, 92, 204, 207, $216,218,220$

Crawford, Neta C 33, 44

criminal law $\mathrm{I} 3,39,50,63-64,80$, 98, I04, 255

Croatia 28, I 56

Cullen, Peter 92

Cushman, Thomas I66, I76

Cyprus 80, I00, I09-II I

Dandeker, Christopher I32, I47

Dayton Agreement 37, 75

De Gaay Fortman, Bas I 8, 252

De Vries, Gijs 86, 89, 93

De Wijk, Rob I 5 5, I76

De Wilde, Jaap H 9, I6-I7, І 68, І 76, 225-226, 229, 23 I, 233-234, 239, 246-25 I, 253-255

Dechesne, Mark II6, I 22

Deitelhoff, Nicole 5I, 68

Delpech, Thérèse 56,68

Democratic Republic of Congo 49, I04, I 37, I 48, I 52, I 75

democratisation I०, 47, 244

- accountability I6, 48, 59, 72-76, 79, 8 5, 87-9I, 2I 2, 2 I 5-2 I 8

- transparency I6, 88, 9I, I32, I96, 2I 6-2I 8

Den Boer, Monica 9, I3, I 5, 7 I-72, 86-88, 9 I-93, 250, 255

Denmark 52, 83 , I IO
Denza, Eileen 97, I06

Der Derian, James 25, 44

Dieben, Diede-Jan 5 I, 68

Donnelly, Jack 25I

Duffield, Mark I 50, I 52-I 53, I76

Duine, J I I 5, I 22

DuNann Winter, Debora 253

Edmondson, Amy I I 8, I 22

Edwards, Adam 205, 2I3, 219-22I

Egypt I79, I92

Eide, Espen Barth I 4, I 8, 24 I, 252

Eiland, Giora 176

Eisenhower, Dwight $\quad$ I74

ElBaradei, Mohamed 56

Elias, Norbert I 24, 234, 25 I

Ellis, Stephan 244,250

Elron, Efrat I09, I I 8, I 23

Erskine, Toni 3 I, 44

Espiel, Hector Gross 199

Ester, Peter $\mathbf{I} 23$

ETA 246

ethnic conflict 48

European Commission 80

European Court of Human Rights

40, 236, 249

European Union (EU) I 2-I 5, I 8, 24, 42, 53, 54, 57, 59, 66, 68, 7 I-94, 97-I07, I 24, I29, I 50-I 5 I, I9I, 204, 226, 228, 232

- Committee of Permanent Representatives (COREPER) 82

- common arrest warrant 54

- Common Foreign and Security Policy (CFSP) I 2, I 5, 73, 75-76, 86-87, 90, 97, IO2-103

- Common Integrated Risk Analysis Model (CIRAM) 83

- Counter Terrorist Task Force (CTTF) 86-87 
- EU Joint Investigation Teams 7I

- EU police missions 74-75

- EUFOR I 5

- Eurojust 88, I05

- European border guard 74, 82-85

- European Civil Protection Agency 57

- European Commission 67, 81, 83, 86, 89, 91 , 93, 104-I06

- European Convention 82

- European Council 57, 77, 8I-83, 93, I00, 102, 104-106

- European Court of Justice $9 \mathrm{I}$

- European Parliament (EP) 67-68, 8 I, 85, 9I-93

- European Security and Defence Policy (ESDP) I 2, I 5, 73, 76, 77, 79, 90, 94-95, 97, 106

- European Security Strategy I3, I 8, $44,73,77,87,98$, I00-IO4, IO

- europeanisation I5,93, I I 5

- Europol 54, 57,65,83,85-88,95, I05

- Force Gendarmerie Européenne 78

- Justice and Home Affairs (JHA) I 5 , 79, 84, 86-88, 94, I06

- Police and Judicial Cooperation in Criminal Matters (PJCC) I 5, 97, I06

- police missions 75-79, 84, 94, I04

- Second/Third Pillar I 5, 86, 97-98, I05, 204

- Strategic Committee for Immigration, Frontiers and Asylum (SCIFA) 82

- Strategic Committee for Immigration, Frontiers and Asylum (SCIFA) 82-84

Evans, Gareth 36, 44, I73-I74, I76

Evans, Michael 147

Evans, Peter B 253
Faber, Mient Jan I 6, I49, I 56, I 58 I 59, I65, I67, I7 I, I76, 204, 244, 255

Fallick, Arthur L 243, 250

Farmer, Paul 248, 25I

Fatah I72, I 84, I94

Ferjani, Nader I 86, 200

Fijnaut, Cyrille I3, I 5, 97, 99, I03, I06, I07, 255

Finland 80,83 , Ioo

Finnemore, Martha I32, I47

Former Yugoslav Republic of Macedonia (FYROM) 76, IO4, I 54

France 30, 32, 39, 77-78, 80, 99, I 54, 204, 220, 232

Franken, Robert I64-I65

Frerks, Georg Io, I 8

Fukuyama, Francis I I6, I 23

G-8 53, I49, 232

Gabriel, Richard A II4, I 23

Galbraith, Peter W I 54, I76

Galtung, Johan 227, 240, 25 I-252

Garfield, Richard 45

Garland, David 7I, 93, 206-207, 220

Gause III, Gregory I70, I76

Gaza I7I-I72, I76, I79, I88-I90, I92

Gazit, Nir I27, I43, I46

Germany 22, 29, 52, 80, IO9-III, I I 5, I I 7, I 24, I 68, I 70, 204, 2 I I, 221,232

Gibson, Christina I 20, I 22

Giddens, Anthony 207, 220

Gilmore, William C 92

Ginzburg, Ruti I40, I4I, I47

Glasius, Marlies I7, 44-46, 92, 106, I 46, I75, I99, 250

global governance I 8, 2I-22, 24-45, $48,68,255$

- Commission on Global Governance IO, I 8 
Global War on Terrorism 28, 54, 57, 73, I68, 235, 248

globalisation 9, I I , 2I-22, 24, 49, 52 , 57, 68, 7I, 73, 225-228, 23 I, 233-

235, 239-24I, 245, 247

- role of the media $33,44,48,66$, I 28-I29, I 32-I33, I 40, I 57-I 58, I 77-I 78, I98, 230, 236, 240, 245

- world society 225,248

good governance I0, I6, 74, 90-9I, IO2, 23 I, 248

Goucha, Moufida 200

Gowricharn, Rubin S I I 4, I 22-I 23

Græger, Nina 234, 252

Granovetter, Mark S I I2-II3, II6I I 7, I 23

Gray, Chris Hables I 50, I 52, I 68, I77

Greece 74, 83, 93, I37, I 48

Greene, Owen 91,93

Gregory, Frank 88, 93

Griffin, Stuart I4, I7

Grotius, Hugo 27

Gumbatov, Aliakram I 59

Guzzini, Stefano 25 I-252

Hagedorn, John M 245, 252

Halevy, Nir 123

Hamas 34, 39, I70-I72, I 88, I90I92, I95, I99-200

Hänggi, Heiner 91, 92, 93, 94, 95

Harlow, Carol 90, 94

Hartigan, Richard Shelly 30, 45

$\mathrm{He}, \mathrm{Zi}$ Lin I I9, I 23

Held, David 24, 45

Hellema, Marte $\quad$ I 8

Helsinki Citizens' Assembly (hCa) I 60, I67, I76

Helton, Arthur C I38, I47

Herbst, Jeffrey 238, 25I
Hezbollah I60, I7I-I72, 238

Hibou, Beatrice 244, 250

Hills, Alice 85,94, I 47

Hindu 122

Hobbes, Thomas 249, 252

Holm, Tor Tanke I4, I 8, 24 I, 252

Hopper, Maurice I39, I 47

Hourani, Faisal 200

Howard, Ross I 57, I77

Ho-won, Jeong 177

Huberts, Don 18

Hughes, Gordon 220

Hulieleh, Samir I90, 200

Human Development Index (HDI)

I 4, 239

human rights IO, I2, I4 , I7, 2 I 23 , 26, 28, 30, 32-37, 39, 42-43, 49, 59-60, 64, 67, 80, 85, 90, IO2, I 28, I30, I32-I33, I39, I43, I45-I46, I 49, I 50-I 5 I, I 53, I 58 -I 59, I 63 , I 70, I73, I8 I-I 84, I 86, I90, I95, 226, 23 I, 236, 239, 243-244, 247248

Human Rights Watch 34, 45, 68, I 32, I 54, I77, 23 I

human security

- Amman Roundtable I29, I45-I46

- Commission on Human Security $35,45,47,68, \mathrm{I} 77,252$

- discourse 9-II, 227-228, 230-23I, $233,235,240,248$

- forces 36, 39, I39

- from below 9, II-I2, I6, I 28, I49I 50 , I 55 , I 57-I 58, I 60, I 66, I 72 , I 74, I79, 203, 233, 244

- Human Security Index (HSI) I 4, 239

- lifeline operation I6, I49, I 58 I 59, I6I, I7 I

- operation I $5,35,37-39,43, \mathrm{I} 28$, I39, I 45, I 5 I, I 53, I 5 5, I 59, I6 I, I63, I73-I 74 
- policies 9, I I-I 5, I7, I I 5, I 29, I 45, I 5 I, I 72, 22 5, 227, 230, 244

- Response Force I3, I 5 , I72

- top-down 9, I I-I 2, I 7, I9

- Doctrine I2, I4, I7, 44, 45, 79, 92 , I03, I06, I 46, I 5 I, I 75, I99, 250

- Human Security Network I4 humanitarian organisation I 28, I 46, I 54, I 58

humanitarianism 27, 42

Hungary 80,85

Huntington, Samuel P 235, 252

Hussein, Saddam 167

India 232, 237

Indonesia 249, 252

intelligence/ secret service I I, I3 , 40, 63, 7I-72, 79, 86-89, I30, I 53 , 226, 24I, 243, 247-248

Interchurch Peace Council (I KV) I75 internally displaced person (IDP) I 56-I 57, I 59-I60, I 62

International Atomic Energy Agency (IAEA) 56,68

International Commission on Intervention and Sovereignty 36 International Committee of the Red Cross (ICRC) 44, 65, I3I-I33, I 47, I 64, 230

international community $26,4 \mathrm{I}, 49$ $50,52,56,60,66$, I 5 I, I67, I72I 74, I 80, I95, 204, 230, 238

International Criminal Court (ICC) I $3,50,53,75$

- Rome Statute 50, 60-62 International Criminal Tribunal for Rwanda (ICTR) 50, 65-66 International Criminal Tribunal for the former Yugoslavia (ICTY) 50, $65-66$, I 75
International Labour Organisation (ILO) 248, 252-253

international law го, 21, 29, 30, 49, 52-53, 6I, 63-67, I66, 23 I

- crimes against humanity 26, 49, $50,60,67,185$

- Geneva Conventions 50, 6I, I49

- humanitarian law 22, 42, 60, 66, 80

- Responsibility to Protect 25,36, 4 I, 44, I 5 I, I 55 , I 73, I 76, I 80

International Monetary Fund (IMF) I 49

international order 48 , IOI, IO2 international society $2 \mathrm{I}, 24,48,60$ international system II, 225, 227, 23I, 235

Intifada (First and Second) 34, 44, I 27, I 3 I-I 34, I 39, I 46, I 79, I 84, I 86-199

Iran 22, I 54

Iraq I2, I6, 22-23, 27-28, 32-34, 3739, 42, 45, 49, 78, I I 5, I 20-I 2I, I3 8, I 47, I 53-I 55, I 59, I6I, I66I69, I 7I-I77, 24I, 247

- Baghdad I58-I59, I6I, I76

Irish Republican Army (IRA) 39-4I, 45

Islam 34, 99-I00, I03, I69-I7 I, I75, I 8 I, I 88, I92, I95, I99, 20I

- Muslims 28, 32, I6I-I65, I70

- Shiites I54, I6I

- Sunnis I6I

- Umma 32

Islamic Jihad 34, I70, I92, I95, I99, $20 \mathrm{I}$

Israel I 6, 32, 34, 38, 44-45, 68, I $27-$ I 28, I32-I34, I38-I4O, I43, I45I47, I60, I 70-I 72, I 79, I 84-200, 238 
- humanitarian officers I27-I 28, I 34, I36-I39, I43, I44-I45

- Israel Defence Forces (IDF) I 27 I 29, I3 I-I 34, I 36, I 38-I40, I44I 47

- Likud I92

Italy 78, 80, 99, I IO, I70, 232

Izhak, Schnell 200

Jackson, PD 24I, 253

Jacobson, Philip 40, 45

Janowitz, Morris I I 5 , I 24

Japan 22, 28, I 68, I 80, 232

Jerusalem 30, I35, I37, I40, I46I 47, I 76, I 79, 200-20I, 255

Johnston, Les 208, 220

Jordan I79, I 87

Jung, Ditrich 25 I-252

Just Peace Theory I7, 2I, 35-36, 4I, I72, 230, 244-245

- cosmopolitan law I49, I 5 I

- global justice 47,67

Just War Theory I7, 2I-27, 29, 35 -

$$
36,4 \mathrm{I}-45
$$

- jus ad bellum I3, 2I, 25, 34

- jus in bello I3, 2I, 25, 30-3 I, 34, 37,245

Kaldor, Mary I2-I3, I7, 2I, 23-24, 34, 39-40, 44-46, 92, 106, I46, I 50 -I 52, I 56, I 75-I77, I 80, I 82 I 83, I99, 230, 244, 250, 255

Kammhuber, Stefan I I 8, I 24

Kaplan, Robert D 235, 252

Karremans, Thom I64-165

Kasher, Asa I32, I47

Katseli, Louka T 66, 68

Kaufman, Edy I85, I96, I99

Kaufman-Nunn, Maxime ı86, г89, 200
Keen, David 52,68

Kellogg-Briand pact 23

Kelstrup, Morton 92, 94

Khudhairi, Jamal 45

Klein Goldewijk, Berma Io, I 8

Knoke, David I I9, I 23

Knoops, GGJ 78,94

Kosovo 33-34, 37, 68, 78, I I6, I24, I 48 , I 54-I 55 , I 57, I 59-I60, I 62, I 67, I69, I73-I 74, I 76-I 78

- Independent International Commission on Kosovo 34, 45

Kouwenhoven, Roderik 204, 21 2, 2 I 5,22 I

Krause, Keith I5 I, I77

$\mathrm{Ku}$, Charlotte 9I, 94

Kümmel, Gerhard I 24

Kurdistan I 54, I6I, I67, I77

Kurds 27, I 54

- PKK 246

Kurth, James I 54, I77

Kyrgistan I IO

Landis, Daniel I 24

Langan, John 26, 45

Lange, Hans-Jürgen 204, 220

Latin America I 68, 200, 23 2, 249

law enforcement I $5,2 \mathrm{I}, 30,55,58$, 60, 62-64, 66-67, 7I , 74, 78-79, 84, 88-9I, 95, I39, I49, I 5 I, I73, I94, 2II, 2 I9

- rule of law Iо, 38, 59, 75, 90, го2

- transnationalisation of 7I, 74

League of Nations 23, 53, 54, I66

Lebanon I60, I7I-I72, I 87

Lee, Shin Wha I80, 200

Leezenberg, Michel I 54, I77

Lejeune, Ph 49, 68

Leveau, Rémy 72, 92

Leyden, Joel I34-I35, I37, I 47 
Liberia 5I, 58, 237, 249, 25 I

Lieber, Francis 29-30, 45

Lim, Merlyna 249, 252

Linderman, Gerald F I I 5, I 23

Lister, Stuart 71, 92

Litvinov, Maxim 228

Lodgaard, Sverre Iо, I 8, 248, 252

Loescher, Gil I3 8, I47

Luther, Martin 29

Lutterbeck, Derek 77, 94

Mace, Catriona 76, 94

MachsomWatch I28, I39-I40, I43-

I 45, I 47

Mack, Andrew I69, I77, 228, 235, 239, 252

Madrid bombings, 2004 54, 89

Major, John 205

Mandzić, Nesib I 64

Maymon, Meirav I27, I40, I43, I 46-I 47

Mazen, Abu I9I, I93

McRae, Rob I7-I 8

McVeigh, Tomothy 28

Medicine Sans Frontier (MSF) I63

Mendes, Pierre 32

Méndez, Juan 68

Michnik, Adam I66

Middle East 42, I45-I46, I 49, I 52 , I 68, 232-234, 237-238

migration $24,80,92,232$

militarisation 40, 47, I38-139, 248

military forces $25,26,35,36,43,91$, I 28, I30, 240

Miller, Laura I 45 , I 47

Milosěvić, Slobodan 34, I 54, I 55 , I 67

Mintzberg, Henry I I9-I 20, I 23

Mladić, Ratko I62, I 64

Moelker, René I I 2, I 24
Moens, Alexander 247, 252

Monar, Jörg 80-8I, 83-85, 94

Montenegro I6I

Montjoy, Robert S 2I 4, 220

Morgan, Gareth I43, I44, I47

Morgan, Rod 7I, 94

Morocco II7, 2 I I

Moser, Caroline ON 24I-243, 252

Moss Kanter, Rosabeth I I 5, I 23

Muller, Marie Io, I 8, 252

multilateralism I2, I4, 22, 29, 36, $48,50,56,64,66,77,84,88$, IOI

Naert, Frederik 99, I07

Nagorno-Karabakh I 59

national interest 24,238

nationalism 9, I3, 5 I, 244

Nef, Jorge I 82, 200

Neff, Stephan C 249, 252

Nelson, Nici I 8I, 200

Netanyahu, Binyamin 192

Netherlands IO, I6, 72, 77-78, I06, I IO, I I6, I 59, I 75, 203-206, 208, 2I I, 2I 5, 2I 8, 22 I, 229, 249, 25 I

- Dutchbat I62-I65

- Netherlands Institute for War Documentation (NIOD) I62-I63, I77

- Royal Military Constabulary (KMar) $77-78$

- Royal Netherlands Air Force (RNLAF) IIO

Newburn, Tim 7I, 94, 207, 220

Newman, Janet 205, 220

Ni Aolain, Fionnuala 45

Nielsen, Zoe I69, I77, 228, 235, 239, 252

Nofal, Mamdouh I95, 20I

non-governmental organisation (NGO) I 5, I 8, 24, 33, 52, IO9, I I 5 , I 2I, I30, I37, I48-I49, I95, 236, 253 
Nordic countries 74

North Atlantic Treaty Organisation

(NATO) I 5, 37, 48, 55, 66, 77, I 50,

I 54-I 5 5, I 59, I 6I-I 62, I 67, I 69, $\mathrm{I} 74, \mathrm{I} 78,246$

- International Security Assistence Force (ISAF) IIO-III, II4-I I 5

North Korea 22, 245

Northern Ireland 39, 40, 4I, 45

Norway IO, I4, 83, 87, I IO

Nuhanović, Hasan I63, I65, I75, I77

Nuhanović, Ibro I64

Nuremberg tribunal 23, 50

O'Reilly, Charles I I9, I 23

O'Toole, Laurence J 2I4, 220

Oakeshott, Michael 252

Ogata, Sadako 35, 45, 47, 68, I 50, I77, 228, 252

Omanović, Camila I 64

Organisation for Security and Cooperation in Europe (OSCE) 77, 79, I 50

Organisation for the Prohibition of Chemical Weapons (OPCW) 56

organised crime I3, 25, 35, 47-50, 57-60, 62, 64, 67, 7 I-73, 76, 78, 98-I05, I 50, 244-245

- gangs 52, I49, I 52, 234, 245-246

- transnational 49, 57, 59, 9I, 226

Page, Joseph T I IO, I 24

Palestine I6, 34, 39, 44, I27-I28, I 3 I-I 40, I 42, I 44-I 47, I 70-I 72, I76, I 79-I 80, I 83-20I

- Palestinian Authorities (PA) I7I, I79, I93-196, I98

Palestinian Independent Commission for Citizens Rights I94, I99, 200
Palestinian Red Crescent Society 44

Paoli, Letizia 99, I07

Pape, Robert A I69-I70, I77-I78

Paris, Roland 246, 252

peace

- activism I 58, I65-I69, I96

- building II-I 2, I4, 63, 2I6, 246, 248

- enforcement II, 63, I3 I, 230

- Hague Appeal for Peace 167

- Hague Peace Conferences 230

- indivisible peace 59, 227-230, 233, 234, 236, 238

- keeping II, I4, 37, 63, 77, I09, I 2O-I 2 I, I 3O-I 3 I , 226, 238,246

- movement 23, I66-I68, I96, 245

Peleman, Johan 5I, 68

Perkins, Douglas D 253

Phalet, Karen I I7, I 23

Pierre, Jon 205, 220

PLO I86-I89, I9I-I92, I95, I97I 98,246

Poetker, Joel S I68, I77

Poland 80, 237

police forces $36,54,57,74,82,99$, IO4, 240, 24I , 248

- community policing I83, 206, 208

- multilateral policing $7 \mathrm{I}$

- police cooperation I 5

Poponete, Christina I Io, I 24

Portugal 74,78

poverty 48-49, 60, I 5I-I 52, I93,

234, 237, 249

Pringle, Peter 40,45

Prodi, Romano 86

Raab, Charles D 92

Ramallah I9I, I94, I96, I99-20I

Ramos-Horta, Jose I 66

Razack, Sherene I 2, I 8 
Reagan, Ronald 205

Red Brigades I70, I75

Rietjens, Bas I4, I 8, 252

Riyadh, Lafta 45

Roberts, Les 33, 45

Roché, Sebastian 204, 220

Rojas-Aravena, Francisco 200

Rolt, Francis I77

Rosenau, James N 233, 252

Ross, Kelly I77, 243, 250

Rote Armee Faktion (RAF) I70, I75

Rousseau, Jean-Jacques 249

Rueschemeyer, Dietrich 253

Rumsfeld, Donald 32

Russian Federation 30, 34, I37, I9I, 232, 250

Rwanda 30, 49-5 I, I72, 238

Ryan, Alan 147

Rygbi, Androw I86, 20I

Sahnoun, Mohamed 36, 44, I73I 74, I 76

Said, Yahia 34, 45

Salem, Walid I6, I79, I85, I90-I92, I96, I99-20I, 204, 237, 244, 255

Salmon, Andrew 39-40, 45

Samarah, Adel I 87-I 88, 20I

Samet, Elizabeth D I I 5, I 23

Savage, Paul L II4, I 23

Schenck, Jean-Claude 220

Schengen Information System (S IS) 8 I

Schiff, Ze'er 34, 45, I33, I 47

Schimel, Jeff I I6, I 24

Scholte, Jan Aart 233, 253

Scott, LV 24I, 253

security

- community I56, I72

- comprehensive 59

- global 36,72,90
- internal/external II, I3, 7I-73, 77, 87-88, 90, 97-98, IOO, IO2-IO5, 225-226, 240-24 I, 244

- local security networks I6, 204209, 2I 2-2I9, 237

- military Io, 47, 232-233, 248

- national or state $9,10, \mathrm{I}_{3}, \mathrm{I}_{5}, 22$, I09, I 66, I 83, 225-226, 235, 24024I, 248

- network models 209

- public 37,38

- referent object of IO, 225-226, 229, 233, 246-248

- securitisation 92, 248

- Security Complex Theory 229

- interdependence I85

- societal 239

- zone I 56, I72

self-help I6, 204, 244-246

Sen, Amartya $35,45,47,68$, I 50 , I77, 228, 252

September I I, 200I (nine-eleven) 28, 33, 4I, 49, 52, 55, 56, 58, 65, 86, 88,98, 100, 235, 243, 249

Serbia 28, 34, 37, I 54-I 56, I 58, I60I 65

Shamir, Boas I09, II 8, I 23

Sharansky, Natan 192

Sharon, Ariel $\mathrm{I} 92$

Shatzberg, Ron I 27, I43, I46

Shaw, Martin I49-I 50, I 52, I77

Shea, Jamie I 54, I 55 , I 78

Shearing, Clifford D 208, 220

Shelley, Louise 58, 68

Shils, Edward A I I 5, I 24

Siccama, Jan Geert 228, 253

Sierra Leone 39, 249, $25 \mathrm{I}$

Sigri, Unsal $\mathrm{I} 24$

Sion, Liora I I 6, I 24

Skocpol, Theda 253 
Slim, Hugo 230-23 I, 246, 253

Slovakia 85

Smith, Dan 234, 252

Smith, Hugh I32, I 47

social contract 24, 26, 36, 4I, 249

Soeters, Joseph I4, I09-II3, II6, I I 8, I 20, I 22-I 24, 24 I, 256

Solana, Javier I 2, 73, 79, 86, 90, 94, I02-IO3, I 29

Somalia I 2, I $8,38,49,58,238,247$, $25 \mathrm{I}$

South Africa 203, 244, 253

sovereignty $9, \mathrm{I} 3,24-25,57, \mathrm{I} 73$, 226, 240, 244, 249

Soviet Union 228, 245

Spain 74, 78, 80, 86, 99-100

Sparks, Richard 220

Srebrenica 37, I6I-I65, I72, I75I77

Standing, André 244-245, 253

state

- armed societies 203, 232

- autocracy 240, 245

- failed 38, 42, 73, IOI, I 29, I 53 , I $55,232,243,245$

- national state 22, 60, 236

- no-go areas in cities 232, 234, 238

- repressive II, I6

- rogue 42, 239

- strong/weak I6I, 219, 225, 232

- territorial 236

Stenson, Kevin 205, 220-22I

Stoker, Gerry 219

Sudan 49, 238

- Darfur 230, 238

Sullivan, Robert R 220-22I

Surinam I I 6

Sutcliffe, Kathleen M I I6, I I8, I 24

Swallow, Paul 87,94

Sweden 83
Switzerland 52, 87, I 37, 229

Swyngedouw, Marc I I7, I 23

Taiwan 22, 232

Taliban 33, 58, I 53, 247

Tanercan, Erhan I 24

Tapiola, Kari 248, 253

Taraki, Liza I90, 20I

Taylor, Paul 40, 45

Terpstra, Jan I6, 203-204, 209, 2 I 22I3, 2I 5, 2I9, 22 I, 237, 244, 256 terrorism I $3,32,34,47-50,52-56$, 58-59, 62, 64-65, 67-68, 7 I-74, 8687, 89-90, 97-I05, I I I, I 29, I49, I 5 I, I 53, I68-I 72, I 76, I 86, I 88, I90, I94, I99, 226, 233, 24I, 245246

- counterterrorism 53-54, 86-87, 8890

- nuclear/catastrophic 49, 57, 235

Thatcher, Margaret 205

Thomas, George M I 47

Tilly, Charles 24I, 243, 249, 253

Tokyo tribunal 23

Triandis, Harry C I22, I 24

Trinidad and Tobago 50

Turkey II 7, I 24, 233

Turner Johnson, James 25, 27, 29-3 I, 45

Tushman, Michael L I I9, I 23

Uganda $\quad$ 774

Ukraine 85

United Kingdom (UK) 72, 80, 87, 99, I 3 8, I 54, I 66-I69, I 75, I 78, 204, 218,232

- House of Lords Select Committee on EU 8O-8I, 83, 85, 94

United Nations (UN) IO-I4, I 8, 23, 25-29, 35-37, 45, 49, 50-54, 57, 60, 


$$
\begin{aligned}
& 63,66-67,69,75,79,89, \text { 107, I33, } \\
& \text { I } 37, \text { I } 48 \text {-I } 5 \text { I, I 54-I 57, I 59-I64, } \\
& \text { I 65-I67, I73, I75, I78, I80, I 82, } \\
& \text { I9I, 2OI, 226-227, 230-232, } 237^{-} \\
& \text {238, } 250,253
\end{aligned}
$$

- Counter-Terrorism Committee 55

- General Assembly 50, I 55

- High Level Panel on Threats, Challenges and Change 25,36, 49, 66, 69, I 78

- International Court of Justice I 66

- millennium development goals 249

- Secrutiy Council 27, 29, 50, 55,63, 69, 75, I 49, I 53-I 54, 232

- UN Centre for International Crime Protection 65

- UN International Police Missions 75,77

- UN International Police Task Force (IPTF) 75

- un Mission in the Democratic Republic of Congo (UNMDRC) I37, I 48

- UN Peacekeeping Force in Cyprus (UNFICYP) IIO, II4-II 5

- UN Programme of Action on Small Arms and Light Weapons 57

- UN Protection Force (UNPROFOR) I 6I

- UNDP IO, I8, 35, I80, I82, I93, 200-20I, 227, 236, 253

- UNESCO I80, I99-200

- UNHCR 90, I 57, I60, I78 USA I $2,32-34,38,54,64,75-76,86$, 88-89, IOO, I IO, I I 4-I I 5, I 54, I 59, I66-I69, I75, I89, I9I, 203, 232, 235, 237-238, 246-247, 249

- Abu Ghraib prison 12

- California I76, 237

- Department of Homeland Security 54
- FBI 88

- Guantanamo Bay 30, 54

- national security strategy 42

- Oklahoma bombing 28,4I

Van den Berg, Coen 122

Van der Veen, Hans 177

Van der Vijver, Kees 219, 22 I

Van Eekelen, Willem 72, 95

Van Iterson, Ad I I 3, I 24

Van Kersbergen, Kees 205, 22 I

Van Tongeren, Paul I 59, I66, I 78

Van Waarden, Frans 205, 22 I

Varoglu, Kadir I 24

Väyrynen, Raimo 245, 248, 253

Verhoeven, Juliette I77-I78

Vietnam 34, I I4-I I 5

Vinken, Henk I 23

violence

- criminal 225, 232, 244

- cultural 227, 240

- in/direct $227,235,247-248$

- political 23, I69-I70, 225, 228, 237-24I

- state 226, 244

- structural 227, 230, 247

- urban 24I

- violent humanitarianism $23 \mathrm{I}$

Vitoria, Francisco 27, 42

Volten, Peter ME 229, 253

Wæver, Ole 229, 23I-232, 239, 247248, 250, 254

Wagner, Richard V 253

Walker, Neil 88, 92, 95, I07

Walzer, Michael 2I, 24, 26, 28, 3I, $34-35,45-46$

war

- civil 47, 49, 5 I, 60

- ethnic cleansing 28,34, 36,37, 50, I 54-I 55, I 65, I 67 
- genocide 23, 26, 48-50, 60-62, 67, I 6I-I63, I65, 230

- high intensity conflicts (HIC) 228

- humanitarian intervention 25-26, 28-3 I, 43, I 29, I 53-I 55, I62, I73I 74, 23I, 238, 247

- inner city warfare 244

- interstate I5I, I68, I74

- intrastate $\mathrm{I} 5 \mathrm{I}$

- jihad 30, I69, I99, 201

- liberation war 53, 228

- low intensity conflicts 239

- mercenaries 27, I49

- new wars 23, 24, 26-27, 38, 43, I $50-152$, I 72

- non-intervention principle 27

- of self-defence $26-27,29,37,166$, 203

- private armies 58

- safe haven/area 27, 37, 60, I 54, I 59, I60-I 63

- small arms $48,57,58$, I 5 I

- suicide bombing 34, 39

- symmetric/asymmetric 22, 23, I 55

- virtual/virtuous 25

- warlords 50

- weapons of mass destruction (WMD) 32, 48, 55, 59, 73, 89, IOI, I 5 I

Warshawsky, Michael I89, 20I

Webster, Linda 253

Weick, Karl E I I6, I 18, I 24

Weigel, George 42, 46

Werner, Wouter 226, 253

West Bank I 27, I47, I79, I 88-I90, I 92
Western European Union (WEU) 59, 69

Wheeler, Nicholas 43,46

White, Matthew I 8, 43

Wiberg, Håkan $25 \mathrm{I}$

Wilkinson, Paul 53,67

Williams, Michael 92, 94

Williams, Paul I4, I7

Wilson, Thomas M I 24

Wilson, Woodrow I68

Winslow, Donna I4, I 8, I 8 , I 24, I3O-I3I, I3 8, I45, I48, 228, 24I, 253-254

Wong, Poh-Kam I I9, I 23

Woolbridge, Jamie 79, 95

World Bank Io, I8, I49, I99, 237, 245,249

World Commission on Environment and Development (WCED) IO, I 8

World Development Bank 200

World War I (WWI) 22, 43, I68, 228229, 233

World War II (WWII) 22-23, 28, 32, $43,50,53$, I I 5, I 23, I 24, I 68

Wouters, Jan 99, I07

Wright, Susan I8 I, 200

Wulf, Herbert 38, 46

www.machsomwatch.org. I 48

Yugoslavia 28, 32-33, 39, 49-50, I 37, I 52, I 56, I60-I6I, I67, I69, $\mathrm{I} 74, \mathrm{I} 76$

Zabusky, Stacia E I IO, I 24

Ziogas, Nikos I $38, I_{4} 8$ 


